Gabriel Forato Anhê

\title{
Adaptações coordenadas da função do pâncreas endócrino e da ação da insulina em músculo esquelético contribuem para a regulação da homeostasia glicêmica no período perinatal
}

Tese apresentada ao Instituto de Ciências Bomédicas da Universidade de São Paulo para obtenção do título de Doutor em Ciências pelo Deparatamento de Fisiologia e Biofísica.

São Paulo

2007 
Gabriel Forato Anhê

\section{Adaptações coordenadas da função do pâncreas endócrino e da ação da insulina em músculo esquelético contribuem para a regulação da homeostasia glicêmica no período perinatal}

Tese apresentada ao Instituto de Ciências Bomédicas da Universidade de São Paulo para obtenção do título de Doutor em Ciências pelo Deparatamento de Fisiologia e Biofísica.

Área de concentração: Fisiologia Humana

Orientador: Prof. Dr. Silvana Bordin

São Paulo

2007 
DADOS DE CATALOGAÇÃO NA PUBLICAÇÃO (CIP)

Serviço de Biblioteca e Informação Biomédica do

Instituto de Ciências Biomédicas da Universidade de São Paulo

(c) reprodução total

Anhê, Gabriel Forato.

Adaptações coordenadas da função do pâncreas endócrino e da ação da insulina em músculo esquelético contribuem para a regulação da homeostasia glicêmica no período perinatal / Gabriel Forato Anhê. - São Paulo, 2007.

Orientador: Silvana Auxiliadora Bordin da Silva.

Tese (Doutorado) - Universidade de São Paulo. Instituto de Ciências Biomédicas. Departamento de Fisiologia e Biofísica. Área de concentração: Fisiologia Humana. Linha de pesquisa: Fisiologia endócrina.

Versão do título para o inglês: Coordenated adaptations of endocrine pancreas and skeletal muscle insulin action contribute to the regulation of glycemic homeostasis during the peripartum period.

Descritores: 1. Fisiologia molecular 2. Metabolismo energético 3. Biologia molecular 4. Gravidez 5. Lactação animal 6. Prolactina I. Silva, Silvana Auxiliadora Bordin da II. Universidade de São Paulo. Instituto de Ciências Biomédicas. Programa de Pós-Graduação em Fisiologia Humana. III. Título. 


\section{UNIVERSIDADE DE SÃO PAULO \\ INSTITUTO DE CIÊNCIAS BIOMÉDICAS}

Candidato(a): $\quad$ Gabriel Forato Anhê.

Título da Tese: $\quad$ Adaptações coordenadas da função do pâncreas endócrino e da ação da insulina em músculo esquelético contribuem para a regulação da homeostasia glicêmica no período perinatal.

Orientador(a): $\quad$ Silvana Auxiliadora Bordin da Silva.

A Comissão Julgadora dos trabalhos de Defesa da Tese de Doutorado, em sessão pública realizada a ...................., considerou

\section{( ) Aprovado(a) ( ) Reprovado(a)}

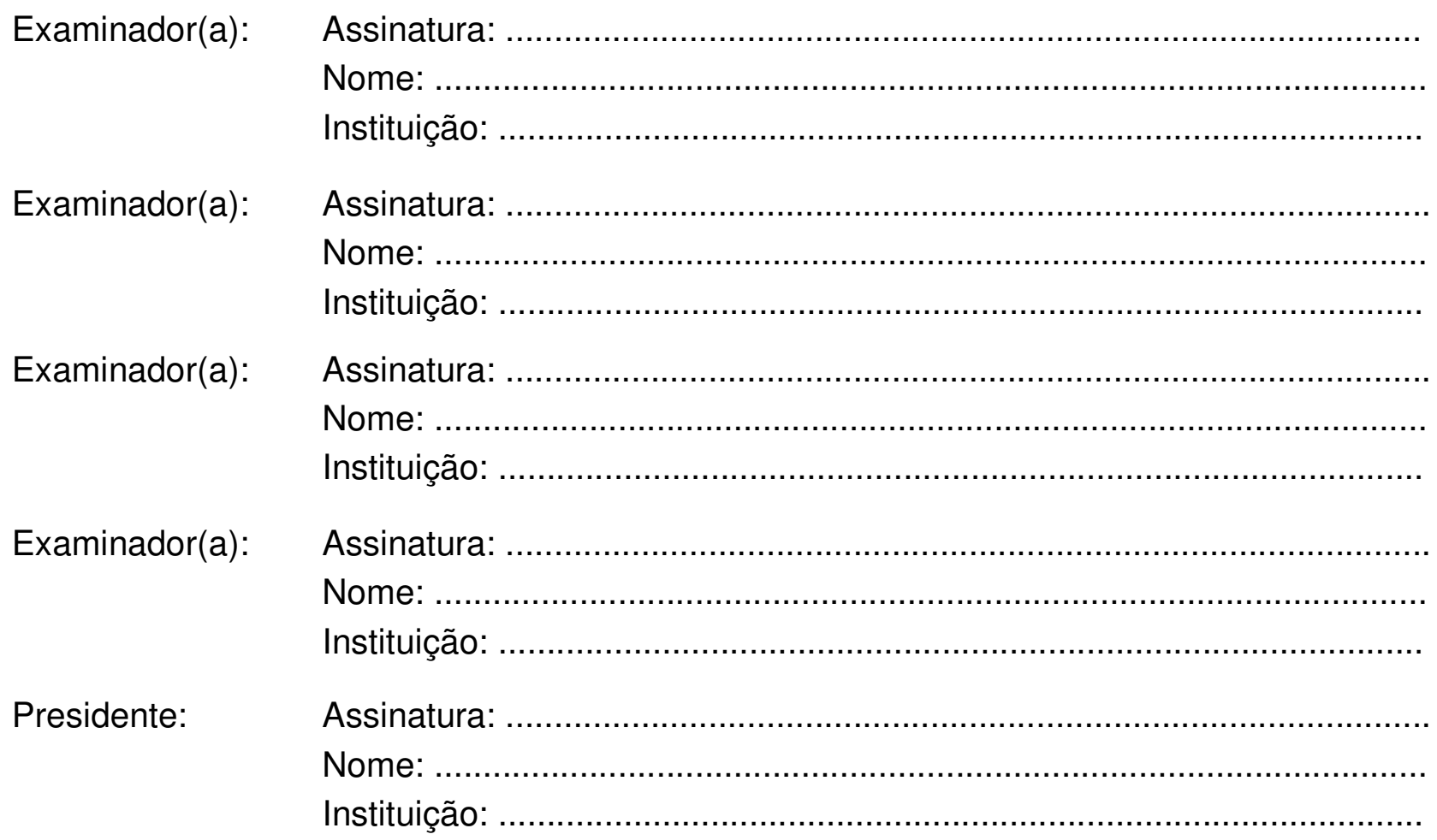




\section{Certificado}

Certificamos que o protocolo registrado sob $\mathrm{t}^{\circ} 063$ nas $1 \mathrm{~s}$. 33 do livo 2 part Uso de rimaís em experimentaço, sob a responsabilidade de Sivana A. Bordin

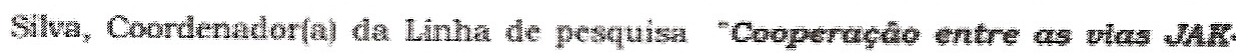

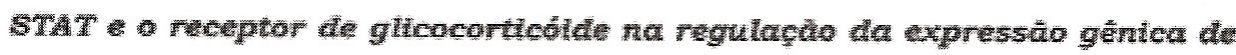
thotas paneredeteas" do qual participou(aram) o(s) alunos Camilo de Lellw

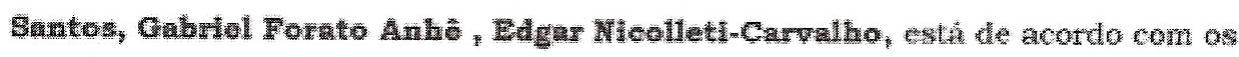

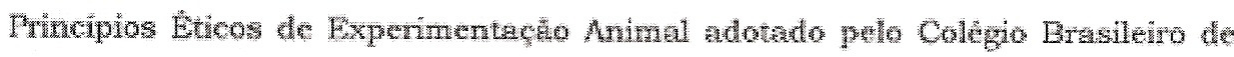
Experimentecho Antmal (COSEA) c ho uprovado pela COMSs EXPERUEWACAO ANMALL (CEEA) em 02.06.2006.

Sho Paulo, 02 de junho de 2006.

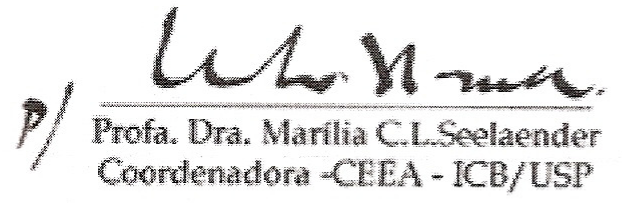

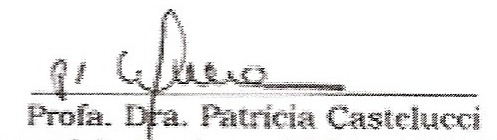
Secretaria suplente CEEA-ICB/USP 


\section{AGRADECIMENTOS}

Agradeço a Professora Silvana pelo constante ensinamento, pelos inúmeros momentos dedicados ao meu aprendizado e pelo espírito sempre questionador e nunca simplificador. Agradeço por ter me mostrado de maneira tão fascinante o infinito universo de tudo aquilo que se pode aprender e o cada vez menor, mas sempre crescente, universo do que sabemos. Por ter sempre me incentivado e desafiado eu serei para sempre grato.

Agradeço aos professores Ubiratan F. Machado, Maria Tereza, Rui Curi, Carla Carvalho, José Cipolla, Andréa Torrão, Fábio Lima, José Bosqueiro e Antonio C Boschero e ao Dr. Sandro Hirabara pelos ensinamentos, apoio e amizade.

Agradeço aos meus amigos de laboratório José Edgar, Luciana Caperuto, Camilo, Tatiane Nogueira, José Luis, Carla Rodrigues, Vinícius, Fernando, Teça e Mayrin pelos momentos agradáveis que me proporcionaram.

Agradeço a todos meus amigos pós-graduandos do Departamento de Fisiologia e Biofísica pelo companheirismo. Agradeço aos funcionários da biblioteca do ICB, dos Biotérios e da Secretaria do Departamento de Fisiologia e Biofísica pelo eficiente serviço prestado ao longo de minha pós-graduação.

Agradeço ao secretário de pós-graduação José Maria Rodrigues por se dedicar incansavelmente a fazer e exigir que se faça o correto, desta maneira servindo e ao mesmo tempo ensinando todos os alunos.

Agradeço a minha mãe, meu pai, meus irmãos e meus avôs e avós por terem servido de exemplo, ao longo de toda minha vida, para tudo aquilo que é correto e justo. Por terem me mostrado o caminho a percorrer e me acompanharem desde o início, eu caminho feliz.

Agradeço a CAPES, CNPq, FAPESP e Universidade de São Paulo pelo apoio financeiro que tornou possível a realização deste estudo. 
I can learn to resist Anything but temptation

I can learn to co-exist With anything but pain

I can learn to compromise Anything but my desires

I can learn to get along With all the things I can't explain

I can learn to resist Anything but frustration

I can learn to persist With anything but aiming low

I can learn to close my eyes To anything but injustice

I can learn to get along With all the things I don't know

Resist, Neil Peart

...con su corno francés y su academia sueca su salsa americana y sus llaves inglesas con todos sus misiles y sus enciclopedias su guerra de galaxias y su saña opulenta con todos sus laureles el norte es el que ordena

pero aquí abajo abajo cerca de las raíces es donde la memoria ningún recuerdo omite y hay quienes se desmueren $y$ hay quienes se desviven $y$ así entre todos logran lo que era un imposible que todo el mundo sepa que el sur también existe 


\section{RESUMO}

Na gravidez, o aumento da resistência à insulina é compensado por alterações morfofuncionais na ilhota pancreática, como o aumento da proliferação e da secreção de insulina. Após o parto ocorre retorno do pâncreas às condições basais e aumento simultâneo da sensibilidade periférica à insulina. Neste trabalho estudamos os mecanismos moleculares responsáveis pelo remodelamento da ilhota no período perinatal. Os resultados mostram que a fosforilação em serina do STAT3 regula a expressão de SERCA2 e assim, modula a primeira fase da secreção de insulina. A fosforilação do STAT3 é dependente da ativação da ERK1/2. No início da lactação, ocorre redução da fosforilação das ERK1/2 devido ao aumento da expressão da fosfatase MKP1. A ação dos glicocorticóides é essencial para este fenômeno, e depende

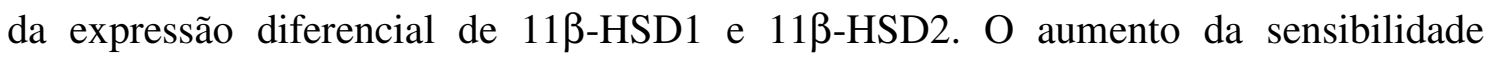
periférica à insulina ocorre especificamente em músculos oxidativos no início da lactação, e depende do aumento da expressão de Glut4, IR, da via IRS2-PI3K-AKT e da diminuição da PTP1B. 


\begin{abstract}
During pregnancy, the increase in insulin resistance is compensated by morfofunctional adaptations of the pancreatic islets, as seen by an increase in cell proliferation and insulin secretion. After delivery, the endocrine pancreas returns to basal conditions, simultaneously to an increase in peripheral insulin sensitivity. In this work we studied the molecular mechanisms involved in islets remodeling during the peripartum period. Our results show that STAT3 serine phosphorylation regulates SERCA2 expression, thus modulating first phase of insulin secretion. STAT3 serine phosphorylation is dependent on ERK1/2 activation. At the beginning of lactation, ERK1/2 phosphorylation is downregulated by the overexpression of the phosphatase MKP1. The action of glucocorticoids is essential in this mechanism, which depends on the differential expression of $11 \beta$-HSD1 and $11 \beta$-HSD2. The increase in peripheral insulin sensitivity occurs specifically on oxidative skeletal muscles, which involves an increase in Glut4 and IR expression, IRS2-PI3K-AKT pathway, and a decrease in PTP1B.
\end{abstract}




\section{SUMÁRIO}

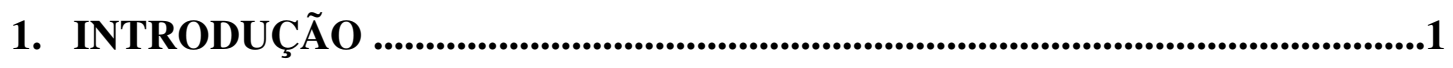

Adaptações do pâncreas endócrino no final da gestação e no início da lactação ................3

Mecanismo de ação da PRL e dos GCs na célula $\beta$ pancreática ......................................4

STAT3 como possível agente envolvido no remodelamento pancreático na transição

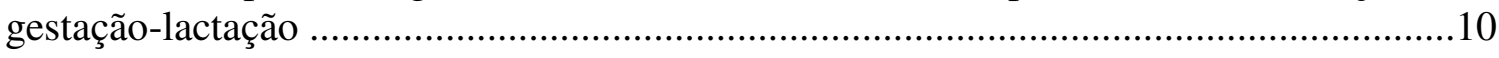

Secreção bifásica de insulina e participação das ATPases de retículo endoplasmático

Alterações na ação da insulina no final da gestação e no início da lactação ....................15

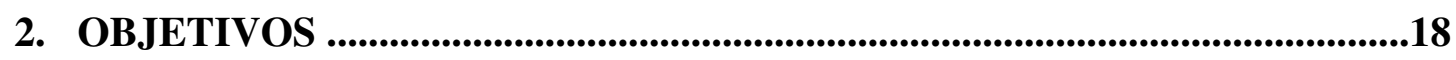

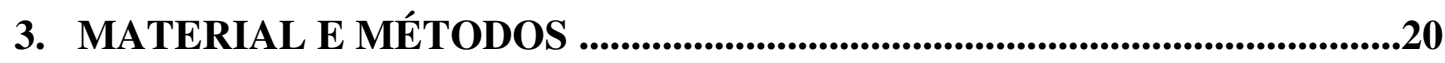

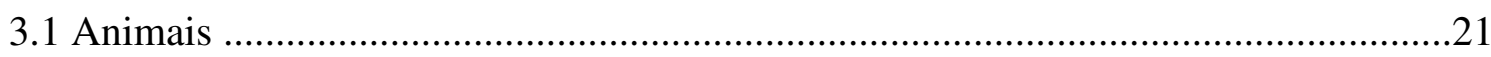

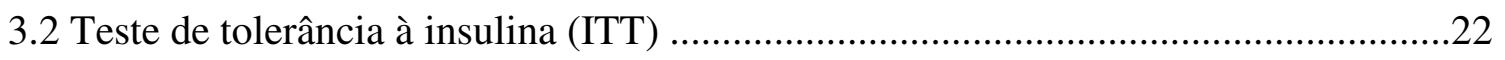

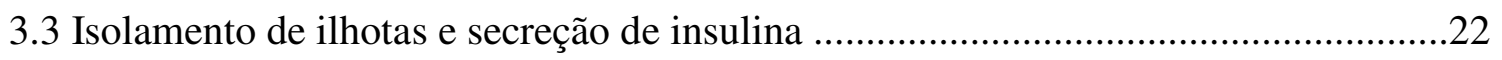

3.4 Cultivo de ilhotas pancreáticas e células RINm5F ..................................................24

3.5 Transfecção de células RINm5F e ilhotas pancreáticas isoladas com oligonucleotídeo

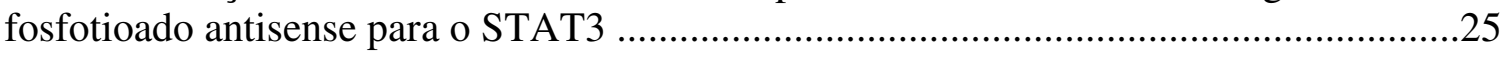

3.6 Extração de proteínas, imunoprecipitação e western blot ...........................................26

3.7 Extração de proteína de membranas totais de músculos solear e plantares ................29

3.8 Metabolismo de glicose em músculo solear isolado ..............................................29

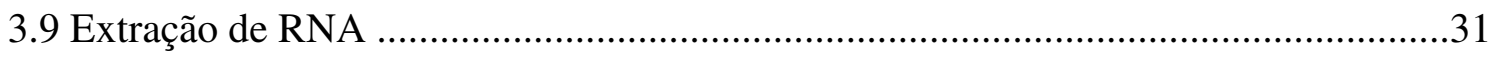

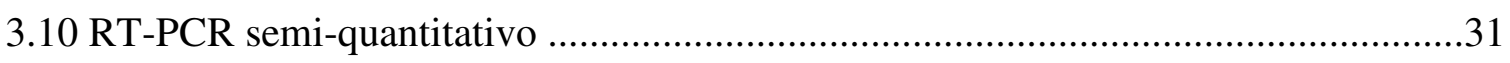

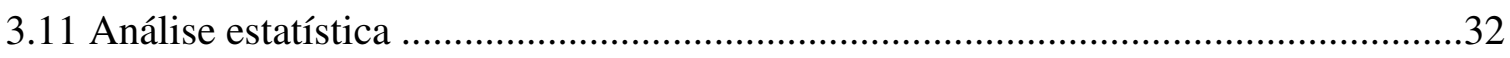

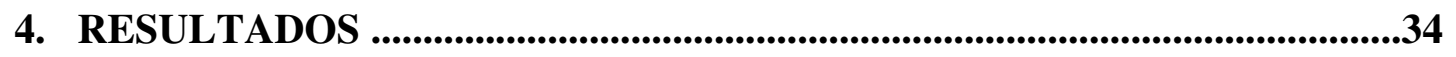

Sensibilidade à insulina avaliada pelo teste de tolerância à insulina (ITT) em ratas durante a

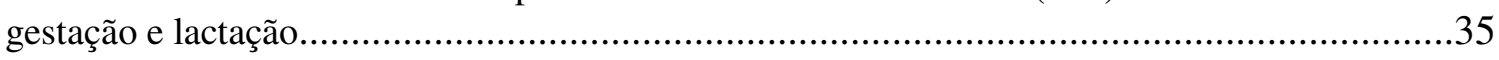

Dinâmica da secreção de insulina de ilhotas isoladas de ratas grávidas e lactantes......................36

Expressão e fosforilação do STAT3 em ilhotas pancreáticas de ratas durante a gestação e lactação. 
Expressão de SERCA2 e SERCA3 em ilhotas pancreáticas de ratas durante a gestação e lactação e a participação da SERCA na primeira fase de secreção de insulina durante a gestação.

Especificidade e eficiência do oligonucleotídeo fosfotioado antisense para o STAT3.

Efeito da PRL sobre a fosforilação em resíduos de serina do STAT3 e a expressão das SERCAs e sua correlação com a secreção de insulina.

Expressão das enzimas 11 $\beta$-HSD1 e 11 $\beta$-HSD2 em ilhotas de ratas grávidas e lactantes...........44

Efeito da DEX e da PRL sobre a expressão e fosforilação do STAT3 em células RINm5F........45

Efeito da DEX e da PRL sobre a expressão SERCA2 em células RINm5F e ilhotas pancreáticas de ratas

Fosforilação e expressão das proteínas das vias da AKT e ERK1/2 em ilhotas pancreáticas de ratas grávidas e lactantes

Efeito da PRL e da DEX na expressão e fosforilação da AKT1 e das ERK 1/2 em células RINm5F

Expressão do mRNA de fosfatases relacionadas à via da ERK 1/2 em ilhotas pancreáticas de ratas L3

Expressão do mRNA de fosfatases relacionadas à via da ERK 1/2 em células RINm5F tratadas com DEX

Captação de glicose, síntese de glicogênio e produção de $\mathrm{CO}_{2}$ no músculo solear de ratas lactantes.

Expressão de GLUT4 no músculo solear e plantares isolados de ratas lactantes.

Expressão e fosforilação em tirosina do receptor de insulina no músculo solear e plantares de ratas lactantes.

Expressão do IRS1 e do IRS2 e fosforilação em tirosina da pp185 no músculo solear e no plantares de ratas lactantes.

Fosforilação em tirosina do IRS1 e do IRS2 e associação com a PI3K no músculo solear de ratas lactantes.

Fosforilação em serina da AKT em músculo solear de ratas lactantes. .60

Expressão de PTP1B em músculo solear e plantares de ratas lactantes. .62

5. DISCUSSÃO

6. CONCLUSÕES 
1. INTRODUÇÃO 


\section{Introdução}

A gravidez é um período em que a mulher é transitoriamente submetida a alterações metabólicas que resultam em um quadro semelhante à síndrome metabólica, mas que geralmente são cuidadosamente reguladas para fornecer um suprimento ideal de substratos para a mãe e para o feto. Observa-se no final da gravidez de ratas uma alta taxa de utilização de glicose pelo concepto, que representa $23 \%$ da taxa de utilização total de glicose pelo organismo materno. Além disso, em resposta ao estímulo pela insulina a placenta ainda demonstra um aumento adicional de $30 \%$ na utilização de glicose (LETURQUE et al., 1986). Este fluxo representativo de glicose direcionado ao concepto é garantido pela resistência à ação da insulina no tecido adiposo (FERRE et al., 1986) e na musculatura composta predominantemente por fibras glicolíticas (por exemplo, o extensor longo dos dedos e o epitroclear) (LETURQUE et al., 1986). De maneira contrária, a musculatura composta predominantemente por fibras oxidativas (por exemplo, o músculo solear) tem uma resposta normal à ação da insulina neste período (LETURQUE et al., 1981). Quando levados em consideração todos os tecidos responsivos à insulina, a captação de glicose diminui de 40 a $60 \%$ durante uma gravidez normal, tanto em humanos como em roedores (HORNNES, 1985; ROSSI et al., 1993).

Sabe-se que os aumentos das concentrações plasmáticas materna de esteróides sexuais, prolactina (PRL), lactogênio placentário (PL) e corticosteróides estão relacionados às alterações acima descritas (BENDER \& CHICKERING, 1985). Certamente a placenta, uma fonte de estrógenos, progesterona e gonadotrofina coriônica, é o órgão que desempenha o papel principal nestas alterações (MURPHY et al., 2006). Além destes hormônios, a unidade feto-placentária produz e secreta, entre 
outros, hormônios como a leptina (AKERMAN, LEI \& RAO, 2002), resistina (LAPPAS et al., 2005), hormônio do crescimento (HENNEN et al., 1985), fatores de crescimento semelhante à insulina I e II (IGFI e II) (FANT, MUNRO \& MOSES, 1986) e hormônio liberador de corticotrofina (CRH) (SHIBASAKI et al, 1982). O desenvolvimento da unidade feto-placentária desencadeia desta maneira, a produção e a liberação para a corrente sanguínea de uma série de hormônios que, salvo situações não fisiológicas, são produzidos em territórios bem definidos do organismo materno. Este fato torna demasiadamente complexa a origem das alterações maternas que se relacionam ao controle da homeostasia glicêmica durante a gestação e a lactação.

\section{Adaptações do pâncreas endócrino no final da gestação e no início da lactação}

Em meados do século passado já se observava a expansão do volume das ilhotas durante a gravidez (HELLMAN, 1960; MARYNISSEN, AERTS \& VAN ASSCHE, 1983), resultado do aumento da taxa de proliferação de células $\beta$ (TEITELMAN, ALPERT \& HANAHAN, 1988) com redução da apoptose (SCAGLIA, SMITH \& BONNER-WEIR, 1995). Em roedores, o aumento da proliferação inicia-se ao redor do décimo dia de gestação, com pico ao redor do décimo quarto dia (PARSONS, BRELJE \& SORENSON, 1992). Porém, o aumento da massa endócrina do pâncreas não é suficiente para desencadear o quadro de hiperinsulinemia característico da gravidez. Em paralelo a proliferação, ocorre o aumento da síntese e secreção de insulina, esta última decorrente da redução do limiar de sensibilidade à glicose (PARSONS, BRELJE \& SORENSON, 1992).

O aumento da sensibilidade à glicose é resultante de inúmeras alterações celulares, dentre as quais, aumento do número dos transportadores de glicose GLUT2 e da atividade e do conteúdo da glicoquinase IV (WEINHAUS, STOUT \& SORENSON, 
1996); do metabolismo de AMPc (WEINHAUS et al., 1998); do acoplamento juncional entre as células $\beta$ (SHERIDAN et al., 1988). Como resultado, estas alterações permitem que as ilhotas secretem mais insulina em condições normais de glicemia e, portanto, compensem a resistência à ação da insulina durante a gravidez.

Da mesma forma que a massa e atividade do pâncreas endócrino aumentam durante a gravidez, ocorre a involução do tecido após o parto (MARYNISSEN, AERTS \& VAN ASSCHE, 1983). Diferente da extensa literatura sobre as alterações da ilhota na gravidez, muito pouco se sabe sobre as alterações da ilhota durante a regressão ao estado não grávida. As poucas evidências relatadas na literatura mostram que: (1) a involução está correlacionada ao aumento da expressão do TGF $\beta 1$, um marcador associado ao processo de apoptose na célula $\beta$ (SCAGLIA, SMITH \& BONNERWEIR, 1995); e, (2) a dexametasona (DEX) contrapõe os efeitos mitogênicos observados tanto no tratamento 'in vitro' com PRL como na gravidez (WEINHAUS et al., 2000). Neste último, os autores propõem que o aumento nos níveis plasmáticos de glicocorticóides (GCs), observados no final da gestação, são os responsáveis pela reversão dos efeitos estimulatórios induzidos pela PRL, inibindo a secreção de insulina e a proliferação celular e estimulando a apoptose.

\section{Mecanismo de ação da PRL e dos GCs na célula $\beta$ pancreática}

As evidências acumuladas nos últimos 30 anos demonstram que o PL e a PRL induzem as mesmas alterações morfofuncionais observadas na gravidez (NIELSEN, 1982; SORENSON et al., 1987; PARSONS, BRELJE \& SORENSON, 1992; DE MAZANCOURT et al., 1994; WEINHAUS, STOUT \& SORENSON, 1996; WEINHAUS et al., 1998; COLARES-BUZZATO et al., 2001; AMARAL et al., 2004). Além destas alterações, que são comuns ao fenótipo de ilhotas de ratas grávidas, o 
tratamento in vitro com PRL promove outras mudanças que explicam o aumento da sensibilidade das células $\beta$ pancreáticas à glicose. Podemos destacar, dentre outras, o aumento do número de canais de $\mathrm{K}^{+}$regulados por ATP e da capacidade da célula $\beta$ de captar $\mathrm{Ca}^{2+}$ (BOSCHERO et al., 1993; CREPALDI et al., 1997), o aumento da síntese de insulina (MARKOFF et al., 1990), o aumento da expressão de e da atividade da glicoquinase (WEINHAUS et al., 2007) e o aumento da expressão do PDX-1 (Pancreatic and Duodenal homeobox 1) (NASIR et al., 2005). O PDX-1 é um fator de transcrição chave na regulação do desenvolvimento pancreático e na diferenciação de células progenitoras em células $\beta$. Este fator de transcrição foi primeiramente descrito como regulador da expressão de insulina e somatostatina. Posteriormente foi demonstrado que o PDX-1 também regula a expressão do GLUT2 e da glicoquinase. Em células $\beta$ adultas, o PDX-1 é também regula a expressão de insulina estimulada por glicose, o que se dá por aumento de sua fosforilação e translocação nuclear (HABENER, KEMP \& THOMAS, 2005).

Essas alterações são, em última análise, o resultado de um ajuste complexo da atividade transcricional das células da ilhota, envolvendo a inibição ou estimulação da síntese de proteínas que medeiam os processos intracelulares. Neste sentido, as alterações da expressão de diversos genes relacionados à sinalização intracelular, transcrição gênica e síntese protéica se encontram alterados tanto pelo tratamento 'in vitro' com PRL (BORDIN et al., 2004a) quanto 'in vivo' durante a gestação (AMARAL et al., 2004).

Além da participação da PRL e dos PLs na adaptação do pâncreas endócrino durante a gestação, já foi demonstrado que o estradiol e a progesterona, apesar de não induzirem um aumento na expressão de glicoquinase em células $\beta$ pancreáticas, promovem um aumento da atividade desta enzima (MAGNATERRA et al., 1997). 
A PRL é um hormônio de caráter pleiotrópico que promove a proliferação e diferenciação de diversos tipos celulares. A ação celular da PRL é iniciada pela sua ligação aos receptores de membrana específicos que pertencem à classe 1 da superfamília dos receptores de citocinas (BOLE-FEYSOT et al., 1998). Após este evento, segue-se a dimerização seqüencial dos domínios intracelulares dos receptores de cadeia longa induzida pelo ligante, seguida da ativação das proteínas JAK2 (CAMPBELL et al., 1994). A JAK2 fosforila resíduos de tirosina das porções intracelulares da cadeia do receptor que, uma vez fosforilados, podem ancorar os STATs (signal transducers and activators of tanscription), fatores transcricionais latentes dispersos no citoplasma celular. O passo seguinte da sinalização envolve a fosforilação do STAT pela JAK2 e formação de dímeros deste fator de transcrição pela afinidade de seus domínios SH2 às tirosinas fosforiladas. Uma vez dimerizados, ocorre a rápida translocação destas proteínas para o núcleo e, finalmente, a modulação da expressão dos genes responsivos aos STATs (DARNELL, 1997).

Dentre as proteínas já descritas como pertencentes à família dos STAT, o STAT1, o STAT3 e o STAT5 foram especialmente relacionados à regulação da sobrevida das células $\beta$ pancreáticas (NIELSEN et al., 2001). Apesar de ser possível a ativação de múltiplas proteínas pertencentes à família do STATs a partir do sinal transmitido pelo receptor de PRL, a geração de camundongos knockout para o STAT5a e o STAT5b mostrou que estas isoformas são a determinantes na ação celular da PRL (LIU et al., 1997; TEGLUND et al., 1998). A ativação do STAT5 em células $\beta$ pancreáticas estimula diretamente a expressão de genes como o do receptor de PRL (GALSGAARD, NIELSEN \& MOLDRUP, 1999), da glicoquinase (WEINHAUS et al., 2001), da ciclina D2 (FRIEDRICHSEN et al., 2003) e da insulina (GALSGAARD et al., 1996). 
O STAT1 por sua vez, não é ativado pela PRL e é conhecido como o principal transmissor do sinal pró-apoptótico gerado por citocinas pró-inflamatórias durante a agressão celular que desencadeia o Diabetes tipo 1. A deleção funcional deste fator de transcrição protege a célula $\beta$ pancreática da ação apoptótica do Interferon- $\gamma$ (INF $\gamma)$ (GYSEMANS et al., 2005; RASCHAERT et al., 2005).

Além dos valores crescentes de PRL circulante durante a gravidez, ratas apresentam aumento de corticosterona no final da gestação (KOMATSU et al., 1998). Após o parto, estes valores permanecem altos até, pelo menos, o $13^{\circ}$ dia de lactação (BERG, DHARMARAJAN \& WADDELL, 2002).

Os GCs têm a capacidade de contrapor as adaptações induzidas pela PRL na ilhota pancreática, em especial o aumento da sensibilidade a glicose e da proliferação celular (WEINHAUS et al., 2000) sendo que a via de sinalização intracelular pela qual os GCs exercem estas funções ainda é desconhecida. Já está bem estabelecido, no entanto, que os GCs potencializam a ativação do STAT5 induzida por PRL na glândula mamária por diversos mecanismos. Em altas concentrações, os GCs induzem a interação do receptor de glicocorticóide (GR) com o STAT5 já ligado ao DNA, o que sugere que o GR funciona como um co-ativador do STAT5 (STOCKLIN et al., 1996; STOCKLIN et al., 1997). Também foi descrito que o GR, quando ativado, sustenta a fosforilação em tirosina do STAT5, prolongando sua atividade transcricional (WYSZOMIERSKI, YEH \& ROSEN, 1999). Estes estudos sugerem que outras vias moduladas positivamente PRL, e não as que culminem na ativação exclusiva do STAT5, devam ser contra-reguladas pelos GCs durante a regressão do pâncreas endócrino ao estado normal no período lactacional.

Neste ponto torna-se importante a informação de que, além da via JAK2/STAT5, a PRL também ativa vias alternativas de sinalização intracelular na célula $\beta$ pancreática. 
Por exemplo, já foi descrito que a PRL promove a ativação das vias PI3K/AKT e da SHC/ERK 1/2 em ilhotas isoladas de ratos neonatos e em ilhotas de ratas adultas grávidas (AMARAL et al, 2003; AMARAL et al., 2004).

Nas células $\beta$ pancreáticas, a AKT pode ser rapidamente ativada não só pela PRL, mas também pela ligação do IGF-1 e do glucagon like peptide 1 (GLP-1) aos seus receptores. A própria insulina é capaz de induzir ativação da AKT em células $\beta$ pancreáticas, o que só acontece em altas concentrações deste hormônio, sugerindo que este efeito deva ocorrer através da ativação de receptores de IGF-I (DICKSON \& RHODES, 2004). A ativação do receptor de IGF-I induz aumento de sua atividade tirosina intrínseca o que, na célula $\beta$ pancreática, resulta em fosforilação de resíduos de tirosina do insulin receptor substrate 2 (IRS2) e ativação da PI3K (WITHERS et al., 1999). A PI3K catalisa a fosforilação de fosfatidil-4-fosfato e fosfatidil-4,5-bifosfato na hidroxila 3', o que gera, respectivamente, fosfatidil-3,4-bifosfato (PIP2) e fosfatidil3,4,5-trifosfato (PIP3). A formação de PIP3 promove a translocação da AKT para a membrana plasmática, onde esta proteína sofre fosforilação na treonina 308, catalisada pela enzima 3-phosphoinositide-dependent protein kinase-1 (PDK-1). Este evento promove a ativação parcial da AKT, que em seguida se autofosforila na serina 473 e se torna completamente ativa (DICKSON et al., 2001). A ativação da AKT por IGF-I e GLP-1 correlaciona-se com o aumento da sobrevida das células $\beta$ pancreáticas (LINGOHR, BUETTNER \& RHODES, 2002; WREDE et al., 2002). Além disto, a expressão aumentada da AKT1 em ilhotas pancreáticas de camundongos trangênicos resulta em um aumento no tamanho e massa das ilhotas e uma melhora na tolerância à glicose em animais com diabetes induzido por injeções de streptozotocina (TUTTEL et al., 2001). 
A participação das ERK 1/2, no entanto, ainda é controversa. A via de ativação das ERK 1/2 compreende a ativação prévia de ERK 1/2 quinase-quinases (proteínas da família Raf) que catalisam a fosforilação das proteínas MEK 1/2. As proteínas MEK 1/2 ativadas catalisam a fosforilação das ERK 1/2 no resíduo da treonina 202 e da tirosina 204 (HUNTER, 1995). Nas células $\beta$ pancreáticas, a ativação das ERK 1/2 resulta na expressão e translocação nuclear do NeuroD, um fator de transcrição essencial para a sobrevivência e desenvolvimento das ilhotas pancreáticas (PETERSEN et al., 2002), e na fosforilação e ativação do PDX-1, o que leva a um aumento de expressão de insulina (KHOO et al., 2003). Há trabalhos que sugerem que a ativação das ERK 1/2 é fundamental para a sobrevivência das células $\beta$ pancreáticas mantidas em cultivo prolongado (PARASKEVAS et al., 1999), e que a ativação destas quinases resulta no aumento de expressão de proteínas anti-apoptóticas (COSTES et al., 2006). Outros sugerem, entretanto, que a ativação das ERK 1/2 é fundamental para a apoptose induzida por citocinas inflamatórias (PAVLOVIC et al., 2000).

Contudo, os altos níveis circulantes de GCs já são detectados a partir do $12^{\circ}$ dia de gestação e atingem valores máximos na última semana antes do parto, coincidindo temporalmente com o ganho de função endócrina do pâncreas. Desta forma, é importante ressaltar que apenas as variações nas concentrações circulantes de GCs durante a transição da gestação para a lactação não são suficientes para explicar o efeito contra-regulador dos GCs sobre as ações da PRL nas células $\beta$ pancreáticas no início da lactação.

Foi estabelecido que a transformação de glicocorticóides hidroxilados na posição $\beta$, catalisada pela enzima $11 \beta$-hidroxiesteróide-desidrogenase (11 $\beta$-HSD), determina o efeito dos GCs em tecidos alvos. Até o momento duas isoformas desta enzima, a $11 \beta$ HSD-1 e a 11ß-HSD-2, foram descritas detalhadamente (OPPERMANN, PERSSON \& 
JÖRNVALL, 1997). A 11ß-HSD-1 age como uma redutase dependente de NADPH em tecidos de roedores e catalisa a conversão de 11-dehidrocorticosterona em corticosterona (LOW et al., 1994). A $11 \beta$-HSD-2 é uma desidrogenase dependente de $\mathrm{NAD}^{+}$de alta afinidade $\left(\mathrm{K}_{\mathrm{m}} \sim 10 \mathrm{nM}\right)$, que, em tecidos de roedores, catalisa a conversão corticosterona para cortisona, sua forma de baixa atividade (Figura 1) (MUNE et al., 1995).

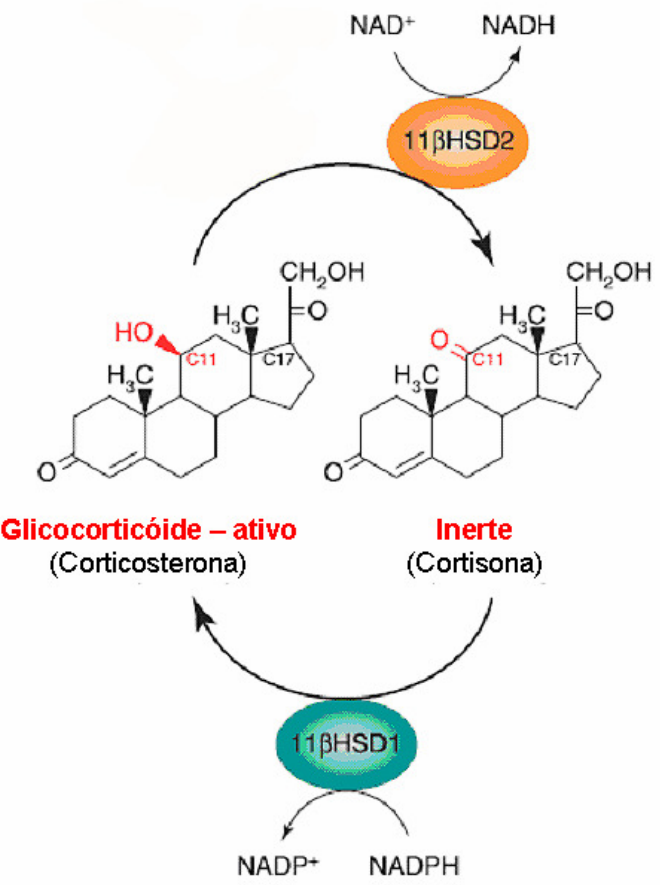

Figura 1. Conversão de corticosterona e cortisona por oxidação ou redução enzimática no carbono 11 (C11) catalisada pelas duas isoformas de $11 \beta$ hidroxiesteróide-desidrogenase $\quad(11 \beta$ HSD).

STAT3 como possível agente envolvido no remodelamento pancreático na transição gestação-lactação

O efeito in vitro da PRL na transcrição de genes em ilhotas pancreáticas de ratas adultas foi previamente estudado em nosso laboratório por análise de macroarray. De maneira geral, este hormônio regula diversos mRNAs potencialmente envolvidos na maturação e no crescimento do pâncreas endócrino, além daqueles já conhecidos e descritos neste capítulo. Os trânscritos modulados pela PRL forma agrupados em seis categorias principais: proliferação e diferenciação celular, transmissão de sinal 
intracelular, fatores de transcrição e coativadores, maquinaria traducional, exocitose mediada pelo cálcio e resposta imune. Neste mesmo estudo também se observou que a PRL reduz a expressão de genes que codificam proteínas pró-apoptóticas (BORDIN et al., 2004a).

A análise por macroarray dos genes modulados na ilhota pancreática de ratas no final da gestação foi realizada na mesma plataforma na qual se estudou os efeitos in vitro da PRL. Esta análise revelou que, de um total de 558 genes, foram detectados 56 genes cujas expressões estavam moduladas positivamente e 3 genes cujas expressões estavam reduzidas (BORDIN et al., 2004b). Vinte e quatro, dentre os 56 genes modulados positivamente durante a gravidez, também tiveram sua expressão aumentada pelo tratamento in vitro com PRL como revelado em nosso estudo prévio (BORDIN et al., 2004a) (Figura 2). Os genes constantes nesta intersecção PRL/Gravidez serviram de base para o presente estudo, que teve como foco a caracterização de algumas proteínas chaves que participam na adaptação do pâncreas endócrino estimulada por este hormônio durante a gestação e também na lactação.

Dentre estes genes comumente modulados durante a gravidez e diretamente pela PRL, o STAT3 foi de especial interesse na medida em que participa do processo de remodelamento da glândula mamária. Clarkson e colaboradores demonstraram que ocorre um aumento de expressão e atividade do STAT3 no tecido mamário de ratas no final da lactação (após o $10^{\circ}$ dia) (CLARKSON et al., 2004). Este evento parece estar relacionado com o aumento da apoptose e a involução deste órgão (CHAPMAN et al., 1999; KRITIKOU et al., 2003; CLARKSON et al., 2004). No entanto, a exemplo de nossos resultados em ilhotas pancreáticas, este grupo de pesquisadores também descreveu um aumento da expressão do STAT3 em tecido mamário no final da 
gestação. Este fenômeno é transiente e retoma valores semelhantes aos de ratas virgens já no $5^{\circ}$ dia após o parto (CLARKSON et al., 2004).

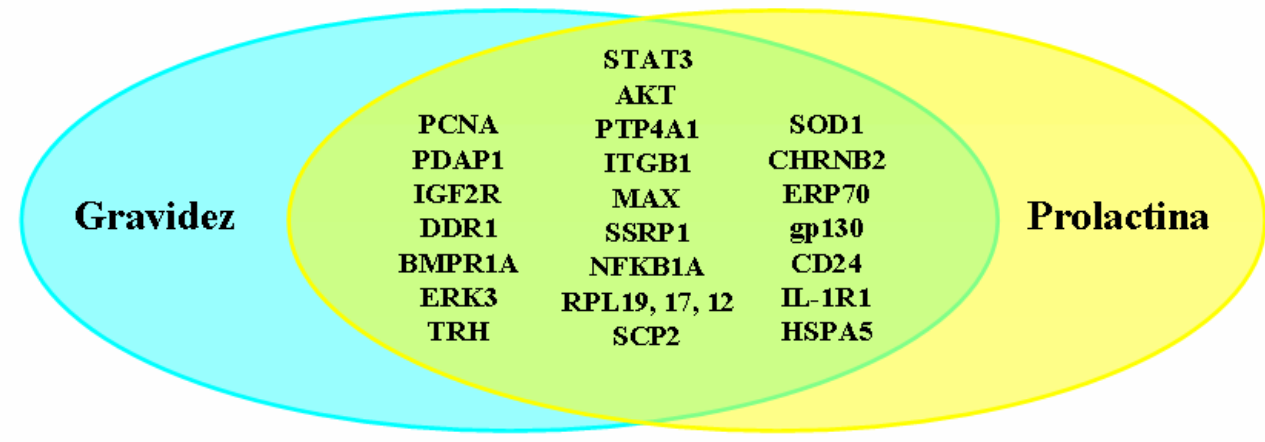

Figura 2: Genes modulados pela PRL e durante a gravidez em ilhotas pancreáticas de ratas. A figura ilustra os genes com modulação comum em ilhotas pancreáticas de ratas em duas situações distintas: gravidez e tratamento in vitro com PRL. Proliferating cell nuclear antigen (PCNA), platelet-derived growth factor associated protein 1 (PDAP1), Insulin-like growth factor 2 receptor (IGF2R), Discoidin domain receptor 1 (DDR1), bone morphogenetic protein receptor 1A (BMPR1A), extracellular signal-regulated kinase 3 (ERK3), Signal transducer and activator of transcription 3 (STAT3), v-akt murine thymoma viral oncogene homolog (AKT), Protein tyrosine phosphatase 4a1 (PTP4A1), Integrin beta 1(ITGB1), Myc-associated factor $X$ (MAX), Structure specific recognition protein 1 (SSRP1), Nuclear factor of kappa light polypeptide gene enhancer in B-cells inhibitor, alpha (NFKB1A), Ribosomal protein L (RPL), Sterol carrier protein 2 (SCP2), Superoxide dismutase 1 (SOD1), Cholinergic receptor, nicotinic, beta polypeptide 2 (CHRNB2), Protein disulfide isomerase related protein (ERP70), glucoprotein 130 (gp130), Interleukin 1 receptor, type I (IL-1R1), Thyrotropin-releasing hormone (TRH), heat shock $70 k D$ protein 5 (HSPA5) e BA-1 antigen (CD24).

Diferentemente do que se observa no tecido mamário no final da lactação, durante o final da gestação e o início da lactação observa-se um aumento de genes relacionados ao estabelecimento do fenótipo secretor e produtor de leite (tais como genes relacionados à síntese e de lipídeos) em paralelo ao aumento do STAT3. Também na transição gestação/lactação, o aumento do STAT3 relaciona-se coma diminuição de fatores pró-inflamatórios e o aumento de fatores antiinflamatórios (CLARKSON et al., 2004).

Recentemente foi demonstrado que a PRL, após tratamento crônico, ativa o STAT3 em linhagens de células derivadas do tecido mamário (NEILSON et al., 2007) 
e, após tratamento agudo, ativa o STAT3 em ilhotas pancreáticas humanas (LABRIOLA et al., 2007). Além disto, foi descrito que ilhotas isoladas de camundongos knockout para o STAT3 apresentam uma redução significativa da primeira fase da secreção de insulina (GOROGAWA et al, 2004).

\section{Secreção bifásica de insulina e participação das ATPases de retículo endoplasmático}

A exposição do pâncreas endócrino a concentrações estimulatórias de glicose desencadeia uma resposta secretora bifásica de insulina pelas células $\beta$ pancreáticas. Esta resposta é caracterizada por uma primeira fase que atinge máxima amplitude após 4 minutos de exposição contínua a glicose, um nadir observado após 6 minutos de exposição e uma subseqüente segunda fase, que exibe valores crescentes e sustentados nos 30 minutos subseqüentes (STRAUB \& SHARP, 2004). Este padrão bifásico foi primeiramente descrito in vivo em humanos (CERASI \& LUFT, 1963) e posteriormente em pâncreas perfundidos de ratos (CURRY, BENNETT \& GRODSKY, 1968a). É importante ressaltar que uma redução na primeira fase de secreção de insulina é comumente observada nos primeiros estágios do desenvolvimento do diabetes tipo 2 e, por isto, é considerado um evento que pode predizer esta doença (AHRÉN, 2005).

O mecanismo conhecido da primeira fase de secreção de insulina prediz que o fechamento de canais de potássio sensíveis ao ATP $\left(\mathrm{K}_{\mathrm{ATP}}\right)$ está envolvido na despolarização da célula $\beta$ pancreática pela glicose, como demonstrado por Ashcroft e colaboradores no início da década de 80 (ASHCROFT, HARRISON \& ASHCROFT, 1984). Após a despolarização ocorre aumento das concentrações intracelulares de $\mathrm{Ca}^{2+}$ que, em parte, origina-se do meio extracelular e atravessa membrana celular por canais de $\mathrm{Ca}^{2+}$ sensíveis à voltagem. $\mathrm{O}$ aumento das concentrações de $\mathrm{Ca}^{2+}$ intracelular 
desencadeia a ativação dos mecanismos de exocitose dos grânulos de insulina (WOLLHEIM \& SHARP, 1981).

Como revisto por Wolheim e Sharp (1981), a glicose induz o aumento da concentração intracelular de $\mathrm{Ca}^{2+}$ por quatro mecanismos combinados: 1) aumento do influxo de $\mathrm{Ca}^{2+}$ a partir do fluido extracelular; 2) diminuição do efluxo de $\mathrm{Ca}^{2+} ; 3$ ) inibição do seqüestro intracelular de $\left.\mathrm{Ca}^{2+}, 4\right)$ mobilização do $\mathrm{Ca}^{2+}$ de estoques intracelulares, presentes nas mitocôndrias e no retículo endoplasmático. A importância do estoque intracelular de $\mathrm{Ca}^{2+}$ e sua capacidade de mobilização pela glicose foram primeiramente demonstradas pela observação de que ilhotas isoladas de animais diabéticos apresentavam defeito na secreção de insulina, apesar da preservação do conteúdo intracelular de insulina e do aumento do influxo de $\mathrm{Ca}^{2+}$ estimulado por glicose (WOLLHEIM \& SHARP, 1981).

A manutenção dos estoques intracelulares de $\mathrm{Ca}^{2+}$ na célula $\beta$ pancreática - e em especial o pool presente no retículo endoplasmático - obedece essencialmente a atividade de proteínas pertencentes à família de $\mathrm{Ca}^{2+}$-ATPases de retículo sarcoendoplasmático (SERCA). A redução da expressão de SERCA2b em células MIN6, mas não a de SERCA3, diminui em $40 \%$ o conteúdo de $\mathrm{Ca}^{2+}$ do retículo endoplasmático (VARADI \& RUTTER, 2002). Em ilhotas pancreáticas expostas à citocinas próinflamatórias observa-se uma depleção dos estoques intracelulares cálcio decorrente da diminuição da expressão de SERCA2 (CARDOZO et al., 2005).

A redução na atividade da SERCA em ilhotas pancreáticas de modelos animais de intolerância glicose tem sido apontada como a causa da secreção deficiente de insulina (MARIE et al., 2001; KULKARNI et al., 2004), inclusive em camundongos $d b / d b$ (ROE et al., 1994). Estes camundongos desenvolvem diabetes tipo 2 em decorrência da ausência de receptores de leptina funcionais, os principais ativadores do 
STAT3 em células $\beta$ (SHAFRIR, 1992; MORTON et al., 1999). É importante destacar que a recuperação da capacidade secretora de ilhotas de animais com receptores de leptina não funcionais é recuperada após a expressão forçada de receptores wild-type e o restabelecimento dos níveis normais de atividade do STAT3 (WANG et al., 1998).

\section{Alterações na ação da insulina no final da gestação e no início da lactação}

A ação da insulina em estimular a captação da glicose em células do tecido muscular e adiposo já é bem conhecida e caracteriza-se por um mecanismo que culmina na translocação de vesículas que contêm moléculas de GLUT4 para a membrana celular. A série de eventos que resulta neste fenômeno começa com a ligação da insulina à cadeia $\alpha$ extracelular do receptor de insulina. Esta ligação transmite um sinal que resulta em uma mudança de conformação e ativação da cadeia $\beta$ transmembrânica, que possui atividade tirosina quinase (SALTIEL \& PESSIN, 2002). Uma vez ativada, a cadeia $\beta$ do receptor de insulina (IR) catalisa sua auto-fosforilação e fosforilação de uma série de proteínas citoplamáticas, ambos em resíduos de tirosina. Dentre as proteínas fosforiladas estão as que pertencem à família dos substratos dos receptores de insulina (IRS). As proteínas IRS fosforiladas em resíduos de tirosina tornam-se aptas a ancorar proteínas que contém um domínio denominado SH2. Dentre estas proteínas encontra-se a subunidade reguladora da PI3K (fosfatidilinositol 3 quinase). A ligação da subunidade reguladora da PI3K resulta na ativação de sua subunidade catalítica e, indiretamente, da AKT (PESSIN \& SALTIEL, 2000). Embora a ativação da AKT não seja o passo imediatamente envolvido no tráfego das vesículas que contém GLUT4, já é consenso na literatura que a AKT é essencial para a translocação do GLUT4 e da captação de glicose (SALTIEL \& PESSIN, 2002). A via de sinalização da insulina é regulada negativamente por proteínas com atividade tirosina fosfatase (PTP) que 
catalisam a desfosforilação do próprio IR e do IRS. As duas PTP mais relevantes que têm sido descritas como reguladoras negativas da transmissão do sinal da insulina em modelos de resistência são as PTP1B e a LAR (STOKER, 2005).

Como demonstrado por Elchebly e colaboradores, a deficiência na expressão de PTP1B resulta no aumento da sensibilidade à insulina e redução na glicemia basal. A fosforilação em tirosina do IR após estímulo agudo de insulina também está aumentada em músculo e fígado destes animais (ELCHEBLY et al., 1999). O mecanismo envolvido depende da ação direta da PTP1B na defosforilação dos resíduos de tirosina no IR (RAMACHANDRAN et al., 1992; SALMEEN et al., 2000). Além de sua ação inibidora sobre o IR, também já foi sugerido que a PTP1B pode defosforilar proteínas ativadas por este receptor em outras etapas da via, tal como o IRS1 (GOLDSTEIN et al., 2000). Um esquema ilustrando a sinalização da insulina aqui descrita e sua regulação pela PTP1B está representado na Figura 3.

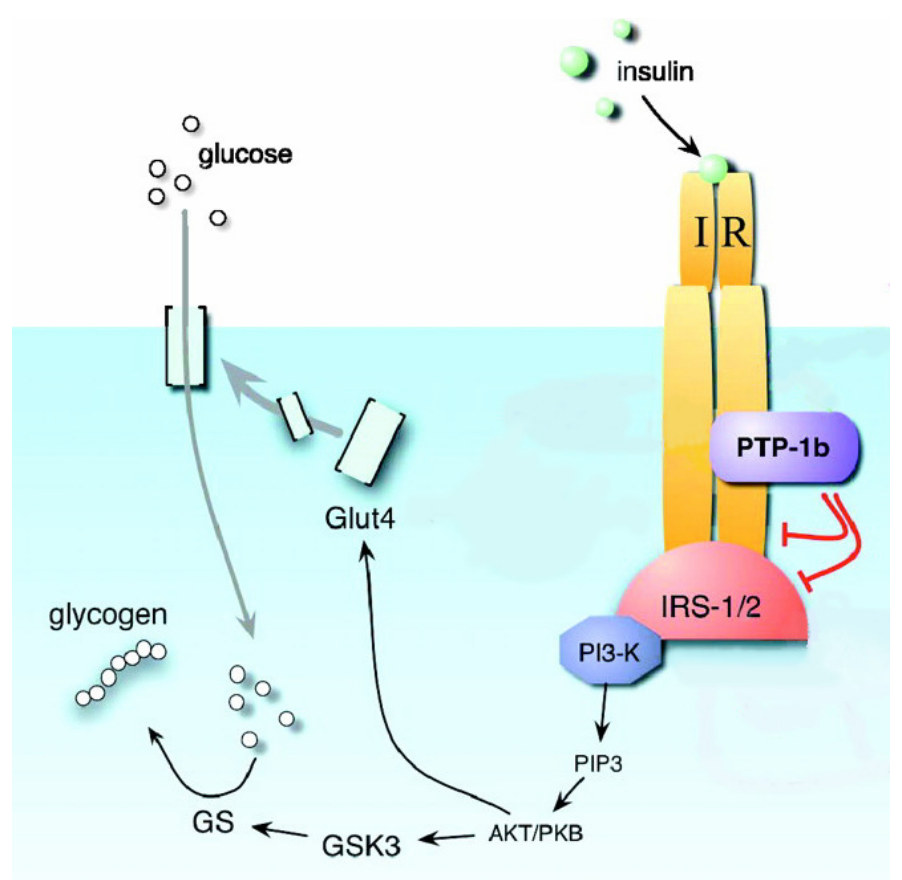

Figura 3. Esquema simplificado da sinalização da insulina e de sua regulação pela PTP1B.

Como mencionado no início deste capítulo, o aporte de glicose para o feto e a placenta no final da gestação é garantido por uma resistência à ação da insulina em 
músculos compostos por fibras glicolíticas e no tecido adiposo. Em ratos, esta resistência se caracteriza pela redução da fosforilação em tirosina do IR e do IRS1 em tecido muscular composto por predominantemente por fibras glicolíticas (SAAD et al., 1997) e redução da fosforilação do IRS1 em tecido adiposo (GONZALEZ et al., 2003). Após o parto, entretanto, a homeostasia glicêmica é mantida mesmo com a alteração brusca do consumo de glicose circulante devido à ausência da placenta e do feto. É intrigante que durante a lactação a rata apresenta hipersensibilidade sistêmica à ação da insulina, demonstrada por técnica do clamp hiperinsulinêmico euglicêmico (BURNOL et al., 1983), mas preserva a resistência em territórios como o tecido adiposo e a músculos compostos por fibras glicolíticas (BURNOL et al., 1987). Desta maneira, o ajuste da homeostasia glicêmica durante a transição gestação/lactação deve decorrer não só pela reversão funcional do órgão produtor de insulina, mas também pela modulação da ação deste hormônio em seus tecidos alvos.

A maioria dos estudos que abordaram o tema da sensibilidade à insulina durante a lactação foi realizada em ratas entre o $11^{\circ}$ e o $13^{\circ}$ dias de lactação. Este período é aceito como o pico da lactação e já foi demonstrado que a glândula mamária desempenha um claro papel nestes altos índices de depuração de glicose (BURNOL et al., 1983; BURNOL et al., 1987). Apesar disto, se observa valores menores de glicemia no período pós-absortivo em ratas já no terceiro dia de lactação (BURNOL et al., 1983). Não se conhece, entretanto, a adaptação precoce que ocorre logo após o parto e caracteriza a transição de um período de resistência a ação da insulina para um período de hipersensibilidade à insulina. 
2. OJETIVOS 


\section{Objetivos}

O presente trabalho teve dois objetivos gerais:

1 - Avaliar o efeito da PRL e a modulação pela DEX nas vias do STAT3, das ERK 1/2

e da AKT em células $\beta$ pancreáticas, relacionando-os às adaptações fisiológicas do pâncreas endócrino durante o período gestacional e lactacional de ratas Wistar.

2 - Avaliar o perfil dinâmico de secreção de insulina em ilhotas de ratas grávidas e lactantes e sua possível relação com o STAT3 e a SERCA2.

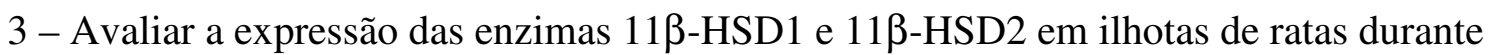
a lactação e a gestação.

4 - Avaliar as alterações na ação metabólica e nas proteínas envolvidas na sinalização celular da insulina durante a transição gestação/lactação em músculos oxidativos e glicolíticos de ratas Wistar. 
3. MATERIAL E MÉTODOS 


\section{Material e Métodos}

\section{Animais}

Foram utilizadas ratas Wistar virgens, grávidas e lactantes, separadas para cruzamento a partir de 2 meses e meio de idade, fornecidas pelo Biotério do Instituto de Ciências Biomédicas da USP (SP), alimentadas com ração padronizada para roedores Nuvilab CR1 (Nuvital Nutrientes S.A.) e água ad libitum e mantidas em ciclo claro/escuro de 12:12 horas e temperatura ambiente de $23^{\circ}$. A verificação do ciclo estral das ratas foi realizada por esfregaço vaginal, por pelo menos duas semanas antes do acasalamento. As ratas com ciclo normal e regular foram então mantidas na proporção de 2 fêmeas por macho por gaiola por um período de 12 horas. Na manhã seguinte, foi feito lavado vaginal para verificação da presença de espermatozóides (indicativo do $1^{\circ}$ dia de gestação). Após o parto as ratas foram mantidas na proporção de uma mãe por oito filhotes lactentes até no máximo 21 dias após o nascimento. Foram utilizadas como controles ratas de mesma idade daquelas destinadas aos cruzamentos (CTL). Desta forma, no momento do sacrifício, a idade média dos animais variou de, aproximadamente, 3 a 4 meses de idade. As ratas foram utilizadas para os experimentos no $19^{\circ}$ dia de gestação (P19), no $3^{\circ}, 8^{\circ}, 13^{\circ}$ e $21^{\circ}$ dias de lactação (respectivamente L3, L8, L13 e L21) e uma semana após o término da lactação (PL7).

Foram observados os princípios éticos na experimentação animal adotados pelo Colégio Brasileiro de Experimentação Animal (COBEA) e pela Comissão de Ética em Experimentação Animal (CEEA) do Instituto de Ciências Biomédicas (protocolo $\mathrm{n}^{\circ}$ 063/33 livro 2). 
2. Teste de tolerância à insulina (ITT)

Para investigar a taxa de desaparecimento da glicose $\left(\mathrm{K}_{\mathrm{itt}}\right)$, ratas CTL, P19, L3, L8, L12, L21 e LP7 foram submetidas ao teste de tolerância à insulina. Após jejum de $12 \mathrm{~h}$, os animais foram anestesiados antes da injeção intraperitoneal de insulina (2UI/kg de peso). Amostras de sangue foram coletadas de uma incisão feita na cauda do animal anestesiado, nos tempos $0,5,10,15,20,25$ e 30 minutos, para determinação da glicemia. A concentração de glicose em sangue total foi realizada por método enzimático/fotométrico utilizando-se um glicosímetro automático Accu-Chek Go ${ }^{\circledR}$ (Roche Diagnóstica Brasil) e fitas apropriadas.

A constante de desaparecimento da glicose foi calculada aplicando-se a fórmula 0,693/t/2. $O t_{1 / 2}$ da glicose foi calculado a partir da inclinação da curva de regressão mínima, durante a fase linear do declínio da concentração de glicose das amostras sucessivas (BONORA et al., 1987).

\section{Isolamento de ilhotas e secreção de insulina}

O isolamento das ilhotas foi realizado pelo método da digestão com colagenase (BORDIN et al., 1995), modificado de Lacy \& Kostianovsky (LACY \& KOSTIANOVSKY, 1967) Os animais CTL, P19 e L3 foram sacrificados por decapitação para retirada de grande quantidade do sangue, que foi seguida de uma incisão abdominal externa. A extremidade duodenal do ducto biliar comum foi ocluída antes da inserção de um cateter através de uma pequena incisão na parte proximal do ducto. Com uma seringa conectada ao cateter injetou-se aproximadamente $15 \mathrm{ml}$ de tampão Hanks (137 mM de $\mathrm{NaCl}, 5.5 \mathrm{mM}$ de $\mathrm{KCl}, 4.5 \mathrm{mM}$ de $\mathrm{NaHCO}_{3}, 0.4 \mathrm{mM}$ de 
$\mathrm{KH}_{2} \mathrm{PO}_{4}, 0.4 \mathrm{mM}$ de $\mathrm{Na}_{2} \mathrm{HPO}_{4}, 0.8 \mathrm{mM}$ de $\mathrm{MgSO}_{4}, 1.5 \mathrm{mM}$ de $\mathrm{CaCl}_{2}, 5.6 \mathrm{mM}$ de glicose, $\mathrm{pH} 7.4)$ contendo colagenase $(0,7 \mathrm{mg} / \mathrm{ml})$ para expansão completa do tecido. Este foi rapidamente removido e transferido para placa de Petri para remoção de gordura, tecido vascular e gânglios linfáticos. A seguir, os pâncreas foram cortados e transferidos para um tubo de $50 \mathrm{ml}$ e incubados em banho-maria a $37^{\circ} \mathrm{C}$ por um período de 25 min. A digestão completa do tecido foi obtida por agitação vigorosa do tubo por cerca de 1 min ou até obtenção de uma mistura de viscosidade homogênea. O conteúdo foi em seguida transferido para um béquer e diluído com solução de Hanks (glicose 5.6 $\mathrm{mM}$ ). As ilhotas foram lavadas 3 vezes com solução de Hanks (glicose $5.6 \mathrm{mM}$ ) para remoção da colagenase e separação parcial por sedimentação. As ilhotas foram coletadas individualmente sob lupa com auxílio de pipeta de vidro estirada.

Os ensaios cumulativos de secreção de insulina foram realizados em ilhotas previamente transfectadas e cultivadas por 36 horas. Após o período de cultivo, grupos de 5 ilhotas forma incubados por 30 minutos em tampão Krebs-Hepes a $37^{\circ} \mathrm{C}(115 \mathrm{mM}$ de $\mathrm{NaCl}, 10 \mathrm{mM}$ de $\mathrm{NaHCO}_{3}, 5 \mathrm{mM}$ de $\mathrm{KCl}, 1 \mathrm{mM}$ de $\mathrm{MgCl}_{2}, 2.5 \mathrm{mM}$ de $\mathrm{CaCl}_{2}, 15$ $\mathrm{mM}$ de Hepes, $\mathrm{pH}$ 7.4) contendo $5.6 \mathrm{mM}$ de glicose, $0,3 \%$ de albumina e saturado de uma mistura de $95 \%$ de $\mathrm{O}_{2}$ e $5 \%$ de $\mathrm{CO}_{2}$. Após este período, esta solução foi substituída por $1 \mathrm{~mL}$ de tampão Krebs-Hepes a $37^{\circ} \mathrm{C}$ saturado de uma mistura de $95 \%$ de $\mathrm{O}_{2}$ e $5 \%$ de $\mathrm{CO}_{2}$, com $0,3 \%$ de albumina e contendo ou 2.8 ou $16.7 \mathrm{mM}$ de glicose. Após 1 hora de incubação, o sobrenadante foi coletado para determinação da concentração de insulina por radioimunoensaio.

Para os ensaios de secreção dinâmica de insulina, grupos de 20 ilhotas de cada condição experimental foram transferidos para câmaras e perfundidas por 20 minutos com tampão Krebs-Hepes a $37^{\circ} \mathrm{C}\left(115 \mathrm{mM}\right.$ de $\mathrm{NaCl}, 10 \mathrm{mM}$ de $\mathrm{NaHCO}_{3}, 5 \mathrm{mM}$ de $\mathrm{KCl}, 1 \mathrm{mM}$ de $\mathrm{MgCl}_{2}, 2.5 \mathrm{mM}$ de $\mathrm{CaCl}_{2}, 15 \mathrm{mM}$ de Hepes, $\mathrm{pH}$ 7.4) contendo $5.6 \mathrm{mM}$ 
de glicose, $0,3 \%$ de albumina e saturado de uma mistura de $95 \%$ de $\mathrm{O}_{2}$ e $5 \%$ de $\mathrm{CO}_{2}$. Um grupo separado de ilhotas isoladas de ratas P19 foi incubado com thapsigargin (inibidor irreversível da SERCA) na concentração final de $5 \mu \mathrm{M}$ por 20 minutos antes do início da perfusão. Após este período de adaptação, as ilhotas foram perfundidas por 10 minutos com mesmo tampão contendo $2.8 \mathrm{mM}$ de glicose. Em seguida, o meio de perfusão foi substituído pelo mesmo tampão Krebs-Hepes a $37^{\circ} \mathrm{C}$ descrito acima contendo $16.7 \mathrm{mM}$ de glicose e as ilhotas foram perfundidas por mais 20 minutos. Após este período, as ilhotas foram perfundidas por mais 10 minutos com mesmo tampão contendo $2.8 \mathrm{mM}$ de glicose. $\mathrm{O}$ efluente foi coletado a cada 1 minuto a partir do vigésimo minuto até o final da perfusão. Neste momento, as ilhotas foram removidas das câmaras e rompidas com o auxílio de um sonicador em tampão apropriado para determinação do conteúdo de insulina (0,2 M de $\mathrm{HCl}$ e $70 \%$ de etanol). A concentração de insulina de cada amostra (secreção e conteúdo) foi determinada por radioimunoensaio. Os resultados foram expressos como a razão da insulina secretada a cada minuto pelo conteúdo de insulina de cada ilhota. Estes experimentos foram realizados em colaboração com o Professor José Roberto Bosqueiro da Universidade Estadual Paulista (UNESP), Bauru, SP e com o professor Antonio Carlos Boschero da Universidade Estadual de Campinas (UNICAMP), Campinas, SP.

\section{Cultivo de ilhotas pancreáticas e células RINm5F}

Ilhotas isoladas ratas Wistar e células de insulinoma de rato da linhagem RINm5F foram mantidas em meio de cultura (RPMI-1640, acrescido de 11,1 mM de glicose, $10 \%$ de soro fetal bovino, $100 \mathrm{U} / \mathrm{ml}$ de penicilina e $0,1 \mathrm{mg} / \mathrm{ml}$ de estreptomicina) em atmosfera com $5 \% \mathrm{CO}_{2}$, a $37^{\circ} \mathrm{C}$. As células $\mathrm{RINm} 5 \mathrm{~F}$ foram usadas entre as passagens 60 e 80 , mantidas em garrafas de plástico de $25 \mathrm{~cm}^{2}$ até atingirem 
confluência de aproximadamente $90 \%$ para serem então repicadas ou usadas nos experimentos.

O tratamento das células RINm5F com PRL (500ng/mL) e DEX (100nM) foi realizado em meio RPMI-1640 sem soro fetal bovino acrescido de 11,1 mM de glicose, $1 \%$ de BSA, $100 \mathrm{U} / \mathrm{ml}$ de penicilina e $0,1 \mathrm{mg} / \mathrm{ml}$ de estreptomicina. Ilhotas tratadas in vitro com PRL e DEX foram mantidas no mesmo meio sem BSA e com $10 \%$ de soro fetal bovino.

5. Transfecção de células RINm5F e ilhotas pancreáticas isoladas com oligonucleotídeo fosfotioado antisense para o STAT3

Antes da transfecção as células RINm5F aderidas e as ilhotas em suspensão (aproximadamente 600 por condição) foram lavadas 4 vezes com solução de KrebsHepes estéril. Para cada transfecção foram diluídos $20 \mu \mathrm{l}$ (de uma solução estoque a 20 $\mu \mathrm{M})$ dos oligonucleotídeos antisense (ASO) e controle (S) em $160 \mu 1$ de meio de cultura Opti-MEM (Invitrogen, EUA); simultaneamente, $1 \mu l$ do reagente de transfecção lipofectamine 2000 (Invitrogen, EUA) foi diluído em $250 \mu$ lo mesmo meio, e estas duas misturas foram mantidas à temperatura ambiente por $10 \mathrm{~min}$. A seguir, os oligonucleotídeos e o reagente de transfecção foram misturados e incubados por 20 min à temperatura ambiente; a mistura foi adicionada às garrafas de células ou às placas contento ilhotas que estavam previamente incubadas com $2,5 \mathrm{ml}$ de Opti-MEM. Esta incubação foi mantida em incubadora de $\mathrm{CO}_{2}$ a $37^{\circ} \mathrm{C}$ por $4 \mathrm{~h}$. Em seguida, adicionou-se às garrafas 2,5 ml de meio RPMI-1640 com albumina, glicose e antibióticos concentrados, a fim de se obter concentração final de $1 \%$ de albumina, $11,1 \mathrm{mM}$ de glicose, $100 \mathrm{U} / \mathrm{ml}$ de penicilina e $0,1 \mathrm{mg} / \mathrm{ml}$ de estreptomicina. Quando devido, PRL em concentração final de $500 \mathrm{ng} / \mathrm{mL}$ também foi adicionada às células. As células e as 
ilhotas foram mantidas por 20 a 24 horas nestas condições, e, a seguir utilizadas para extração de proteína ou para ensaio de secreção de insulina. As sequiências dos oligonucleotídeos utilizados são:

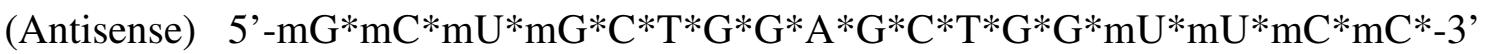

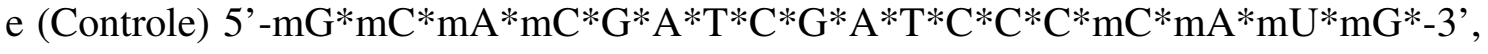
onde ' $m$ ' representa as bases de RNA 2'-O-metoxietil e '*' as bases fosfotioadas.

Os oligos foram desenhados a partir da seqüência do STAT3 de rato depositada em banco de dados público (Genbank, $\mathrm{n}^{\circ}$ de acesso NM_012747), utilizando-se os seguintes parâmetros: (a) pareamento de Watson-Crick em região próxima ao início da tradução; (b) TM igual ou superior a $40^{\circ} \mathrm{C}$; (c) nenhuma homologia significativa com outras seqüências depositadas no Genbank (nucleotídeos ou ESTs - etiquetas de sequiências expressas); (d) terminação 3' contendo nucleotídeo de ligação forte (G ou C). O controle escolhido constitui de um oligo de mesma composição de bases, porém com sequiência aleatória (scrambled), mas que também não apresenta homologia com genes ou ESTs descritos.

\section{Extração de proteínas, imunoprecipitação e western blot}

Antes da extração de proteínas, as células RINm5F e as ilhotas cultivadas foram lavadas duas vezes com solução de Krebs-Hepes à $4^{\circ} \mathrm{C}$ e removidas das garrafas com o uso de rodo de plástico apropriado. Após remoção, as células foram sedimentadas por centrifugação a $1.000 \times \mathrm{g}$ por 10 minutos a $4^{\circ} \mathrm{C}$. Os pellets de células ou ilhotas frescas isoladas de ratas CTL, P19, L3 e L8 foram homogeneizados com o uso de um sonicador (30 segundos em 50\% da potência máxima) em tampão de extração (1\% de SDS, 100 mM de Tris [pH 7,4], $100 \mathrm{mM}$ de pirofosfato de sódio, $100 \mathrm{mM}$ de fluoreto de sódio, 10 mM de EDTA, $100 \mathrm{mM}$ de ortovanadato de sódio e $250 \mathrm{mM}$ de cloreto de sódio), incubados por 10 minutos a $96^{\circ} \mathrm{C}$ e em seguida centrifugados para a remoção do 
material insolúvel $\left(10000 \mathrm{x} g\right.$ por 10 minutos a $\left.4^{\circ} \mathrm{C}\right)$. Parte do sobrenadante foi utilizada para determinação do conteúdo protéico por espectrofotometria com reagente Bradford (Biorad, CA, USA); o restante foi diluído em tampão Laemmli (1:5 v/v) contendo ditiotreitol $100 \mathrm{mM}$, incubados por 10 minutos a $96^{\circ} \mathrm{C}$ e submetido à separação eletroforética em gel de poliacrilamida 6 a 8\% (\%T) com dodecil sulfato de sódio (SDSPAGE) em aparelho para minigel (Mini Protean III, Bio-Rad, CA, USA). No caso da extração de proteínas totais de músculo solear e plantares, os tecidos foram homogeneizados no mesmo tampão $(2 \mathrm{~mL})$ com o uso de um polytron (Kinematica, Suíça) e, em seguida, submetidas ao mesmo procedimento que as amostras de células RINm5F e ilhotas.

Quanto usados para imunoprecipitação, os músculos solear isolados de ratas CTL e L3 foram homogeneizados em $2 \mathrm{~mL}$ de tampão de imunoprecipitação (100 mM de Tris [pH 7,4], $100 \mathrm{mM}$ de pirofosfato de sódio, $100 \mathrm{mM}$ de fluoreto de sódio, $10 \mathrm{mM}$ de EDTA, $100 \mathrm{mM}$ de ortovanadato de sódio, $250 \mathrm{mM}$ de cloreto de sódio, $2 \mathrm{mM}$ de PMSF e 0,1 mg/mL de aprotinina). Após homogeneização, as amostras foram acrescidas de Triton X-100 (concentração final $1 \%$ v/v) e mantidas a $4^{\circ} \mathrm{C}$ por $30 \mathrm{~min}$. Em seguida, as amostras forma centrifugadas para a remoção do material insolúvel (12.000 x g, $4^{\circ} \mathrm{C}$ por 30 minutos). O sobrenadante foi transferido para um novo tubo e uma alíquota foi utilizada para determinação do conteúdo protéico por espectrofotometria com reagente Bradford (Biorad, CA, USA). Após determinação da concentração protéica, volumes contento aproximadamente $500 \mu \mathrm{g}$ de proteínas totais de cada amostra foram incubados com $5 \mu \mathrm{g}$ de anticorpos anti-IRS1 ou anti-IRS2 por 12 horas a $4^{\circ} \mathrm{C}$. A seguir, as amostras foram incubadas com $45 \mu \mathrm{L}$ de proteína A-Sepharose 6MB (Amersham-Pharmacia, Uppsala, Suécia) por 2 horas a $4^{\circ} \mathrm{C}$. As amostras foram então centrifugadas a 12.000 por 15 minutos a $4^{\circ} \mathrm{C}$ e o sobrenadante foi descartado. Os 
pellets de proteína A-Sepharose de cada amostra contendo os complexos antígeno/anticorpo foram lavados três vezes com tampão de lavagem de imunoprcipitado (100 mM de Tris [pH 7,4], $10 \mathrm{mM}$ de EDTA, 2mM de ortovanadato de sódio, $0,5 \% \mathrm{v} / \mathrm{v}$ de Triton $\mathrm{X}-100)$. Estas lavagens foram realizadas a $4^{\circ} \mathrm{C}$ e ao final de cada lavagem o sobrenadante era descartado após centrifugação 12.000 por 5 minutos. Por fim, os pellets foram tratados com tampão Laemmli contendo $100 \mathrm{mM}$ de ditiotreitol (DTT) e incubados por 10 minutos a $96^{\circ} \mathrm{C}$ para redução das proteínas e eluição do conteúdo protéico para o meio líquido. Por fim, os sobrenadantes de tampão Laemmli com as proteínas eluídas da esfera de sefarose foram submetidos à separação eletroforética em gel de poliacrilamida 6,5\% (\%T) com dodecil sulfato de sódio (SDSPAGE) em aparelho para minigel (Mini Protean III, Bio-Rad, CA, USA).

As proteínas presentes nos géis foram transferidas para membranas de nitrocelulose (Bio-Rad, CA, USA) em aparato para transferência elétrica semi-seca (Bio-Rad, CA, USA). As membranas foram posteriormente bloqueadas com uma solução de BSA (ou leite desnatado em pó) a 5\% por 2 horas a temperatura ambiente. Após o bloqueio, as membranas foram incubadas com anticorpos contra STAT3, pSTAT3-Tyr, SERCA2, SERCA3, STAT5, pAKT 1/2/3 Ser, $\alpha$-Tubulina, IR, IRS1, IRS2, PTP1B, fosfo-Tyr (Santa Cruz Biotechnology, CA, USA), pSTAT3-Ser (Cell Signaling, MA, USA), ERK1/2, fosfo-ERK1/2-Thr/Tyr, AKT1 e fosfo-AKT1 (Upstate Biotechnology, USA) por 4 horas a temperatura ambiente ou 12 horas a $4^{\circ} \mathrm{C}$. A seguir, as membranas foram incubadas com anticorpo secundário conjugado à peroxidase (Amershan Pharmacia, UK) e reagentes de detecção do kit de quimioluminescência (ECL, Amershan Pharmacia, UK). As membranas foram então expostas durante tempos variados em filmes de raio-X. Depois de revelados, os filmes foram submetidos à análise de densitometria óptica utilizando o software Scion Image (Scioncorp, USA). 


\section{Extração de proteína de membranas totais de músculos solear e plantares}

Extratos de membrana totais de solear e plantares foram obtidos de acordo com metodologia previamente descrita (OKAMOTO et al., 2004). Os músculos isolados de ratas CTL e L3 foram homogeneizados com um Polytron (Kinematica, Suíça) por 30 segundos a $4^{\circ} \mathrm{C}$ em tampão contendo $10 \mathrm{mM}$ de Tris- $\mathrm{HCl}, 1 \mathrm{mM}$ de EDTA, $250 \mathrm{mM}$ de sacarose $(\mathrm{pH} 7.4)$, e a seguir centrifugados a $700 \mathrm{x} g$ por 10 minutos a $4^{\circ} \mathrm{C}$. Os sobrenadantes foram transferidos para um novo tubo e os pellets foram submetidos ao mesmo procedimento com o intuito de garantir uma maior recuperação de proteínas do tecido homogeneizado. Ao final da repetição do procedimento de extração, os sobrenadantes foram misturados em um novo tubo e submetidos a uma centrifugação de $90.000 \times \mathrm{x} \mathrm{a} 4^{\circ} \mathrm{C}$ por 60 minutos. Os pellets finais contendo a fração protéica obtida de membranas totais foram diluídos em tampão de extração e tratados como amostras de proteínas totais, como descrito na sessão 6 deste capítulo, e usadas para detecção de GLUT4 com anticorpo específico (gentilmente cedido pelo Prof. Ubiratan Fabres Machado, ICB, USP).

\section{Metabolismo de glicose em músculo solear isolado}

Rapidamente após a decapitação, os músculos solear foram removidos de ratas CTL, L3, L8 e L13. Os tecidos foram divididos longitudinalmente em três partes de aproximadamente $30 \mathrm{mg}$ e pré-incubados em tampão Krebs-Hepes com 5,6 mM de glicose, pH 7.4 por 30 minutos a $37^{\circ} \mathrm{C}$ em atmosfera de $95 \%$ de $\mathrm{O}_{2}$ e $5 \%$ de $\mathrm{CO}_{2}$ sob agitação continua a $120 \mathrm{rpm}$. Após este período, os músculos foram transferidos para frascos de vidro contendo o mesmo tampão anterior acrescido de $0.3 \mu \mathrm{Ci} / \mathrm{mL}$ de $\mathrm{D}$-[U- 
$\left.{ }^{14} \mathrm{C}\right]$-glicose e $0.2 \mu \mathrm{Ci} / \mathrm{mL}$ de 2-deoxi-D-[2,6- $\left.{ }^{3} \mathrm{H}\right]$-glicose. Esta incubação, nas mesmas condições que a pré-incubação, durou uma hora e foi realizada na ausência e na presença de insulina $(0.1$ e $10 \mathrm{mU} / \mathrm{mL})$. Um compartimento separado contendo $0,3 \mathrm{~mL}$ de feniletilamina diluída em metanol $(1: 1 \mathrm{v} / \mathrm{v})$ foi adicionado ao tubo de vidro em que foi feita incubação, a fim de absorver o ${ }^{14} \mathrm{CO}_{2}$ para análise de oxidação de D- $\left[{ }^{14} \mathrm{C}\right]-$ glicose. Para determinação da captação inespecífica, algumas amostras foram incubadas com phloretin por 10 minutos antes da incubação com 2-deoxi-D-[2,6- $\left.{ }^{3} \mathrm{H}\right]$-glicose. Após o período de incubação, os músculos foram rapidamente lavados com solução salina a $4^{\circ} \mathrm{C}$, pesados e congelados com $\mathrm{N}_{2}$ líquido. Os meios de incubação contendo os compartimentos com feniletilamina diluída em metanol foram acrescidos de $400 \mu \mathrm{L}$ de $\mathrm{HCl} 10 \mathrm{M}$ e agitados por 30 minutos a $37^{\circ} \mathrm{C}$ e $150 \mathrm{rpm}$. Após este período, a feniletilamina diluída em metanol foi acrescentada em 2,0 mL de líquido de cintilação e submetida à contagem de radiação $\beta$ de ${ }^{14} \mathrm{C}$. Para as análises de síntese de $\left[{ }^{14} \mathrm{C}\right]$ glicogênio e captação de 2-Deoxi-D-[2,6- $\left.{ }^{3} \mathrm{H}\right]$-glicose, os músculos congelados foram incubados com $500 \mu \mathrm{L}$ de $\mathrm{KOH} 1 \mathrm{M}$ por 20 minutos a $70^{\circ} \mathrm{C} ; 150 \mu \mathrm{L}$ desta solução foram misturados a $1,5 \mathrm{~mL}$ de líquido de cintilação e submetidos a contagem de radiação $\beta$ de ${ }^{3} \mathrm{H}$ para cálculo de 2-Deoxi-D-[2,6- $\left.{ }^{3} \mathrm{H}\right]$-glicose captada. Os $350 \mu \mathrm{L}$ restantes da solução inicial de cada músculo foram misturados a $70 \mu \mathrm{L}$ de uma solução com $20 \mathrm{mg} / \mathrm{mL}$ de glicogênio, $70 \mu \mathrm{L}$ de uma solução saturada de $\mathrm{Na}_{2} \mathrm{SO}_{4}$ e $1,2 \mathrm{~mL}$ de etanol absoluto a $20^{\circ} \mathrm{C}$. Esta mistura foi incubada a $20^{\circ} \mathrm{C}$ por 2 horas. A esta incubação seguiu-se uma centrifugação a $2.000 \mathrm{rpm}$ por 20 minutos a $4^{\circ} \mathrm{C}$. O pellet foi diluído em $500 \mu \mathrm{L}$ de água e $150 \mu \mathrm{L}$ desta solução foram misturados a $1,5 \mathrm{~mL}$ de líquido de cintilação e submetidos a contagem de radiação $\beta$ de ${ }^{14} \mathrm{C}$. Estes experimentos foram realizados em colaboração com o Prof. Rui Curi e o Dr. Sandro M. Hirabara, ICB, USP. 


\section{Extração de RNA}

Para a extração dos RNAs totais das ilhotas frescas e cultivadas, das células RINm5F tratadas e/ou trasfectadas e dos músculos solear foi utilizado o reagente Trizol (Invitrogen, EUA), de acordo com as recomendações do fabricante. Os músculos de ratas CTL, L3, L8 e L12 foram homogeneizados no Trizol (100 mg / $1 \mathrm{~mL}$ de Trizol) com o uso de um Polytron (Kinematica, Suíça). As ilhotas (300 / $1 \mathrm{~mL}$ de Trizol) e as células $\left(\sim 10^{8} / 1 \mathrm{~mL}\right.$ de Trizol) foram rompidas por agitação vigorosa em agitador tipo Vortex.

As amostras foram incubadas por 5 min a temperatura ambiente, acrescidos de 0,2 $\mathrm{ml}$ de clorofórmio por $\mathrm{ml}$ de Trizol para desproteinização. O sobrenadante foi separado por centrifugação $\left(12.000 \mathrm{x} \mathrm{g}, 15\right.$ minutos a $\left.4^{\circ} \mathrm{C}\right)$ e o RNA contido na fase aquosa foi transferido para um novo tubo e precipitado com $0,7 \mathrm{~mL}$ de isopropanol $99 \%$ (12.000 x g, 10 minutos a $\left.4^{\circ} \mathrm{C}\right)$. O pellet foi lavado com etanol $75 \%$ e dissolvido com água desionizada previamente tratada com DEPC (dietilpirocarbonato). Uma alíquota de cada RNA obtido foi utilizada para espectrofotometria nos comprimentos de onda de 260 e $280 \mathrm{~nm}$, a fim de se verificar a pureza de cada amostra. Além disto, as amostras foram submetidas à eletroforese em gel de agarose desnaturante a 1,2\%, para análise da integridade do RNA.

\section{RT-PCR semi-quantitativo}

Alíquotas de $1 \mu$ g de cada amostra de RNA foram submetidas à reação de transcrição reversa com primers randômicos. Para isto, foi adicionado em cada amostra tampão da enzima (50 mM de Tris- $\mathrm{HCl} \mathrm{pH}$ 8,3, $75 \mathrm{mM}$ de $\mathrm{KCl}, 3 \mathrm{mM}$ de $\mathrm{MgCl}_{2}$ ), DTT $(10 \mathrm{mM})$, mistura de dNTPs $(0,5 \mathrm{mM}$ cada), primers randômicos $(150 \mathrm{ng})$, inibidor de RNase (40U) e a enzima SuperScript II (200U; Invitrogen, EUA), em volume final de 
$20 \mu 1$. As reações foram incubadas por 50 minutos a $42^{\circ} \mathrm{C}$, seguidas de aquecimento a $70^{\circ} \mathrm{C}$ por 15 minutos para desnaturação da enzima. As condições de amplificação e as seqüências dos primers estão listadas na tabela I. Em todas as reações foram realizadas desnaturações iniciais a $95^{\circ} \mathrm{C}$ por 2 min, seguidas dos ciclos de desnaturação $\left(95^{\circ} \mathrm{C}\right.$, 30s), anelamento (temperaturas listadas na tabela I, tempos de $30 \mathrm{~s})$ e extensão $\left(72^{\circ} \mathrm{C}\right.$, 30s). Cada experimento foi realizado em quadruplicata. Os produtos amplificados foram submetidos à eletroforese em gel de agarose-EtBr e visualizados com iluminação ultravioleta. As imagens foram adquiridas em equipamento de fotovideodocumentação (UVP Bio-lmagin System) para análise densitométrica das bandas obtidas com software apropriado para este fim (Scion Image). A expressão do RNA dos genes de interesse foi normalizada pela expressão dos genes constitutivos RPL37a ou GAPDH. O valor numérico da razão obtida entre a intensidade de expressão do gene de interesse e a intensidade do gene constitutivo representa a intensidade relativa de expressão do gene em questão.

\section{Análise estatística}

Os resultados foram expressos como média \pm erro padrão da média $(\mathrm{EPM})$ e analisados estatisticamente por análise de variância (ANOVA de uma via com pós teste de Tukey, ou duas vias com pós teste de Student, quando apropriado). Em todos os resultados apresentados adotou-se 5\% como limite de significância estatística ( $\mathrm{p}<$ $0,05)$. 
Tabela I. Características dos primers utilizados no PCR semi-quantitativo.

\begin{tabular}{|c|c|c|c|c|}
\hline Gene & Genbank $^{\#}$ & Seqüências (sense, antisense) & $\begin{array}{l}\text { Produto } \\
\text { (pb) }\end{array}$ & $\begin{array}{l}\text { T.A. } \\
\left({ }^{\circ} \mathrm{C}\right)\end{array}$ \\
\hline RPL37a & X4069 & $\begin{array}{l}\text { 5'-CAAGAAGGTCGGGATCGTCG-3' } \\
\text { 5'-ACCAGGCAAGTCTCAGGAGGTG-3' }\end{array}$ & 290 & 57,0 \\
\hline GLUT4 & D28561 & $\begin{array}{l}\text { 5'-GCTGTGCCATCTTGATGACGG-3' } \\
\text { 5'-TGAAGAAGCCAAGCAGGAGGAC-3' }\end{array}$ & 300 & 58,6 \\
\hline MKP-1 & AF357203 & $\begin{array}{l}\text { 5'-CAAGAGCATCCCTGTGGAGGAC-3', } \\
\text { 5'-AGGTAAGCAAGGCAGATGGTGG-3' }\end{array}$ & 159 & 56,7 \\
\hline MKP-2 & NM022199 & $\begin{array}{l}\text { 5'-GAAGAAACGGGTGAGGCTGGAG-3' } \\
\text { 5'-GCTGAAGACGAACTGCGAGGTG-3' }\end{array}$ & 211 & 60,9 \\
\hline MKP-3 & NM053883 & $\begin{array}{l}\text { 5'-TGTCCTGGTGCATTGCTTGG-3' } \\
\text { 5'-GGTGAAGTAGAGCTGCTGTGCG-3' }\end{array}$ & 232 & 57,1 \\
\hline AKT-1 & NM033230 & $\begin{array}{l}\text { 5'-TTCCACCTGTCTCGTGAGCG-3' } \\
\text { 5'-AGTCGTTGTCCTCCAGCACCTC-3' }\end{array}$ & 268 & 59,1 \\
\hline $\mathrm{PP} 2 \mathrm{Ab}$ & X14087 & $\begin{array}{l}\text { 5'-TGGTGCTGGCTACACATTTGG-3' } \\
\text { 5'-GTCACATGAGGCTCTCCACGAC-3' }\end{array}$ & 261 & 55,5 \\
\hline PTEN & NM031606 & $\begin{array}{l}\text { 5'-AAAGCTGGGAAAGGACGGACTG-3' } \\
\text { 5'-AGCTGGCAGACCACAAACTGGG-3' }\end{array}$ & 287 & 55,2 \\
\hline SGK & NM019232 & $\begin{array}{l}\text { 5'-GGAGCCCGAACTTATGAACGC-3' } \\
\text { 5'-AATGCTTCTTCTGCCTTGTGCC-3' }\end{array}$ & 177 & 56,0 \\
\hline SERCA2 & NM017290 & $\begin{array}{l}\text { 5'- CTCTGGGTCAATCTGGTGACGG-3' } \\
\text { 5'- TGCCATTGTCATCGGATACGG-3' }\end{array}$ & 324 & 58,8 \\
\hline GLUT2 & J03145 & $\begin{array}{l}\text { 5'-CATTGCTGGAAGAAGCGTATCAG-3' } \\
\text { 5'-GAGACCTTCTGCTCAGTCGACG-3' }\end{array}$ & 408 & 55,0 \\
\hline SUR1 & AB052294 & $\begin{array}{l}\text { 5'-TTCCACATCCTGGTCACACCG-3' } \\
\text { 5'-AGAAGGAGCGAGGACTTGCCAC-3' }\end{array}$ & 425 & 60,0 \\
\hline $11 \beta-H S D 1$ & NM017080 & $\begin{array}{l}\text { 5'-GTGCGAAGAAGCATGGAGGTC-3' } \\
\text { 5'-CCGAGGACACAGAGAGTGATGG-3' }\end{array}$ & 242 & 56,3 \\
\hline $11 \beta-H S D 2$ & NM017081 & $\begin{array}{l}\text { 5'-TGGCTGCTTCAAGACAGAGGC-3' } \\
\text { 5'-GGGCTAAGGTCAGGCAATGC-3' }\end{array}$ & 174 & 56,1 \\
\hline GAPDH & M17701 & $\begin{array}{l}\text { 5'-ACATCATCCCTGCATCCACT-3' } \\
\text { 5'-GGGAGTTGCTGTTGAAGTCA-3' }\end{array}$ & 258 & 55,0 \\
\hline
\end{tabular}

\# http://www.ncbi.nlm.nih.gov/entrez/query.fcgi

T.A. $=$ temperatura de anelamento 
4. RESULTADOS 


\section{Resultados}

Sensibilidade à insulina avaliada pelo teste de tolerância à insulina (ITT) em ratas durante a gestação e lactação.

O ITT foi aplicado como uma estratégia inicial para avaliar as mudanças na ação da insulina durante a gestação e a lactação. A Figura 4 mostra que, como esperado, a constante de desaparecimento de glicose está diminuída no final da gestação, indicando resistência à insulina em tecidos periféricos (músculo e tecido adiposo). A análise por ITT foi estendida por todo o período lactacional com o intuito de se caracterizar a evolução temporal da reversão da resistência à insulina que ocorre durante a lactação. A constante de desaparecimento de glicose esta aumentada no terceiro dia de lactação ( 2.4 vezes comparado ao grupo CTL; p<0.05). Quando comparada ao CTL, essa hipersensibilidade à ação da insulina permaneceu até o vigésimo primeiro dia de lactação ( 1.8 vezes em L8, 2.6 vezes L13, e 2.2 vezes em L21; p<0.05). Sete dias após o fim da lactação (PL7) a constante de desaparecimento de glicose já retoma valores semelhantes à das ratas CTL.

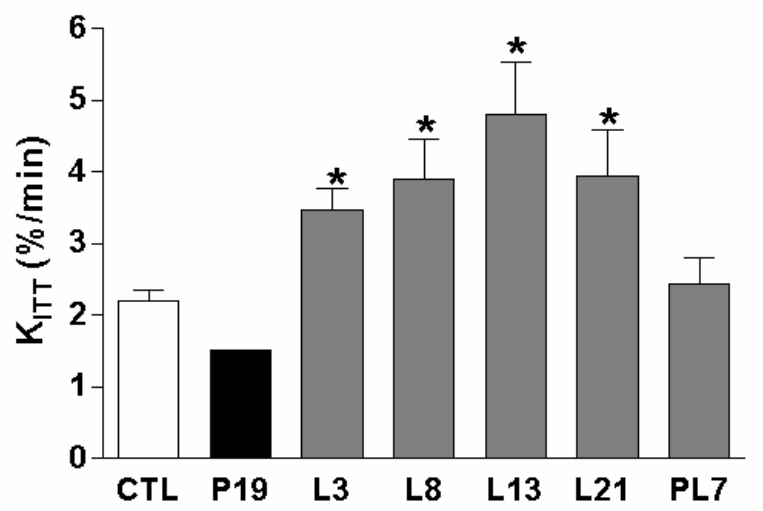

Figura 4: Sensibilidade à insulina avaliada por ITT em ratas grávidas e lactantes. Ratas CTL, P19, L3, L8, L13, L21 e PL7 receberam uma injeção intra-abdominal de insulina (2 UI/kg) em amostras de sangue forma coletadas da cauda 5, 10, 15, 20, 25 e 30 minutos após a injeção. A constante de desaparecimento de glicose $\left(K_{\text {itt }}\right)$ foi calculada usando-se a formula $0.693 / t_{1 / 2}$. As barras representam as médias \pm EPM. $* P<0,05$ vs. CTL $(\mathrm{n}=8)$ 
Dinâmica da secreção de insulina de ilhotas isoladas de ratas grávidas e lactantes

A partir do $14^{\circ}$ dia de gestação, as ratas apresentam um aumento da capacidade secretora do pâncreas endócrino. Este adaptação está presente até o final da gestação $\left(19^{\circ}\right.$ dia) e compensa a resistência à ação da insulina característica deste período. No entanto, o padrão da curva dinâmica de secreção de insulina na transição da gestação para a lactação, um período de hipersensibilidade, não está descrito. O presente resultado mostra que, em ilhotas de ratas CTL e P19, a estimulação com 16.7 mM de glicose induziu um padrão bifásico de secreção, caracterizado por um aumento de liberação de insulina proeminente e transiente (primeira fase) seguido de um segundo aumento sustentado (segunda fase) (Figura 5). Como esperado, a secreção de ilhotas de ratas P19 foi maior que a de ratas CTL. Após o parto, a secreção de insulina medida ao logo do período estimulatório (dos minutos 31 aos 50) retornou aos valores encontrados em ratas CTL. Entretanto, a primeira fase de secreção foi completamente abolida em ilhotas de ratas L3 ( $p<0.05$ comparado à CTL e à P19). Este resultado motivou os próximos experimentos que avaliaram a expressão de STAT3 e SERCA e a relação destas proteínas com este fenômeno observado no início da lactação. 


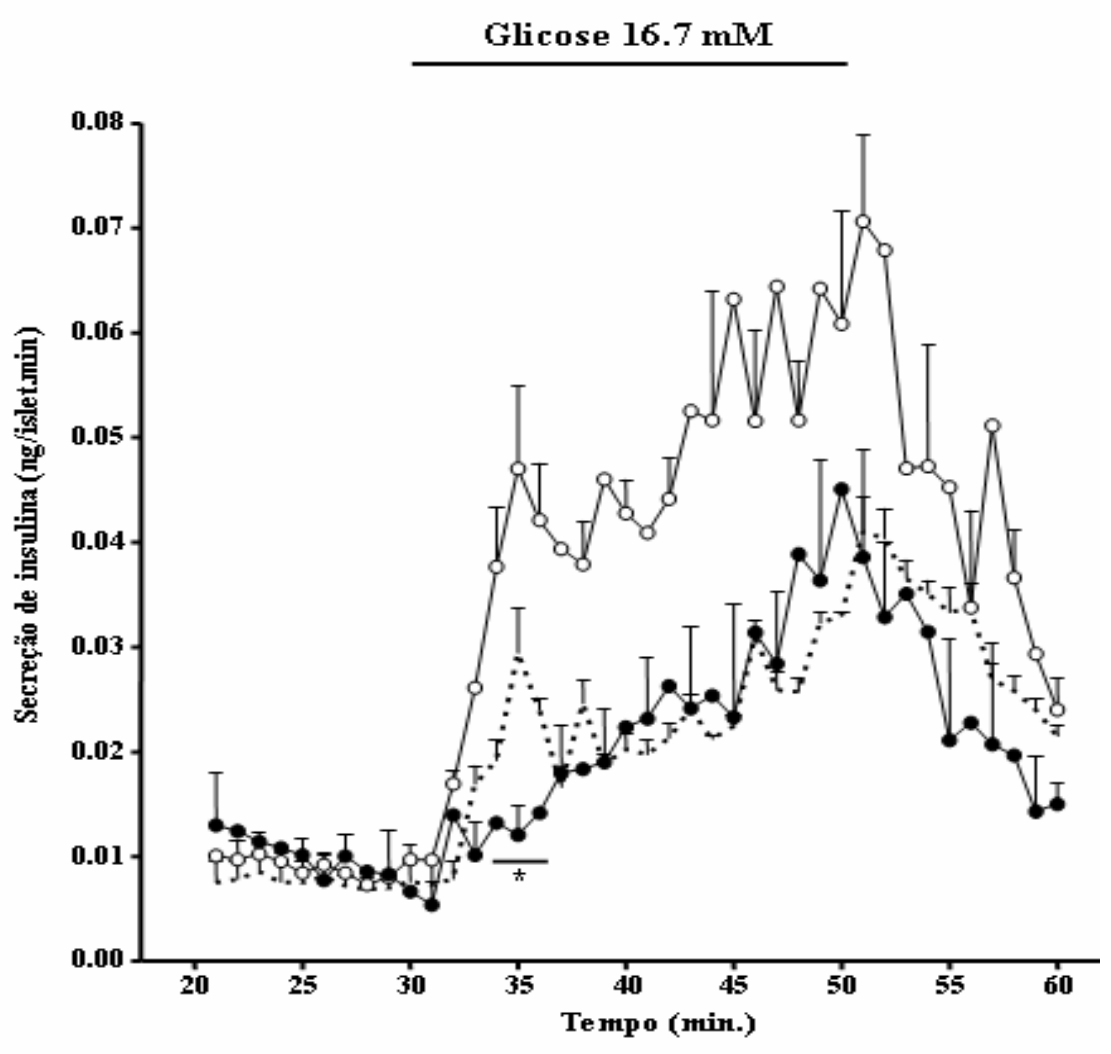

Figura 5: Dinâmica da secreção de insulina em ilhotas de ratas P19 e L3. Grupos de 20 ilhotas foram isolados de ratas CTL, P19 e L3, e perfundidas com Krebs-Hepes contendo 2,8 mM de glicose por $20 \mathrm{~min}$. A solução foi então trocada por uma contendo $16,7 \mathrm{mM}$ de glicose, e as ilhotas foram perfundidas por mais $20 \mathrm{~min}$. Após este período de estimulação, a solução foi reposta pelo tampão basal $(2,8 \mathrm{mM}$ de glicose) A linha pontilhada representa a secreção de ilhotas de ratas CTL. As linhas contínuas com círculos pretos e brancos representam ratas L3 e P19 respectivamente. Médias \pm EPM referem-se à 4 experimentos independentes. ${ }^{*} P<0.05$ vs. CTL. $(\mathrm{n}=4)$

Expressão e fosforilação do STAT3 em ilhotas pancreáticas de ratas durante a gestação e lactação.

Dentre os genes regulados positivamente em ilhotas de ratas no final da gestação, foi de especial interesse o STAT3. Contribuem para isto o fato deste gene também ser regulado positivamente em ilhotas tratadas in vitro com PRL (BORDIN et al, 2004a), um dos principais hormônios responsáveis pelas adaptações funcionais da ilhota no final da gestação, e a descrição de que ilhotas isoladas de camundongos knockout para o STAT3 apresentam uma redução significativa da primeira fase da secreção de insulina (GOROGAWA et al, 2004). Na medida em que observamos o 
bloqueio completo da primeira fase de secreção de insulina em ilhotas isoladas de ratas L3, decidimos avaliar o perfil de expressão e fosforilação desta proteína no período perinatal.

Nossos resultados mostram que o conteúdo protéico do fator de transcrição STAT3 está aumentado em ilhotas de ratas no final da gestação (P19), aumento este que persiste até o terceiro dia de lactação (L3). No oitavo dia de lactação (L8), a expressão do STAT3 já retoma valores semelhantes aos do controle (Figura 6A). A fosforilação basal em resíduos de tirosina do STAT3 não se encontra alterada no final da gestação e início da lactação (Figura 6C). Entretanto, observamos um aumento da fosforilação em resíduos de serina do STAT3 no final da gestação. Este aumento dos níveis de fosforilação em resíduos de serina do STAT3 está temporalmente limitado à gestação, pois retoma valores semelhantes aos do controle já em L3 (Figura 6B).
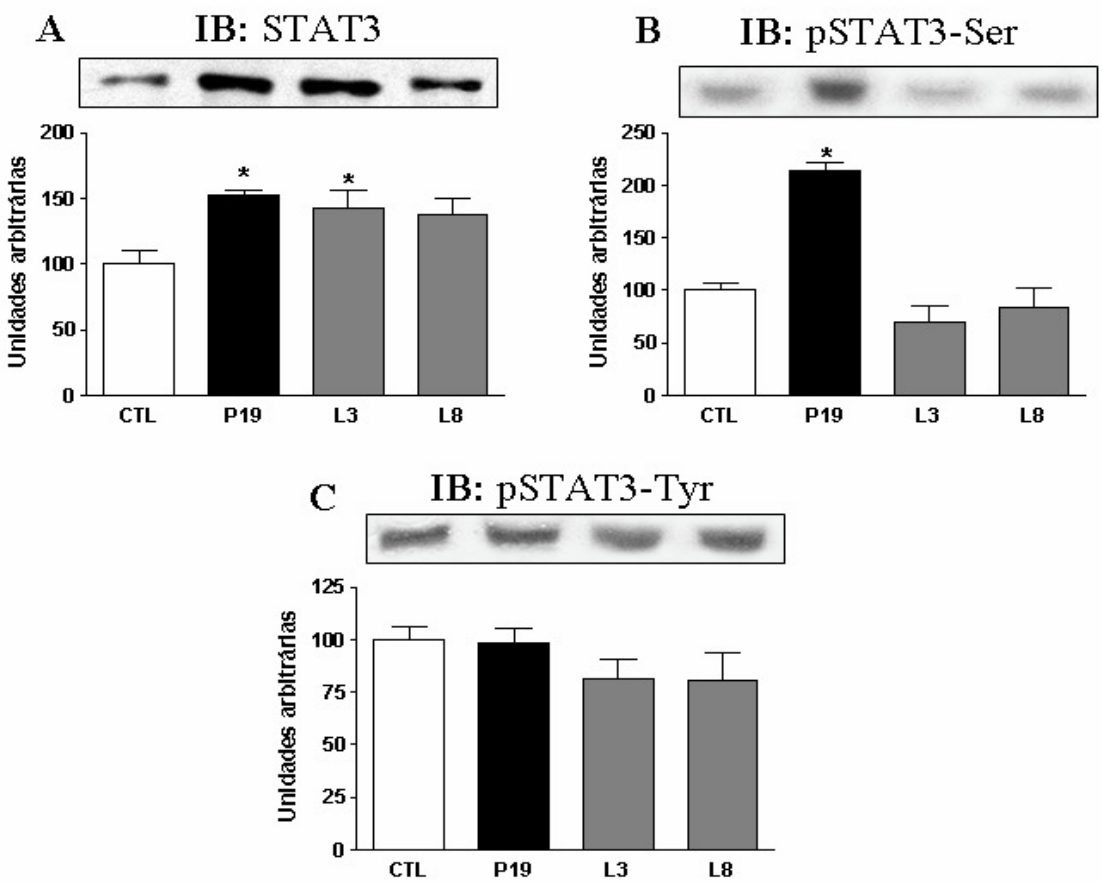

Figura 6: Expressão e fosforilação basal do STAT3 em ilhotas pancreáticas de ratas grávidas e lactantes. Ilhotas pancreáticas foram isoladas de ratas grávidas (P19) e lactantes (L3, L8). Os extratos protéicos foram processados para western blot contra STAT3 (A), pSTAT3-Ser (B) e pSTAT3-Tyr $(\mathbf{C})$. As barras representam as médias \pm EPM dos valores obtidos através de densitometria óptica. $* P<0.05$ vs. CTL. $(\mathrm{n}=5$ a 8$)$ 
Expressão de SERCA2 e SERCA3 em ilhotas pancreáticas de ratas durante a gestação e lactação e a participação da SERCA na primeira fase de secreção de insulina durante a gestação.

As proteínas SERCA (sarco/endoplasmic reticulum calcium transport ATPases) estão diretamente relacionadas ao controle do estoque intracelular de cálcio e da concentração de cálcio livre citoplasmático, e portanto potencialmente relacionadas à regulação da secreção de insulina (ARREDOUANI et al., 2002b; GILON et al., 1999). Como já descrito na introdução, os estoques intracelulares de cálcio são fundamentais para a primeira fase de secreção de insulina. Além disto, camundongos knockout para o STAT3 apresentam redução da primeira fase de secreção. Assim, a análise da expressão das isoformas de SERCA foi realizada com o intuito de se investigar um provável mecanismo pelo qual o STAT3 poderia regular a diminuição da primeira fase de secreção de insulina em ilhotas de ratas L3.

A análise da expressão protéica das principais isoformas desta proteína mostrou que o conteúdo protéico de SERCA3 não está alterado em ilhotas de ratas em P19 e L3. Já o conteúdo protéico de SERCA2 encontra-se aumentado em P19 e retoma valores semelhantes aos do controle em L3 e L8 (Respectivamente, Figuras 7A e 7B). A Figura 7C mostra que o bloqueio farmacológico da SERCA em ilhotas de ratas P19 resulta na supressão da primeira fase de secreção de insulina ( $P<0.05$ vs. CTL). Em contraste, observa-se uma tendência de aumento na segunda fase de secreção de insulina de ilhotas de ratas P19 tratadas com thapsigargin. 
A
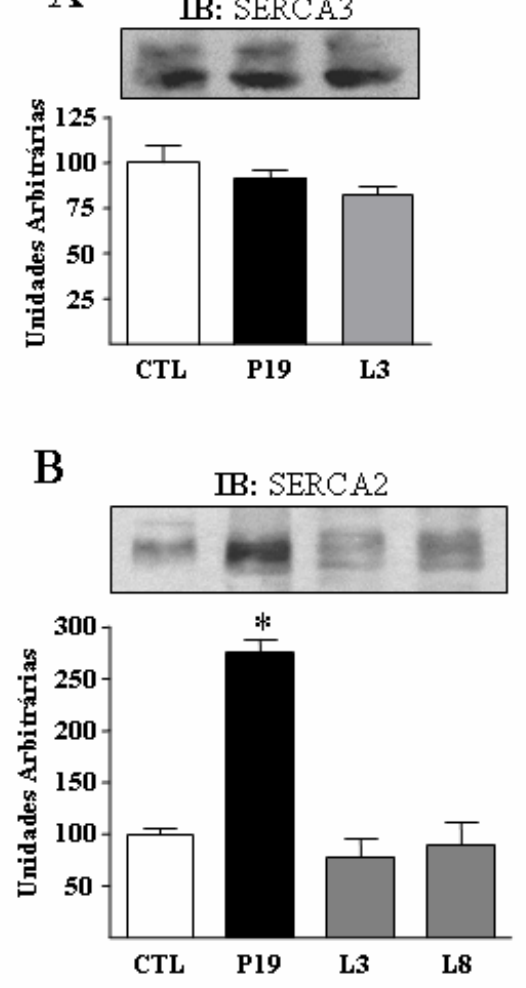

$\mathrm{C}$

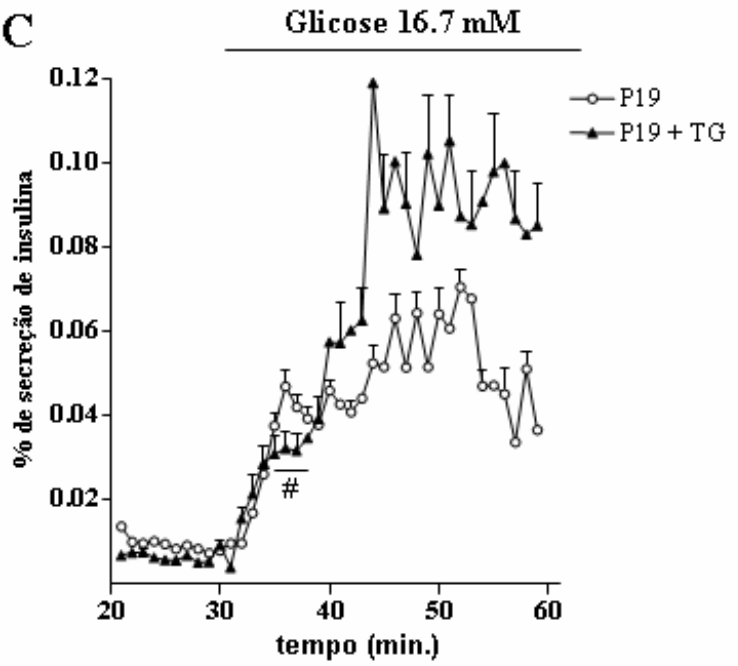

Figura 7: Expressão de SERCA3 e SERCA2 em ilhotas pancreáticas de ratas grávidas e lactantes e sua participação na dinâmica de secreção de insulina de ratas no final da gestação. Ilhotas pancreáticas foram isoladas de ratas grávidas (P19) e lactantes (L3, L8). Os extratos protéicos foram processados para western blot contra SERCA3 (A) e SERCA2 (B). Em paralelo, ilhotas de ratas P19 foram pré-incubadas na presença ou na ausência de thapsigargin e em seguida utilizadas para ensaio de secreção dinâmica de insulina (C). As barras representam as médias \pm EPM dos valores obtidos através de densitometria óptica. ${ }^{*} P<0.05$ vs. CTL. $(\mathrm{n}=3$ a 4$)$

Especificidade e eficiência do oligonucleotídeo fosfotioado antisense para o STAT3.

A análise por Western blot em células RINm5F transfectadas com o oligonucleotídeo antisense para o STAT3 (ASO) revelaram que o oligonucleotídeo utilizado reduziu eficientemente o conteúdo protéico do STAT3 de maneira específica, uma vez que não alterou o conteúdo protéico do STAT5 e da $\alpha$-tubulina. Além disso, este efeito não decorre de uma ação não específica do oligonucleotídeo antisense, uma vez que o oligonucleotídeo controle (S) não alterou o conteúdo protéico do STAT3 (Figura 8A). 
A exemplo do observado em ilhotas pancreáticas de camundongos knockout para o STAT3 (GOROGAWA et al. 2004), o conteúdo do mRNA do GLUT2 e do SUR1 estão diminuídos em células RINm5F transfectadas com o oligonucleotídeo antisense para o STAT3 (ASO) (Figuras 8B e 8C, respectivamente).

O tratamento de células RINm5F com PRL por 24 horas aumentou o conteúdo protéico do STAT3. A presença do oligonucleotídeo antisense para o STAT3 impediu o efeito positivo da PRL sobre sua expressão. (Figura 8D).
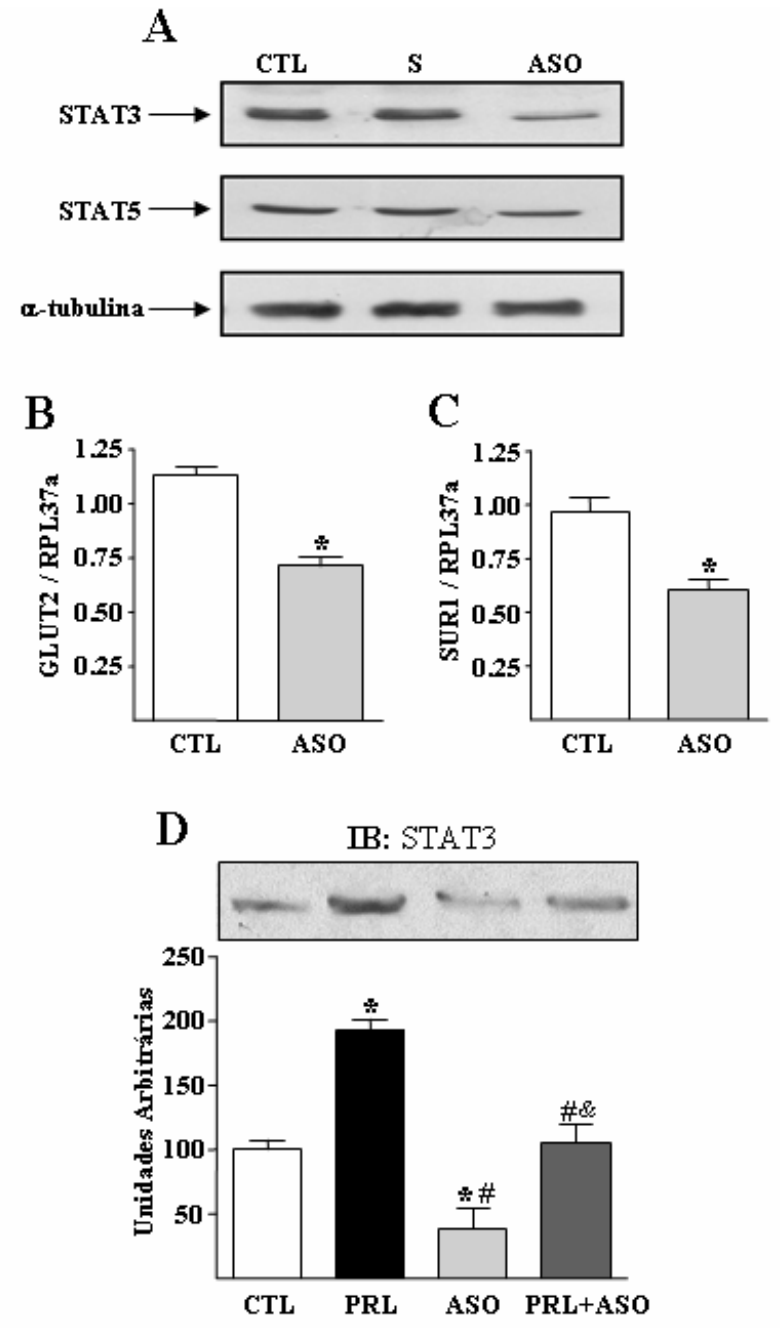

Figura 8: Bloqueio do STAT3 em células RINm5F e modulação do mRNA do SUR1 e do GLUT2. Células RINm5F foram transfectadas com oligonucleotídeo antisense para o STAT3 (ASO) e com um oligonucleotídeo controle (S). As células controle (CTL) foram tratadas somente com lipofectamina. 24 horas depois da transfecção as células foram processadas para western blot contra STAT3, STAT5 e $\alpha-$ Tubulin (A) e para RT-PCR do mRNA do GLUT2 (B) e do SUR1 (C). Depois da transfecção, um grupo separado de células foi tratado com PRL por 24 horas em um meio sem soro com 1\% de BSA. Após o tratamento, as células foram processadas para western blot contra STAT3 (D). As barras representam as médias \pm EPM dos valores obtidos através de densitometria óptica. ${ }^{*} P<0.05$ vs. CTL; \# $P<0.05$ vs. PRL e $\& P<0.05$ vs. ASO. $(\mathrm{n}=5$ a 7$)$ 
Efeito da PRL sobre a fosforilação em resíduos de serina do STAT3 e a expressão das SERCAs e sua correlação com a secreção de insulina.

A PRL aumentou a fosforilação em resíduos de serina do STAT3 em células RINm5F. Este efeito foi bloqueado pela presença do oligonucleotídeo antisense para o STAT3 (Figura 9A).

A PRL aumenta o conteúdo protéico de SERCA2 em células RINm5F. Este efeito é dependente do aumento da expressão do STAT3, uma vez a PRL não exerce efeitos sobre a expressão de SERCA2 na presença do oligonucleotídeo antisense para o STAT3 (Figura 9B). O efeito da PRL é específico para a SERCA2, na medida em que não se observou alteração no conteúdo protéico da SERCA3 (Figura 9C). De maneira aparentemente contraditória, a Figura 9D mostra que o bloqueio da expressão de STAT3 causa um aumento da secreção cumulativa de insulina após 1 hora de estimulação com glicose $16.7 \mathrm{mM}$, sem alterar a secreção basal de insulina $(P<0.05$ vs. CTL com $16.7 \mathrm{mM}$ de glicose). 

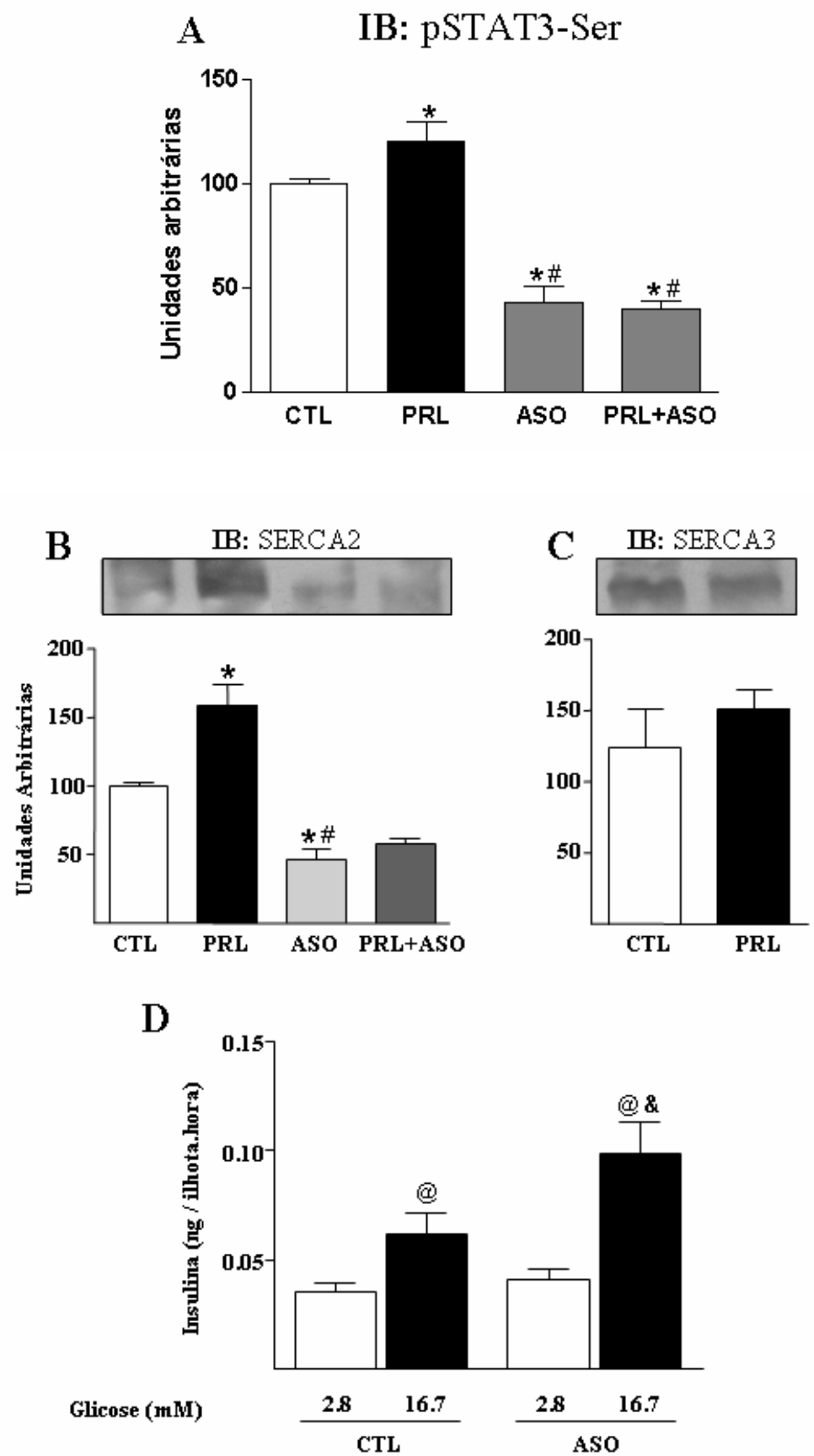

Figura 9: Efeito da PRL e do bloqueio do STAT3 na fosforilação em serina do STAT3 e na expressão de SERCA2 em células RINm5F e efeito do bloqueio do STAT3 sobre a secreção de insulina de ilhotas pancreáticas. Células RINm5F CTL e transfectadas com ASO foram tratadas com PRL por 24 horas em um meio sem soro com 1\% de BSA. Após o tratamento, as células foram processadas para western blot contra pSTAT3-Ser (A), SERCA2 (B) e SERCA3 (C). Ilhotas transfectadas com oligonucleotídeo antisense para o STAT3 (ASO) e não transfectadas (CTL) foram incubadas na presença de 2.8 e $16.7 \mathrm{mM}$ de glicose e usadas para ensaio cumulativo de secreção de insulina (D). As barras representam as médias \pm EPM dos valores obtidos através de densitometria óptica e de RIA. $* P<0.05$ vs. CTL; \# $P<0.05$ vs. PRL; $@ P<0.05$ vs. $2.8 \mathrm{mM}$ de glicose; $\& P<0.05$ vs. CTL com $16.7 \mathrm{mM}$ de glicose. ( $\mathrm{n}=3$ a 12$)$ 
Expressão das enzimas $11 \beta$-HSD1 e $11 \beta$-HSD2 em ilhotas de ratas grávidas e lactantes.

Até o momento se aceita que a reversão fisiológica dos efeitos da PRL sobre a célula $\beta$ seja mediada pelos altos níveis de GCs circulantes característicos do final da

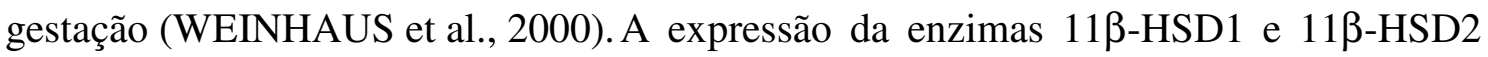
que geram, respectivamente, as formas ativas e inativas de glicocorticóides (representados em ratos pela corticosterona e pela cortisona, respectivamente) deve participar do equilíbrio intracelular destes hormônios, modulando assim suas ações nas ilhotas pancreáticas. Nossos resultados mostram uma diminuição da expressão de $11 \beta$ HSD1 em ilhotas de ratas grávidas. Esta diminuição sofre reversão parcial no início da lactação (Figura 10A). A enzima 11ß-HSD2 não está alterada em ilhotas de ratas P19, mas está reduzida em ilhotas de ratas L3 (Figura 10B).

A

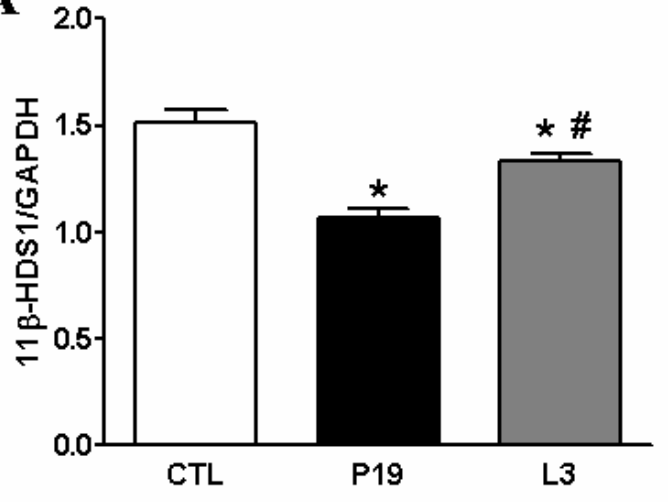

B

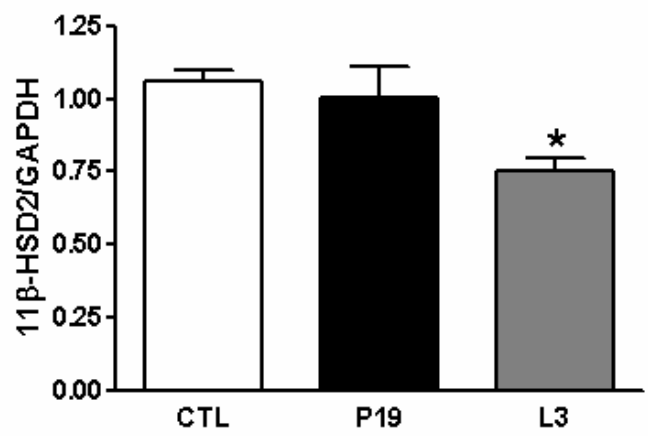

Figura 10: Expressão das enzimas 11 $\beta$-HSD1 e 11 $\beta$-HSD2 em ilhotas de ratas grávidas e lactantes. Ilhotas isoladas a partir de ratas CTL, P19 e L3 foram processadas para análise da

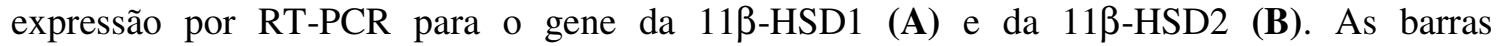
representam as médias \pm EPM dos valores obtidos por densitometria óptica e normalizados pelo valor obtido da amplificação do gene constitutivo GAPDH. *P $<0.05$ vs. CTL; \# P<0.05 vs. L3. $(n=3)$ 
Efeito da DEX e da PRL sobre a expressão e fosforilação do STAT3 em células

RINm5F.

Escolhemos com estratégia experimental o tratamento isolado e combinado de células RINm5F com PRL e DEX, a fim de se reproduzir in vitro algumas das alterações hormonais características do início da lactação. A Figura 11A mostra que o aumento do conteúdo protéico do STAT3 induzido pela PRL não é modulado pela presença de DEX. DEX isoladamente também não altera o conteúdo do STAT3 (Figura 11A). A fosforilação em resíduos de tirosina do STAT3 não é modulada pela PRL, pela DEX e pela combinação de ambos (Figura 11B).

O estímulo da fosforilação em resíduo de serina do STAT3 pela PRL foi bloqueado pela adição de DEX ao meio de cultura. DEX isoladamente também reduziu a fosforilação em resíduo de serina do STAT3 (Figura 11C). 


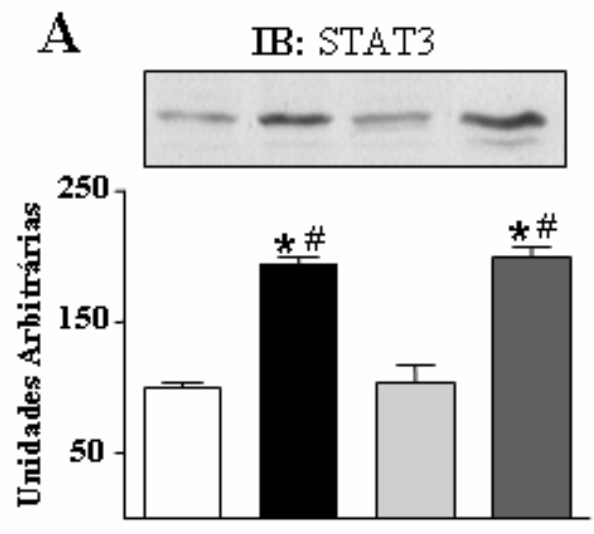

B IB: pSTAT3-(Tyr)

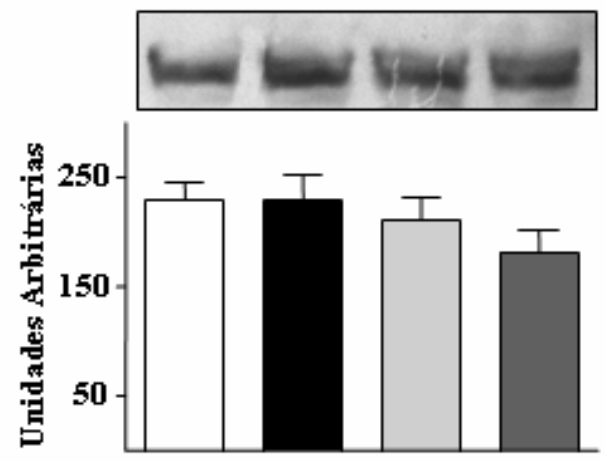

C IB: pSTAT3-(Ser)

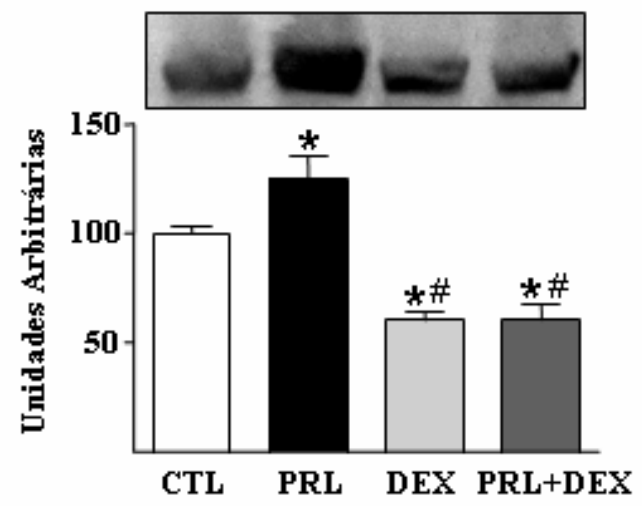

Figura 11: Efeito da DEX e da PRL sobre a expressão e fosforilação do STAT3 em células RINm5F. Células RINm5F foram tratadas com PRL e DEX isoladamente ou a combinação de ambos (PRL+DEX) por 24 horas. Após o tratamento, as células foram processadas para western blot contra STAT3 (A), pSTAT3-Tyr (B) e pSTAT3-Ser (C). As barras representam as médias \pm EPM dos valores obtidos através de densitometria óptica. ${ }^{*} P<0.05$ vs. CTL; \# $P<0.05$ vs. PRL. (n=7) 
Efeito da DEX e da PRL sobre a expressão SERCA2 em células RINm5F e ilhotas pancreáticas de ratas.

O aumento da expressão de SERCA2 na célula RINm5F induzido pela PRL foi bloqueado pela adição de DEX ao meio de cultura. É importante notar que, a exemplo da fosforilação em serina do STAT3, a DEX isoladamente diminui a expressão de SERCA2 para valores inferiores ao das células CTL (Figura 12A). PRL também induz o aumento do mRNA da SERCA2 no cultivo primário de ilhotas pancreáticas de ratas adultas. Este efeito da PRL também é contra-regulado pela adição de DEX ao meio de cultivo. Neste caso, a DEX isoladamente não alterou a expressão de SERCA2 (Figura 12B).
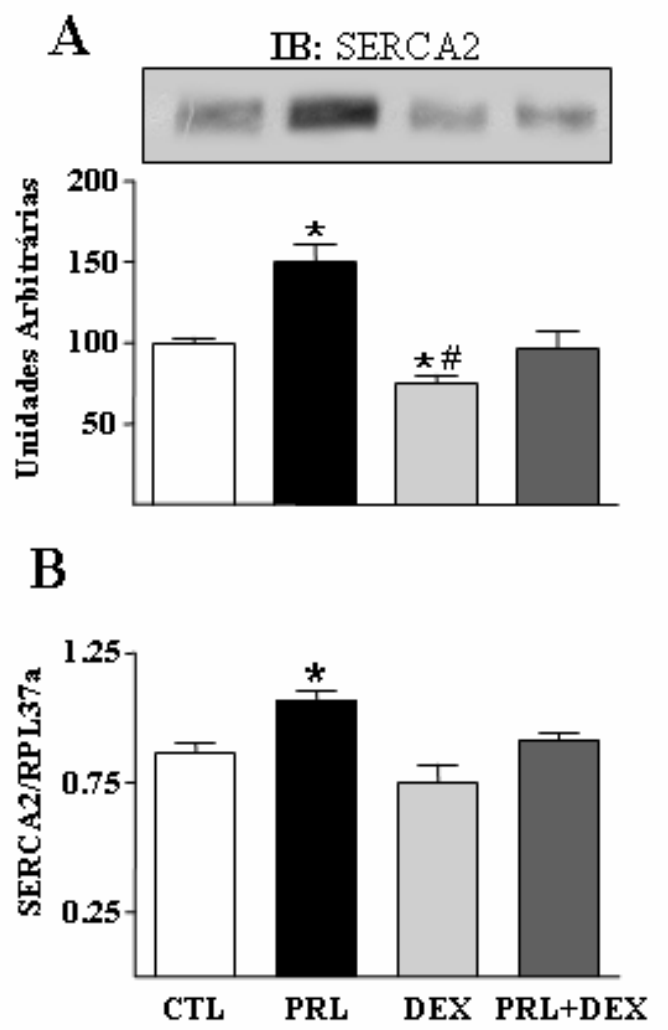

Figura 12: Efeito da DEX e da PRL sobre a expressão de SERCA2 em células RINm5F e ilhotas pancreáticas de ratas. Células RINm5F e ilhotas isoladas de ratas foram tratadas com PRL e DEX isoladamente ou a combinação de ambos (PRL+DEX) por 24 horas. Após o tratamento, as células foram processadas para western blot contra SERCA2 (A) e as ilhotas processadas para RT-PCR para o gene da SERCA2 (B). As barras representam as médias \pm EPM dos valores obtidos através de densitometria óptica. No caso do RT-PCR, os valores foram normalizados pela densitometria do gene constitutivo RPL37a* $P<0.05$ vs. CTL; $\# P<0.05$ vs. PRL. (n=4) 
Fosforilação e expressão das proteínas das vias da AKT e ERK1/2 em ilhotas

pancreáticas de ratas grávidas e lactantes.

Foi demonstrado que as vias da AKT/p70S6K e da ERK1/2 estão envolvidas na adaptação funcional promovida pela PRL em ilhotas pancreáticas de ratas no final da gestação (AMARAL et al. 2004). Nossos resultados de expressão gênica por macroarray mostram que a expressão de AKT1 está aumentada neste período, concomitante com um aumento do $c$-fos e do $c$-jun, dois genes alvos das ERK 1/2 (SNG, TANIURA \& YONEDA, 2004). Além disto, se aceita que tanto as ERK1/2 quanto a AKT podem modular diretamente a fosforilação do STAT3 em resíduos de serina (CERESA, HORVATH \& PESSIN, 1997; FUNG, ROHWER \& MCGUIRE, 2003). A avaliação da expressão e fosforilação das proteínas relacionadas a estas vias foi empregada com o intuito de se de investigar, de maneira mais ampla, a participação dos GCs na regressão do pâncreas endócrino no começo da lactação. A Figura 13A mostra que a fosforilação em resíduos de serina da AKT1 está aumentada em ilhotas de ratas P19 (P < 0,05 vs. CTL) e retorna aos valores semelhantes aos do CTL em L3. Já a expressão de AKT1 aumentou em ilhotas de ratas P19 e este aumento permaneceu até L3 (P < 0,05 vs. CTL) (Figura 13B). O mesmo padrão de fosforilação e expressão foi encontrado para sua proteína-alvo p70S6K, respectivamente Figuras 13C e 13D. 

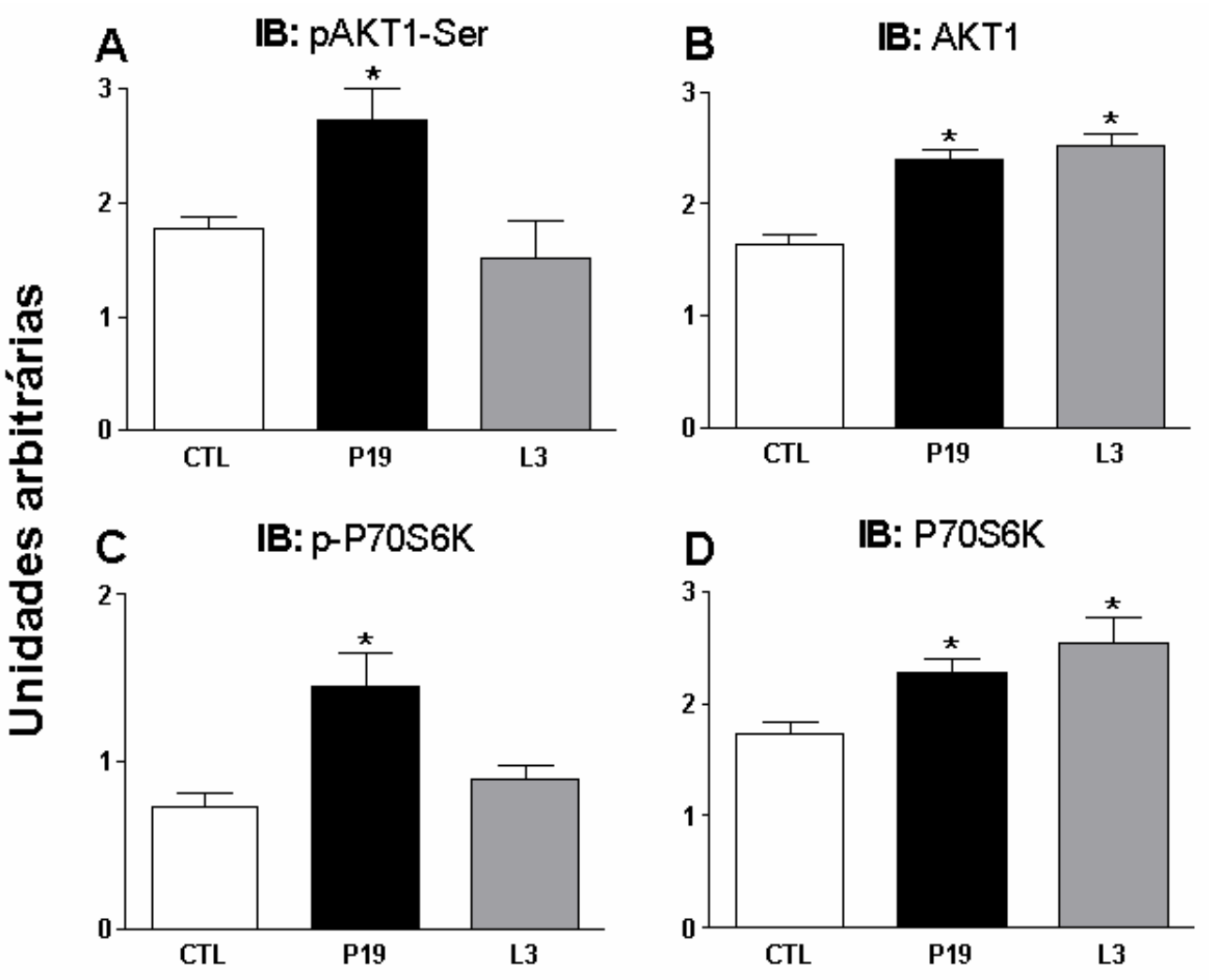

Figura 13: Expressão e fosforilação da AKT1 e da P70S6K em ilhotas pancreáticas de ratas grávidas e lactantes. Ilhotas pancreáticas foram isoladas de ratas CTL, P19 e L3. Os extratos protéicos foram processados para western blot contra pAKT1-Ser (A), AKT1 (B), p-P70S6K (C) e P70S6K (D). As barras representam as médias \pm EPM dos valores obtidos através de densitometria óptica. ${ }^{*} P<0.05$ vs. CTL. (n=3 a 7 )

A Figura 14B mostra que a fosforilação das ERK1/2 em resíduos de tirosina e treonina está aumentada em ilhotas de ratas P19, quando comparadas a ilhotas de ratas CTL (P < 0,05). Já em ilhotas isoladas de ratas L3, a fosforilação das ERK1/2 está reduzida a valores menores que os observados em ratas CTL $(\mathrm{P}<0,05)$. A Figura 14A mostra que o conteúdo protéico das ERK1/2 não está alterado neste período. 
A

IB: ERK $1 / 2$

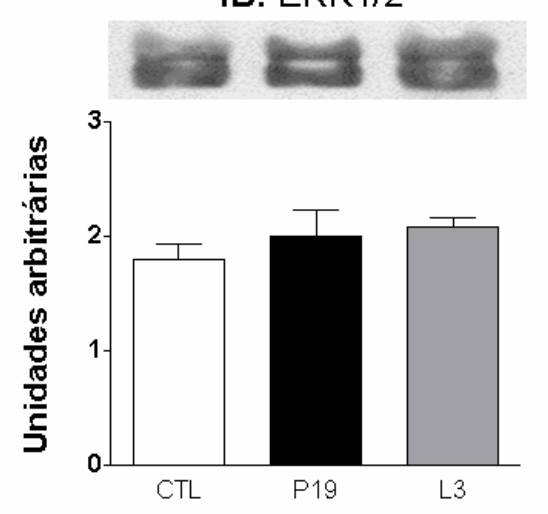

B IB: p-ERK $1 / 2 \mathrm{Thr} / \mathrm{Tyr}$

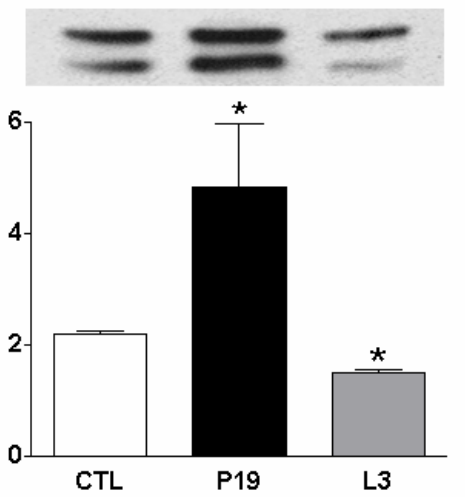

Figura 14: Expressão e fosforilação das ERK 1/2 em ilhotas pancreáticas de ratas grávidas e lactantes. Ilhotas pancreáticas foram isoladas de ratas CTL, P19 e L3. Os extratos protéicos foram processados para western blot contra ERK 1/2 (A) e p-ERK 1/2 Thr/tyr (B). As barras representam as médias $\pm \mathrm{EPM}$ dos valores obtidos através de densitometria óptica. $* P<0.05$ vs. CTL. $(\mathrm{n}=4)$

Efeito da PRL e da DEX na expressão e fosforilação da AKT1 e das ERK 1/2 em células RINm5F.

A Figura 15A e 15B mostram, respectivamente, que PRL e DEX aumentam a expressão e a fosforilação em serina da AKT1 em células RINm5F. Tal aumento ocorre em igual magnitude quando os dois agentes combinados são acrescentados ao meio de cultura ( $\mathrm{P}<0,05$ vs. CTL). Já as ERK1/2 são moduladas de maneira distinta. PRL e DEX isoladas ou combinadas não afetam a expressão das ERK 1/2 em células RINm5F (Figura 15C). A fosforilação das ERK1/2 não é modulada pela PRL, mas está diminuída em células RINm5F tratadas com DEX, isoladamente e em combinação com PRL (P < 0,05 vs. CTL) (Figura 15D). 

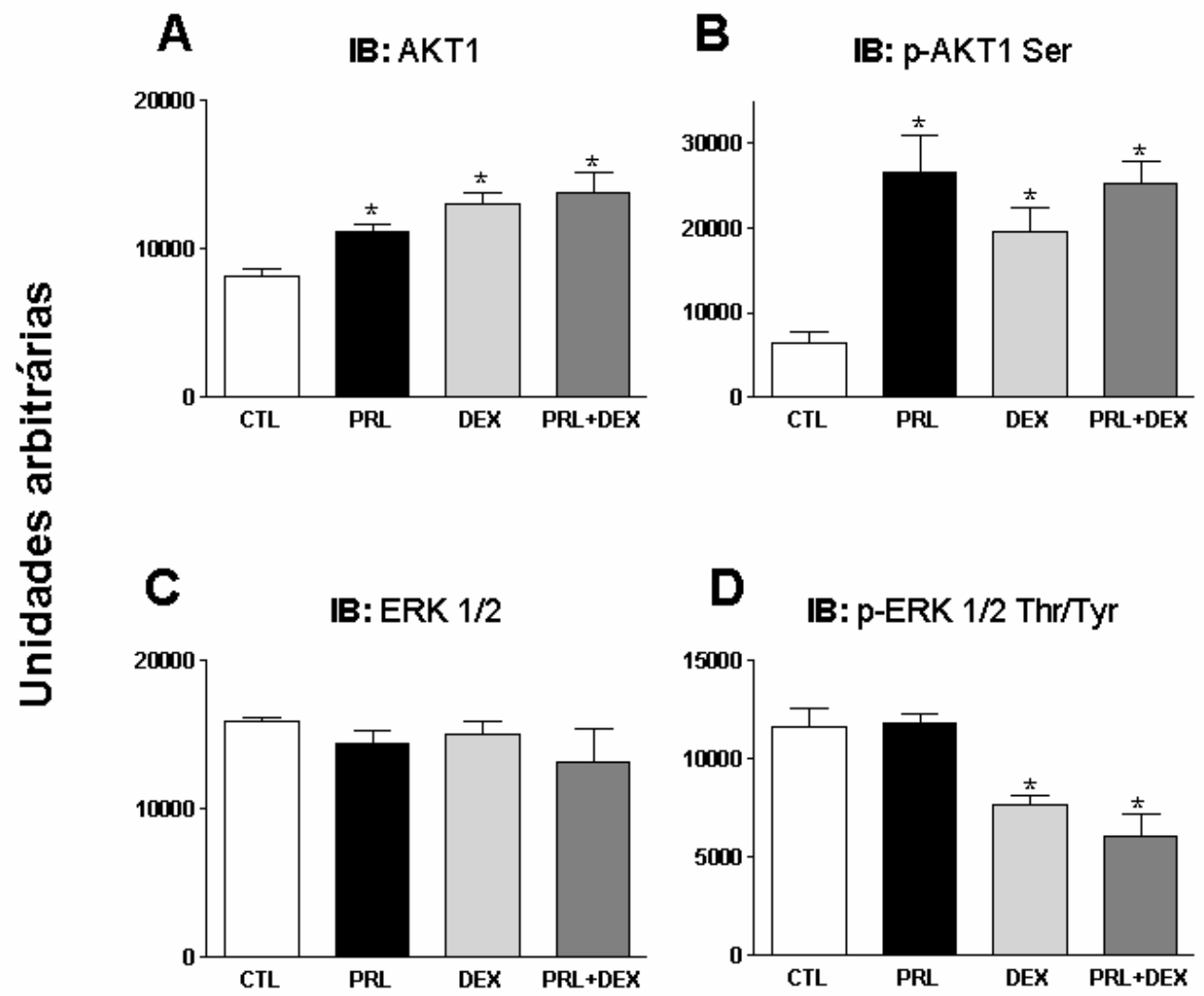

Figura 15: Efeito da DEX e da PRL sobre a expressão e fosforilação da AKT1 e das ERK 1/2 em células RINm5F. Células RINm5F foram tratadas com PRL e DEX isoladamente ou com a combinação de ambos (PRL+DEX) por 24 horas. Após o tratamento, as células foram processadas para western blot contra AKT1 (A), pAKT1-Ser (B), ERK 1/2 (C) e p-ERK 1/2 Thr/Tyr (D). As barras representam as médias \pm EPM dos valores obtidos através de densitometria óptica. ${ }^{*} P<0.05$ vs. CTL; \# $P<0.05$ vs. PRL. $(n=6)$

Expressão do mRNA de fosfatases relacionadas à via da ERK 1/2 em ilhotas pancreáticas de ratas $L 3$.

As ERK 1/2 são ativadas por fosforilação em resíduos de treonina e tirosina por proteínas quinases denominadas MAPKK (Mitogen Activated Protein Kinase Kinase) e desativadas por desfosforilação nos resíduos de treonina ou em ambos os resíduos (KONDOH \& NISHIDA, 2006). Dentre as fosfatases de especificidade dupla (tirosina/treonina) encontram-se as MKPs (Mitogen Activated Protein Kinase Phosphatases) (KONDOH \& NISHIDA, 2006). Neste sentido, avaliamos a expressão das principais MKPs em ilhotas de ratas CTL e L3, e em células RINm5F CTL e tratadas com DEX. O gene que codifica a proteína SGK (Serum- and Glucocoticoid- 
induced kinase) foi escolhido como controle do tratamento, na medida em que é descrito como gene regulado por glicocorticóides em diversos tecidos de roedores (WEBSTER et al., 1993).

A expressão dos genes da MKP1 e da SGK aumentou em ilhotas de ratas L3 (respectivamente Figuras 16A e 16B, P < 0.05 vs. CTL), e a expressão de MKP2 diminuiu nesta última condição (Figura 16C; P $<0.05$ vs. CTL). Não foi observada modulação na expressão dos genes da MKP3 em ilhotas de ratas L3 (Figura 16D).
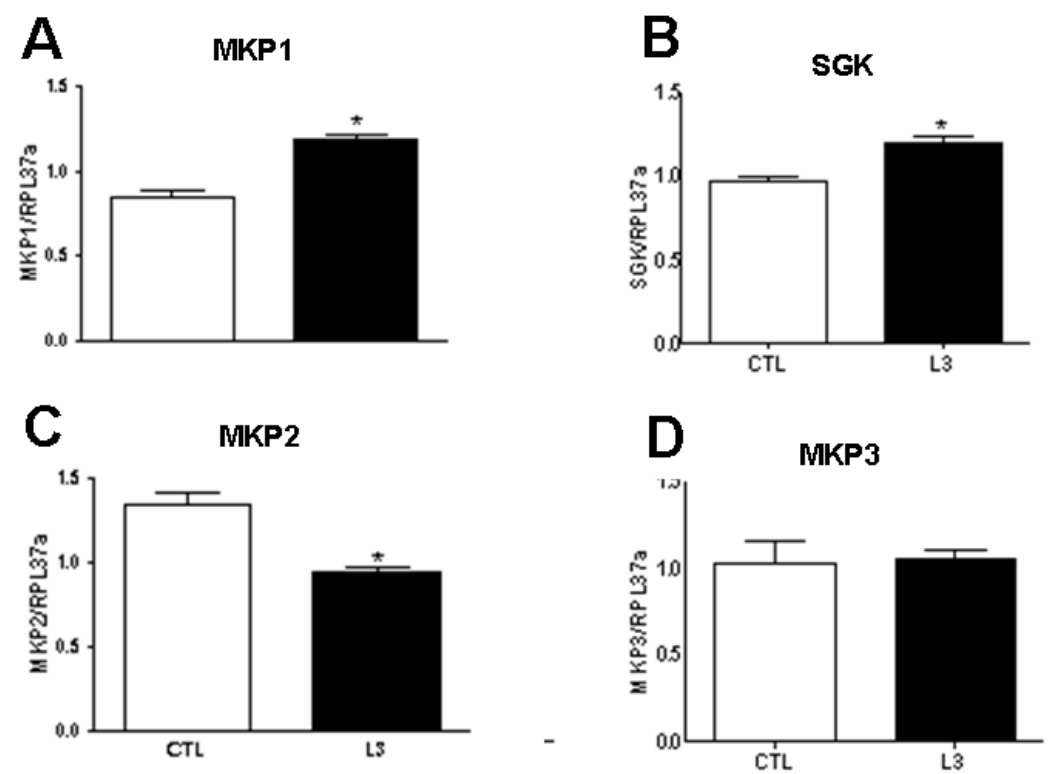

Figura 16: Expressão do mRNA de fosfatases relacionadas à via da ERK 1/2 em ilhotas pancreáticas de ratas L3. Ilhotas pancreáticas foram isoladas de ratas CTL e L3. O RNA total foi extraído e as amostras foram submetidas a RT-PCR para MKP1 (A), SGK (B), MKP2 (C) e MKP3 (D). As barras representam as médias \pm EPM dos valores obtidos através de densitometria óptica. $* P<0.05$ vs. CTL. $(\mathrm{n}=3)$ 
Expressão do mRNA de fosfatases relacionadas à via da ERK 1/2 em células RINm5F tratadas com DEX.

O padrão de expressão das fosfatases MKP em células de insulinoma tratadas com o GC sintético é idêntico ao observado em ilhotas de ratas L3. A expressão dos genes da SGK e da MKP1 aumentou em células RINm5F tratadas com DEX (respectivamente Figuras 17A e 17B, $\mathrm{P}<0.05$ vs. CTL). A Figura $17 \mathrm{C}$ mostra que células RINm5F tratadas com DEX apresentam uma menor expressão de MKP2 $(\mathrm{P}<$ 0.05 vs. CTL). Não foi observda modulação na expressão do gene da MKP3 em células RINm5F tratadas com DEX (Figura 17D).
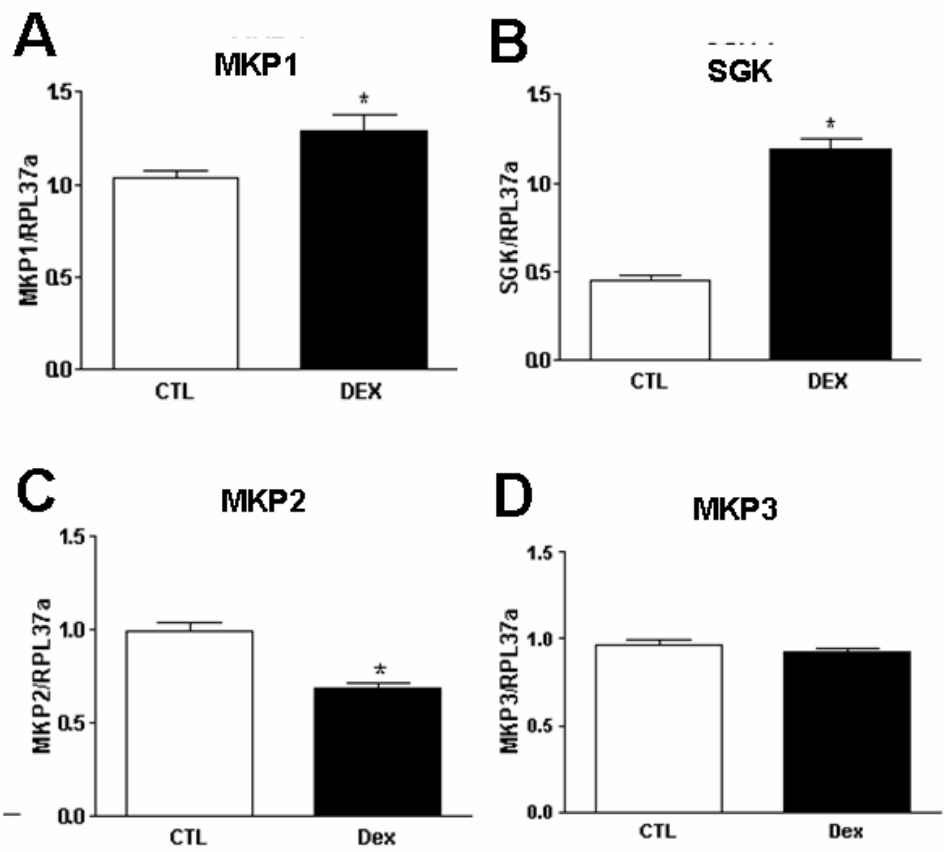

Figura 17: Expressão do mRNA de fosfatases relacionadas à via da ERK 1/2 em células RINm5F tratadas com DEX. Células RINm5F forma tratadas com DEX $100 \mathrm{nM}$ por 24 horas (DEX). O RNA total das células tratadas e das células CTL foi extraído e as amostras foram submetidas a RT-PCR para MKP1 (A), SGK (B), MKP2 (C) e MKP3 (D). As barras representam as médias \pm EPM dos valores obtidos através de densitometria óptica. $* P<0.05$ vs. CTL. $(n=3)$ 
Captação de glicose, síntese de glicogênio e produção de $\mathrm{CO}_{2}$ no músculo solear de ratas lactantes.

Os resultados aqui apresentados demonstraram que, no início da lactação, a homeostasia glicêmica é alcançada simultaneamente com um quadro de hipersensibilidade à ação da insulina (Figura 4). Este fenômeno aparece de maneira concomitante com uma redução da capacidade secretora do pâncreas endócrino (Figura 5). Desta maneira, a melhora da ação da insulina em tecidos responsivos foi investigada para a melhor compreensão desta adaptação metabólica do periparto. O músculo solear foi escolhido como um músculo representativo do comportamento das fibras oxidativas ( $87 \%$ de fibras oxidativas), e o plantares como representativo das fibras glicolíticas ( 91\% de fibras glicolíticas) (ARMSTRONG \& PHELPS, 1984).

A captação de glicose no músculo solear, basal e estimulada por insulina na concentração de $0.1 \mathrm{mU} / \mathrm{mL}$, atingiu valores semelhantes aos do CTL em L3, L8 e L13. Entretanto, a captação máxima do músculo solear estimulada pela presença de insulina na concentração de $10 \mathrm{mU} / \mathrm{mL}$ foi maior em ratas L3 de que em ratas CTL, e similar entre as ratas CTL, L8 e L13 (Figura 18A). O destino da glicose captada pelo músculo de ratas lactantes foi avaliado pela medida da síntese de glicogênio e da produção de $\mathrm{CO}_{2}$. A síntese de glicogênio basal e estimulada pela insulina alcançou valores similares em músculo solear de ratas CTL, L3, L8 e L13 (Figura 18B). A produção de $\mathrm{CO}_{2}$ induzida por doses máximas de insulina no músculo solear isolados de ratas L3 foi maior que aquela observada em músculos de ratas CTL $(\sim 1.44$ vezes; $\mathrm{p}<0.05)$. Já a produção de $\mathrm{CO}_{2}$ basal e induzida por doses intermediárias de insulina foi semelhante para os músculos isolados de ratas CTL, L3, L8 e L13 (Figura 18C). 

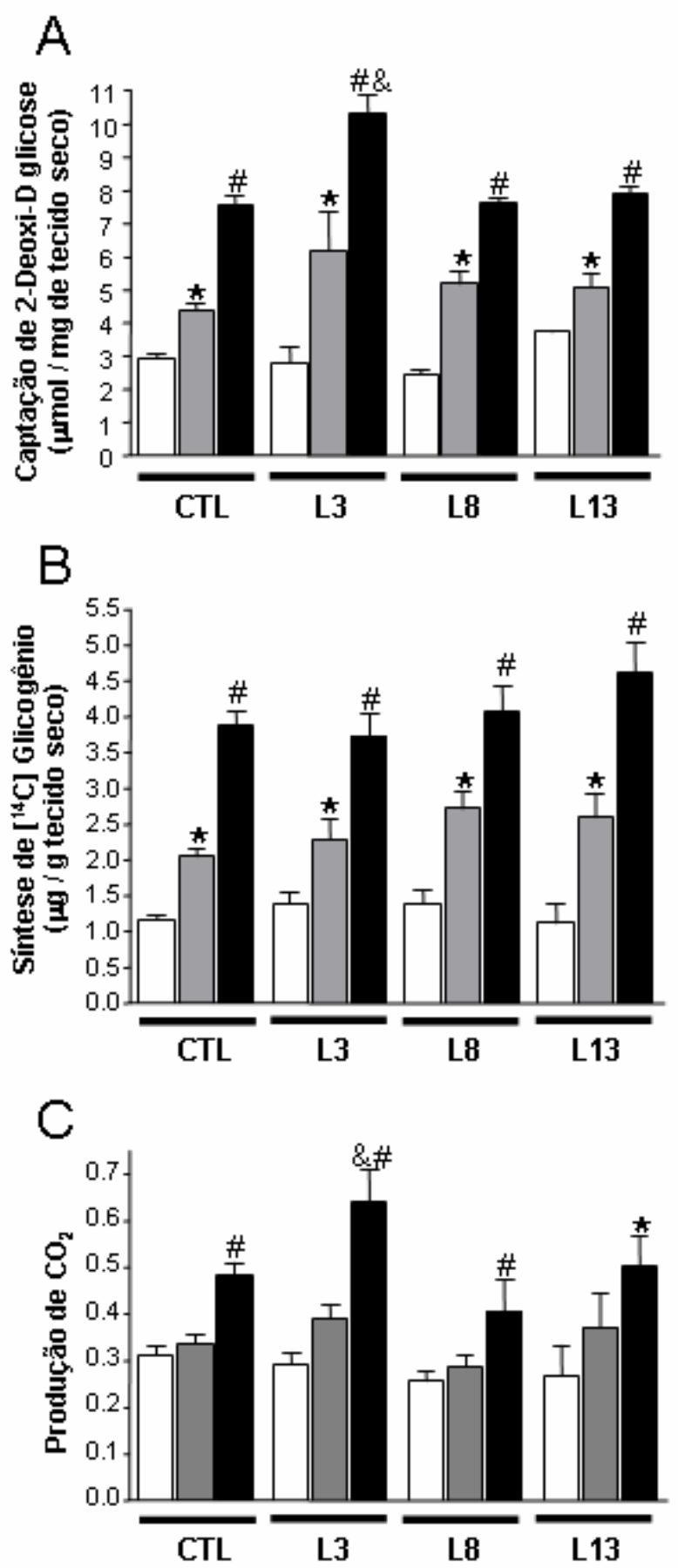

Figura 18: Captação de glicose, síntese de glicogênio e produção de $\mathrm{CO}_{2}$ no músculo solear isolados de ratas CTL e lactantes. Ratas CTL, L3, L8 e L13 foram sacrificadas e o músculo solear foi rapidamente isolado e processado para os ensaios de captação de 2-deoxi-D-[2,6- $\left.{ }^{3} \mathrm{H}\right]-$ glicose (A), síntese de $\left[{ }^{14} \mathrm{C}\right]$-Glicogênios $(\mathbf{B})$ e produção de ${ }^{14} \mathrm{CO}_{2}(\mathbf{C})$. As barras representam as médias \pm EPM obtidas de três experimentos independentes. A barras brancas correspondem à ausência de insulina, as barras cinzas correspondem à presença de insulina na concentração de 0.1 $\mathrm{mU} / \mathrm{mL}$ e as barras pretas correspondem a presença de insulina na concentração de $10 \mathrm{mU} / \mathrm{mL}$.* $\mathrm{p}<0,05$ vs. basal dentro do mesmo grupo; \# p $<0,05$ vs. insulina $0.1 \mathrm{mU} / \mathrm{mL}$ dentro do mesmo grupo; \& $P<0,05$ vs. CTL incubado com insulina na concentração de $10 \mathrm{mU} / \mathrm{mL}$. (n=3 a 6) 
Expressão de GLUT4 no músculo solear e plantares isolados de ratas lactantes

A expressão de GLUT4 foi abordada com o intuito de investigar o mecanismo envolvido no aumento da captação de glicose observado no músculo solear de ratas no início da lactação. A quantidade relativa do mRNA do GLUT4 está aumentada em músculo solear de ratas L3 quando comparadas às ratas CTL $(\sim 1.23$ vezes; p<0.05). Este aumento já não é observado em L8 e L13 (Figura 19A). O conteúdo protéico de GLUT4 no músculo solear também foi avaliado e revelou um aumento em ratas L3 em relação a ratas CTL ( 1.85 vezes; p<0.05) (Figura 19B). Já no músculo plantares foi observada uma diminuição do conteúdo protéico de GLUT4 de ratas L3, quando comparadas com ratas CTL ( 0.40 vezes; $\mathrm{p}<0.05)$ (Figure 19C).
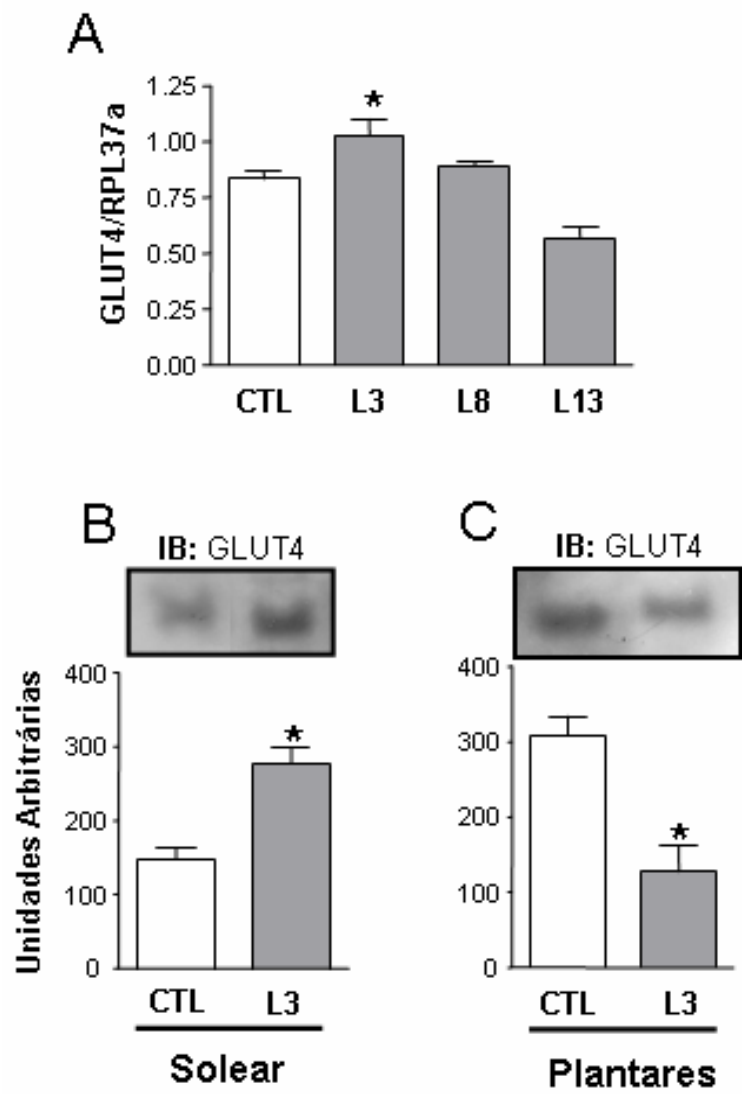

Figura 19: Expressão de GLUT4 em solear e plantares de ratas CTL e lactantes. Ratas CTL, L3, L8 e L13 foram sacrificadas por decapitação e o músculo solear foi removido e processado para extração de RNA. Este RNA foi usado para avaliação da expressão do mRNA do GLUT4 por RTPCR (A). Os músculos solear (B) e plantares (C) de ratas CTL e L3 também foram processados para extração de proteínas de membranas totais seguida de western blot para detecção da proteína GLUT4. As barras representam as médias \pm EPM obtidas de três experimentos independentes. $* P<0.05$ vs. CTL. (n=3 a 4) 
Expressão e fosforilação em tirosina do receptor de insulina no músculo solear e plantares de ratas lactantes.

A habilidade da insulina em induzir fosforilação em resíduos de tirosina da subunidade $\beta$ de seu receptor (IR) foi maior no músculo solear de ratas L3 que de ratas CTL (1.58 vezes; p<0.05, Figura 20A). De maneira contrária ao músculo solear, a insulina induziu aumentos similares de fosforilação em tirosina de seu receptor em músculo plantares de ratas CTL e L3 (Figura 20B). Não apenas a fosforilação em resíduos de tirosina, mas também o conteúdo protéico do IR aumentou no músculo solear de ratas L3 quando comparados aos de ratas CTL (1.70 vezes; p<0.05) (Figura 20C). A expressão do IR no plantares não sofreu alteração durante a lactação (Figura 20D).

Expressão do IRS1 e do IRS2 e fosforilação em tirosina da pp185 no músculo solear e no plantares de ratas lactantes.

Após a sua ativação, o IR catalisa a fosforilação em tirosina de diversas proteínas intracelulares, entre elas o IRS1 e o IRS2. O IRS1 e o IRS2 migram na região do gel correspondente às proteínas de 165-185 kDa (pp185). Durante todo o período lactacional abordado neste estudo, a insulina induziu fosforilação em tirosina da pp185 de maneira semelhante no músculo solear e no plantares de ratas CTL e lactantes (respectivamente Figuras 21A e 21B). Também não foi observada alteração no conteúdo protéico do IRS1 e do IRS2 nos músculos solear (respectivamente Figuras 21C e 21E) e plantares (respectivamente Figuras 21D e 21F) de ratas lactantes em relação as ratas CTL. 

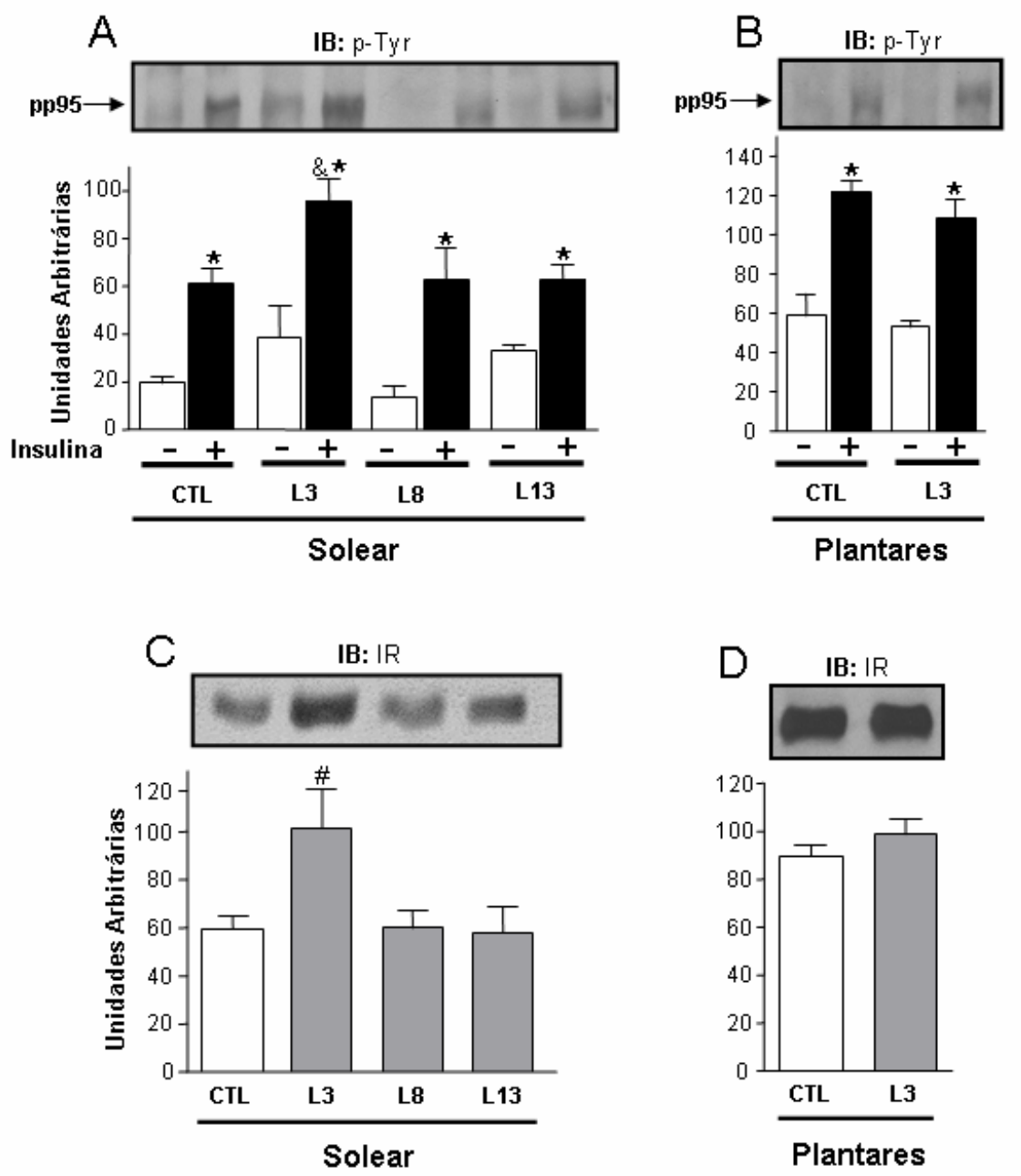

Figura 20: Expressão e fosforilação em tirosina do receptor de insulina no músculo solear e plantares de ratas lactantes. Ratas CTL, L3, L8 e L13 foram anestesiadas e o músculo solear foi removido (Basal barras brancas e cinzas). O plantares foi removido de ratas CTL e L3. A cavidade abdominal foi aberta e as ratas receberam injeção de insulina $\left(0.5 \mathrm{~mL} \mathrm{a} 10^{-5} \mathrm{M}\right)$ na veia cava. Após noventa segundos o músculo solear e plantares da outra pata foram removidos (Estimulado - barras pretas). O solear e plantares foram processados para western blot para detecção de fosfo-Tyr, respectivamente (A) e (B) e para detecção do receptor de insulina, respectivamente $(\mathbf{C})$ e (D). As barras representam as médias \pm EPM. $* P<0,05$ vs. basal dentro do mesmo grupo; $\& P<0,05$ vs. CTL estimulado; \# $P<0,05$ vs. CTL basal. (n=4 a 8 ) 

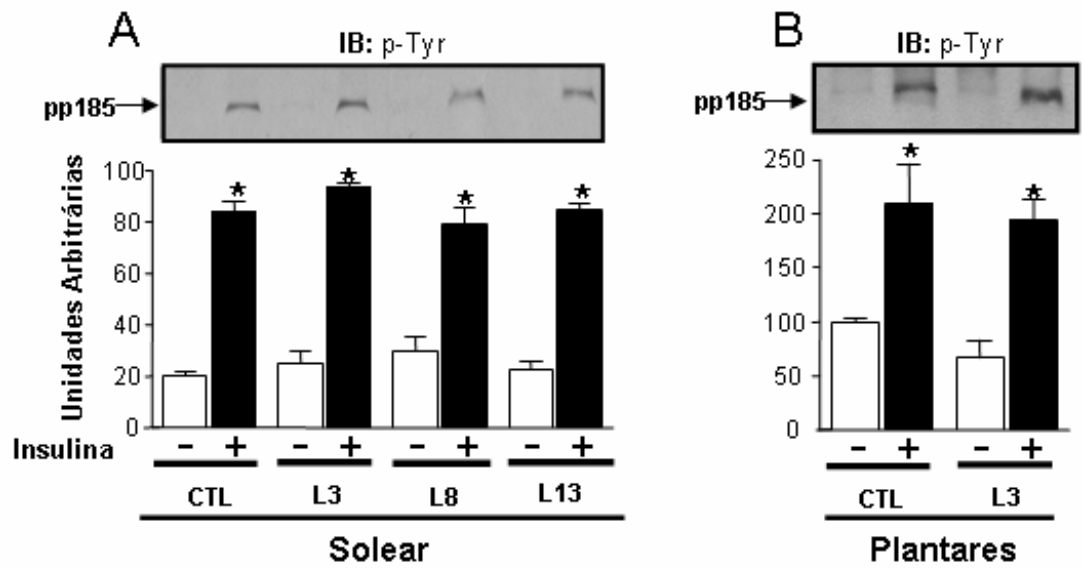

C

IB: IRS1

Plantares

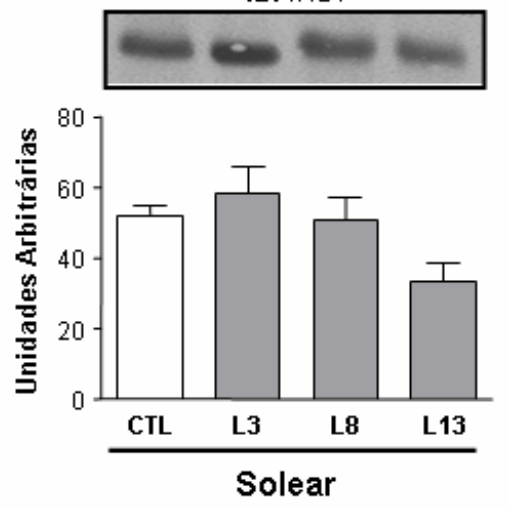

$\mathrm{D}$

IB: IRS1
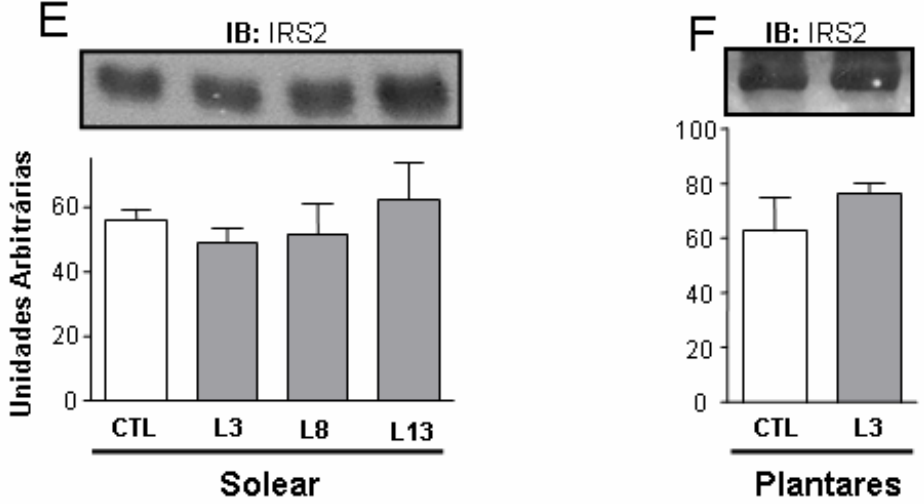

Figura 21: Expressão do IRS1 e IRS2 e fosforilação da pp185 em tirosina no músculo solear e no plantares de ratas lactantes. Ratas CTL, L3, L8 e L13 foram anestesiadas e o músculo solear foi removido (Basal - barras brancas e cinzas). O plantares foi removido de ratas CTL e L3. A cavidade abdominal foi aberta e as ratas receberam injeção de insulina $\left(0.5 \mathrm{~mL}\right.$ a $\left.10^{-5} \mathrm{M}\right)$ na veia cava. Após noventa segundos o músculo solear e o plantares da outra pata foram removidos (Estimulado - barras pretas). Os tecidos foram processados para western blot para detecção de fosfo-Tyr, respectivamente (A) e (B), IRS1, respectivamente (C) e (D) e IRS2, respectivamente (E) e (F). As barras representam as médias \pm EPM. $* P<0,05$ vs. basal dentro do mesmo grupo. (n=4 a 8 ) 
Fosforilação em tirosina do IRS1 e do IRS2 e associação com a PI3K no músculo solear de ratas lactantes.

Como IRS1 e IRS2 são os principais alvos do IR de fosforilação em resíduos de tirosina mas não observamos diferença na fosforilação em tirosina da pp185, adotamos a técnica de imunoprecipitação. Após imunoprecipitação avaliamos a fosforilação específica do IRS1 e do IRS2 e suas associações com a PI3K. A Figura 22A mostra que a fosforilação em tirosina do IRS1 estimulada por insulina é similar no músculo solear de ratas CTL e L3. Já a fosforilação em tirosina do IRS2 estimulada por insulina é maior no músculo solear de ratas L3 de que no grupo CTL (1.88 vezes; $p<0.05$, Figura 22B). O mesmo padrão observado na fosforilação em tirosina do IRS1 e do IRS2 no músculo solear de ratas lactantes foi encontrado na associação entre estas proteínas e a PI3K. A formação do complexo IRS1/PI3-K no músculo solear de ratas L3 é similar ao de ratas CTL (Figure 22C). Já a formação do complexo IRS2/PI3-K estimulada por insulina é maior em ratas L3 (2.00 vezes; $p<0.05$, Figura 22D).

Fosforilação em serina da AKT em músculo solear de ratas lactantes.

Apesar da atividade da PI3K ser um passo essencial para a captação de glicose estimulada por insulina, outras etapas da via de sinalização deste hormônio também são necessárias para a translocação de vesículas de GLUT4 para a membrana celular. Uma destas etapas consiste na ativação, através de fosforilação em resíduos de serina da proteína quinase AKT (PESSIN \& SALTIEL, 2000). A Figura 23 mostra que a fosforilação em serina da AKT estimulada pela insulina em solear de ratas L3 foi maior do que no músculo de ratas CTL (1.49 vezes vs. CTL; p<0.05). Em ratas L8 e L13, a fosforilação em serina da AKT estimulada pela insulina foi similar a observada em ratas CTL. 
A

IP: IRS-1 IB: p-Tyr
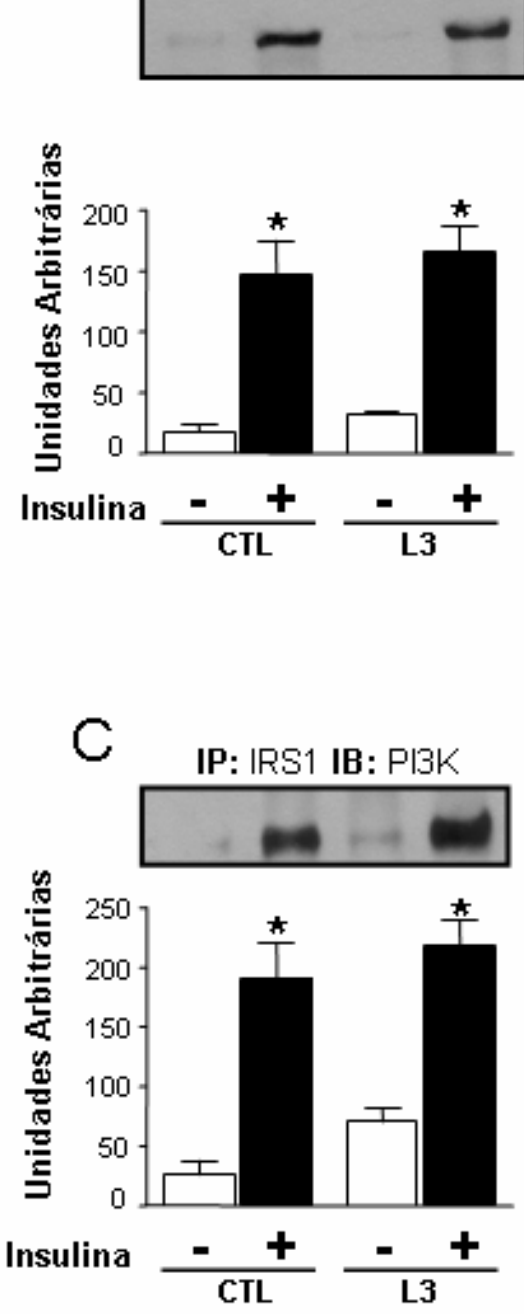

$\mathrm{B}$

IP: IRS-2 IB: p-Tyr
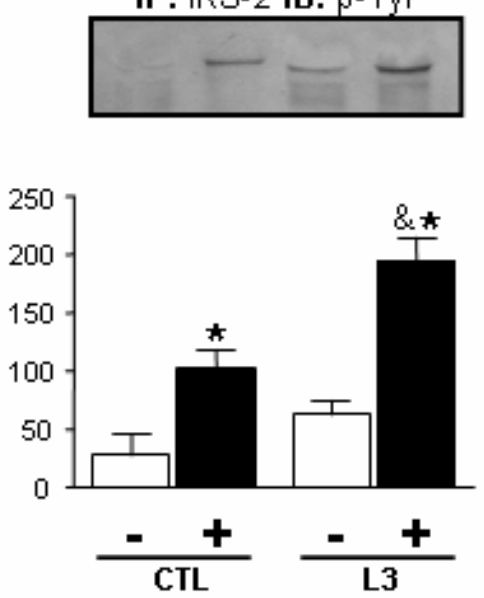

$\mathrm{D}$

IP: IRS2 IB: PI3K
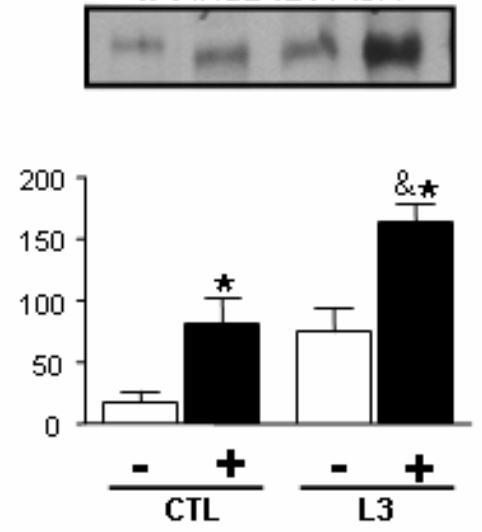

Figura 22: Fosforilação em tirosina do IRS1 e IRS2 e associação com a PI3K no músculo solear de ratas lactantes. Ratas CTL e L3 foram anestesiadas e o músculo solear foi removido (Basal - barras brancas). A cavidade abdominal foi aberta e as ratas receberam injeção de insulina $\left(0.5 \mathrm{~mL} \mathrm{a} 10^{-5} \mathrm{M}\right)$ na veia cava. Após noventa segundos o músculo solear da outra pata foi removido (Estimulado - barras pretas). Os tecidos foram processados para imunoprecipitação com anticorpo contra IRS1 e IRS2. Após separação no gel e transferência para a membrana, realizou-se western blot para detecção de fosfo-Tyr (p-Tyr), respectivamente (A) e (B), e PI3K, respectivamente (C) e (D). As barras representam as médias \pm EPM. $* P<0,05$ vs. basal dentro do mesmo grupo; $\& P<0,05$ vs. CTL estimulado. (n=3) 


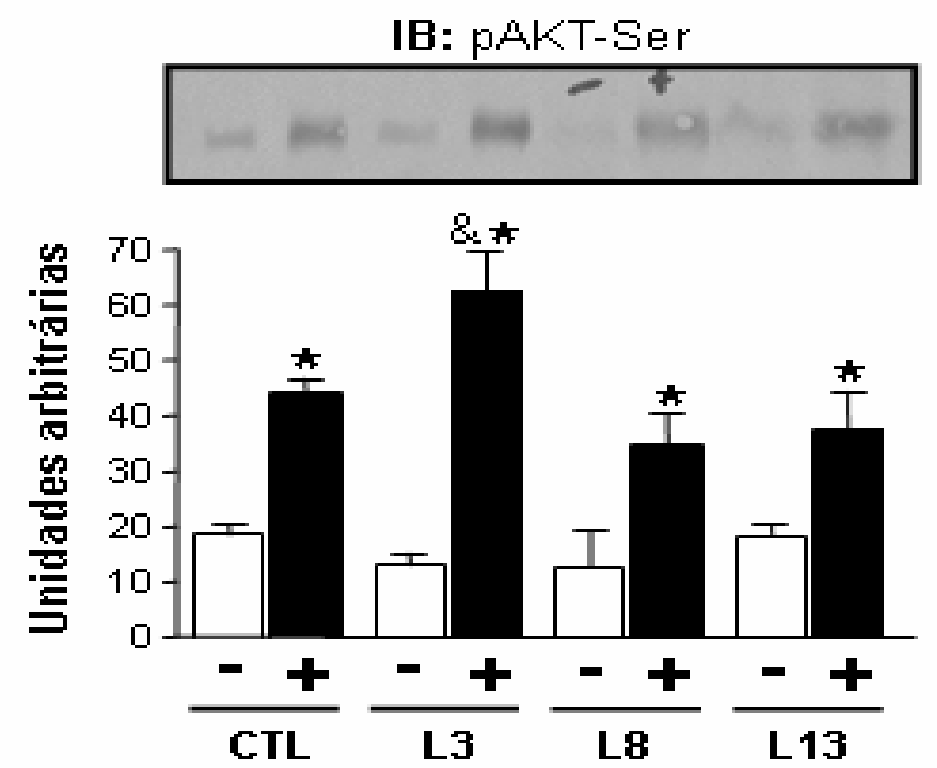

Figura 23: Fosforilação em serina da AKT em músculo solear de ratas lactantes. Ratas CTL, L3, L8 e L13 foram anestesiadas e o músculo solear foi removido (Basal - barras brancas). A cavidade abdominal foi aberta e as ratas receberam injeção de insulina $\left(0.5 \mathrm{~mL}\right.$ a $\left.10^{-5} \mathrm{M}\right)$ na veia cava. Após noventa segundos o músculo solear da outra pata foi removido (Estimulado - barras pretas). As amostras foram processadas para western blot para detecção de AKT fosforilada (pAKT-Ser). As barras representam as médias \pm EPM. ${ }^{*} P<0,05$ vs. basal dentro do mesmo grupo; \& $P<0,05$ vs. CTL estimulado. $(\mathrm{n}=4)$

Expressão de PTP1B em músculo solear e plantares de ratas lactantes.

PTP1B é uma proteína com atividade tirosina fosfatase que tem sido apontada como uma reguladora negativa da sinalização da insulina (STOKER, 2005). A Figura 24A mostra que o músculo solear de ratas L3 apresenta menor expressão de PTP1B que o de ratas CTL (0.17 vezes vs. CTL; p<0.05). A expressão de PTP1B retorna para valores similares aos do CTL em L8 e L13. Ao contrário do músculo solear, o plantares não apresenta variação da expressão de PTP1B em L3 (Figura 24B). 

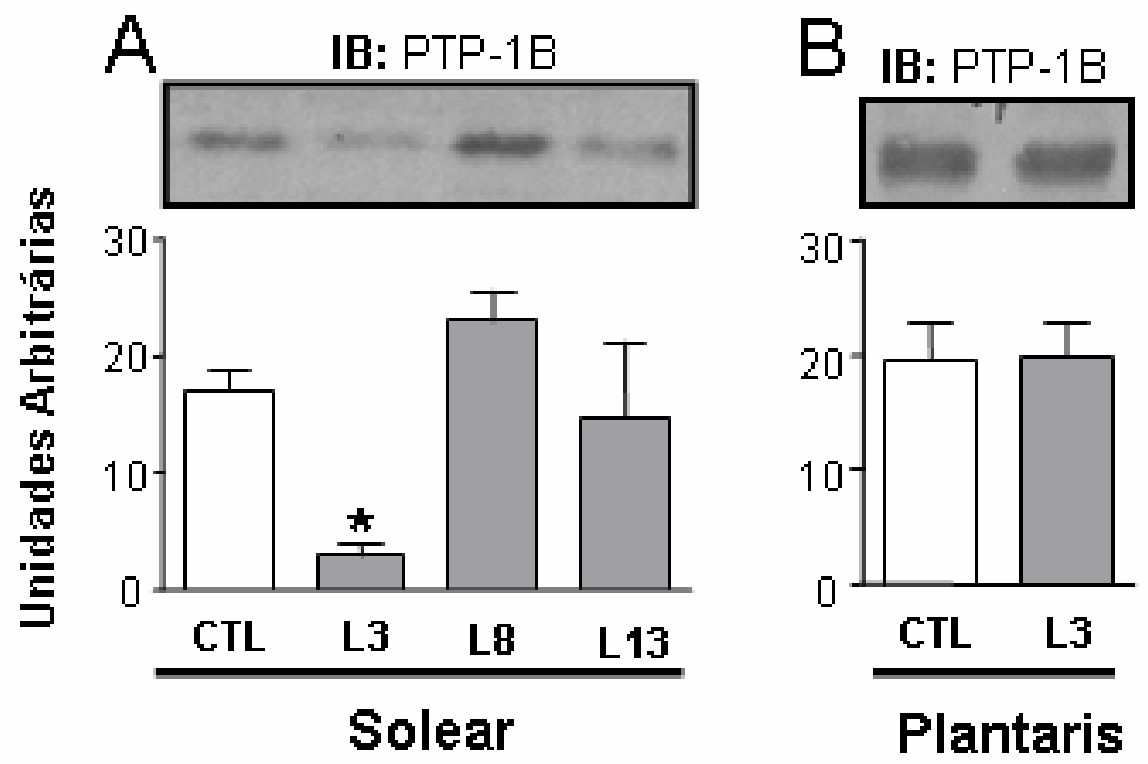

Figura 24: Expressão da PTP1B em músculo solear e plantares de ratas lactantes. Ratas CTL, L3, L8 e L13 foram anestesiadas e o músculo solear foi removido. O plantares foi removido de ratas CTL e L3. As amostras foram processadas para western blot para detecção de PTP1B em músculo solear (A) e plantares $(\mathbf{B})$. As barras representam as médias \pm EPM. ${ }^{*} P<0,05$ vs. CTL. $(\mathrm{n}=4$ a 8$)$ 
5. DISCUSSÃO 


\section{Discussão}

Stuebe e colaboradores demonstraram recentemente que mães que amamentavam seus filhos por longos períodos (até dois anos) apresentavam uma incidência menor de diabetes tipo 2. Este grupo concluiu que a lactação diminuía o risco de desenvolver diabetes tipo 2 através de um mecanismo que levava a melhora da homeostasia glicêmica independente do peso corporal (STUEBE et al., 2005). Considerando que as últimas projeções mundiais da Federação Internacional de Diabetes sugerem que atualmente 190 milhões de pessoas têm diabetes tipo 2, o aprofundamento do conhecimento dos mecanismos envolvidos no controle da homeostasia glicêmica durante a lactação poderá contribuir para o desenvolvimento de novas estratégias para tratar e prevenir esta doença.

Nosso trabalho iniciou esta abordagem aplicando o estudo de expressão gênica em larga escala em ilhotas de ratas no final da gestação. Estes experimentos mostraram uma regulação positiva de 56 genes e, dentre estes, o gene do STAT3. Este fator de transcrição também é regulado in vitro pela PRL (BORDIN et al., 2004a) e, por isto, foi nosso foco inicial no sentido de investigar os mecanismos envolvidos na adaptação do órgão produtor e secretor de insulina no periparto.

A fim de estudar o papel do STAT3 em um modelo cuja participação da PRL é fundamental, primeiramente determinamos a expressão e a fosforilação deste fator de transcrição em ilhotas isoladas de ratas grávidas (P19) e lactantes (L3 e L8). Considerando os resultados aqui mostrados e o achado prévio de nosso grupo de que a PRL aumenta a expressão de STAT3 em cultivo primário de ilhotas pancreáticas, é razoável afirmar que o aumento da expressão do STAT3 no final da gravidez e início da lactação se deve aos altos níveis circulantes de PRL. De acordo com esta proposição, 
Neilson e colaboradores demonstraram recentemente que a PRL induz ativação do STAT3 depois de um tratamento de 24 horas (NEILSON et al., 2007).

Esses resultados também indicam que a possível participação do STAT3 na fisiologia da ilhota durante a gravidez esteja relacionada aos seus altos níveis de fosforilação basal em resíduos de serina, e não à sua fosforilação em tirosina. Apesar da fosforilação em tirosina do STAT3 ser considerada um evento crucial para sua atividade transcricional (HEINRICH et al., 2003), a participação da fosforilação em serina ainda não está plenamente esclarecida. A maioria das evidências sugere que a fosforilação em serina do STAT3, que ocorre em sítio de ação da MAPK (Serina 727) tem uma relação positiva com sua atividade transcricional (SHEN et al., 2004). De fato, a ativação de proteínas pertencentes à família das ERKs (Extracellular signal-Regulated Kinases) leva à fosforilação em serina do STAT3 (KUROKI \& O'FLAHERTY, 1999; O'ROURKE \& SHEPHERD, 2002). Ilhotas cultivadas em presença de PRL (AMARAL et al., 2003) e ilhotas de ratas grávidas (AMARAL et al., 2004) apresentam um maior nível de fosforilação das ERK1/2, sugerindo um possível mecanismo pelo qual a PRL levaria a fosforilação em serina do STAT3.

GOROGAWA e colaboradores (2004) mostraram que a remoção da funcionalidade do gene do STAT3 em células $\beta$ pancreáticas resultou em um prejuízo da primeira fase de secreção de insulina estimulada pela glicose. É bem aceito que o manuseio do $\mathrm{Ca}^{2+}$ é um evento fundamental da regulação da secreção de insulina (HENQUIN, 2004). A diminuição da expressão e da atividade da SERCA tem sido descrita como uma característica de modelos animais de diabetes que apresentam prejuízo na secreção de insulina (ROE et al., 1994; VARADI et al., 1996; LEVY et al., 1998). Embora ambas as isoformas SERCA2 e SERCA3 sejam expressas em ilhotas de ratos e humanos e células RINm5F (VARADI et al., 1995), vários estudos atribuíram à 
SERCA3 uma participação central na disfunção da célula $\beta$ (ARREDOUANI et al., 2002b; BEAUVOIS et al., 2004). Entretanto, a ausência de SERCA3 é insuficiente para alterar a homeostasia glicêmica ou prejudicar a secreção de insulina (ARREDOUANI et al., 2002a). É importante ressaltar que a SERCA2, de maneira contrária a SERCA3, está envolvida na regulação do $\left[\mathrm{Ca}^{2+}\right]_{\mathrm{c}}$ de repouso na célula $\beta$, o que indica que a SERCA2 seja a principal $\mathrm{Ca}^{2+}$-ATPase de retículo em situações fisiológicas (VARADI \& RUTTER, 2002). De maneira concordante com nossos resultados, CREPIN e colaboradores (2007) demonstraram recentemente que a PRL induz a expressão de SERCA2 em células de epitélio prostático.

O perfil da dinâmica de secreção de insulina por ilhotas pancreáticas de ratas grávidas mostrou que ocorre um aumento na resposta secretora frente a concentrações estimuladoras de glicose. Esse resultado está de acordo com estudos clássicos realizados em ratas no final da gestação (GREEN \& TAYLOR, 1972; LIPSON \& SHARP, 1978). Os aumentos da primeira e da segunda fase de secreção são, no entanto, eventos que já não são observados no início da lactação. Além disto, a primeira fase de secreção de insulina está completamente suprimida em ilhotas de ratas L3. Já havia sido demonstrado anteriormente que a capacidade secretora do pâncreas endócrino retorna aos valores de uma rata virgem já no início da lactação (HUBINONT et al., 1986; KAWAI \& KISHI, 1999). Este padrão dinâmico de supressão da primeira fase de secreção é, no entanto, inédito.

Acredita-se que a retomada aos valores normais de secreção de insulina pelas ilhotas de ratas lactantes deva ocorrer como consequiência de uma rápida diminuição dos estoques intracelulares de cálcio (HUBINONT et al., 1986; HUBINONT \& MALAISSE, 1987). O aumento de SERCA2 - mas não de SERCA3 - em ilhotas de ratas grávidas, somada à rápida diminuição desta proteína em ilhotas de ratas lactantes, 
pode indicar um possível mecanismo pelo qual se dá a diminuição dos estoques intracelulares de cálcio em ilhotas pancreáticas de ratas na transição da gestação para a lactação. Esta hipótese é reforçada pela observação da supressão da primeira fase de secreção de insulina em ilhotas de ratas grávidas submetidas ao bloqueio farmacológico da SERCA. Desta maneira, este conjunto de resultados corrobora a postulação prévia de HUBINONT e MALAISSE (1987), que sugeria que a depleção dos estoques intracelulares de cálcio contribui para a menor capacidade secretora de ilhotas pancreáticas de ratas lactantes. Além disto, nossos resultados indicam que a redução dos estoques intracelulares de cálcio deva ocorrer em decorrência da redução da expressão de SERCA2, que deve afetar consideravelmente a primeira fase de secreção de insulina.

Observamos que o padrão de fosforilação em serina do STAT3 em ilhotas de ratas grávidas e lactantes é semelhante ao padrão de expressão da SERCA2 e não da SERCA3. Com o intuito de investigar se a ação da PRL na célula $\beta$ pancreática resultava em aumento da expressão da SERCA2 de maneira dependente do STAT3, examinamos a expressão de SERCA2 em células RINm5F tratadas com PRL e submetidas ao bloqueio do STAT3. Os resultados demonstraram que a PRL foi capaz de estimular a expressão de SERCA2 nestas células, evento este dependente da indução da expressão do STAT3. A repercussão do bloqueio da expressão de STAT3, e por consequiência da SERCA2, na secreção de insulina de ilhotas pancreáticas também foi estudada.

Nossos resultados mostram que a redução na expressão de STAT3, ao invés de diminuir, induz um aumento na secreção de insulina acumulada durante 1 hora de incubação na presença de altas concentrações de glicose. Este resultado está de acordo com os dados de secreção dinâmica de insulina de ilhotas de ratas P19 tratadas com inibidor farmacológico da SERCA. O tratamento de ilhotas de ratas P19 com 
thapsigargin resultou na supressão da primeira fase de secreção de insulina, mas promoveu uma tendência a aumentar a segunda fase.

Apesar de aparentemente contraditório, este resultado é corroborado por vários estudos que reportam que a inibição da SERCA resulta em um aumento da secreção de insulina estimulada por glicose (ARRREDOUANI et al. 2002a; ARREDOUANI. et al. 2002b; CRUZ-CRUZ et al., 2005; HUGHES, LEE \& TSE, 2006; BEAUVOIS et al., 2006). Além disto, em ilhotas isoladas de camundongos que não expressam SERCA3 (a isoforma predominante nesta espécie), a secreção de insulina cumulativa é maior do que aquela de animais wild type (ARRREDOUANI et al., 2002a). Desta maneira, nossa hipótese é a de que o bloqueio da expressão de STAT3 e SERCA2 pode diminuir a primeira fase de secreção de insulina (que corresponde a aproximadamente $2 \%$ do total de grânulos de insulina secretados em um ensaio cumulativo) e aumentar a segunda fase (que corresponde a aproximadamente a 98\% do total de grânulos de insulina secretados em um ensaio cumulativo). Isto explica o aumento na secreção acumulada em uma incubação de 1 hora e na presença de concentrações estimuladoras de glicose frente a inibição da expressão do STAT3 e por extensão, da SERCA2. A provável conseqüência deste fenômeno é a perda do ajuste fino da secreção de insulina frente a um desafio de altas concentrações de glicose, como o que ocorre no período pós-prandial.

Nossos resultados confirmam achados prévios, que descreveram que as perdas da capacidade secretora em ilhotas de camundongos $d b / d b$ está associada a menor atividade de SERCA (ROE et al., 1994). É importante ressaltar que os camundongos $d b / d b$ apresentam obesidade e diabetes tipo 2 devido à ausência de receptores funcionais para leptina, o principal ativador do STAT3 em células $\beta$ pancreáticas (KTORZA et al., 1997). 
A expressão de SERCA2 mediada pelo STAT3 aqui descrita mostra um novo mecanismo pelo qual a PRL deve regular positivamente a primeira fase da secreção de insulina em ilhotas de ratas grávidas. Desta maneira, a supressão da primeira fase de secreção de insulina em L3 parece estar relacionada à regulação negativa do STAT3 e da SERCA nas ilhotas destas ratas. A reversão da segunda fase de secreção de insulina observada no início da lactação deve, no entanto, resultar de outro mecanismo que medeie, possivelmente, o controle da massa e números de células $\beta$ e a expressão de proteínas que controlem a extrusão dos grânulos de insulina.

Enquanto ocorre um ganho de função no pâncreas endócrino mediado pela PRL durante a gestação, no início da lactação as ilhotas retornam ao estado normal. $\mathrm{O}$ aumento nos níveis circulantes de glicocorticóides, uma característica dos estágios finais da gestação, tem sido apontado como um importante fator que contribui para a redução da secreção de insulina estimulada por glicose, provavelmente por contraregular os efeitos da PRL (WEINHAUS et al., 2000; SHAO, QIAO \& FRIEDMAN, 2004). As ações dos glicocorticóides não são, no entanto, determinadas exclusivamente pelas suas concentrações circulantes ou por alterações séricas de suas proteínas carregadoras. Por exemplo, na obesidade idiopática não se observa alterações na concentração circulante de cortisol, mas sim em seu metabolismo intracelular (WAKE \& WALKER, 2004).

Duas isoenzimas pertencentes à classe 11ßHSD são essenciais para o metabolismo intracelular dos glicocorticóides. A 11ßHSD2 é uma desidrogenase dependente de $\mathrm{NAD}^{+}$que converte corticosterona no seu metabólito inativo cortisona. A expressão de 11ßHSD2 foi demonstrada em tecidos como rim, glândulas salivares e placenta (EDWARDS et al., 1988; FUNDER et al., 1988; STEWART et al., 1987). Esta enzima foi clonada em 1994 (ALBISTON et al., 1994), e mutações em seu gene têm 
sido apontadas como a causa da síndrome de excesso aparente de mineralocorticóide (SAME) (DAVE-SHARMA et al., 1998; MUNE et al., 1995). Deste modo, a redução na expressão de 11ßHSD2 em ilhotas pancreáticas de ratas L3 justifica uma ação exacerbada dos GCs neste momento da vida materna neste órgão, mesmo não havendo consenso sobre as concentrações circulantes de corticosterona neste momento da lactação. Por sua vez, a expressão de 11ßHSD2 não está aumenta em ilhotas de ratas P19, que já apresentam elevado níveis de corticosterona circulante. Assim, apenas a expressão desta enzima não explicaria o ganho de função do pâncreas endócrino no final da gestação.

A enzima 11ßHSD1 é uma redutase dependente de NADPH que regenera corticosterona ativa a partir de cortisona. A expressão de 11ßHSD1 está aumentada em ilhotas de ratos diabéticos, o que sugere uma relação entre maior ação de GCs no pâncreas endócrino destes animais e menor função secretora (DUPLOMB et al., 2004). De acordo com este trabalho, nos demonstramos no presente estudo que a expressão de 11ßHSD1 está diminuída em ilhotas de ratas P19, o que pode resultar em uma proteção intracelular contra os GCs durante a gravidez. Considerando conjuntamente os resultados da expressão de 11ßHSD1 e 11ßHSD2, é possível explicar como os GCs são responsáveis pela reversão das adaptações gestacionais do pâncreas endócrino materno logo no início do período lactacional. Assim, a variação de expressão destas enzimas esclarece um fenômeno in vivo que havia sido sugerido a partir de experimentos in vitro pelos grupos de Sorenson (WEINHAUS et al., 2000) e de Friedman (SHAO, QIAO \& FRIEDMAN, 2004).

A relação temporal evidente das ações da PRL e dos GCs sobre a expressão e fosforilação em serina do STAT3 e a expressão de SERCA2 em ilhotas de ratas grávidas e lactantes sugere uma inter-relação destes hormônios no controle da função do 
pâncreas endócrino nestas condições. Assim, a exemplo dos trabalhos que demonstraram a contra-regulação das ações gerais da PRL pelos GCs, nós investigamos os possíveis efeitos moleculares da adição de DEX ao tratamento in vitro com PRL em células RINm5F. Nossos experimentos revelaram que, em células RINm5F, DEX bloqueia totalmente o aumento da fosforilação em serina STAT3 e da expressão de SERCA2 induzidos por PRL, sem alterar a expressão do STAT3. DEX também bloqueia a ação da PRL sobre a expressão do mRNA da SERCA2 em ilhotas pancreáticas. Além disto, a DEX isoladamente diminui a fosforilação em serina do STAT3 e a expressão de SERCA2 em células RINm5F.

Em resumo, estes resultados esclarecem parte das perguntas levantadas no primeiro objetivo deste projeto e apontam para a regulação positiva da expressão e fosforilação em serina do STAT3 como um mecanismo responsável pelo aumento da expressão de SERCA2 em ilhotas de ratas grávidas e tratadas com PRL. Esta ação da PRL deve promover o aumento da primeira fase de secreção de insulina durante a gestação. Além disto, considerando-se os padrões de expressão de 11ß-HSD1 e $11 \beta-H S D 2$ in vitro e in vivo, sugerimos que e regulação negativa da fosforilação em serina do STAT3 e da expressão de SERCA em ilhotas de ratas L3 decorre da ação dos GCs, que deve ser um mecanismo que contribui para a supressão da primeira fase de secreção de insulina durante a lactação.

O aumento específico da fosforilação em serina do STAT3 nos levou a investigar as possíveis vias envolvidas neste fenômeno. A fosforilação em resíduos de serina do STAT3 já foi extensivamente demonstrada como um resultado da ativação das ERK 1/2 pela insulina (CERESA \& PESSIN, 1996; CERESA, HORVATH \& PESSIN, 1997) e citocinas como a eritropoetina (WIERENGA et al., 2003), IL-2 (FUNG, ROHWER \& MCGUIRE, 2003), leptina (O'ROURKE \& SHEPHERD, 2002) e GM- 
CSF (KUROKI \& O'FLAHERTY, 1999). Nossos resultados mostraram que, em concordância com dados previamente publicados (AMARAL et al., 2004), a fosforilação em resíduos de treonina e tirosina das ERK 1/2 estão aumentados em ilhotas de ratas P19. Além disto, nossos experimentos demonstram que em L3 há diminuição da fosforilação das ERK 1/2 para valores menores que os de ratas CTL. A fosforilação das ERK1/2, tal qual a fosforilação em serina do STAT3, foi regulada negativamente por DEX.

A fosforilação da AKT, proteína pertencente à outra via essencial para o crescimento da célula $\beta$ pancreática (TUTTLE et al., 2001), também está regulada positivamente em ratas P19, mas retorna a valores semelhantes aos de ratas CTL em L3 e não sofre uma modulação negativa absoluta por DEX. Devido ao padrão similar de fosforilação em ilhotas de ratas P19 e L3 e em células $\beta$ tratadas com DEX, a modulação fosforilação em serina do STAT3 pelos glicocorticóides deve ser consequência da regulação negativa da atividade das ERK $1 / 2$ e não pela via PI3K/AKT, apesar desta última já ter sido apontada como uma via responsável pela fosforilação da serina 727 do STAT3 (FUNG, ROHWER \& MCGUIRE, 2003).

As MAPK (Mitogen Activated Protein Kinases) são proteínas altamente conservadas que estão envolvidas em uma diversidade de processos celulares, tais como diferenciação e proliferação celular. As MAPKs são divididas em quatro famílias, dentre as quais a família das ERKs é considerada a família de MAPKs clássicas, que inclui as proteínas ERK1 e ERK2. As ERK 1/2 são ativadas por fosforilação em resíduos de treonina e tirosina por proteínas quinases denominadas MAPKK (Mitogen Activated Protein Kinase Kinase), e desativadas por desfosforilação nos resíduos de treonina ou em ambos os resíduos (KONDOH \& NISHIDA, 2006). Dentre as fosfatases específicas para resíduos de tirosina encontram-se a STEP (Protein-tyrosine 
phosphatase striatum-enriched) e a HePTP (Hematopoietic protein-tyrosine phosphatase); dentre as fosfatases de especificidade dupla (tirosina/treonina) encontram-se as MKPs (Mitogen Activated Protein Kinase Phosphatases) (KONDOH \& NISHIDA, 2006).

As MKPs são divididas em três famílias e são altamente específicas para as MAPKs, mas, de acordo com a família, diferem em quesitos como afinidade preferencial por um determinado tipo de MAPK, distribuição celular e regulação da atividade (FAROOQ \& ZHOU, 2004). A família de MKPs do tipo 1 é constituída por fosfatases constitutivamente nucleares e são estimuladas pelos mesmos agentes que ativam as MAPKs, e por isto são consideradas um importante mecanismo para regulação negativa da ativação desta via mitogênica. Nesta família encontram-se as MKP1 e 2 e a DUSP5 (Dual specificity protein phosphatase 5). A família de MAPKs do tipo 2 é constituída de fosfatases de localização citoplasmática e é composta pela MKP-3, MKP-4 e MKP-X. A família do tipo 3 é composta por fosfatases que desfosforilam somente as MAPKs JNK e p38, sem nenhum tipo de ação sobre as ERK 1/2 (KONDOH \& NISHIDA, 2006).

MKP-1 foi a primeira fosfatase de MAPK descrita e sua expressão gênica é controlada rapidamente após a exposição de células a fatores de crescimento (CHARLES, ABLER \& LAU, 1992). Esta fosfatase foi de especial interesse para nós pois sua cinética de expressão induzida em fibroblastos é temporalmente coincidente com a desativação das ERK 1/2 (SUN et al., 1993). Há evidências de que a MKP-1 também regula a JNK e a p38 (CHU et al., 1996; FRANKLIN \& KRAFT, 1997) mas parece que a MKP-2 é a fosfatase com atividade preferencial sobre a JNK (CADALBERT et al., 2005). A MKP-3 também foi descrita como uma fosfatase específica para as ERKs (MUDA et al., 1996). 
No presente estudo demonstramos que DEX aumenta a expressão de MKP-1 em células RINm5F. Este aumento também foi observado em ilhotas isoladas de ratas L3. Desta maneira sugerimos que, pela ação dos glicocorticóides, ocorre um aumento da expressão de MKP-1 em ilhotas de ratas no início da lactação, que resulta em uma diminuição da fosforilação das ERK 1/2. Este resultado é um achado inédito na célula $\beta$ pancreática, mas já foi demonstrado em uma série de estudos conduzidos em outros tipos celulares que DEX aumenta a expressão de MKP-1 (KASSEL et al. 2001; CHEN et al. 2002; LASA et al. 2002). Esta ação da DEX está diretamente envolvida na diminuição da atividade das ERK 1/2 e, consequentemente, da proliferação celular em osteoblastos (ENGELBRECHT et al., 2003). Assim, a ação negativa dos glicocorticóides sobre a atividade da ERK 1/2, possivelmente resultante do aumento da expressão de MKP-1 em ilhotas de ratas L3, deve se correlacionar com a diminuição da proliferação de células $\beta$ pancreáticas que ocorre logo após o parto, e que é responsável pela diminuição de massa das ilhotas neste período (SCAGLIA et al., 1995). A regulação negativa da fosforilação da ERK1/2 em ilhotas de ratas L3 e em células RINm5F tratadas com DEX também pode ter uma implicação direta na redução de secreção de insulina, uma vez que a ativação das ERK1/2 pela glicose leva a fosforilação de proteína envolvidas nos processos de exocitose de grânulos de insulina, tais com a sinapsina I (LONGUET et al., 2005).

Com base em nossos resultados, os mecanismos moleculares que propomos para explicar a adaptação da resposta secretora do pâncreas endócrino - e possivelmente da massa celular - que ocorre no organismo materno na transição entre gestação e lactação está ilustrado na Figura 25. 

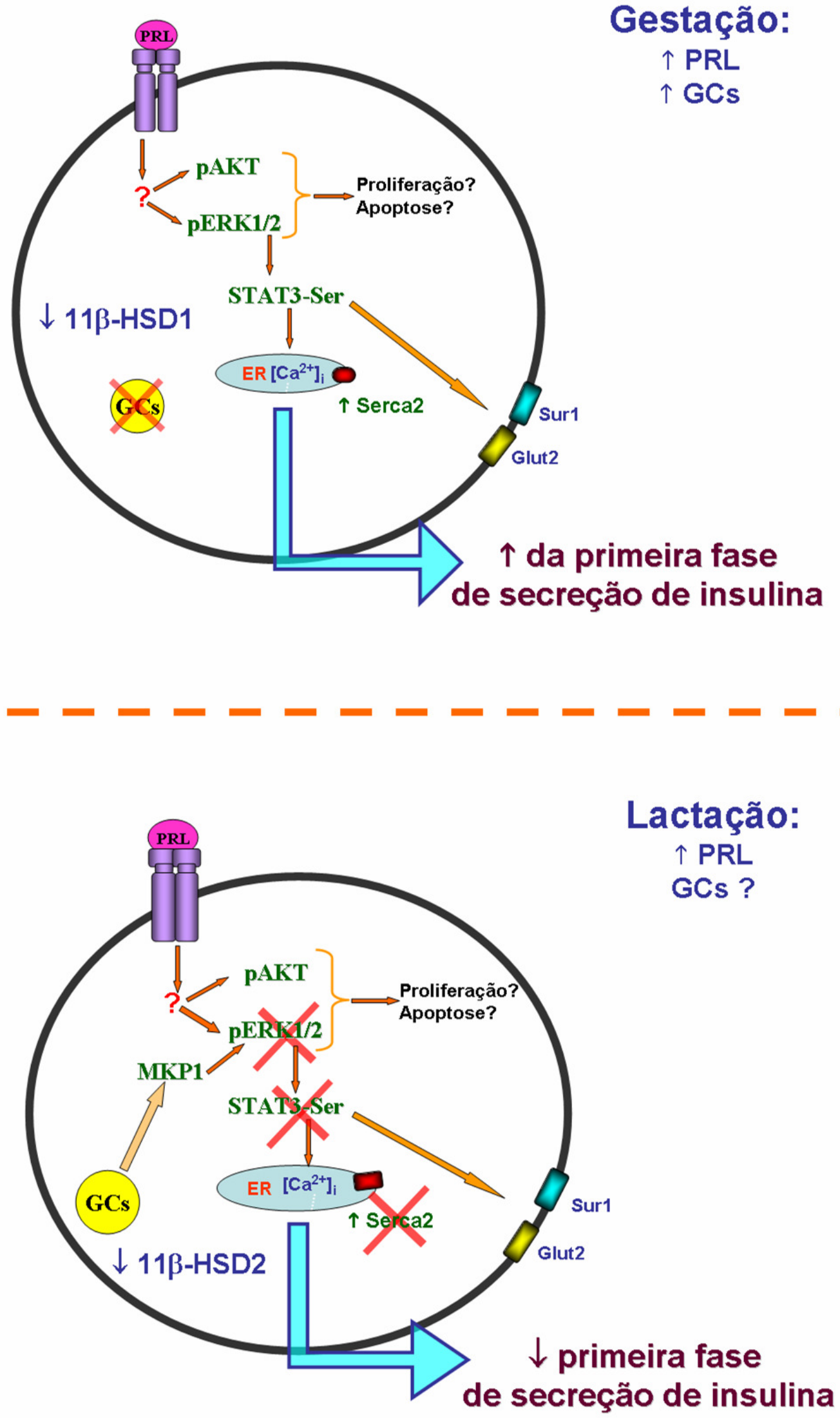

Figura 25: Esquema representativo dos mecanismos envolvidos na adaptação da ilhota pancreática durante a transição da gestação para a lactação 
Os resultados aqui apresentados até aqui sugerem mecanismos moleculares que resultam em adaptações das ilhotas pancreáticas no final da gestação, de modo a compensar a resistência à insulina. Estes mecanismos seriam regulados negativamente pelos GCs no início da lactação. Assim, tanto o aumento da secreção de insulina, como resultado do aumento do estoques intracelulares de $\mathrm{Ca}^{2+}$ decorrente da regulação da SERCA2 pelo STAT3, quanto o aumento da fosforilação das ERK 1/2 que levaria a um aumento da proliferação de células $\beta$ pancreáticas, estão temporalmente restritos à gestação. De acordo com nossos resultados, as ilhotas de ratas L3 apresentam uma secreção de insulina estimulada por glicose semelhante à de ratas CTL. Assim, a condição funcional do pâncreas endócrino no início da lactação é insuficiente para explicar a manutenção da homeostasia glicêmica neste período, que é, ademais, caracterizada por hipersensibilidade à ação da insulina. Com base neste problema, o passo seguinte deste estudo foi investigar as possíveis alterações na ação da insulina em tecidos responsivos ao hormônio no período lactacional.

Em 1986, Burnol e colaboradores demonstraram que o período de lactação é caracterizado pelo aumento da sensibilidade à insulina (BURNOL et al., 1986a). Este estudo utilizou a técnica do clamp hiperinsulinêmico euglicêmico em ratas lactantes entre 11 e 13 dias após o parto. Um estudo prévio deste mesmo grupo já sugeria, entretanto, que o aumento da sensibilidade à insulina poderia ocorrer no terceiro dia após o parto (BURNOL et al., 1983). De fato, a análise por ITT utilizada no presente trabalho demonstrou que ratas já apresentam hipersensibilidade a ação da insulina no terceiro dia de lactação. Desta maneira, a resistência à ação da insulina em ratas P19 é rapidamente alterada para um quadro oposto logo após o parto. Esta hipersensibilidade não é mais detectada uma semana após o término da lactação. 
Os músculos esqueléticos representam os maiores territórios de depuração da glicose após um estímulo intravenoso de insulina. Os tecidos musculares compostos predominantemente por fibras glicolíticas tais como o epitroclear e o extensor longo dos dedos apresentam uma captação de glicose estimulada por insulina reduzida no final da gestação (LETURQUE et al., 1986; SANCHO, KIM \& CARTEE, 2005) e, no caso do epitroclear, esta resposta diminuída ao hormônio também é detectável entre 11 e 13 dias após o parto (BURNOL et al., 1987).

O tecido adiposo, outro território importante para a depuração glicose estimulada pela insulina, também apresenta resistência à ação da insulina durante a gestação e lactação (BURNOL et al., 1986b; BURNOL et al., 1987; FERRE et al., 1986). Ao contrário do tecido adiposo e dos músculos compostos predominantemente por fibras glicolíticas, o músculo solear, composto predominantemente por fibras oxidativas, não apresenta resistência à ação da insulina no final da gestação (LETURQUE et al., 1981).

Por esta razão, e pelo fato de ser conhecida a maior responsividade à insulina dos músculos compostos predominantemente por fibras oxidativas em relação aos músculos predominantemente glicolíticos (SONG et al., 1999), o músculo solear foi escolhido como um possível candidato para o aumento da sensibilidade à insulina na lactação. De fato, nossos resultados mostraram que a captação máxima de glicose estimulada pela insulina e a produção de $\mathrm{CO}_{2}$ estão aumentadas no músculo solear isolado de ratas L3. Estas adaptações estão temporalmente limitadas ao início da lactação e indicam que este fenômeno deve ser essencial para a manutenção da homeostasia glicêmica logo após a perda do concepto. Com o decorrer da lactação, outros tecidos, tais como o glandular mamário, devem assumir um papel importante na depuração de glicose da corrente sanguínea do organismo materno. Em ratas ao redor do 
$11^{\circ}$ e $13^{\circ}$ dias de lactação, a fração de glicose captada pelas glândulas mamárias reapresentam grande parte do total de glicose depurada (WILLIAMSON, 1980).

Apesar das fibras glicolíticas corresponderem a aproximadamente $75 \%$ das fibras que compõem os músculos dos membros inferiores em ratos, o fluxo sanguíneo nos músculos compostos predominantemente por fibras oxidativas é de 3 a 4 vezes maior do que aquele dos músculos predominantemente glicolíticos (ARMSTRONG \& PHELPS, 1984). Desta maneira, o discreto aumento na captação de glicose estimulada por insulina no músculo solear de ratas L3, como observado em uma situação in vitro, deve tornar-se relevante para a depuração de glicose em uma situação crônica in vivo. Consequentemente, este fenômeno observado em um músculo oxidativo deve contribuir de maneira importante para o aumento de duas vezes na sensibilidade à insulina, observado através da análise de ITT em ratas L3.

Músculos compostos predominantemente por fibras oxidativas são mais susceptíveis aos efeitos de drogas sensibilizadoras da insulina e a condições patológicas que induzem resistência a ação deste hormônio. Isso foi demonstrado pela melhora na captação de glicose e na sinalização da insulina especificamente no músculo solear de ratos Zucker tratados com inibidores da GSK-3 (DOKKEN, SLONIGER \& HENRIKSEN, 2005; HENRIKSEN et al., 2003). Concordante com estes estudos, o presente trabalho descreve uma situação fisiológica em que a transição de um quadro de resistência para um quadro de hipersensibilidade à ação da insulina é caracterizada pelo aumento da resposta do músculo oxidativo à insulina. Uma possível explicação para esta maior susceptibilidade dos músculos oxidativos a situações que melhorem ou piorem a sensibilidade à insulina pode ser a maior expressão e/ou atividade de proteínas envolvidas na sinalização da insulina (SONG et al., 1999), bem como ao maior conteúdo de GLUT4 (HENRIKSEN et al., 1990) em relação aos músculos glicolíticos. 
Neste sentido, observamos uma maior expressão de GLUT4 no músculo solear de ratas L3 concomitantemente com uma diminuição desta proteína no músculo plantares (predominantemente glicolitico). Também observamos especificamente no músculo solear aumento da expressão e fosforilação de IR, aumento da fosforilação do IRS2 e da sua associação com a PI3K, aumento da fosforilação da AKT e diminuição da expressão da PTP1B.

Algumas das alterações moleculares detectadas no músculo solear de ratas L3 foram observadas em outros modelos, que também se caracterizam por aumento de sensibilidade à insulina. Por exemplo, ratos submetidos à restrição calórica apresentam aumento da atividade do receptor de insulina (ZHU et al., 2004), e o treinamento físico aumenta a expressão de GLUT4 (KIM, LEE \& KIM, 2004) e a fosforilação de AKT estimulada pela insulina (LUCIANO et al., 2002).

Um fato importante observado em nossos resultados é que a melhora da resposta à ação da insulina no músculo solear de ratas L3 é caracterizada por aumento da fosforilação em tirosina do IRS2, mas não do IRS1. Este aumento da fosforilação do IRS2 é acompanhado de um aumento de sua associação com a subunidade reguladora da PI3K após estímulo intravenoso de insulina. É importante ressaltar que a maioria dos trabalhos publicados a respeito da participação dos IRS na sinalização da insulina sugere que o IRS1 é o principal substrato do receptor de insulina no músculo esquelético, ou seja, sua ativação que resulta predominantemente na translocação de vesículas de GLUT4 para a membrana e conseqüente captação de glicose pela célula muscular (THIRONE, HUANG \& KLIP, 2006). Alguns estudos demonstraram, através do uso de RNA de interferência, que o bloqueio da expressão da expressão de IRS1 prejudica a captação de glicose estimulada pela insulina em células de linhagem 
muscular, fenômeno não observado após bloqueio da expressão do IRS2 (HUANG et al., 2005; BOUZAKRI et al., 2006).

A participação do IRS2 em uma situação de aumento da sensibilidade à ação da insulina em tecido muscular não é, no entanto, uma característica exclusiva da lactação. O aumento específico da associação do IRS2 com a PI3K é responsável, ainda que parcialmente, pela ação sensibilizadora induzida por uma sessão única de exercício em humanos e roedores (HOWLETT et al., 2002; HOWLETT et al., 2006). Além disso, um clássico estudo de Whiters e colaboradores demonstrou que camundongos sem IRS2 apresentam deterioração progressiva da homeostasia glicêmica, com resistência à insulina no fígado e no músculo (WHITERS et al., 1998).

Simultaneamente à regulação positiva da via IRS2/PI3K/AKT, nós encontramos uma redução da expressão de PTP-1B no músculo solear de ratas L3. É provável que a redução no conteúdo protéico deste fosfatase seja um dos fatores que favoreça esta regulação positiva da via da insulina no início da lactação. Esta hipótese é corroborada pelas características de situações inversas, onde se observou aumento da expressão desta fosfatase na resistência à insulina (GOLDSTEIN et al., 1998; AHMAD \& GOLDSTEIN, 1995). A exemplo das demais adaptações encontradas no músculo solear, a redução na expressão de PTP1B retornou aos valores encontrados em ratas CTL a partir do oitavo dia de lactação, o que não foi observado no plantares.

Apesar da participação dos diferentes tipos de músculos na resistência à insulina gestacional e da hipersensibilidade à insulina durante a lactação, não se pode excluir a participação determinante do território hepático nas adaptações metabólicas deste período. Estudos iniciais que se basearam na técnica de binding de receptor de insulina sugeriam que não havia resistência à insulina no fígado de ratas no final da gestação (DAVIDSON, 1984). No entanto, estudos de Girard e colaboradores demonstraram que, 
com a aplicação do clamp hiperinsulinêmico euglicêmico, o fígado apresenta menor resposta à insulina no final da gravidez (LETURQUE et al., 1984). Esta resistência correlaciona-se com menor atividade quinase do receptor de insulina (MARTÍNEZ et al., 1989), menor fosforilação em tirosina do IRS1 e menor formação do complexo IRS1/PI3K (SAAD et al., 1997). Em ruminantes, a gravidez cursa com uma maior produção hepática de glicose (BELL \& BAUMAN, 1997).

Durante a lactação de ratas, o tecido hepático, tal como as glândulas mamárias, apresenta uma maior capacidade de síntese de ácido graxos (VERNON \& FLINT, 1983). Esta alta capacidade lipogênica do fígado é potencializada com a remoção dos lactentes devido à supressão da produção de PRL, hormônio que induz a lipogênese preferencial no tecido mamário (AGIUS et al., 1979). No que diz respeito à supressão da produção hepática de glicose, o fígado de ratas lactantes é mais sensível à insulina que aqueles de ratas não virgens (BURNOL et al., 1986a). Considerando estes estudos e nossos resultados, podemos sugerir que a maior taxa de decaimento de glicose em ratas lactantes é resultado combinado de uma maior supressão da gliconeogênese hepática e uma maior captação de glicose pelo tecido muscular oxidativo frente a um estímulo de insulina.

A resistência gestacional à insulina é atribuída a uma complexa alteração hormonal. Em humanos, há fortes evidências de que os altos níveis de GH placentário exerçam uma ação determinante na resistência à insulina no final da gestação (FREEMARK, 2006). Este aumento nos níveis circulantes de GH no final da gestação também já foi detectado em ratos (CARLSSON, EDEN \& JANSSON, 1990; ESCALADA et al., 1997), mas ainda não está bem estabelecido se de origem placentária ou hipofisária. Além do GH, outros hormônios são candidatos importantes para o desencadeamento da resistência à insulina durante a gestação de ratos. A 
progesterona possui uma clara ação indutora de resistência à insulina em músculos isolados de ratos (LETURQUE et al., 1989). Ao contrário, a participação do lactogênio placentário ainda é controversa. Leturque e colaboradores demonstraram que o lactogênio placentário não interfere na ação da insulina em músculos isolados (LETURQUE et al., 1989), mas um estudo prévio de Ryan \& Enns sugere que tanto o lactogênio placentário como a PRL induzem resistência à insulina em tecido adiposo (RYAN \& ENNS, 1988). É pouco provável que o lactogênio placentário e a PRL exerçam uma ação determinante na resistência à insulina do músculo esquelético durante a gestação, na medida em que este tecido apresenta poucas cópias de mRNA que codificam a isoforma funcional do receptor de PRL (NAGANO \& Kelly, 1994). Além disto, os níveis circulantes de PRL permanecem altos no terceiro dia da lactação de ratos (KAWAI \& KISHI, 1999), e mesmo assim se observa um aumento na resposta do solear à insulina. Após o parto, ratas apresentam uma notável queda nos níveis circulantes de progesterona e GH que, já no terceiro dia de lactação, atingem valores semelhantes aos de uma rata não grávida (KAWAI \& KISHI, 1999; ESCALADA et al., 1997). É possível que esta rápida diminuição nos níveis de progesterona e GH contribuam para o aumento transiente na responsividade à insulina do músculo solear de ratas L3.

Em resumo, esta segunda parte de nosso trabalho demonstra que o aumento da resposta do músculo solear à insulina em ratas L3 deve contribuir para o aumento da sensibilidade à insulina no início da lactação. Esta adaptação é uma característica exclusiva dos músculos predominantemente oxidativos e coincide temporalmente com a regressão da capacidade secretora do pâncreas endócrino, sugerindo que alterações na ação da insulina são também centrais para a manutenção da homeostasia glicêmica materna no período pós-parto. 


\section{CONCLUSÕES}




\section{Conclusões}

1 - No terceiro dia de lactação ocorre uma diminuição da capacidade secretora do pâncreas endócrino materno, caracterizada por uma supressão da primeira fase de secreção de insulina. Esta mudança, no entanto, não gera na mãe nenhum tipo de intolerância à glicose, pois neste mesmo momento se estabelece um quadro de hipersensibilidade à insulina.

2 - O aumento da primeira fase da secreção de insulina no final da gestação deve ser dependente da capacidade da PRL de induzir a expressão de SERCA2 via STAT3, na medida em que o aumento da fosforilação em serina do STAT3 e o aumento da expressão de SERCA2 são eventos diretamente relacionados, modulados positivamente 'in vitro’ pela PRL e contra-regulados pelos glicocorticóides.

3 - A diminuição de expressão da enzima 11ß-HSD1 em ilhotas de ratas no final da gestação deve proteger este tecido da ação dos GCs neste período da vida materna. A ação dos GCs na ilhota pancreática de ratas lactantes deve estar facilitada pela diminuição da expressão da enzima 11 $\beta$-HSD2.

3 - Os glicocorticóides estimulam a expressão da fosfatase MKP-1 e consequentemente regulam negativamente a fosforilação das ERK $1 / 2$ em células $\beta$ pancreáticas. Este mecanismo deve estar envolvido na regressão das ilhotas de ratas grávidas ao estado basal, fenômeno que ocorre no início da lactação. 
4 - A hipersensibilidade à ação da insulina observada em ratas L3 se deve a uma melhora transiente e específica da resposta deste músculo oxidativo ao hormônio. Esta adaptação é acompanhada de aumento da expressão de GLUT4, IR e diminuição da expressão PTP1B. Também está envolvido nesta adaptação um aumento específico da fosforilação em tirosina do IRS2 e de sua associação com PI3K, levando a um aumento da fosforilação em serina da AKT. 
7. REFERÊNCIAS BIBLIOGRÁFICAS 


\section{Referências bibliográficas}

1. AGIUS, L.; ROBINSON, A. M.; GIRARD, J. R.; WILLIAMSON, D. H. Alterations in the rate of lipogenesis in vivo in maternal liver and adipose tissue on premature weaning of lactating rats: a possible regulatory role of prolactin. Biochem J, v. 15, p. 689-692, 1979.

2. AHMAD, F.; GOLDSTEIN, B. J. Alterations in specific protein-tyrosine phosphatases accompany insulin resistance of streptozotocin diabetes. Am J Physiol, v. 268, p. E932940, 1995.

3. AHRÉN, B. Type 2 diabetes, insulin secretion and beta-cell mass. Curr Mol Med, v. 5, p. 275-286, 2005.

4. AKERMAN, F.; LEI, Z.M.; RAO, C.V. Human umbilical cord and fetal membranes coexpress leptin and its receptor genes. Gynecological Endocrinol, v. 16, p. 299-306, 2002.

5. ALBISTON, A. L.; OBEYESEKERE, V. R.; SMITH, R. E.; KROZOWSKI, Z. S. Cloning and tissue distribution of the human 11 beta-hydroxysteroid dehydrogenase type 2 enzyme. Mol Cell Endocrinol, v. 105, p. R11-17, 1994.

6. AMARAL, M. E. C.; CUNHA, D. A.; ANHE, G. F.; UENO, M.; CARNEIRO, E. M.; VELlOSO, L. A.; BORDIN, S.; BOSCHERO, A. C. Participation of prolactin receptors and phosphatidylinositol 3-Kinase and MAP kinase pathways in the increase in pancreatic islet mass and sensitivity to glucose during pregnancy. Journal of Endocrinology, v. 183, p. 469-476, 2004.

7. AMARAL, M. E.; UENO, M.; CARVALHEIRA, J. B.; CARNEIRO, E. M.; VELLOSO, L. A.; SAAD, M. J.; BOSCHERO, A. C. Prolactin-signal transduction in neonatal rat pancreatic islets and interaction with the insulin-signaling pathway. Horm Metab Res, v. 35, p. 282-289, 2003.

8. ARMSTRONG, R. B.; PHELPS, R. O. Muscle fiber type composition of the rat hindlimb. Am J Anat, v. 171, p. 259-272, 1984.

9. ARREDOUANI, A.; GUIOT, Y.; JONAS, J. C.; LIU, L. H.; NENQUIN, M.; PERTUSA, J. A.; RAHIER, J.; ROLLAND, J. F.; SHULL, G. E.; STEVENS, M.; WUYTACK, F.; HENQUIN, J. C.; GILON, P. SERCA3 ablation does not impair insulin secretion but suggests distinct roles of different sarcoendoplasmic reticulum $\mathrm{Ca}(2+)$ pumps for $\mathrm{Ca}(2+)$ homeostasis in pancreatic beta-cells. Diabetes, v. 51, p. 3245-3253, 2002a.

10. ARREDOUANI, A.; HENQUIN, J. C.; GILON, P. Contribution of the endoplasmic reticulum to the glucose-induced $[\mathrm{Ca}(2+)](\mathrm{c})$ response in mouse pancreatic islets. Am J Physiol Endocrinol Metab, v. 282, p. E982-991, 2002b. 
11. ASHCROFT, F. M.; HARRISON, D. E.; ASHCROFT, S. J. Glucose induces closure of single potassium channels in isolated rat pancreatic beta-cells. Nature, v. 312, p. 446-448, 1984.

12. BEAUVOIS, M. C.; ARREDOUANI, A.; JONAS, J. C.; ROLLAND, J. F.; SCHUIT, F.; HENQUIN, J. C.; GILON, P. Atypical Ca2+-induced Ca2+ release from a sarcoendoplasmic reticulum $\mathrm{Ca} 2+-\mathrm{ATPase} 3$-dependent $\mathrm{Ca} 2+$ pool in mouse pancreatic beta-cells. J Physiol, v. 559, p. 141-156, 2004.

13. BEAUVOIS, M. C.; MEREZAK, C.; JONAS, J. C.; RAVIER, M. A.; HENQUIN, J. C.; GILON, P. Glucose-induced mixed [Ca2+]c oscillations in mouse beta-cells are controlled by the membrane potential and the SERCA3 Ca2+-ATPase of the endoplasmic reticulum. Am J Physiol Cell Physiol, v. 290, p. C1503-1511, 2006.

14. BELL, A. W.; BAUMAN, D. E. Adaptations of glucose metabolism during pregnancy and lactation. J Mammary Gland Biol Neoplasia, v. 2, p. 265-278, 1997.

15. BENDER, H. S.; CHICKERING, W. R. Pregnancy and diabetes: the maternal response. Life Sci, v. 37, p. 1-9, 1985.

16. BERG, M. N.; DHARMARAJAN, A. M.; WADDELL, B. J. Glucocorticoids and progesterone prevent apoptosis in the lactating rat mammary gland. Endocrinology, v. 143, p. 222-227, 2002.

17. BOLE-FEYSOT, C.; GOFFIN, V.; EDERY, M.; BINART, N.; KELLY, P. A. Prolactin (PRL) and its receptor actions.; signal transduction pathways and phenotypes observed in PRL receptor knockout mice. Endocrine Reviews, v. 19, p. 225-268, 1998.

18. BONORA, E.; MANICARDI, V.; ZAVARONI, I.; COSCELLI, C.; BUTTURINI, U. Relationships between insulin secretion.; insulin metabolism and insulin resistance in mild glucose intolerance. Diabetes Metab, v. 13, p. 116-121, 1987.

19. BORDIN, S.; AMARAL, M. E.; ANHE, G. F.; DELGHINGARO-AUGUSTO, V.; CUNHA, D. A.; NICOLETTI-CARVALHO, J. E.; BOSCHERO, A. C. Prolactinmodulated gene expression profiles in pancreatic islets from adult female rats. Mol Cell Endocrinol, v. 220, p. 41-50, 2004a.

20. BORDIN, S.; ANHÊ, G. F.; AMARAL, M. E.; MOTTA, R. S.; NOGUEIRA, T. C.; TORRÃO, A. S.; MARTINS, A. S.; CARVALHO, C. R.; CARPINELli, A. R.; BOSCHERO, A. C. Increased expression of several genes and phosphorylation of STAT3, ERK1/2 and AKT1 in pancreatic islets from pregnant rats." Molecular aspects of Pancreatic islet function, Mechanism of glucose sensing, Beta Cell Damage and Stem Cell Therapy, Prien/Chiemsee, Alemanha. Anual meeting of the EASD Islet Study Group; p. 36, 2004 b.

21. BORDIN, S.; BOSCHERO, A. C.; CARNEIRO, E. M.; ATWATER, I. Ionic mechanisms involved in the regulation of insulin secretion by muscarinic agonists. $\mathbf{J}$ Membr Biol, v. 148, p. 177-184, 1995. 
22. BOSCHERO, A. C.; CREPALDI, S. C.; CARNEIRO, E. M.; DELATTRE, E.; ATWATER, I. Prolactin induces maturation of glucose sensing mechanisms in cultured neonatal islets. Endocrinology, v. 133, p. 515-520, 1993.

23. BOUZAKRI, K.; ZACHRISSON, A.; AL-KHALILI, L.; ZHANG, B. B.; KOISTINEN, H. A.; KROOK, A.; ZIERATH, J. R. siRNA-based gene silencing reveals specialized roles of IRS-1/Akt2 and IRS-2/Akt1 in glucose and lipid metabolism in human skeletal muscle. Cell Metab, v. 4, p. 89-96, 2006.

24. BURNOL, A. F.; FERRE, P.; LETURQUE, A.; GIRARD, J. Effect of insulin on in vivo glucose utilization in individual tissues of anesthetized lactating rats. Am $\mathbf{J}$ Physiol, v. 252, p. E183-E188, 1987.

25. BURNOL, A. F.; GUERRE-MILLO, M.; LAVAU, M.; GIRARD, J. Effect of lactation on insulin sensitivity of glucose metabolism in rat adipocytes. FEBS Lett, v. 194, p. 292-296, 1986b.

26. BURNOL, A. F.; LETURQUE, A.; FERRE, P.; GIRARD, J. Glucose metabolism during lactation in the rat: quantitative and regulatory aspects. Am J Physiol, v. 245, p. E351-E358, 1983.

27. BURNOL, A. F.; LETURQUE, A.; FERRE, P.; KANDE, J.; GIRARD, J. Increased insulin sensitivity and responsiveness during lactation in rats. Am J Physiol, v. 251, p. E537-541, 1986a.

28. CADAlBERT, L.; SlOSS, C. M.; CAMERON, P.; PLEVIN, R. Conditional expression of MAP kinase phosphatase-2 protects against genotoxic stress-induced apoptosis by binding and selective dephosphorylation of nuclear activated c-jun $\mathrm{N}$ terminal kinase. Cell Signal, v. 17, p. 254-1264, 2005.

29. CAMPBELL, G. S.; ARGETSINGER, L. S.; IHLE, J. N.; KELLY, P. A.; RILLEMA, J. A.; CARTER-SU, C. Activation of JAK2 tyrosine kinase by prolactin receptors in $\mathrm{Nb} 2$ cells and mouse mammary gland explants. Proc Natl Acad Sci U S A, v. 91, p. 5232-5236, 1994.

30. CARDOZO, A. K.; ORTIS, F.; STORLING, J.; FENG, Y. M.; RASSCHAERT, J.; TONNESEN, M.; VAN EYLEN, F.; MANDRUP-POULSEN, T.; HERCHUELZ, A.; EIZIRIK, D. L.; Cytokines downregulate the sarcoendoplasmic reticulum pump Ca2+ ATPase $2 b$ and deplete endoplasmic reticulum $\mathrm{Ca} 2+$, leading to induction of endoplasmic reticulum stress in pancreatic beta-cells. Diabetes, v. 54, p. 452-461, 2005 .

31. CARLSSON, L.; EDEN, S.; JANSSON, J. O. The plasma pattern of growth hormone in conscious rats during late pregnancy. J Endocrinol, v. 124, p. 191-198, 1990.

32. CERASI, E.; LUFT, R. Plasma-insulin response to sustained hyperglycemia induced by glucose infusion in human subjects. Lancet, v. 2, p. 1359-1361, 1963.

33. CERESA, B. P.; HORVATH, C. M.; PESSIN, J. E. Signal transducer and activator of transcription-3 serine phosphorylation by insulin is mediated by a Ras/Raf/MEKdependent pathway. Endocrinology, v. 138, p. 4131-4137, 1997. 
34. CERESA, B. P.; PESSIN, J. E. Insulin stimulates the serine phosphorylation of the signal transducer and activator of transcription (STAT3) isoform. J Biol Chem, v. 271, p. 12121-12124, 1996.

35. CHAPMAN, R. S.; LOURENCO, P. C.; TONNER, E.; FLINT, D. J.; SELBERT, S.; TAKEDA, K.; AKIRA, S.; CLARKE, A. R.; WATSON, C. J. Suppression of epithelial apoptosis and delayed mammary gland involution in mice with a conditional knockout of Stat3. Genes Dev, v. 13, p. 2604-2616, 1999.

36. CHARLES, C. H.; ABLER, A. S.; LAU, L. F. cDNA sequence of a growth factorinducible immediate early gene and characterization of its encoded protein. Oncogene, v. 7, p. 187-190, 1992.

37. CHEN, P.; LI, J.; BARNES, J.; KOKKONEN, G. C.; LEE, J. C.; LIU, Y. Restraint of proinflammatory cytokine biosynthesis by mitogen-activated protein kinase phosphatase-1 in lipopolysaccharide-stimulated macrophages. J Immunol, v. 169, p. 6408-6416, 2002.

38. CHU, Y.; SOLSKI, P. A.; KHOSRAVI-FAR, R.; DER, C. J.; KELLY, K. The mitogen-activated protein kinase phosphatases PAC1.; MKP-1.; and MKP-2 have unique substrate specificities and reduced activity in vivo toward the ERK2 sevenmaker mutation. J Biol Chem, v. 271, p. 6497-6501, 1996.

39. CLARKSON, R. W.; WAYLAND, M. T.; LEE, J.; FREEMAN, T.; WATSON, C. J. Gene expression profiling of mammary gland development reveals putative roles for death receptors and immune mediators in post-lactational regression. Breast Cancer Res, v. 6, p. R92-R109, 2004.

40. COLlARES-BUZATO, C. B.; LEITE, A. R.; BOSCHERO, A. C. Modulation of gap and adherens junctional proteins in cultured neonatal pancreatic islets. Pancreas, v. 23, p. 177-185, 2001.

41. COSTES, S.; BROCA, C.; BERTRAND, G.; LAJOIX, A. D.; BATAILLE, D.; BOCKAERT, J.; DALLE, S. ERK1/2 control phosphorylation and protein level of cAMP-responsive element-binding protein: a key role in glucose-mediated pancreatic beta-cell survival. Diabetes, v. 55, p. 2220-2230, 2006.

42. CREPALDI, S. C.; CARNEIRO, E. M.; BOSCHEIRO, A. C. Long-term effect of prolactin treatment on glucose-induced insulin secretion in cultured neonatal rat islets.

Horm Metab Res, v. 29, p. 220-224, 1997.

43. CREPIN, A.; BIDAUX, G.; VANDEN-ABEELE, F.; DEWAILLY, E.; GOFFIN, V.; PREVARSKAYA, N.; SLOMIANNY, C. Prolactin stimulates prostate cell proliferation by increasing endoplasmic reticulum content due to SERCA $2 b$ overexpression. Biochem J, v. 401, p. 49-55, 2007.

44. CRUZ-CRUZ, R.; SALGADO, A.; SÁNCHEZ-SOTO, C.; VACA, L.; HIRIART, M. Thapsigargin-sensitive cationic current leads to membrane depolarization, calcium entry, and insulin secretion in rat pancreatic beta-cells. Am J Physiol Endocrinol Metab, v. 289, p. E439-445, 2005. 
45. CURRY, D. L.; BENNETT, L. L.; GRODSKY, G. M. Dynamics of insulin secretion by the perfused rat pancreas. Endocrinology, v. 83, p. 572-584, 1968.

46. DARNELL Jr, J. E. STATs and gene regulation. Science, v. 277, p. 1630-1635, 1997.

47. DAVE-SHARMA, S.; WILSON, R. C.; HARBISON, M. D.; NEWFIELD, R.; AZAR, M. R.; KROZOWSKI, Z. S.; FUNDER, J. W.; SHACKLETON, C. H.; BRADLOW, H. L.; WEI, J. Q.; HERTECANT, J.; MORAN, A.; NEIBERGER, R. E.; BALFE, J. W.; FATTAH, A.; DANEMAN, D.; AKKURT, H. I.; DE SANTIS, C.; NEW, M. I. Examination of genotype and phenotype relationships in 14 patients with apparent mineralocorticoid excess. J Clin Endocrinol Metab, v. 83, p. 2244-2254, 1998.

48. DAVIDSON, M. B. Insulin resistance of late pregnancy does not include the liver. Metabolism, v. 33, p. 532-537, 1984.

49. DE MAZANCOURT, P.; CARNEIRO, E. M.; ATWATER, I.; BOSCHERO, A. C. Prolactin treatment increases GLUT2 but not the G protein subunit content in cell membranes from cultured neonatal rat islets. FEBS Lett, v. 343, p. 137-140, 1994.

50. DICKSON, L. M.; LINGOHR, M. K.; MCCUAIG, J.; HUGL, S. R.; SNOW, L.; KAHN, B. B.; MYERS JR, M. G.; RHODES, C. J.; Differential activation of protein kinase $\mathrm{B}$ and $\mathrm{p} 70(\mathrm{~S} 6) \mathrm{K}$ by glucose and insulin-like growth factor 1 in pancreatic betacells (INS-1). J Biol Chem, v. 276, p. 21110-21120, 2001.

51. DICKSON, L. M.; RHODES, C. J.; Pancreatic beta-cell growth and survival in the onset of type 2 diabetes: a role for protein kinase B in the Akt? Am J Physiol Endocrinol Metab, v. 287, p. E192-198, 2004.

52. DOKKEN, B. B.; SLONIGER, J. A.; HENRIKSEN, E. J. Acute selective glycogen synthase kinase-3 inhibition enhances insulin signaling in prediabetic insulin-resistant rat skeletal muscle. Am J Physiol Endocrinol Metab, v. 288, p. E1188-E1194, 2005.

53. DUPLOMB, L.; LEE, Y.; WANG, M. Y.; PARK, B. H.; TAKAISHI, K.; AGARWAL, A. K.; UNGER, R. H. Increased expression and activity of 11 beta-HSD1 in diabetic islets and prevention with troglitazone. Biochem Biophys Res Commun, v. 313, p. 594-599, 2004.

54. EDWARDS, C. R.; STEWART, P. M.; BURT, D.; BRETT, L.; MCINTYRE, M. A.; SUTANTO, W. S.; DE KLOET, E. R.; MONDER, C. Localisation of 11 betahydroxysteroid dehydrogenase--tissue specific protector of the mineralocorticoid receptor. Lancet, v. 2, p. 986-989, 1988.

55. ELCHEBLY, M.; PAYETTE, P.; MICHALISZYN, E.; CROMLISH, W.; COLLINS, S.; LOY, A. L.; NORMANDIN, D.; CHENG, A.; HIMMS-HAGEN, J.; CHAN, C. C.; RAMACHANDRAN, C.; GRESSER, M. J.; TREMBLAY, M. L.; KENNEDY, B. P. Increased insulin sensitivity and obesity resistance in mice lacking the protein tyrosine phosphatase-1B gene. Science, v. 283, p. 1544-1548, 1999.

56. ENGELBRECHT, Y.; DE WET, H.; HORSCH, K.; LANGEVELDT, C. R.; HOUGH, F. S.; HULLEY, P. A. Glucocorticoids induce rapid up-regulation of mitogenactivated protein kinase phosphatase- 1 and dephosphorylation of extracellular signal- 
regulated kinase and impair proliferation in human and mouse osteoblast cell lines.

Endocrinology, v. 144, p. 412-422, 2003.

57. ESCALADA, J.; SANCHEZ-FRANCO, F.; VELASCO, B.; CACICEDO, L. Regulation of growth hormone $(\mathrm{GH})$ gene expression and secretion during pregnancy and lactation in the rat: role of insulin-like growth factor-I.; somatostatin.; and GHreleasing hormone. Endocrinology, v. 138, p. 3435-3443, 1997.

58. FANT, M.; MUNRO, H.; MOSES, A.C. An autocrine/paracrine role for insulin-like growth factors in the regulation of human placental growth. J Clin Endocrinol Metab, v. 63, p. 499-505, 1986.

59. FAROOQ, A.; ZHOU, M. M. Structure and regulation of MAPK phosphatases. Cell Signal, v. 16, p. 769-779, 2004.

60. FERRE, P.; BURNOL, A. F.; LETURQUE, A.; TERRETAZ, J.; PENICAUD, L.; JEANRENAUD, B.; GIRARD, J. Glucose utilization in vivo and insulin-sensitivity of rat brown adipose tissue in various physiological and pathological conditions. Biochem J, v. 233, p. 249-252, 1986.

61. FRANKLIN, C. C.; KRAFT, A. S. Conditional expression of the mitogen-activated protein kinase (MAPK) phosphatase MKP-1 preferentially inhibits p38 MAPK and stress-activated protein kinase in U937 cells. J Biol Chem, v. 272, p. 16917-16923, 1997.

62. FREEMARK, M. Regulation of maternal metabolism by pituitary and placental hormones: roles in fetal development and metabolic programming. Horm Res, v. 65, p. 41-49, 2006.

63. FRIEDRICHSEN, B. N.; RICHTER, H. E.; HANSEN, J. A.; RHODES, C. J.; NIELSEN, J. H.; BILLESTRUP, N.; MOLDRUP, A. Signal transducer and activator of transcription 5 activation is sufficient to drive transcriptional induction of cyclin D2 gene and proliferation of rat pancreatic ß-cells. Mol Endocrinol, v. 17, p. 945-958, 2003.

64. FUNDER, J. W.; PEARCE, P. T.; SMITH, R.; SMITH, A. I. Mineralocorticoid action: target tissue specificity is enzyme, not receptor, mediated. Science, v. 242, p. 583-585, 1988.

65. FUNG, M. M.; ROHWER, F.; MCGUIRE, K. L. IL-2 activation of a PI3K-dependent STAT3 serine phosphorylation pathway in primary human T cells. Cell Signal, v. 15, p. 625-636, 2003.

66. GALSGAARD, E. D.; GOUILLEUX, F.; GRONER, B.; SERUP, P.; NIELSEN, J. H.; BILLESTRUP, N. Identification of a growth hormone-responsive Stat5-binding element in the rat insulin 1 gene. Mol Endocrinol, v. 10, p. 652-660, 1996.

67. GALSGAARD, E. D.; NIELSEN, J. H.; MOLDRUP, A. Regulation of prolactin receptor (PRLR) gene expression in insulin-producing cells. Prolactin and growth hormone activate one of the rat prlr gene promoters via STAT5a and STAT5b. J Biol Chem, v. 274, p. 18686-18692, 1999. 
68. GILON, P.; ARREDOUANI, A.; GAILlY, P.; GROMADA, J.; HENQUIN, J. C. Uptake and release of $\mathrm{Ca}^{2+}$ by the endoplasmic reticulum contribute to the oscillations of the cytosolic $\mathrm{Ca}^{2+}$ concentration triggered by $\mathrm{Ca}^{2+}$ influx in the electrically excitable pancreatic ß-cell. J Biol Chem, v. 274, p. 20197-20205, 1999.

69. GOLDSTEIN, B. J.; AHMAD, F.; DING, W.; LI, P. M.; ZHANG, W. R. Regulation of the insulin signalling pathway by cellular protein-tyrosine phosphatases. Mol Cell Biochem, v. 182, p. 91-99, 1998.

70. GOLDSTEIN, B. J.; BITTNER-KOWALCZYK, A.; WHITE, M. F.; HARBECK, M. Tyrosine dephosphorylation and deactivation of insulin receptor substrate-1 by proteintyrosine phosphatase $1 \mathrm{~B}$. Possible facilitation by the formation of a ternary complex with the Grb2 adaptor protein. J Biol Chem, v. 275, p. 4283-4289, 2000.

71. GONZALEZ, C.; ALONSO, A.; FERNANDEZ, R.; PATTERSON, A. M. Regulation of insulin receptor substrate-1 in the liver, skeletal muscle and adipose tissue of rats throughout pregnancy. Gynecol Endocrinol, v. 17, p. 187-197, 2003.

72. GOROGAWA, S.; FUJITANI, Y.; KANETO, H.; HAZAMA, Y.; WATADA, H.; MIYAMOTO, Y.; TAKEDA, K.; AKIRA, S.; MAGNUSON, M. A.; YAMASAKI, Y.; KAJIMOTO, Y.; HORI, M. Insulin secretory defects and impaired islet architecture in pancreatic beta-cell-specific STAT3 knockout mice. Biochem Biophys Res Commun, v. 319, p. 1159-1170, 2004.

73. GREEN, I. C.; TAYLOR, K. W. Effects of pregnancy in the rat on the size and insulin secretory response of the islets of Langerhans. J Endocrinol, v. 54, p. 317-325, 1972.

74. GYSEMANS, C. A.; LADRIÈRE, L.; CALLEWAERT, H.; RASSCHAERT, J.; FLAMEZ, D.; LEVY, D. E.; MATTHYS, P.; EIZIRIK, D. L.; MATHIEU, C. Disruption of the gamma-interferon signaling pathway at the level of signal transducer and activator of transcription-1 prevents immune destruction of beta-cells. Diabetes, $v$. 54, p. 2396-2403, 2005.

75. HABENER, J. F.; KEMP, D. M.; THOMAS, M. K. Minireview: transcriptional regulation in pancreatic development. Endocrinology, v. 146, p. 1025-1034, 2005.

76. HEINRICH, P. C.; BEHRMANN, I.; HAAN, S.; HERMANNS, H. M.; MULLERNEWEN, G.; SCHAPER, F. Principles of interleukin (IL)-6-type cytokine signalling and its regulation. Biochem J, v. 374, p. 1-20, 2003.

77. HELLMAN, B. The islets of Langerhans in the rat during pregnancy and lactation, with special reference to the changes in the B/A cell ratio. Acta Obstet Gynecol Scand, v. 39, p. 331-342, 1960.

78. HENNEN, G.; FRANKENNE, F.; CLOSSET, J.; GOMEZ, F.; PIRENS, G.; el KHAYAT, N. A human placental GH: increasing levels during second half of pregnancy with pituitary GH suppression as revealed by monoclonal antibody radioimmunoassay. Int. J. Fertil, v. 30, p. 27-33, 1985.

79. HENQUIN, J. C. Pathways in beta-cell stimulus-secretion coupling as targets for therapeutic insulin secretagogues. Diabetes, v. 53, p. S48-58, 2004. 
80. HENRIKSEN, E. J.; BOUREY, R. E.; RODNICK, K. J.; KORANYI, L.; PERMUTT, M. A.; HOLLOSZY, J. O. Glucose transporter protein content and glucose transport capacity in rat skeletal muscles. Am J Physiol Endocrinol Metab, v. 259, p. E593E598, 1990.

81. HENRIKSEN, E. J.; KINNICK, T. R.; TEACHEY, M. K.; O'KEEFE, M. P.; RING, D.; JOHNSON, K. W.; HARRISON, S. D. Modulation of muscle insulin resistance by selective inhibition of GSK-3 in Zucker diabetic fatty rats. Am J Physiol Endocrinol Metab, v. 284, p. E892-E900, 2003.

82. HORNNES, P. J. On the decrease of glucose tolerance in pregnancy. A review. Diabetes Metab, v. 11, p. 310-315, 1985.

83. HOWLETT, K. F.; SAKAMOTO, K.; HIRSHMAN, M. F.; ASCHENBACH, W. G.; DOW, M.; WHITE, M. F.; GOODYEAR, L. J. Insulin signaling after exercise in insulin receptor substrate-2-deficient mice. Diabetes, v. 51, p. 479-483, 2002.

84. HOWLETT, K. F.; SAKAMOTO, K.; YU, H.; GOODYEAR, L. J.; HARGREAVES, M. Insulin-stimulated insulin receptor substrate-2-associated phosphatidylinositol 3kinase activity is enhanced in human skeletal muscle after exercise. Metabolism, v. 55, p. 1046-1052, 2006.

85. HUANG, C.; THIRONE, A. C.; HUANG, X.; KLIP, A. Differential contribution of insulin receptor substrates 1 versus 2 to insulin signaling and glucose uptake in 16 myotubes. J Biol Chem, v. 280, p. 19426-19435, 2005.

86. HUBINONT, C. J.; DUFRANE, S. P.; GARCIA-MORALES, P.; VALVERDE, I.; SENER, A.; MALAISSE, W. J. Influence of lactation upon pancreatic islet function. Endocrinology, v. 118, p. 687-694, 1986.

87. HUBINONT, C. J.; MALAISSE, W. J. Lactation-induced changes in calcium handling by rat pancreatic islets. J Dev Physiol, v. 9, p. 31-39, 1987.

88. HUGHES, E.; LEE, A. K.; TSE, A. Dominant role of sarcoendoplasmic reticulum $\mathrm{Ca} 2+-\mathrm{ATPase}$ pump in $\mathrm{Ca} 2+$ homeostasis and exocytosis in rat pancreatic beta-cells. Endocrinology, v. 147, p. 1396-1407, 2006.

89. HUNTER, T. Protein kinases and phosphatases: the yin and yang of protein phosphorylation and signaling. Cell, v. 80, p. 225-236, 1995.

90. KASSEL, O.; SANCONO, A.; KRATZSCHMAR, J.; KREFT, B.; STASSEN, M.; CATO, A. C. Glucocorticoids inhibit MAP kinase via increased expression and decreased degradation of MKP-1. EMBO J, v. 20, p. 7108-7116, 2001.

91. KAWAI, M.; KISHI, K. Adaptation of pancreatic islet B-cells during the last third of pregnancy: regulation of B-cell function and proliferation by lactogenic hormones in rats. Eur J Endocrinol, v. 141, p. 419-425, 1999.

92. KHOO, S.; GRIFFEN, S. C.; XIA, Y.; BAER, R. J.; GERMAN, M. S.; COBB, M. H. Regulation of insulin gene transcription by ERK1 and ERK2 in pancreatic beta cells. $\mathbf{J}$

Biol Chem, v. 278, p. 32969-32977, 2003. 
93. KIM, H. J.; LEE, J. S.; KIM, C. K. Effect of exercise training on muscle glucose transporter 4 protein and intramuscular lipid content in elderly men with impaired glucose tolerance. Eur J Appl Physiol, v. 93, p. 353-358, 2004.

94. KOMATSU, S.; YAMAMOTO, M.; ARISHIMA, K.; EGUCHI, Y. Maternal adrenocortical hormones maintain the early development of pancreatic B cells in the fetal rat. J Anat, v. 193, p. 551-557, 1998.

95. KONDOH, K.; NISHIDA, E. Regulation of MAP kinases by MAP kinase phosphatases. Biochim Biophys Acta, v. 1773, p. 1227-1237, 2006.

96. KRITIKOU, E. A.; SHARKEY, A.; ABELL, K.; CAME, P. J.; ANDERSON, E.; CLARKSON, R. W.; WATSON, C. J. A dual, non-redundant, role for LIF as a regulator of development and STAT3-mediated cell death in mammary gland. Development, v. 130, p. 3459-3468, 2003.

97. KTORZA, A.; BERNARD, C.; PARENT, V.; PENICAUD, L.; FROGUEL, P.; LATHROP, M.; GAUGUIER, D. Are animal models of diabetes relevant to the study of the genetics of non-insulin-dependent diabetes in humans? Diabetes Metab, v. 23, p. 38-46, 1997.

98. KULKARNI, R. N.; ROPER, M. G.; DAHLGREN, G.; SHIH, D. Q.; KAURI, L. M.; PETERS, J. L.; STOFFEL, M.; KENNEDY, R. T. Islet secretory defect in insulin receptor substrate 1 null mice is linked with reduced calcium signaling and expression of sarco(endo)plasmic reticulum Ca2+-ATPase (SERCA)-2b and -3. Diabetes, v. 53, p. 1517-1525, 2004.

99. KUROKI, M.; O'FLAHERTY, J. T. Extracellular signal-regulated protein kinase (ERK)-dependent and ERK-independent pathways target STAT3 on serine-727 in human neutrophils stimulated by chemotactic factors and cytokines. Biochem $\mathbf{J}, \mathrm{v}$. 341, p. 691-696, 1999.

100. LABRIOLA, L.; MONTOR, W. R.; KROGH, K.; LOJUDICE, F. H.; GENZINI, T.; GOLDBERG, A. C.; ELIASCHEWITZ, F. G.; SOGAYAR, M. C. Beneficial effects of prolactin and laminin on human pancreatic islet-cell cultures. Mol Cell Endocrinol, v. 263, p. 120-133, 2007.

101. LACY, P. E.; KOSTIANOVSKY, M. Method for the isolation of intact islets of Langerhans from the rat pancreas. Diabetes, v. 16, p. 35-39, 1967.

102. LAPPAS, M.; YEE, K.; PERMEZEL, M.; RICE, G.E. Release and regulation of leptin, resistin and adiponectin from human placenta, fetal membranes, and maternal adipose tissue and skeletal muscle from normal and gestational diabetes mellituscomplicated pregnancies. J Endocrinol, v. 186, p. 457-465, 2005.

103. LASA, M.; ABRAHAM, S. M.; BOUCHERON, C.; SAKLATVALA, J.; CLARK, A. R. Dexamethasone causes sustained expression of mitogen-activated protein kinase (MAPK) phosphatase 1 and phosphatase-mediated inhibition of MAPK p38. Mol Cell Biol, v. 22, p. 7802-7811, 2002. 
104. LETURQUE, A.; BURNOL, A. F.; FERRÉ, P.; GIRARD, J. Pregnancy-induced insulin resistance in the rat: assessment by glucose clamp technique. Am J Physiol, v. 246, p. E25-31, 1984.

105. LETURQUE, A.; FERRE, P.; BURNOL, A. F.; KANDE, J.; MAULARD, P.; GIRARD, J. Glucose utilization rates and insulin sensitivity in vivo in tissues of virgin and pregnant rats. Diabetes, v. 35, p. 172-177, 1986.

106. LETURQUE, A.; HAUGUEL, S.; SUTTER DUB, M. T.; MAULARD, P.; GIRARD, J. Effects of placental lactogen and progesterone on insulin stimulated glucose metabolism in rat muscles in vitro. Diabete Metab, v. 15, p. 176-181, 1989.

107. LETURQUE, A.; SATABIN, P.; FERRE, P.; GIRARD, J. R. Evidence that stimulation of glucose metabolism by insulin is not altered in isolated solear muscle of pregnant rats. Biochem J, v. 200, p. 181-184, 1981.

108. LEVY, J.; ZHU, Z.; DUNBAR, J. C. The effect of glucose and calcium on Ca2+adenosine triphosphatase in pancreatic islets isolated from a normal and a non-insulindependent diabetes mellitus rat model. Metabolism, v. 47, p. 185-189, 1998.

109. LINGOHR, M. K.; BUETTNER, R.; RHODES, C. J. Pancreatic beta-cell growth and survival--a role in obesity-linked type 2 diabetes? Trends Mol Med, v. 8, p. 375-384, 2002 .

110. LIPSON, L. G.; SHARP, G. W. Insulin release in pregnancy: studies on adenylate cyclase, phosphodiesterase, protein kinase, and phosphoprotein phosphatase in isolated rat islets of Langerhans. Endocrinology, v. 103, p. 1272-1280, 1978.

111. LIU, X.; RONINSON, G. W.; WAGNER, K. U.; GARRETT, L.; WYNSHAW-BORIS, A.; HENNIGHAUSEN, L. Stat5a is mandatory for adult mammary gland development and lactogenesis. Genes Dev, v. 11, p. 179-186, 1997.

112. LONGUET, C.; BROCA, C.; COSTES, S.; HANI, E. H.; BATAILLE, D.; DALLE, S. Extracellularly regulated kinases $1 / 2$ (p44/42 mitogen-activated protein kinases) phosphorylate synapsin I and regulate insulin secretion in the MIN6 beta-cell line and islets of Langerhans. Endocrinology, v. 146, p. 643-654, 2005.

113. LOW, S. C., CHAPMAN, K. E.; EDWARDS, C. R.; SECKL, J. R. 'Liver-type' 11 betahydroxysteroid dehydrogenase cDNA encodes reductase but not dehydrogenase activity in intact mammalian COS-7 cells. J Mol Endocrinol, v. 13, p. 167-174, 1994.

114. LUCIANO E.; CARNEIRO, E. M.; CARVALHO, C. R.; CARVALHEIRA, J. B.; PERES, S. B.; REIS, M. A.; SAAD, M. J.; BOSCHERO, A. C.; VELlOSO, L. A. Endurance training improves responsiveness to insulin and modulates insulin signal transduction through the phosphatidylinositol 3-kinase/Akt-1 pathway. Eur J Endocrinol, v. 147, p. 149-157, 2002.

115. MAGNATERRA, R.; PORZIO, O.; PIEMONTE, F.; BERTOLI, A.; SESTI, G.; LAURO, D.; MARLIER, L. N.; FEDERICI, G.; BORBONI, P. The effects of pregnancy steroids on adaptation of beta cells to pregnancy involve the pancreatic glucose sensor glucokinase. J Endocrinol, v. 155, p. 247-253, 1997. 
116. MARIE, J. C.; BAILBÉ, D.; GYLFE, E.; PORTHA, B. Defective glucose-dependent cytosolic $\mathrm{Ca} 2+$ handling in islets of $\mathrm{GK}$ and $\mathrm{nSTZ}$ rat models of type 2 diabetes. $\mathbf{J}$ Endocrinol, v. 169, p. 169-176, 2001.

117. MARKOFF, E.; BEATTIE, G. M.; HAYEK, A.; LEWIS, U. J. Effects of prolactin and glycosilated prolactin on (pro) insulin synthesis and insulin release from cultured rat pancreas islets. Pancreas, v. 5, p. 99-103, 1990.

118. MARTÍNEZ, C.; RUIZ, P.; ANDRÉS, A.; SATRÚSTEGUI, J.; CARRASCOSA, J. M. Tyrosine kinase activity of liver insulin receptor is inhibited in rats at term gestation. Biochem J, v. 263, p. 267-272, 1989.

119. MARYNISSEN, G.; AERTS, L.; VAN ASSCHE, F. A. The endocrine pancreas during pregnancy and lactation in the rat. J Dev Physiol, v. 5, p. 373-381, 1983.

120. MASHARANI, U.; KARAN, J. H. Pancreatic Hormones \& Diabetes Mellitus. In: Basic \& Clinical Endocrinology.; Sixth Edition. F.S Greenspan and D.G. Gardner (Eds). Lange Medical Books/McGraw-Hill.; 2001.; p. 623-698.

121. MORTON, N. M.; DE GROOT, R. P.; CAWTHORNE, M. A.; EMILSSON, V. Interleukin-1beta activates a short STAT-3 isoform in clonal insulin-secreting cells. FEBS Lett, v. 442, p. 57-60, 1999.

122. MUDA, M. .; THEODOSIOU, A.; RODRIGUES, N.; BOSCHERT, U.; CAMPS, M.; GILLIERON, C.; DAVIES, K.; ASHWORTH, A.; ARKINSTALL, S. The dual specificity phosphatases M3/6 and MKP-3 are highly selective for inactivation of distinct mitogen-activated protein kinases. J Biol Chem, v. 271, p. 27205-27208, 1996.

123. MUNE, T.; ROGERSON, F. M.; NIKKILÄ, H.; AGARWAL, A. K.; WHITE, P. C. Human hypertension caused by mutations in the kidney isozyme of 11 betahydroxysteroid dehydrogenase. Nat Genet, v. 10, p. 394-399, 1995.

124. MURPHY, V. E.; SMITH, R.; GILES, W. B.; CLIFTON, V. L. Endocrine regulation of human fetal growth: the role of the mother, placenta, and fetus. Endocr Rev, v. 27, p. 141-169, 2006.

125. NAGANO, M.; KELLY, P. A. Tissue distribution and regulation of rat prolactin receptor gene expression. Quantitative analysis by polymerase chain reaction. J Biol Chem, v. 269, p. 13337-13345, 1994.

126. NASIR, I.; KEDEES, M. H.; EHRLICH, M. E.; TEITELMAN, G. The role of pregnancy hormones in the regulation of Pdx-1 expression. Mol Cell Endocrinol, v. 233, p. 1-13, 2005.

127. NEILSON, L. M.; ZHU, J.; XIE, J.; MALABARBA, M. G.; SAKAMOTO, K.; WAGNER, K. U.; KIRKEN, R. A.; RUI, H. Coactivation of Janus Tyrosine Kinase (Jak)1 Positively Modulates Prolactin-Jak2 Signaling in Breast Cancer: Recruitment of ERK and Signal Transducer and Activator of Transcription (Stat) 3 and Enhancement of Akt and Stat5a/b Pathways. Mol Endocrinol, v. 21, p. 2218-2232, 2007. 
128. NIELSEN, J. H. Effects of growth hormone, prolactin, and placental lactogen on insulin content and release, and deoxyribonucleic acid synthesis in cultured pancreatic islets. Endocrinology, v. 110, p. 600-606, 1982.

129. NIELSEN, J. H.; GALSGAARD, E. D.; MOLDRUP, A.; FRIEDRICHSEN, B. N.; BILLESTRUP, N.; HANSEN, J. A.; LEE, Y. C.; CARLSSON, C. Regulation of betacell mass by hormones and growth factors. Diabetes, v. 50, p. S25-29, 2001.

130. OKAMOTO, M. M.; SUMIDA, D. H.; CARVALHO, C. R.; VARGAS, A. M.; HEIMANN, J. C.; SCHAAN, B. D.; MACHADO, U. F. Changes in dietary sodium consumption modulate GLUT4 gene expression and early steps of insulin signaling. Am J Physiol Regul Integr Comp Physiol, v. 286, p. R779-785, 2004.

131. OPPERMANN, U. C.; PERSSON, B.; JÖRNVALL, H. Function, gene organization and protein structures of 11beta-hydroxysteroid dehydrogenase isoforms. Eur J Biochem, v. 249, p. 355-360, 1997.

132. O'ROURKE, L.; SHEPHERD, P. R. Biphasic regulation of extracellular-signalregulated protein kinase by leptin in macrophages: role in regulating STAT3 Ser727 phosphorylation and DNA binding. Biochem J, v. 364, p. 875-879, 2002.

133. PARASKEVAS, S.; AIKIN, R.; MAYSINGER, D.; LAKEY, J. R.; CAVANAGH, T. J.; HERING, B.; WANG, R.; ROSENBERG, L. Activation and expression of ERK, JNK, and p38 MAP-kinases in isolated islets of Langerhans: implications for cultured islet survival. FEBS Lett, v. 455, p. 203-208, 1999.

134. PARSONS, J. A.; BRELJE, T. C.; SORENSON, R. L Adaptation of islets of Langerhans to pregnancy: increased islet cell proliferation and insulin secretion correlates with the onset of placental lactogen secretion. Endocrinology, v. 130, p. 1459-1466, 1992.

135. PAVLOVIC, D.; ANDERSEN, N. A.; MANDRUP-POULSEN, T.; EIZIRIK, D. L. Activation of extracellular signal-regulated kinase (ERK)1/2 contributes to cytokineinduced apoptosis in purified rat pancreatic beta-cells. Eur Cytokine Netw, v. 11, p. 267-274, 2000.

136. PESSIN, J. E.; SALTIEL, A. R. Signaling pathways in insulin action: molecular targets of insulin resistance. J Clin Invest, v. 106, p. 165-169, 2000.

137. PETERSEN, H. V.; JENSEN, J. N.; STEIN, R.; SERUP, P. Glucose induced MAPK signalling influences NeuroD1-mediated activation and nuclear localization. FEBS Lett, v. 528, p. 241-245, 2002.

138. RASSCHAERT, J.; LADRIÈRE, L.; URBAIN, M.; DOGUSAN, Z.; KATABUA, B.; SATO, S.; AKIRA, S.; GYSEMANS, C.; MATHIEU, C.; EIZIRIK, D. L. Toll-like receptor 3 and STAT-1 contribute to double-stranded RNA+ interferon-gammainduced apoptosis in primary pancreatic beta-cells. J Biol Chem, v. 280, p. 3398433991, 2005.

139. ROE, M. W.; PHILIPSON, L. H.; FRANGAKIS, C. J.; KUZNETSOV, A.; MERTZ, R. J.; LANCASTER, M. E.; SPENCER, B.; WORLEY, J. F 3RD.; DUKES, I. D. 
Defective glucose-dependent endoplasmic reticulum $\mathrm{Ca} 2+$ sequestration in diabetic mouse islets of Langerhans. J Biol Chem, v. 269, p. 18279-18282, 1994.

140. ROSSI, G. .; SHERWIN, R. S.; PENZIAS, A. S.; LAPACZEWSKI, P.; JACOB, R. J.; SHULMAN, G. I.; DIAMOND, M. P. Temporal changes in insulin resistance and secretion in 24-h-fasted conscious pregnant rats. Am J Physiol, v. 265, p. E845-851, 1993.

141. RYAN, E. A.; ENNS, L. Role of gestational hormones in the induction of insulin resistance. J Clin Endocrinol Metab, v. 67, p. 341-347, 1988.

142. SAAD, M. J.; MAEDA, L.; BRENELLI, S. L.; CARVALHO, C. R.; PAIVA, R. S.; VELLOSO, L. A. Defects in insulin signal transduction in liver and muscle of pregnant rats. Diabetologia, v. 40, p. 179-186, 1997.

143. SALMEEN, A.; ANDERSEN, J. N.; MYERS, M. P.; TONKS, N. K.; BARFORD, D. Molecular basis for the dephosphorylation of the activation segment of the insulin receptor by protein tyrosine phosphatase 1B. Mol Cell, v. 6, p. 1401-1412, 2000.

144. SALTIEL, A. R.; PESSIN, J. E. Insulin signaling pathways in time and space. Trends Cell Biol, v. 12, p. 65-71, 2002.

145. SANCHO, R.; KIM, J.; CARTEE, G. D. Decreased contraction-stimulated glucose transport in isolated epitrochlearis muscles of pregnant rats. J Appl Physiol, v. 98, p. 1021-1027, 2005.

146. SCAGLIA, L.; SMITH, F. E.; BONNER-WEIR, S. Apoptosis contributes to the involution of $\beta$ cell mass in the post partum rat pancreas. Endocrinology, v. 136, p. 5461-5468, 1995.

147. SHAFRIR, E. Animal models of non-insulin-dependent diabetes. Diabetes Metab Rev, v. 8, p. 179-208, 1992.

148. SHAO, J.; QIAO, L.; FRIEDMAN, J. E. Prolactin, progesterone, and dexamethasone coordinately and adversely regulate glucokinase and cAMP/PDE cascades in MIN6 beta-cells. Am J Physiol Endocrinol Metab, v. 286, p. E304-310, 2004.

149. SHEN, Y.; SCHLESSINGER, K.; ZHU, X.; MEFFRE, E.; QUIMBY, F.; LEVY, D. E.; DARNELL JE, J. R. Essential role of STAT3 in postnatal survival and growth revealed by mice lacking STAT3 serine 727 phosphorylation. Mol Cell Biol, v. 24, p. 407-419, 2004.

150. SHERIDAN, D. J.; ANAYA, P.; PARSONS, J. A.; SORENSON, R. L. Increased dye coupling in pancreatic islets from rats in late-term pregnancy. Diabetes, v. 37, p. 908911, 1988.

151. SHIBASAKI, T.; ODAGIRI, E.; SHIZUME K.; LING, N. Corticotropin-releasing factor-like activity in human placental extracts. J Clin Endocrinol Metab, v. 55, p. 384-386, 1982.

152. SNG, J. C.; TANIURA, H.; YONEDA, Y. A tale of early response genes. Biol Pharm Bull, v. 27, p. 606-612, 2004. 
153. SONG, X. M.; RYDER, J. W.; KAWANO, Y.; CHIBALIN, A. V.; KROOK, A.; ZIERATH, J. R. Muscle fiber type specificity in insulin signal transduction. Am J Physiol Regul Integr Comp Physiol, v. 277, p. R1690-R1696, 1999.

154. SORENSON, R. L.; BRELJE, T. C.; HEGRE, O. D.; MARSHALL, S.; ANAYA, P.; SHERIDAN, J. D. Prolactin (in vitro) decreases the glucose stimulation threshold, enhances insulin secretion, and increases dye coupling among islet B cells. Endocrinology, v. 121, p. 1447-1453, 1987.

155. STEWART, P. M.; WALLACE, A. M.; VALENTINO, R.; BURT, D.; SHACKLETON, C. H.; EDWARDS, C. R. Mineralocorticoid activity of liquorice: 11beta-hydroxysteroid dehydrogenase deficiency comes of age. Lancet, v. 2, p. 821-824, 1987.

156. STOCKLIN, E.; WISSLER, M.; GOUILLEUX, F.; GRONER, B. Functional interactions between Stat5 and the glucocorticoid receptor. Nature, v. 383, p. 726-728, 1996.

157. STOCKLIN, E.; WISSLER, M.; MORIGGLE, R.; GRONER, B. Specific DNA binding of Stat5, but not of glucocorticoid receptor, is required for their functional cooperation in the regulation of gene transcription. Mol Cell Biol, v. 17, p. 6708-6716, 1997.

158. STOKER, A. W. Protein tyrosine phosphatases and signalling. J Endocrinol, v. 185, p. 19-33, 2005.

159. STRAUB, S. G.; SHARP, G. W. Hypothesis: one rate-limiting step controls the magnitude of both phases of glucose-stimulated insulin secretion. Am J Physiol Cell Physiol, v. 287, p. C565-C571, 2004.

160. STUEBE, A. M.; RICH-EDWARDS, J. W.; WILLETT, W. C.; MANSON, J. E.; MICHELS, K. B. Duration of Lactation and Incidence of Type 2 Diabetes. JAMA, v. 294, p. 2601-2610, 2005.

161. SUN, H.; CHARLES, C. H.; LAU, L. F.; TONKS, N. K. MKP-1 (3CH134), an immediate early gene product, is a dual specificity phosphatase that dephosphorylates MAP kinase in vivo. Cell, v. 75, p. 487-493, 1993.

162. TEGLUND, S.; MCKAY, C.; SCHUETZ, E.; VAN DEURSEN, J. M.; STRAVOPODIS, D.; WANG, D.; BROWN, M.; BODNER, S.; GROSVELD, G.; IHLE, J. N. Stat5a and Stat5b proteins have essential and nonessential, or redundant, roles in cytokine responses. Cell, v. 93, p. 841-850, 1998.

163. TEITELMAN, G.; ALPERT, S.; HANAHAN, D. Proliferation, senescence, and neoplastic progression of beta cells in hyperplasic pancreatic islets. Cell, v. 52, p. 97$105,1988$.

164. THIRONE, A. C.; HUANG, C.; KLIP, A. Tissue-specific roles of IRS proteins in insulin signaling and glucose transport. Trends Endocrinol Metab, v. 17, p. 72-78, 2006. 
165. TUTTLE, R. L.; GILL, N. S.; PUGH, W.; LEE, J. P.; KOEBERLEIN, B.; FURTH, E. E.; POLONSKY, K. S.; NAJI, A.; BIRNBAUM, M. J. Regulation of pancreatic betacell growth and survival by the serine/threonine protein kinase Akt1/PKBalpha. Nat Med, v. 7, p. 1133-1137, 2001.

166. VARADI, A.; MOLNAR, E.; ASHCROFT, S. J. Characterisation of endoplasmic reticulum and plasma membrane $\mathrm{Ca}(2+)$-ATPases in pancreatic beta-cells and in islets of Langerhans. Biochim Biophys Acta, v. 1236, p. 119-127, 1995.

167. VARADI, A.; MOLNAR, E.; OSTENSON, C. G.; ASHCROFT, S. J. Isoforms of endoplasmic reticulum $\mathrm{Ca}(2+)$-ATPase are differentially expressed in normal and diabetic islets of Langerhans. Biochem J, v. 319, p. 521-752, 1996.

168. VARADI, A.; RUTTER, G. A. Dynamic imaging of endoplasmic reticulum Ca2+ concentration in insulin-secreting MIN6 Cells using recombinant targeted cameleons: roles of sarco(endo)plasmic reticulum $\mathrm{Ca} 2+-\mathrm{ATPase}$ (SERCA)-2 and ryanodine receptors. Diabetes, v. 51, p. S190-201, 2002.

169. VERNON, R. G.; FLINT, D. J. Control of fatty acid synthesis in lactation. Proc Nutr Soc, v. 42, p. 315-331, 1983.

170. WAKE DJ, WALKER BR. 11 beta-hydroxysteroid dehydrogenase type 1 in obesity and the metabolic syndrome. Mol Cell Endocrinol, v. 215, p. 45-54, 2004.

171. WANG, M. Y.; KOYAMA, K.; SHIMABUKURO, M.; MANGELSDORF, D.; NEWGARD, C. B.; UNGER, R. H. Overexpression of leptin receptors in pancreatic islets of Zucker diabetic fatty rats restores GLUT-2, glucokinase, and glucosestimulated insulin secretion. Proc Natl Acad Sci U S A, v. 95, p. 11921-11926, 1998.

172. WEBSTER, M. K.; GOYA, L.; GE, Y.; MAIYAR, A. C.; FIRESTONE, G. L. Characterization of sgk, a novel member of the serine/threonine protein kinase gene family which is transcriptionally induced by glucocorticoids and serum. Mol Cell Biol, v. 13, p. 2031-2040, 1993.

173. WEINHAUS, A. J.; BHAGROO, N. V.; BRELJE, T. C.; SORENSON, R. L. Dexamethasone counteracts the effect of prolactin on islet function: implications for islet regulation in late pregnancy. Endocrinology, v. 141, p. 1384-1393, 2000.

174. WEINHAUS, A. J.; BHAGROO, N. V.; BRELJE, T. C.; SORENSON, R. L. Role of cAMP in upregulation of insulin secretion during the adaptation of islets of Langerhans to pregnancy. Diabetes, v. 47, p. 1426-1435, 1998.

175. WEINHAUS, A. J.; STOUT, L. E.; BHAGROO, N. V.; BRELJE, T. C.; SORENSON, R. L. Regulation of glucokinase in pancreatic islets by prolactin: a mechanism for increasing glucose-stimulated insulin secretion during pregnancy. J Endocrinol, v. 193, p. 367-381, 2007.

176. WEINHAUS, A. J.; STOUT, L. E.; BRELJE, T. C.; SORENSON, R. L. Prolactin regulation of islet glucokinase: evidence for a functional Stat5 binding site in the Bcell glucokinase promoter. Diabetes, v. 50, p. A360, 2001. 
177. WEINHAUS, A. J.; STOUT, L. E.; SORENSON, R. L. "Glucokinase, Hexokinase, Glucose Transporter 2, and glucose metabolism in islets during pregnancy and prolactin-treated islets in vitro: mechanisms for long term up-regulation of islets". Endocrinology, v. 136, p. 1640-1649, 1996.

178. WIERENGA, A. T.; VOGELZANG, I.; EGGEN, B. J.; VELlENGA, E. Erythropoietin-induced serine 727 phosphorylation of STAT3 in erythroid cells is mediated by a MEK-, ERK-, and MSK1-dependent pathway. Exp Hematol, v. 31, p. 398-405, 2003.

179. WILLIAMSON, D. H. Integration of metabolism in tissues of the lactating rat. FEBS Lett, v. 117, p. K93-K105, 1980.

180. WITHERS, D. J.; BURKS, D. J.; TOWERY, H. H.; ALTAMURO, S. L.; FLINT, C. L.; WHITE, M. F. Irs-2 coordinates Igf-1 receptor-mediated beta-cell development and peripheral insulin signalling. Nat Genet, v. 23, p. 32-40, 1999.

181. WITHERS, D. J.; GUTIERREZ, J. S.; TOWERY, H.; BURKS, D. J.; REN, J. M.; PREVIS, S.; ZHANG, Y.; BERNAL, D.; PONS, S.; SHULMAN, G. I.; BONNERWEIR, S.; WHITE, M. F. Disruption of IRS-2 causes type 2 diabetes in mice. Nature, v. 391, p. 900-904, 1998 .

182. WOLLHEIM, C. B.; SHARP, G. W. Regulation of insulin release by calcium. Physiol Rev, v. 61, p. 914-973, 1981.

183. WREDE, C. E.; DICKSON, L. M.; LINGOHR, M. K.; BRIAUD, I.; RHODES, C. J. Protein kinase B/Akt prevents fatty acid-induced apoptosis in pancreatic beta-cells (INS-1). J Biol Chem, v. 277, p. 49676-49684, 2002.

184. WYSZOMIERSKI, S. L.; YEH, J.; ROSEN, J. M. Glucocorticoid receptor/signal transducer and activator of transcription (Stat5) interactions enhance Stat5 activation by prolonging Stat5 DNA binding and tyrosine phosphorylation. Mol Endocrinol, v. 13, p. 330-343, 1999.

185. ZHU, M.; DE CABO, R.; LANE, M. A.; INGRAM, D. K. Caloric restriction modulates early events in insulin signaling in liver and skeletal muscle of rat. Ann N Y Acad Sci, v. 1019, p. 448-452, 2004. 
8. ANEXOS 
Gabriel F. Anhê, Sandro M. Hirabara, Tatiana C. Turrer, Luciana C. Caperuto, Fernando F. Anhê, Luciene M. Ribeiro, Anderson C. Marçal, Carla R. O.

Carvalho, Rui Curi, Ubiratan F. Machado and Silvana Bordin

Am J Physiol Regulatory Integrative Comp Physiol 292:2225-2233, 2007. First published Mar 1, 2007; doi:10.1152/ajpregu.00902.2006

You might find this additional information useful...

This article cites 44 articles, 23 of which you can access free at:

http://ajpregu.physiology.org/cgi/content/full/292/6/R2225\#BIBL

Updated information and services including high-resolution figures, can be found at: http://ajpregu.physiology.org/cgi/content/full/292/6/R2225

Additional material and information about American Journal of Physiology - Regulatory, Integrative and Comparative Physiology can be found at:

http://www.the-aps.org/publications/ajpregu

This information is current as of September 17, 2007.

The American Journal of Physiology - Regulatory, Integrative and Comparative Physiology publishes original investigations that illuminate normal or abnormal regulation and integration of physiological mechanisms at all levels of biological organization, ranging from molecules to humans, including clinical investigations. It is published 12 times a year (monthly) by the American Physiological Society, 9650 Rockville Pike, Bethesda MD 20814-3991. Copyright @ 2005 by the American Physiological Society. ISSN: 0363-6119, ESSN: 1522-1490. Visit our website at http://www.the-aps.org/. 


\title{
Postpartum glycemic homeostasis in early lactating rats is accompanied by transient and specific increase of soleus insulin response through \\ IRS2/AKT pathway
}

\author{
Gabriel F. Anhê, Sandro M. Hirabara, Tatiana C. Turrer, Luciana C. Caperuto, \\ Fernando F. Anhê, Luciene M. Ribeiro, Anderson C. Marçal, \\ Carla R. O. Carvalho, Rui Curi, Ubiratan F. Machado, and Silvana Bordin \\ Department of Physiology and Biophysics, Institute of Biomedical Sciences, University of São Paulo, São Paulo, SP, Brazil \\ Submitted 27 December 2006; accepted in final form 28 February 2007
}

\begin{abstract}
Anhê GF, Hirabara SM, Turrer TC, Caperuto LC, Anhê FF, Ribeiro LM, Marçal AC, Carvalho CR, Curi R, Machado UF, Bordin S. Postpartum glycemic homeostasis in early lactating rats is accompanied by transient and specific increase of soleus insulin response through IRS2/AKT pathway. Am J Physiol Regul Integr Comp Physiol 292: R2225-R2233, 2007. First published March 1, 2007; doi:10.1152/ajpregu.00902.2006.-It is known that at the moment of delivery immediate lost of conceptus (main site of glucose disposal in late pregnancy) is not able to disturb glucose homeostasis in early lactating mothers. However, the mechanism by which this adaptation takes place in early lactation is still unknown. Most studies concerning insulin sensitivity in lactating rats were carried out at 11-13 days postpartum and did not describe functional changes in insulin response in early lactation. Here we show that lactation hypersensitivity to insulin is observed as early as 3 days after delivery (L3). We show that the oxidative soleus muscle displays a transient increased maximal insulin-induced glucose uptake and $\mathrm{CO}_{2}$ production, which is temporally limited to L3. Response of soleus muscle was accompanied by an increase in glucose transporter 4 (GLUT4) content at L3. This adaptive response was not detected in the glycolytic plantaris muscle, which displayed lower content of GLUT4. We also found that soleus muscle from early lactating rats have higher insulin receptor expression and tyrosine phosphorylation. Downstream steps of insulin signaling pathway; e.g., insulin receptor substrate 2 tyrosine phosphorylation and its association with phosphatidylinositol 3-kinase were also upregulated in soleus muscle. In parallel, protein tyrosine phosphatase 1B expression, a negative regulator of insulin signal, was reduced. Importantly, all of these molecular alterations were time limited to L3 and were not observed in plantaris muscle. These results suggest that improved insulin action in oxidative, but not in glycolytic muscle might contribute to achievement of glucose homeostasis postpartum.
\end{abstract}

soleus muscle; insulin signaling; insulin receptor substrate 2; murine thymoma viral oucogene

AT LATE PREGNANCY, THE GLUCOSE utilization rate of the conceptus represents $23 \%$ of maternal glucose utilization rate in the basal state and, under insulin stimulation, placental glucose utilization displays an additional increase of $30 \%$ (31). Additionally, this representative flux of glucose to the conceptus is also guaranteed by insulin resistance in adipose tissue (18) and skeletal muscles, particularly in those predominantly composed by glycolytic fibers (e.g., extensor digitorum longus and epitrochlearis) (31). In contrast, muscles that are predomi-

\footnotetext{
Address for reprint requests and other correspondence: S. Bordin, Prof. Lineu Prestes Av. 1524. São Paulo, SP, Brazil 05508-900 (e-mail: sbordin @icb.usp.br).
}

nantly oxidative (soleus) have a normal insulin response at late pregnancy (30).

Just after the delivery, glycemic homeostasis is maintained even without the presence of conceptus. Lower postabsorptive blood glucose concentrations and increased metabolic clearance rate of glucose are observed as early as 3 days of lactation (8). However, the mechanism underlying the adaptation of the maternal organism during the switch from an insulin resistance state (pregnancy) to a hypersensitivity (lactation) period, after the lost of the main target of glucose disposal, is not completely clarified.

Our question is raised mainly because most of the studies concerning insulin sensitivity in lactating rats were carried out at 11-13 days postpartum. This period is characterized as the peak of lactation in rats $(9-12)$, and the molecular changes that occur in insulin response during early lactation remain to be investigated. At the peak of lactation, an overall increase in insulin sensitivity is observed, and the mammary gland and liver display increased insulin sensitivity (9), while glucose uptake is reduced in white adipose tissue and the glycolytic muscle epitrochlearis (11).

Insulin stimulates glucose uptake in muscle and adipose cells by a well-characterized intracellular mechanism, which culminates with the translocation of glucose transporter 4 (GLUT4) vesicles to the cell surface. The serial events begin with the binding to and the activation of its cell surface transmembrane receptor, transmitting a signal that activates the tyrosine kinase domain of the $\beta$-subunit within the insulin receptor (IR). Once activated, the insulin receptor phosphorylates proteins that belong to the IR substrate (IRS) family 1-4. Tyrosine-phosphorylated IRS proteins became able to recognize and bind to the regulatory subunit of the phosphatidylinositol 3-kinase (PI3-kinase). Activation of PI3-kinase targets downstream activates AKT, an essential step for insulin-stimulated GLUT4 translocation. In addition to tyrosine phosphorylation, the insulin receptor and IRS proteins are also targeted by several protein tyrosine phosphatases (PTPases) that can downregulate insulin signal transmission. Two relevant PTPases that have been implicated in the negative regulation of the insulin signaling are PTP1B and leukocyte antigen-related (LAR) $(4,36)$ proteins.

Attempting to clarify the alterations in insulin action that occur to maintain glucose homeostasis in early lactation, the

\footnotetext{
The costs of publication of this article were defrayed in part by the payment of page charges. The article must therefore be hereby marked "advertisement" in accordance with 18 U.S.C. Section 1734 solely to indicate this fact.
} 
present work analyses the glucose metabolism and the key steps of insulin signaling during the entire period of lactation in soleus and plantaris skeletal muscles. Soleus was chosen as representative of the oxidative muscles $(\sim 87 \%$ of oxidative fibers) and plantaris was chosen as representative of the glycolytic muscles ( $\sim 91 \%$ of glycolytic fibers) (3).

\section{MATERIALS AND METHODS}

Reagents. The general chemical reagents were obtained from Synth (Diadema, São Paulo, Brazil). The apparatus for SDS-PAGE and electrotransfer, and the nitrocellulose membranes were from Bio-Rad (Hercules, CA). Tris, PMSF, aprotinin, dithiothreitol, luminol. and p-coumaric acid were from Sigma-Aldrich (St. Louis, MO). Sodium thiopental was purchased from Cristália (Itapira, São Paulo, Brazil) and regular insulin was from Biobrás (M. Claros, Minas Gerais, Brazil). [D-U- $\left.{ }^{14} \mathrm{C}\right]$ Glucose, and 2-deoxy-[D-2,6- $\left.{ }^{3} \mathrm{H}\right]$-glucose were from New England Nuclear Life Sciences (Boston, MA). Protein A Sepharose $6 \mathrm{MB}$ and the horseradish peroxidase (HRP)-conjugated anti-rabbit and anti-mouse antibodies were from Amersham-Pharmacia Biotech (Buckinghamshire, UK). Anti-IR, anti-IRS1, anti-IRS2, anti-phospho-Tyr and anti-PTP1B antibodies were from Santa Cruz Biotechnology (Santa Cruz, CA). Anti-PI3-kinase was from Upstate Biotechnology (Lake Place, NY). Phospho-AKT (Ser473) antibody was from New England BioLabs (Beverly, MA). X-ray-sensitive films and chemical developer were from IBF (Rio de Janeiro, Brazil). GoTaq DNA polymerase and ImProm-II Reverse Transcriptase were from Promega (Madison, WI). Random primers, dNTP set, agarose, and Trizol reagent were from Invitrogen (Carlsbad, CA). Primers for GLUT4 and RPL37a were synthesized by Integrated DNA Technologies (Coralville, IA).

Animals. Adult female Wistar rats at $8 \mathrm{wk}$ of age $(250-300 \mathrm{~g})$ were used in all experiments in accordance with the guidelines of the Brazilian College for Animal Experimentation. They were kept at $24^{\circ} \mathrm{C}$ with lights on from 7:00 AM to 7:00 PM. Standard chow and water were provided ad libitum. After being habituated to the experimental conditions, groups of two female rats each were housed with one male for 5 days. The presence of spermatozoa in the vaginal lavage indicated day 0 of gestation, and then the pregnant rats were isolated in a separate cage. On the day of the delivery, the number of pups was adjusted to 8 per lactating mother. After an overnight fast, the rats were anaesthetized with sodium thiopental $(5 \mathrm{mg} / 100 \mathrm{~g}$ body wt ip) and used for experimental procedures. Lactating rats were killed at 3 (L3), 8 (L8), 13 (L13) and 21 (L21) days postpartum. At 21 days after delivery, the pups were removed, and 7 days after the end of lactation (PL7) the rats were also used for intraperitoneal insulin tolerance test (ITT) experiments. Virgin age-matched rats were used as control group.

Intraperitoneal ITT. Insulin (2 IU/kg) was administered by intraperitoneal injection, and blood samples were collected from the tail at $0,5,10,15,20,25$, and $30 \mathrm{~min}$ for measurement of serum glucose. The constant rate for glucose disappearance $\left(K_{\mathrm{itt}}\right)$ was calculated using the formula $0.693 / t_{1 / 2}$. The glucose $t_{1 / 2}$ was calculated from the slope of the least-squares analysis of the plasma glucose concentrations during the linear decay phase (5).

Glucose metabolism in isolated soleus muscle from lactating rats. Soleus muscles were isolated and incubated as previously described (23). Rats were killed by cervical dislocation, and soleus muscles were rapidly and carefully isolated, split longitudinally in portions weighing 25 to $35 \mathrm{mg}$ and preincubated for $30 \mathrm{~min}$ at $37^{\circ} \mathrm{C}$ in Krebs-Ringer bicarbonate buffer pregassed for $30 \mathrm{~min}$ with $95 \%$ $\mathrm{O}_{2}-5 \% \mathrm{CO}_{2}$, containing $5.6 \mathrm{mM}$ glucose, $\mathrm{pH} 7.4$, with agitation at 120 $\mathrm{rpm}$. After this period, the muscles were transferred to other vials containing the same buffer, but $0.3 \mu \mathrm{Ci} / \mathrm{ml}\left[\mathrm{D}-\mathrm{U}-{ }^{14} \mathrm{C}\right]$-glucose, 0.2 $\mu \mathrm{Ci} / \mathrm{ml}$ 2-deoxy-[D-2,6- $\left.{ }^{3} \mathrm{H}\right]$-glucose and glucose $5.6 \mathrm{mM}$ were added. Incubation was then performed for $1 \mathrm{~h}$ under similar conditions, in the absence or presence of 0.1 or $10 \mathrm{mU} / \mathrm{ml}$ insulin. Phenylethylamine
( $0.3 \mathrm{ml}$ solution $1: 1$ in methanol) was added into a separate compartment to ${ }^{14} \mathrm{CO}_{2}$ adsorption for the analysis of $\left[\mathrm{D}-{ }^{14} \mathrm{C}\right]$-glucose oxidation. For determination of the extracellular space, some muscles were incubated in the presence of $0.1 \mu \mathrm{Ci} / \mathrm{ml}\left[\mathrm{L}-1{ }^{14} \mathrm{C}\right]$-glucose. After the incubation period, the muscles were briefly washed in saline at $4{ }^{\circ} \mathrm{C}$ and frozen in liquid $\mathrm{N}_{2} \cdot\left[{ }^{14} \mathrm{C}\right]$-glycogen synthesis (as estimated by $\left[\mathrm{D}-{ }^{14} \mathrm{C}\right]$-glucose incorporation into glycogen) was determined as described by Espinal et al. (17). 2-Deoxy-[D-2,6- $\left.{ }^{3} \mathrm{H}\right]$-glucose uptake was measured as previously described (24).

Immunoprecipitation and immunoblotting. After the loss of pedal reflex as an effect of anesthesia, one of the soleus and the plantaris hind limb muscles were removed and kept in dry ice. The abdominal cavity was opened, and the portal vein was exposed and injected with $0.5 \mathrm{ml}$ of a $10^{-5} \mathrm{M}$ insulin solution. After $90 \mathrm{~s}$, the remaining soleus and plantaris muscles were removed. The muscles were homogenized immediately in $\sim 10$ volume of extraction solubilization buffer in ice-cold bath by using a Polytron-Aggregate (Luzern, Switzerland) operated at maximum speed for $10 \mathrm{~s}$. The extracts were centrifuged at $12,000 \mathrm{~g}$ at $4^{\circ} \mathrm{C}$ for $30 \mathrm{~min}$ to remove insoluble material. The supernatant was either used for immunoprecipitation with anti-IRS1 or anti-IRS2 and protein A-Sepharose $6 \mathrm{MB}$ (for soleus samples) or treated as whole extract for immunoblotting as previously described (2). Similar-sized aliquots from whole extract tissue ( $75 \mu \mathrm{g}$ of protein) and the immunoprecipitated beads of Sepharose were treated with Laemmli sample buffer, subjected to SDS-PAGE and electrotransferred to nitrocellulose membranes in a semi-dry system for $60 \mathrm{~min}$ at $15 \mathrm{~V}$ (Bio-Rad). To reduce nonspecific protein binding to the nitrocellulose, the filter was preincubated overnight at $4^{\circ} \mathrm{C}$ in blocking buffer (5\% nonfat dry milk, $10 \mathrm{mM}$ Tris, $150 \mathrm{mM} \mathrm{NaCl}$ and $0.02 \%$ Tween 20). The nitrocellulose membranes were incubated for $4 \mathrm{~h}$ at $22^{\circ} \mathrm{C}$ with specific antibodies, as described in the figure legends, followed by 1-h incubation with a HRP-conjugated secondary antibody (1:10,000 in 1\% nonfat dry milk). Chemiluminescence reagents were used to visualize the autoradiogram, which was later exposed to photographic film. Quantitative analysis of blots was done using Scion Image software (Scion, Frederick, MD).

Membrane preparation for GLUT4 detection. Total membrane extracts from soleus and plantaris skeletal muscles were performed as previously described (35). Briefly, the muscles from control and L3 rats were homogenized by using a Polytron (Brinkmann Instruments, Westbury, NY) for $30 \mathrm{~s}$ at $4^{\circ} \mathrm{C}$ in $10 \mathrm{~mm}$ Tris $\cdot \mathrm{HCl}, 1 \mathrm{~mm}$ EDTA, and $250 \mathrm{~mm}$ sucrose, $\mathrm{pH} 7.4$, buffer. Homogenates were centrifuged at 700 $g$ at $4^{\circ} \mathrm{C}$ for $10 \mathrm{~min}$. The supernatants were transferred to a new tube, and the pellets were submitted to the same procedure one more time to assure a more efficient protein recovery. The two supernatants were

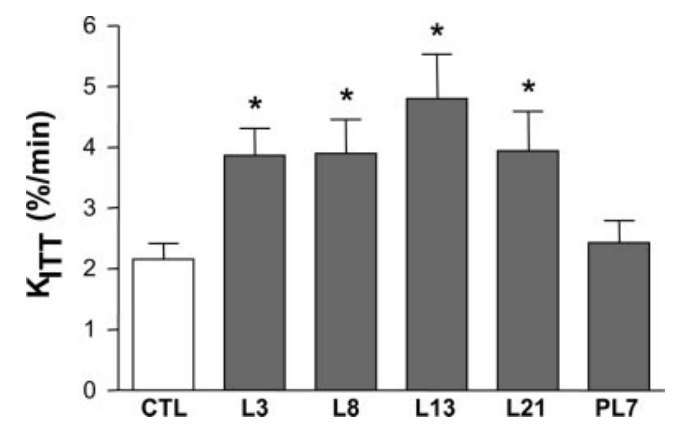

Fig. 1. Increased insulin sensitivity in lactating rats starts 3 days after delivery and returns to control (CTL) levels 7 days after lactation. Virgin (CTL), lactating rats at 3 (L3), 8 (L8), 13 (L13), and 21 (L21) days postpartum and 7 days after the end of lactation (PL7) received insulin ( $2 \mathrm{UI} / \mathrm{kg}$ ) by intraperitoneal injection and blood samples were collected from the tail at $0,5,10,15$, 20,25 , and $30 \mathrm{~min}$ for measurement of serum glucose. The constant rate for glucose disappearance $\left(K_{\text {itt }}\right)$ was calculated using the formula $0.693 / t_{1 / 2}$. The bars represent means $\pm \mathrm{SE}$ of $K_{\mathrm{it}}$ obtained from 6 independent experiments. $* P<0.05$ vs. CTL. 
put together in a new tube and submitted to a 90,000 $\mathrm{g}$ centrifugation at $4^{\circ} \mathrm{C}$ for $60 \mathrm{~min}$. The final pellet was resuspended as a total membrane fraction. The total protein concentration of membrane samples was assayed by the Bradford method and used for GLUT4
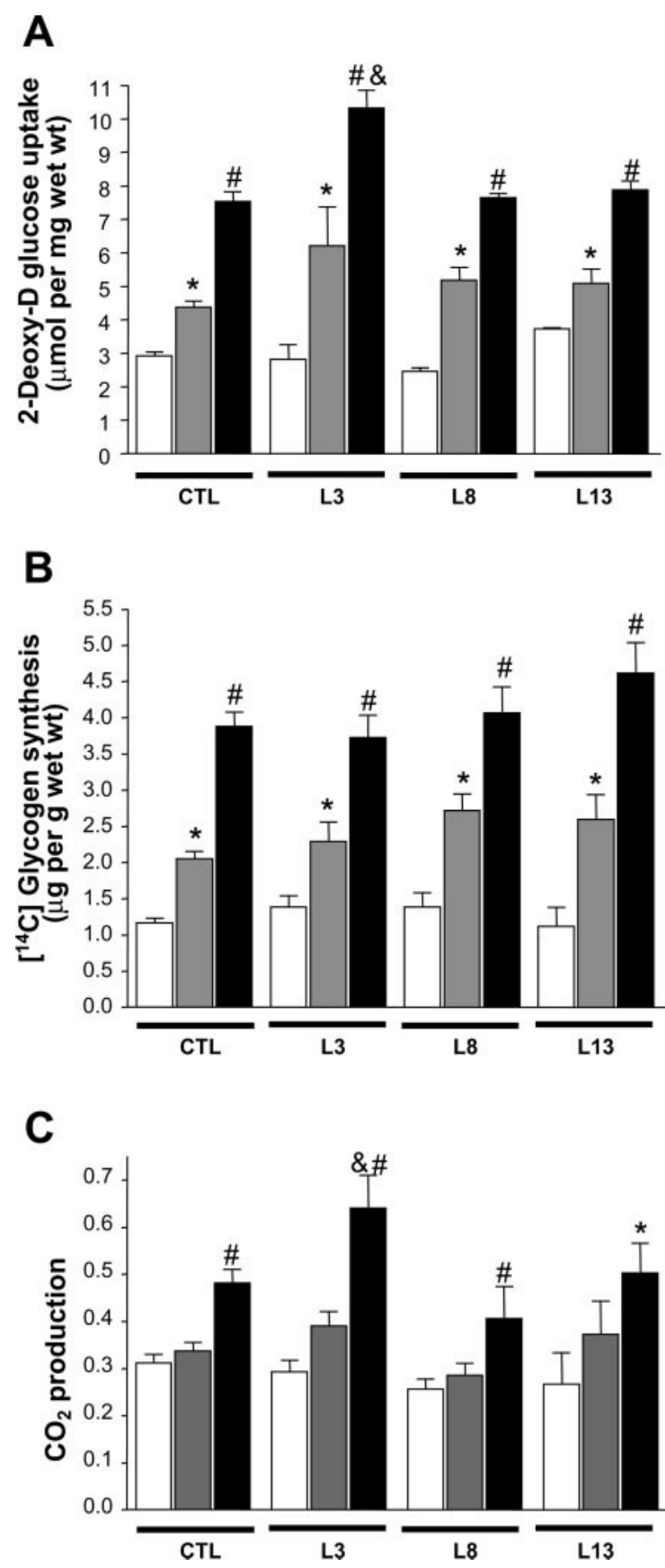

Fig. 2. Increased maximal insulin-induced glucose uptake and $\mathrm{CO}_{2}$ production in isolated soleus muscle from L3 rats. Virgin (CTL) and lactating rats at L3, L8, and L13 were killed by cervical dislocation and soleus muscles were rapidly and carefully isolated and processed for 2-deoxy-[D-2,6- $\left.{ }^{3} \mathrm{H}\right]$-glucose uptake $(A),\left[{ }^{14} \mathrm{C}\right]$-glycogen synthesis $(B)$, and ${ }^{14} \mathrm{CO}_{2}$ production $(C)$ as described in MATERIALS AND METHODS. Bars represent means \pm SE obtained from 3 independent experiments where the white bars are the muscles incubated in absence of insulin (basal), grey bars are the soleus incubated in insulin 0.1 $\mathrm{mU} / \mathrm{ml}$, and black bars are the soleus incubated in insulin $10 \mathrm{mU} / \mathrm{ml}$. $* P<$ 0.05 vs. basal within the same group; $\# P<0.05$ vs. insulin $0.1 \mathrm{mU} / \mathrm{ml}$ within the same group; $\& P<0.05$ vs. CTL incubated with insulin $10 \mathrm{mU} / \mathrm{ml}$.
A

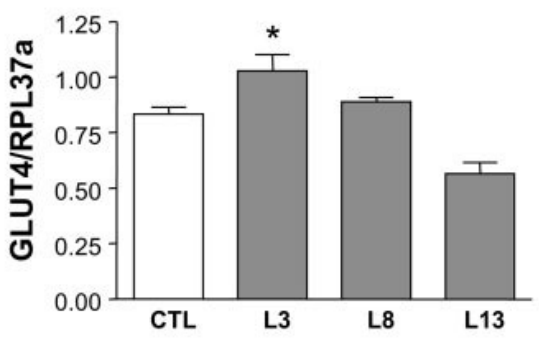

B
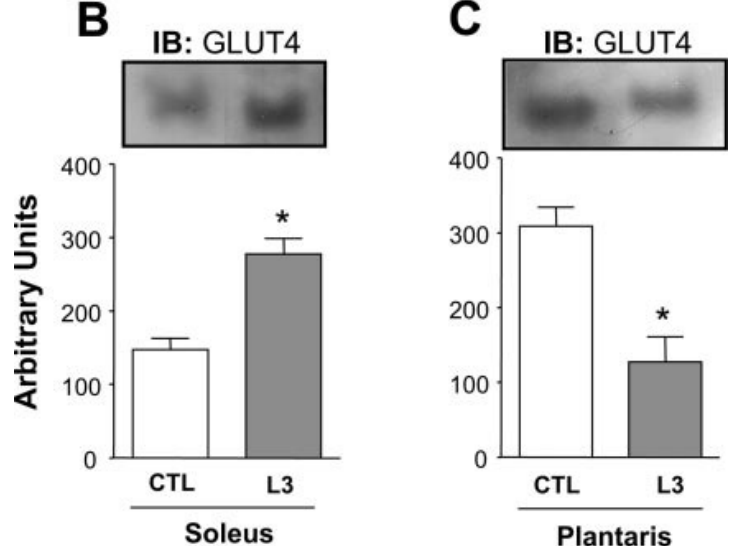

Fig. 3. Glucose transporter 4 (GLUT4) expression is increased in soleus and decreased in plantaris muscle from L3 rats. Virgin (CTL) and lactating rats at L3, L8, and L13 were killed by cervical dislocation, and soleus muscle were rapidly isolated and processed for RNA extraction and used for RT-PCR analysis of GLUT4 mRNA expression $(A)$. Soleus $(B)$ and plantaris $(C)$ muscle from CTL and L3 rats were also processed for total membrane protein extraction and Western blot analysis detection of GLUT4. The bars represent the relative expression of GLUT4 as determined by optical densitometry and are presented as means \pm SE. $* P<0.05$ vs. CTL.

protein analysis by Western blotting as described in Immunoprecipitation and immunoblotting.

$R N A$ extraction and RT-PCR analysis. Total RNA was extracted from $\sim 100 \mathrm{mg}$ of soleus muscle using Trizol reagent. Conventional RT-PCR analysis was performed as previously described (6). The amplification products were run on a $1.2 \%$ agarose gel containing ethidium bromide, and the band intensities were determined by digital scanning followed by quantification by using the Scion Image analysis software. The result was expressed as a ratio of the target gene to the housekeeping RPL37a. The primer sequences used for RT-PCR analysis with their respective melting point and lengths were as follows: GLUT4 sense, 5'-GCTGTGCCATCTTGATGACGG-3' and antisense, $5^{\prime}$-TGAAGAAGCCAAGCAGGAGGAC-3' $58.6^{\circ} \mathrm{C}, 300 \mathrm{bp}$; RPL37a sense, 5'-CAAGAAGGTCGGGATCGTCG-3' and antisense, 5'-ACCAGGCAAGTCTCAGGAGGTG-3' $3^{\prime}, 57^{\circ} \mathrm{C}, 289 \mathrm{bp}$.

Statistical analysis. All values were reported as means \pm SE. The results were analyzed by unpaired Student's $t$-test or one-way ANOVA, followed by Bonferroni post hoc testing when appropriate. $P$ values $<0.05$ indicated a significant difference.

\section{RESULTS}

Increased insulin sensitivity in lactating rats was observed 3 days after delivery and returned to control levels 7 days after the end of lactation. To characterize the beginning and the temporal extension of the increased insulin sensitivity, we performed intraperitoneal ITT in lactating rats starting at the 
3rd day of lactation. The glucose disappearance constant is increased at the 3 rd day of lactation $(\sim 2.4$-fold compared with control; $P<0.05$ ). This hypersensitivity remained at similar levels until the 21 st day $(\sim 1.8$-fold in L8, $\sim 2.6$-fold in L13, and $\sim 2$.2-fold in L21 compared with control; $P<0.05$ ). Seven days after the end of the lactation period (PL7), insulin sensitivity is similar to that observed in control rats (Fig. 1).

Increased maximal insulin-induced glucose uptake and $\mathrm{CO}_{2}$ production in isolated soleus muscle from early lactating rats. Insulin-induced glucose uptake (at $0.1 \mathrm{mU} / \mathrm{ml}$ ) was similar to control in L3, L8, and L13 (Fig. 2A). The same was observed for basal glucose uptake in isolated soleus muscle. However, the maximal insulin-induced glucose uptake was higher in early lactation (L3) than in control $(\sim 1.4$-fold; $P<0.05)$, and returned to values similar to control at L8 and L13.

The fate of glucose metabolism in soleus muscle was assessed by measurement of glycogen synthesis and $\mathrm{CO}_{2}$ production. Insulin-induced glycogen synthesis was increased to similar levels in control and lactating rats (Fig. 2B). Maximal insulin-induced $\mathrm{CO}_{2}$ production reached higher values in soleus muscles isolated from rats in early lactation (L3) than in control ( $\sim 1.44$-fold; $P<0.05$, Fig. $2 C$ ). This temporal pattern of insulin-induced $\mathrm{CO}_{2}$ production in soleus from lactating rats is similar to that observed for insulin-induced glucose uptake.

GLUT4 expression is increased in soleus and decreased in plantaris muscle from L3 rats. To investigate the mechanism involved in the increased glucose uptake in early lactation we first determined the expression of GLUT4. The relative quantity of GLUT4 mRNA was increased in soleus 3 days after delivery $(\sim 1.23$-fold; $P<0.05)$ and returned to control levels 8 days postpartum (Fig. 3A). GLUT4 protein content at L3 was increased $(\sim 1.85$-fold; $P<0.05)$ in soleus muscle (Fig. $3 B)$ and decreased $(\sim 0.40$-fold; $P<0.05)$ in plantaris muscle (Fig. $3 C$ ).

Increased IR expression and insulin-induced tyrosine phosphorylation in soleus muscle from early lactating rats (L3). The band migrating at $95 \mathrm{kDa}$ corresponds to the $\beta$-subunit of the IR in a protein extract resolved in SDS-PAGE (25). The ability of insulin to induce IR- $\beta$ subunit tyrosine phosphorylation was significantly higher in soleus muscle from L3 than in control rats $(1.58$-fold; $P<0.05$, Fig. $4 A)$. In contrast, IR tyrosine phosphorylation in plantaris muscle at L3 was similar to that of control rats (Fig. 4B). Not only the insulin-induced tyrosine phosphorylation but also the IR expression was increased 3 days after delivery $(1.70$-fold; $P<0.05)$ and re-
Fig. 4. Increased insulin receptor (IR) expression and insulin-induced tyrosine phosphorylation in soleus muscle from L3 rats. Virgin (CTL) and lactating rats at L3, L8, and L13 were anesthetized and the soleus muscle was removed (basal $=-$, white bars). Plantaris muscle was removed from CTL and L3 rats. The abdominal cavity was opened, and the portal vein was injected with $0.5 \mathrm{ml}$ of a $10^{-5} \mathrm{M}$ insulin solution. After $90 \mathrm{~s}$, the remaining soleus muscle was removed (black bars). The remaining plantaris was removed from CTL and L3-stimulated rats. Stimulated and unstimulated muscles were processed for protein extraction, resolved in $6.5 \%$ SDSPAGE, and the membranes with soleus $(A)$ and plantaris $(B)$ samples were used for immunoblotting (IB) with anti-pTyr antibody. Separated gels containing exclusively the basal samples from soleus $(C)$ - and plantaris $(D)$-originated membranes that were probed with anti-IR antibody. The bars represent the IR tyrosine phosphorylation and protein content determined by optical densitometry and are presented as means \pm SE. $* P<0.05$ vs. basal within the same group; $\& P<0.05$ vs. stimulated CTL; \#P<0.05 vs. CTL.
A

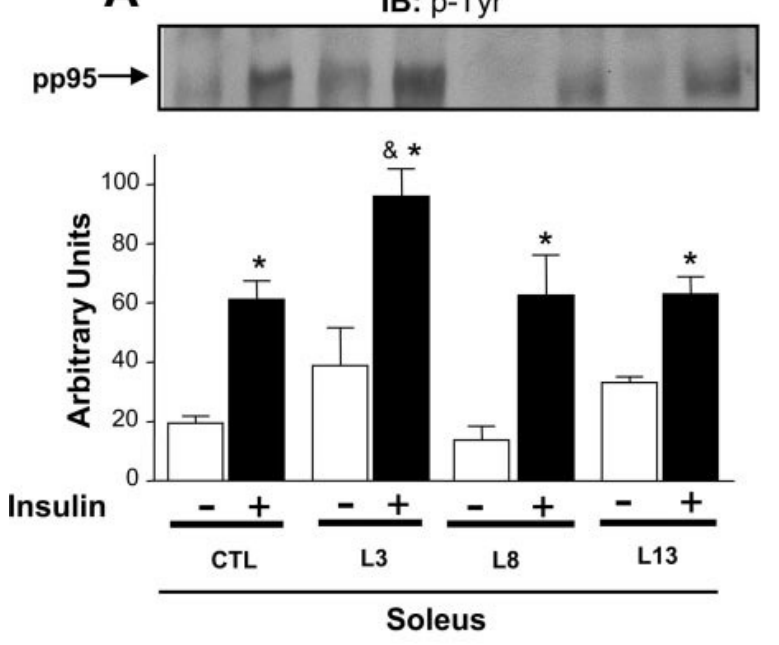

C
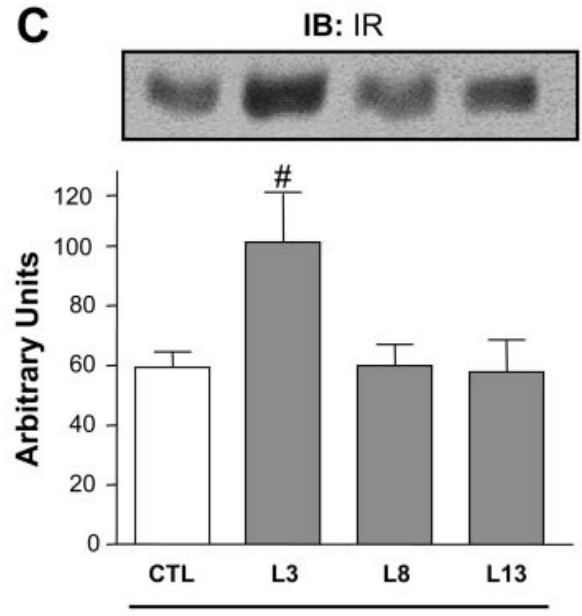

Soleus

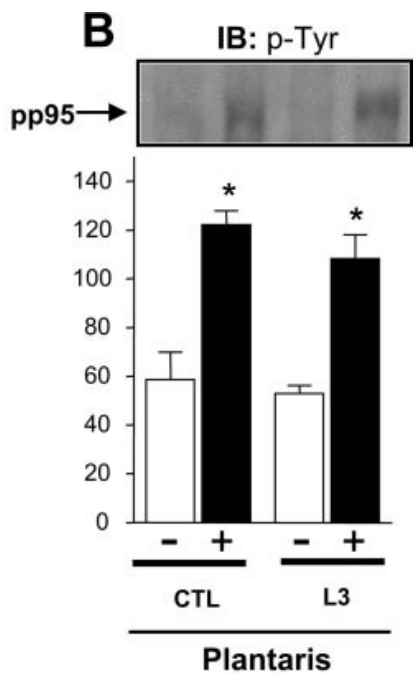

D

IB: IR
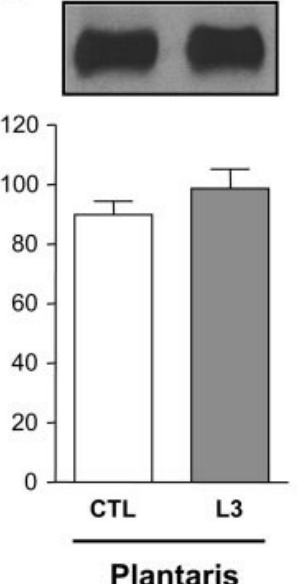
turned to control levels 8 and 13 days postpartum (Fig. 4C). IR expression is not altered in plantaris muscle at L3 (Fig. 4D).

Unchanged IRS1 and IRS2 expression and insulin-induced ppl85 tyrosine phosphorylation in soleus muscle from lactating rats. Upon activation, the insulin receptor catalyzes the tyrosine phosphorylation of several intracellular substrates, including the IRS1 and IRS2. IRS1 and IRS2 migrate at the region of the 165-185 $\mathrm{kDa}$ proteins (pp185). Insulin induced a similar increase in pp185 tyrosine phosphorylation in both soleus and plantaris muscle from control and lactating rats $(P<0.05$ vs. basal, Figs. 5, $A$ and B). Additionally, IRS1 and IRS2 protein levels are not altered during lactation in soleus muscle ( Figs. 5, $C$ and $E$. respectively) and plantaris muscle (Figs. 5, $D$ and $F$, respectively).

Increased IRS2 but not IRS1 tyrosine phosphorylation and association with PI3-kinase in soleus muscle from early lactating rats (L3). Because the main IR targets for tyrosine phosphorylation are IRS1 and IRS2 and we did not find any

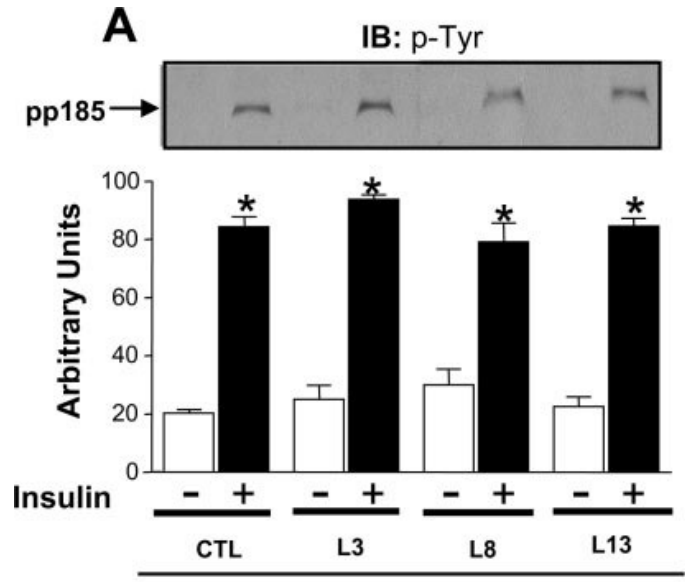

Soleus

C

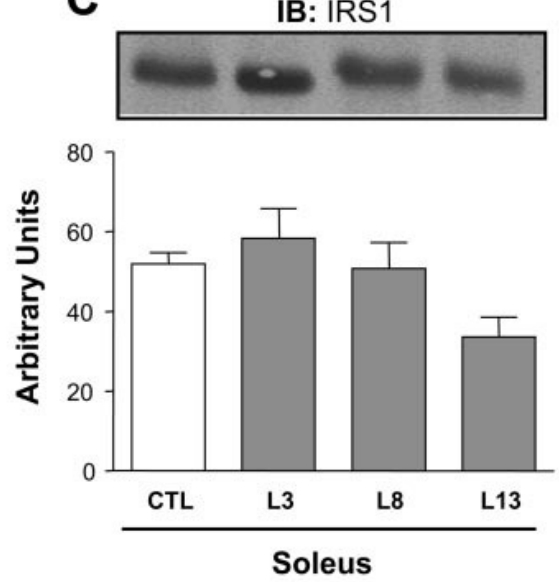

E
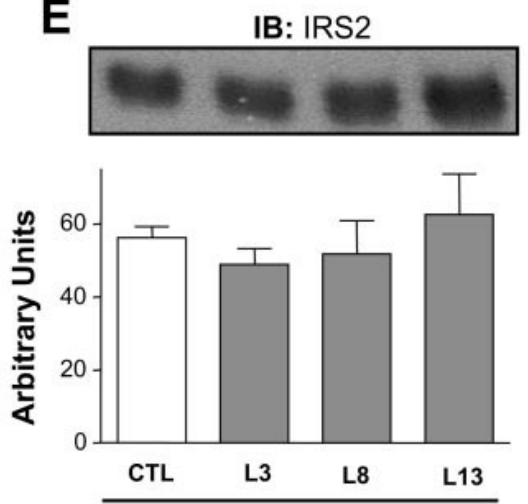

Soleus

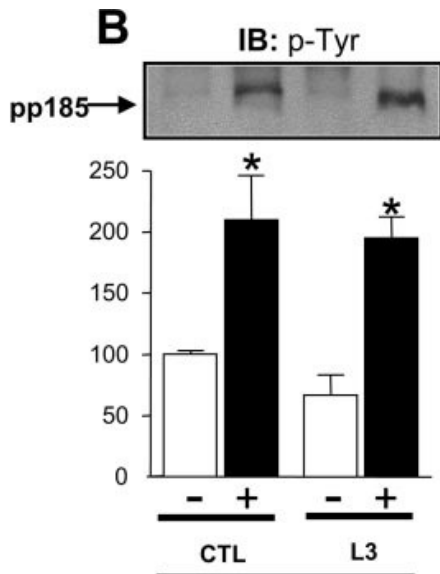

Plantaris

D
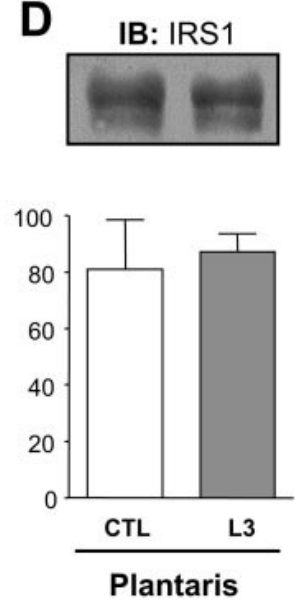

F IB: IRS2

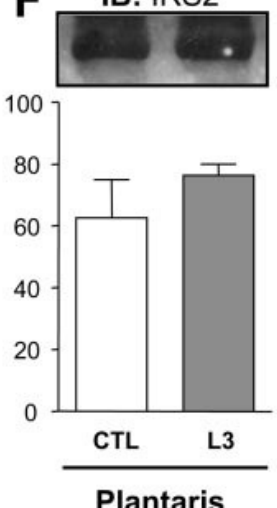

Fig. 5. Unchanged IR substrate (IRS) 1 and IRS2 expression and insulin-induced pp185 tyrosine phosphorylation in soleus from L3 rats. Virgin (CTL) and lactating rats at L3, L8, and L13 were anesthetized, and the soleus muscle was removed (basal $=-$, white bars). Plantaris muscle was removed from CTL and L3 rats. The abdominal cavity was opened, and the portal vein was injected with $0.5 \mathrm{ml}$ of a $10^{-5} \mathrm{M}$ insulin solution. After $90 \mathrm{~s}$, the remaining soleus muscle was removed (black bars). The remaining plantaris was removed from CTL and L3-stimulated rats. Stimulated and unstimulated muscles were processed for protein extraction, resolved in $6.5 \%$ SDS-PAGE, and the membranes with soleus $(A)$ and plantaris $(B)$ samples were probed with antipTyr antibody. Separated gels containing exclusively the basal soleus and plantaris samples originated membranes that were probed with antiIRS1 ( $C$ and $D$, respectively) and anti-IRS2 ( $E$ and $F$, respectively) antibodies. The bars represent the pp185 tyrosine phosphorylation and IRS1 and IRS2 protein content determined by optical densitometry and are presented as means \pm SE. $* P<0.05$ vs. basal within the same group. 
A

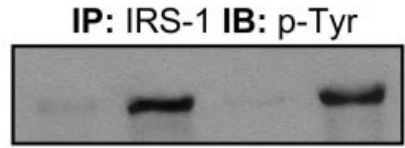

Fig. 6. Increased IRS2 but not IRS1 tyrosine phosphorylation and association with PI3-kinase (PI3K) in soleus muscle from $\mathrm{L} 3$ rats. Virgin (CTL) and lactating rats at L3 were anesthetized and the soleus muscle was removed (basal $=-$, white bars). The abdominal cavity was opened and the portal vein was injected with $0.5 \mathrm{ml}$ of a $10^{-5} \mathrm{M}$ insulin solution After $90 \mathrm{~s}$, the remaining soleus muscle was removed (black bars). Stimulated and unstimulated muscles were processed for immunoprecipitation (IP) with anti-IRS1 and anti-IRS2 antibodies. The precipitated proteins were resolved in 6.5\% SDS-PAGE and transferred to different nitrocellulose membranes. Both IRS1- and IRS2-containing membranes were probed with anti-pTyr ( $A$ and $B$, respectively) and anti-PI3kinase ( $C$ and $D$, respectively). The bars represent the IRS1 and IRS2 tyrosine phosphorylation and association with PI3-kinase determined by optical densitometry and are presented as means $\pm \mathrm{SE}$. $* P<0.05$ vs. basal within the same group; $\& P<0.05$ vs. stimulated CTL.

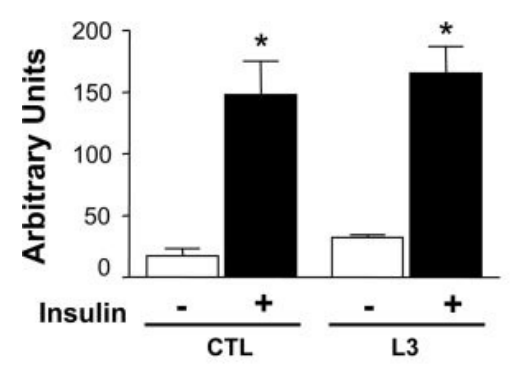

C

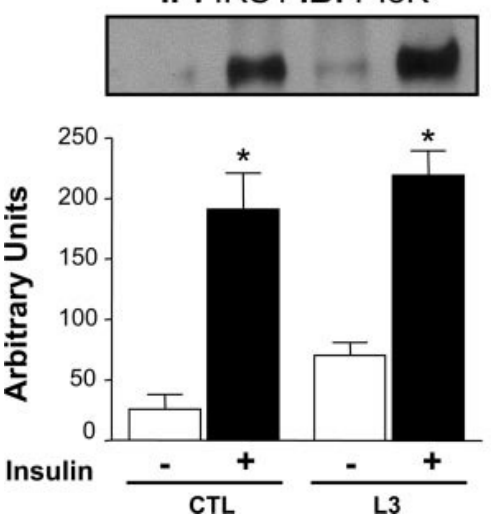

B IP: IRS-2 IB: p-Tyr
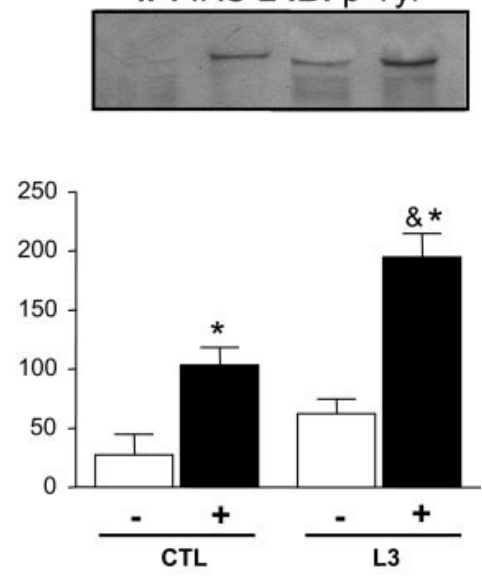

D

IP: IRS2 IB: PI3K
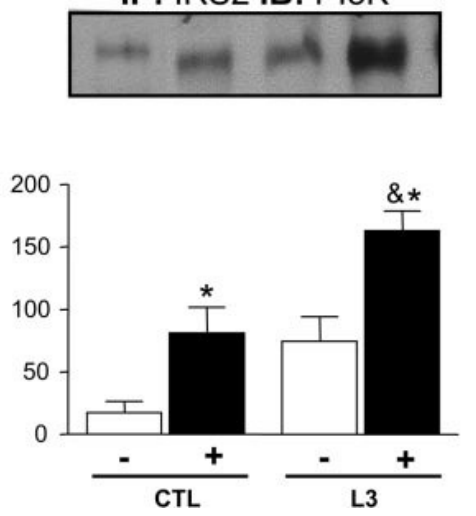

change in pp185 tyrosine phosphorylation and IRS1 and IRS2 content in L3, we then used the immunoprecipitation approach to investigate whether the changes were specific for IRS 1 or IRS2 phosphorylation. The present results show that insulininduced IRS1 tyrosine phosphorylation is similar in control and L3 rats (Fig. 6A). However, insulin-induced IRS2 tyrosine phosphorylation is significantly higher in L3 compared with control rats (1.88-fold; $P<0.05$; Fig. $6 B$ ). As demonstrated herein, the same pattern of results was obtained for the association of these substrates with the regulatory subunit of PI3-kinase. Insulin-induced IRS1/PI3-kinase association is similar for control and L3 rats (Fig. 6C) but stimulated formation of the IRS2/PI3-kinase complex was increased in L3 rats (2.00-fold; $P<0.05$; Fig. $6 D$ ).

Increased insulin-induced AKT serine phosphorylation in soleus muscle from early lactating rats (L3). Although PI3kinase activity is clearly necessary for insulin-stimulated glucose uptake, additional downstream signals are also required for the stimulation of GLUT4 translocation. One of the PI3kinase targets is the serine/threonine kinase known as PKB or AKT (36). Insulin induced serine phosphorylation of AKT in control and lactating rats $(P<0.05$ vs. basal levels, Fig. 7). However, insulin-induced AKT serine phosphorylation reached higher values in L3 (1.49-fold vs. control; $P<0.05)$ and returned to levels similar to that of control in L8 and L13.
Decreased PTP1B expression in soleus muscle from early lactating rats (L3). Two PTPases have been implicated in the negative regulation of the insulin signaling, namely PTP1B and LAR (36). We have found a decrease in PTP1B expression in early lactating rats (L3), as showed in Fig. $8 A$ (0.17-fold vs. control; $P<0.05)$. Additionally, PTP1B levels returned to the levels observed in control at L8 and L13 (Fig. 8). In contrast to soleus, plantaris muscle did not exhibit any change in PTP1B expression at L3 (Fig. 8B). We have also assessed the mRNA levels of LAR but it was not altered during lactation (data not shown).

\section{DISCUSSION}

Stuebe et al. (40) recently demonstrated that the longer duration of breast feeding was associated with the reduced incidence of type 2 diabetes in women. Lactation may reduce risk of type 2 diabetes in young and middle-aged women by improving glucose homeostasis that was independent of the body weight. Considering that the latest projection from the International Diabetes Federation suggests that 190 million people worldwide currently have type 2 diabetes, a clear understanding of the mechanisms underlying the glucose homeostasis during lactation might help to develop new strategies to prevent what is considered, in terms of glucose intolerance, the largest epidemia in human history. 
IB: pAKT-Ser
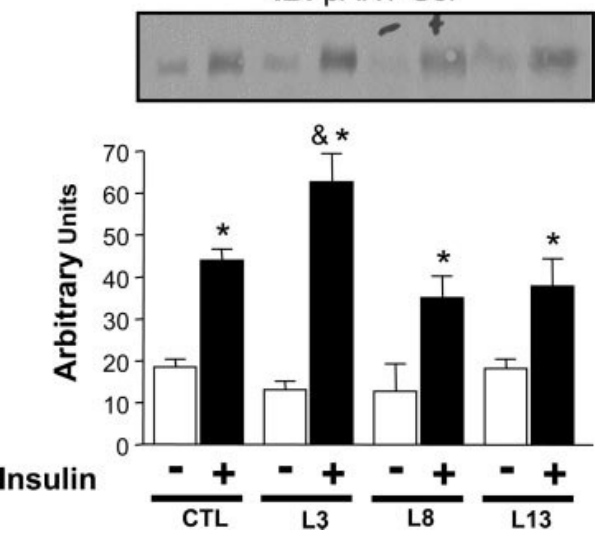

Fig. 7. Increased insulin-induced AKT serine phosphorylation (pAKT-Ser) in soleus muscle from L3 rats. Virgin (CTL) and lactating rats at L3, L8, and L13 were anesthetized, and the soleus muscle was removed (basal $=-$, white bars). The abdominal cavity was opened, and the portal vein was injected with $0.5 \mathrm{ml}$ of a $10^{-5} \mathrm{M}$ insulin solution. After $90 \mathrm{~s}$, the remaining soleus muscle was removed (black bars). Stimulated and unstimulated muscles were processed for protein extraction, resolved in 6.5\% SDS-PAGE, and the membranes were probed with anti-pAKT antibody. The bars represent the serine AKT phosphorylation determined by optical densitometry and are presented as means $\pm \mathrm{SE}$. $* P<0.05$ vs. basal within the same group; $\& P<0.05$ vs stimulated CTL.

In 1986, Burnol et al. (9) demonstrated that the lactation period is characterized by increased insulin sensitivity. This data was achieved by the use of hyperinsulinemic euglycemic clamp applied to lactating rats at 11-13 day postpartum. A former study from this group, however, collected important data suggesting that improved response to insulin could take place in early lactation (3 days postpartum) (8). Therefore, we first focused on the search for temporal limits of the increased insulin sensitivity. By using an insulin tolerance test, we determined that lactation is an entirely insulin-hypersensitive period. Thus, insulin resistance observed in late pregnant rats is rapidly switched to hypersensitivity at L3. This feature is no longer observed $1 \mathrm{wk}$ after the end of lactation.

Skeletal muscles represent the most important tissues responsible for glucose clearance after an intravenous glucose or insulin administration. Skeletal muscles that are predominantly composed by glycolytic fibers like epitrochlearis and extensor digitorum longus display reduced insulin-dependent glucose uptake during late pregnancy $(31,38)$, and, in the case of the epitrochlearis, insulin resistance is also detectable at 11-13 day postpartum (11). Similarly, the adipose tissue, another major territory for glucose disposal, is also insulin resistant in late pregnant and midlactating rats $(11,18,31)$. In contrast, the soleus skeletal muscle, which is predominantly composed by oxidative fibers, does not present resistance to insulin action during late pregnancy (30). Therefore, soleus muscle was chosen as a candidate to participate in the increased insulin sensitivity in early lactation and therefore contributes to glycemic control in the postpartum period. In fact, our results showed that maximal insulin-induced glucose uptake and $\mathrm{CO}_{2}$ production in isolated soleus is increased in early lactating rats.

Although glycolytic fibers account for $\sim 75 \%$ of hindlimb skeletal muscle mass, the blood flow through predominantly oxidative muscles is 3 to 4 times higher than that of predominantly glycolytic muscles (3). Therefore, the relative small increase in the insulin-induced glucose uptake obtained in 1-h-stimulated soleus muscles from L3 rats may become markedly significant in a chronic situation. As a consequence, the phenomenon observed in oxidative muscles might account for an important part in the twofold increase in whole body insulin sensitivity during early lactation, as observed in vivo during the ITT test.

This feature of the oxidative skeletal muscle is noticed in a critical moment when the conceptus is no longer present and, therefore, a considerable amount of glucose from the bloodstream must be driven to an alternative territory. Thus, our results led us to postulate that the increased responsiveness to insulin of oxidative muscles (e.g., soleus muscle) might contribute to normal glucose homeostasis of the maternal organism in the postpartum. This phenomenon is temporally restricted to the early lactation, and, as the lactation proceeds, other tissues, such as the mammary gland, will certainly assume its role in the hypersensitivity to insulin and glucose disposal. Indeed, at 11-13 days of lactation on, the fraction of glucose taken up by the mammary gland to ensure milk synthesis represents a large percentage of the total glucose turnover rate in fed rats (42).

Oxidative soleus muscle, rather than the glycolytic epitrochlearis muscle, is notably more susceptible to the effect of insulin sensitizing agents in pathological situations of insulin resistance. This was demonstrated by upregulation of glucose uptake and postreceptor signaling steps selectively in soleus muscle from obese Zucker rats $(14,22)$. In accordance with these observations, the present study describes a physiological situation where the transition from an overall insulin resistance (pregnancy) to hypersensitivity condition (lactation) is marked by an increased insulin response of the oxidative soleus muscle. The reason for this specific response of oxidative muscles may be explained by the high expression and activity of the insulin signaling proteins (39) and GLUT4 (21) compared with the glycolytic fibers. In accordance with these studies, we found that GLUT4 protein content and mRNA levels are increased in the oxidative soleus muscle but, in the case of GLUT4 protein, are decreased in the glycolytic plantaris muscle.
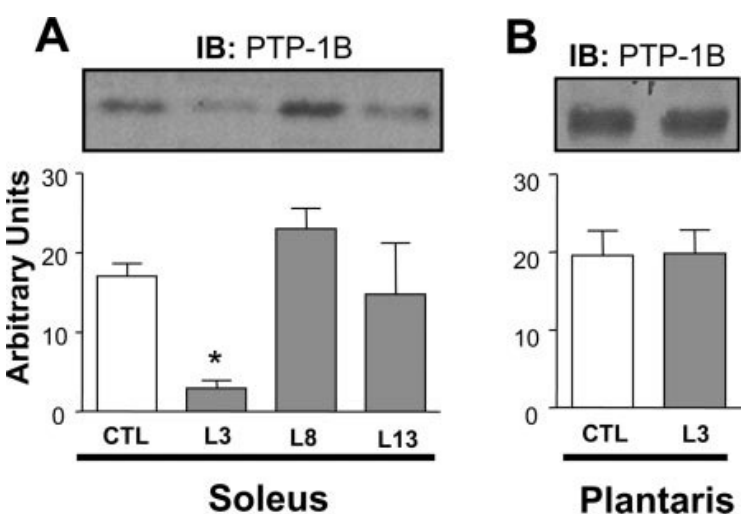

Fig. 8. Decreased protein tyrosine phosphatases 1B (PTP1B) expression in soleus muscle from L3 rats. Virgin (CTL) and lactating rats at L3, L8, and L13 were killed by cervical dislocation, and soleus muscles were rapidly isolated and processed for protein extraction. Plantaris muscle was removed from CTL and L3 rats. The samples were resolved in $8 \%$ SDS-PAGE and the membranes containing soleus $(A)$ and plantaris $(B)$ samples were probed with anti-PTP1B antibody. The bars represent the PTP1B protein content determined by optical densitometry and are presented as means \pm SE. $* P<0.05$ vs. CTL. 
Some of the molecular alterations in soleus muscle that we described herein are observed in skeletal muscle from other experimental situations that display increased insulin sensitivity. For instance, caloric restriction promotes an increase in IR activity (44), and exercise training upregulates GLUT4 expression (29) and insulin-induced AKT phosphorylation (33). It is important to note that, like GLUT4 expression, other key proteins of the insulin signaling pathway are upregulated in soleus muscle exclusively during early lactation (e.g., IR expression and tyrosine phosphorylation). Corroborating the idea that participation in increased insulin sensitivity during early lactation is restricted to oxidative muscles, no changes regarding expression of IR, GLUT4, IRS1, IRS2, and phosphorylation of AKT were detected in gastrocnemius muscles from early lactating rats (data not shown). Taken together, these results suggest that increased responsiveness to insulin at the postpartum is attributed exclusively to muscles that are predominantly composed by oxidative fibers.

A remarkable observation of the present study was that the improved insulin action in soleus muscle at L3 lies in the fact that IRS2, but not IRS1, displayed higher insulin-induced tyrosine phosphorylation and association with the regulatory subunit of PI3-kinase. This seems to be a unique feature of early lactation since the majority of the published studies in this field suggest that IRS1, rather than IRS2, is the major substrate leading to stimulation of glucose transport in skeletal muscle (41). The latest studies concerning this issue have demonstrated, by the use of interference RNA, that IRS1 knockdown impairs insulin-induced glucose uptake in skeletal muscle cell lineages, which is not observed for IRS2 knockdown $(7,27)$.

The results presented herein, however, are in accordance with other reports that have pointed out for the participation of IRS2 in skeletal muscle insulin response. In humans and rodents, specific upregulation of insulin-induced IRS2 association with PI3-kinase accounts, at least in part, for the sensitizing effect of a single bout of exercise $(25,26)$. Furthermore, a classic study of Withers et al. (43) demonstrated that IRS2deficient mice show progressive deterioration of glucose homeostasis due to insulin resistance in the liver and skeletal muscle and a lack of $\beta$-cell compensation for this insulin resistance.

Together with the positive regulation of the IRS2/PI3kinase/AKT pathway, we have found a reduction in PTP1B protein content in soleus muscle from L3 rats. This result is in accordance with previous studies that show elevated expression of this phosphatase in conditions of insulin resistance (1, 20), and its abrogation in conditions of enhanced insulin sensitivity (15). Again, PTP1B reduction is temporally limited to the early stage of lactation and is not observed in plantaris muscle.

Insulin resistance during pregnancy is attributed to a complex change in plasma hormonal levels. In humans, there is strong evidence that high values of placental growth hormone $(\mathrm{GH})$ exert a major role in insulin resistance during late gestation (19). In rats, a marked increase in circulating levels of GH during late pregnancy has already been observed $(13,16)$; however, the pituitary and/or placental origin of this hormone has not been clearly established. In addition to $\mathrm{GH}$, other hormones have been suggested as participating in the genesis of insulin resistance in pregnant rats. Progesterone has the prominent ability to decrease insulin-stimulated glucose metabolism in isolated rat muscles (32). On the other hand, the participation of placental lactogens is controversial. Leturque and colleagues have demonstrated that placental lactogens do not interfere in insulin-induced glucose utilization by isolated muscle (32), but a former study from Ryan and Enns (37) suggested that placental lactogens and prolactin impair insulin action in adipose cells by affecting postreceptor binding events. Additionally, it is unlikely that placental lactogens and prolactin participate in the skeletal muscle insulin resistance from pregnant rats, because this tissue contains a reduced number of mRNA copies that encode for the long functional form of the prolactin receptor (34). Finally, the plasma levels of prolactin remain elevated on the 3rd day after the delivery (28) when an increased soleus muscle response to insulin is observed.

It was not the purpose of the present study to determine which factors during the transition from pregnancy to lactation generate the phenomenon described herein; however, we can speculate on potential candidates. After the delivery, it is notable that rats exhibit a rapid fall in progesterone and $\mathrm{GH}$ circulating levels, reaching the control levels in 3 days $(16,28)$, which might play an important role for the increased insulin response of the soleus muscle in early lactation.

In summary, we demonstrated herein that the increased insulin response in soleus muscle at 3rd day postpartum participates in the overall insulin sensitivity to the hormone observed in early lactation. This phenomenon is an exclusive feature of oxidative skeletal muscles and is associated with increased phosphorylation of IR, IRS2, AKT, and PI3-kinase association with IRS2, GLUT4, and IR expression, and decreased content of PTP1B. These results point to a new mechanism by which early lactating rats might maintain glycemic homeostasis postpartum, a critical moment when the conceptus, the most important territory responsible for the maternal glucose disposal, is no longer present.

\section{ACKNOWLEDGMENTS}

The authors thank M. A. S. Lima for technical assistance and M. T. Nunes for helpful discussion.

\section{GRANTS}

This work was supported by the Brazilian foundations Fundaçáo de Amparo à Pesquisa do Estado de São Paulo, Coordenaçáo de Aperfeiçoamento de Pessoal de Nivel Superior, and Conselho Nacional de Desenvoluimento Científico e Tecnológico.

\section{REFERENCES}

1. Ahmad F, Goldstein BJ. Alterations in specific protein-tyrosine phosphatases accompany insulin resistance of streptozotocin diabetes. Am J Physiol Endocrinol Metab 268: E932-E940, 1995.

2. Anhê GF, Caperuto LC, Pereira-Da-Silva M, Souza LC, Hirata AE, Velloso LA, Cipolla-Neto J, Carvalho CR. In vivo activation of insulin receptor tyrosine kinase by melatonin in the rat hypothalamus. J Neurochem 90: 559-566, 2004.

3. Armstrong RB, Phelps RO. Muscle fiber type composition of the rat hindlimb. Am J Anat 171: 259-272, 1984.

4. Barros RP, Machado UF, Gustafsson JA. Estrogen receptors: new players in diabetes mellitus. Trends Mol Med 12: 425-431, 2006.

5. Bonora E, Manicardi V, Zavaroni I, Coscelli C, Butturini U. Relationships between insulin secretion, insulin metabolism and insulin resistance in mild glucose intolerance. Diabetes Metab 13: 116-121, 1987.

6. Bordin S, Amaral ME, Anhê GF, Delghingaro-Augusto V, Cunha DA, Nicoletti-Carvalho JE, Boschero AC. Prolactin-modulated gene expres- 
sion profiles in pancreatic islets from adult female rats. Mol Cell Endocrinol 220: 41-50, 2004.

7. Bouzakri K, Zachrisson A, Al-Khalili L, Zhang BB, Koistinen HA, Krook A, Zierath JR. siRNA-based gene silencing reveals specialized roles of IRS-1/Akt2 and IRS-2/Akt1 in glucose and lipid metabolism in human skeletal muscle. Cell Metab 4: 89-96, 2006.

8. Burnol AF, Leturque A, Ferre P, Girard J. Glucose metabolism during lactation in the rat: quantitative and regulatory aspects. Am J Physiol Endocrinol Metab 245: E351-E358, 1983.

9. Burnol AF, Leturque A, Ferre P, Kande J, Girard J. Increased insulin sensitivity and responsiveness during lactation in rats. Am J Physiol Endocrinol Metab 251: E537-E541, 1986.

10. Burnol AF, Guerre-Millo M, Lavau M, Girard J. Effect of lactation on insulin sensitivity of glucose metabolism in rat adipocytes. FEBS Lett 194: 292-296, 1986.

11. Burnol AF, Ferre P, Leturque A, Girard J. Effect of insulin on in vivo glucose utilization in individual tissues of anesthetized lactating rats. Am J Physiol Endocrinol Metab 252: E183-E188, 1987.

12. Burnol AF, Ebner S, Kande J, Girard J. Insulin resistance of glucose metabolism in isolated brown adipocytes of lactating rats. Evidence for a post-receptor defect in insulin action. Biochem J 265: 511-517, 1990.

13. Carlsson L, Eden S, Jansson JO. The plasma pattern of growth hormone in conscious rats during late pregnancy. J Endocrinol 124: 191-198, 1990.

14. Dokken BB, Sloniger JA, Henriksen EJ. Acute selective glycogen synthase kinase-3 inhibition enhances insulin signaling in prediabetic insulin-resistant rat skeletal muscle. Am J Physiol Endocrinol Metab 288: E1188-E1194, 2005

15. Elchebly M, Payette P, Michaliszyn E, Cromlish W, Collins S, Loy AL, Normandin D, Cheng A, Himms-Hagen J, Chan CC, Ramachandran C, Gresser MJ, Tremblay ML, Kennedy BP. Increased insulin sensitivity and obesity resistance in mice lacking the protein tyrosine phosphatase-1B gene. Science 283: 1544-1548, 1999.

16. Escalada J, Sanchez-Franco F, Velasco B, Cacicedo L. Regulation of growth hormone $(\mathrm{GH})$ gene expression and secretion during pregnancy and lactation in the rat: role of insulin-like growth factor-I, somatostatin, and GH-releasing hormone. Endocrinology 138: 3435-3443, 1997.

17. Espinal J, Beggs M, Randle PJ. Assay of branched-chain $\alpha$-keto acid dehydrogenase kinase in mitochondrial extracts and purified branchedchain $\alpha$-keto acid dehydrogenase complexes. Methods Enzymol 166: $166-175,1988$

18. Ferre P, Burnol AF, Leturque A, Terretaz J, Penicaud L, Jeanrenaud B, Girard J. Glucose utilization in vivo and insulin-sensitivity of rat brown adipose tissue in various physiological and pathological conditions. Biochem J 233: 249-252, 1986.

19. Freemark M. Regulation of maternal metabolism by pituitary and placental hormones: roles in fetal development and metabolic programming. Horm Res 65, Suppl 3: 41-49, 2006.

20. Goldstein BJ, Ahmad F, Ding W, Li PM, Zhang WR. Regulation of the insulin signalling pathway by cellular protein-tyrosine phosphatases. Mol Cell Biochem 182: 91-99, 1998.

21. Henriksen EJ, Bourey RE, Rodnick KJ, Koranyi L, Permutt MA, Holloszy JO. Glucose transporter protein content and glucose transport capacity in rat skeletal muscles. Am J Physiol Endocrinol Metab 259: E593-E598, 1990.

22. Henriksen EJ, Kinnick TR, Teachey MK, O'Keefe MP, Ring D, Johnson KW, Harrison SD. Modulation of muscle insulin resistance by selective inhibition of GSK-3 in Zucker diabetic fatty rats. Am J Physiol Endocrinol Metab 284: E892-E900, 2003.

23. Hirabara SM, Carvalho CRO, Mendonca JR, Haber EP, Fernandes LC, Curi R. Palmitate acutely raises glycogen synthesis in rat soleus muscle by a mechanism that requires its metabolization (Randle cycle). FEBS Lett 541: 109-114, 2003.

24. Hirabara SM, Silveira LR, Alberici LC, Leandro CV, Lambertucci RH, Polimeno GC, Cury Boaventura MF, Procopio J, Vercesi AE,
Curi R. Acute effect of fatty acids on metabolism and mitochondrial coupling in skeletal muscle. Biochim Biophys Acta 1757: 57-66, 2006.

25. Howlett KF, Sakamoto K, Hirshman MF, Aschenbach WG, Dow M, White MF, Goodyear LJ. Insulin signaling after exercise in insulin receptor substrate-2-deficient mice. Diabetes 51: 479-483, 2002.

26. Howlett KF, Sakamoto K, Yu H, Goodyear LJ, Hargreaves M. Insulin-stimulated insulin receptor substrate-2-associated phosphatidylinositol 3-kinase activity is enhanced in human skeletal muscle after exercise. Metabolism 55: 1046-1052, 2006

27. Huang C, Thirone AC, Huang X, Klip A. Differential contribution of insulin receptor substrates 1 vs. 2 to insulin signaling and glucose uptake in 16 myotubes. J Biol Chem 280: 19426-19435, 2005

28. Kawai M, Kishi K. Adaptation of pancreatic islet B-cells during the last third of pregnancy: regulation of B-cell function and proliferation by lactogenic hormones in rats. Eur J Endocrinol 141: 419-425, 1999.

29. Kim HJ, Lee JS, Kim CK. Effect of exercise training on muscle glucose transporter 4 protein and intramuscular lipid content in elderly men with impaired glucose tolerance. Eur J Appl Physiol 93: 353-358, 2004.

30. Leturque A, Satabin P, Ferre P, Girard JR. Evidence that stimulation of glucose metabolism by insulin is not altered in isolated soleus muscle of pregnant rats. Biochem J 200: 181-184, 1981.

31. Leturque A, Ferre P, Burnol AF, Kande J, Maulard P, Girard J. Glucose utilization rates and insulin sensitivity in vivo in tissues of virgin and pregnant rats. Diabetes 35: 172-177, 1986.

32. Leturque A, Hauguel S, Sutter Dub MT, Maulard P, Girard J. Effects of placental lactogen and progesterone on insulin stimulated glucose metabolism in rat muscles in vitro. Diabetes Metab 15: 176-181, 1989.

33. Luciano E, Carneiro EM, Carvalho CR, Carvalheira JB, Peres SB, Reis MA, Saad MJ, Boschero AC, Velloso LA. Endurance training improves responsiveness to insulin and modulates insulin signal transduction through the phosphatidylinositol 3-kinase/Akt-1 pathway. Eur J Endocrinol 147: 149-157, 2002

34. Nagano M, Kelly PA. Tissue distribution and regulation of rat prolactin receptor gene expression. Quantitative analysis by polymerase chain reaction. J Biol Chem 269: 13337-13345, 1994.

35. Okamoto MM, Sumida DH, Carvalho CR, Vargas AM, Heimann JC, Schaan BD, Machado UF. Changes in dietary sodium consumption modulate GLUT4 gene expression and early steps of insulin signaling. Am J Physiol Regul Integr Comp Physiol 286: R779-R785, 2004.

36. Pessin JE, Saltiel AR. Signaling pathways in insulin action: molecular targets of insulin resistance. J Clin Invest 106: 165-169, 2000.

37. Ryan EA, Enns L. Role of gestational hormones in the induction of insulin resistance. J Clin Endocrinol Metab 67: 341-347, 1988.

38. Sancho R, Kim J, Cartee GD. Decreased contraction-stimulated glucose transport in isolated epitrochlearis muscles of pregnant rats. J Appl Physiol 98: 1021-1027, 2005.

39. Song XM, Ryder JW, Kawano Y, Chibalin AV, Krook A, Zierath JR. Muscle fiber type specificity in insulin signal transduction. Am J Physiol Regul Integr Comp Physiol 277: R1690-R1696, 1999.

40. Stuebe AM, Rich-Edwards JW, Willett WC, Manson JE, Michels KB. Duration of Lactation and incidence of type 2 diabetes. JAMA 294: 2601-2610, 2005

41. Thirone AC, Huang C, Klip A. Tissue-specific roles of IRS proteins in insulin signaling and glucose transport. Trends Endocrinol Metab 17: 72-78, 2006.

42. Williamson DH. Integration of metabolism in tissues of the lactating rat FEBS Lett 117: K93-K105, 1980.

43. Withers DJ, Gutierrez JS, Towery H, Burks DJ, Ren JM, Previs S, Zhang Y, Bernal D, Pons S, Shulman GI, Bonner-Weir S, White MF. Disruption of IRS-2 causes type 2 diabetes in mice. Nature 391: 900-904, 1998.

44. Zhu M, de Cabo R, Lane MA, Ingram DK. Caloric restriction modulates early events in insulin signaling in liver and skeletal muscle of rat. Ann NY Acad Sci 1019: 448-452, 2004. 


\title{
Signal transducer and activator of transcription 3-regulated sarcoendoplasmic reticulum $\mathrm{Ca}^{2+}$-ATPase 2 expression by prolactin and glucocorticoids is involved in the adaptation of insulin secretory response during the peripartum period
}

\author{
Gabriel F Anhê, Tatiane C A Nogueira, José E Nicoletti-Carvalho, Camilo Lellis-Santos, Helena \\ C Barbosa ${ }^{2}$, José Cipolla-Neto, José R Bosqueiro ${ }^{1}$, Antonio C Boschero ${ }^{2}$ and Silvana Bordin \\ Laboratory of Molecular Biology, Department of Physiology and Biophysics, Institute of Biomedical Sciences, University of São Paulo (USP), Lineu Prestes \\ Avenue 1524, São Paulo 05508-900, Brazil \\ ${ }^{1}$ Laboratory of Endocrine Pancreas Physiology, Department of Biological Sciences, São Paulo State University (UNESP), Bauru, SP, Brazil \\ ${ }^{2}$ Laboratory of Endocrine Pancreas and Metabolism, Department of Physiology and Biophysics, Institute of Biology, State University of Campinas (UNICAMP), \\ Campinas, SP, Brazil \\ (Correspondence should be addressed to S Bordin; Email: sbordin@icb.usp.br)
}

\begin{abstract}
During pregnancy, the maternal endocrine pancreas undergoes, as a consequence of placental lactogens and prolactin (PRL) action, functional changes that are characterized by increased glucose-induced insulin secretion. After delivery, the maternal endocrine pancreas rapidly returns to nonpregnant state, which is mainly attributed to the increased serum levels of glucocorticoids (GCs). Although GCs are known to decrease insulin secretion and counteract PRL action, the mechanisms for these effects are poorly understood. We have previously demonstrated that signal transducer and activator of transcription 3 (STAT3) is increased in islets treated with PRL. In the present study, we show that STAT3 expression and serine phosphorylation are increased in pancreatic islets at the end of pregnancy (P19). STAT3 serine phosphorylation rapidly returned to basal levels 3 days after delivery (L3). The expression of the sarcoendoplasmic

reticulum $\mathrm{Ca}^{2+}$-ATPase 2 (SERCA2), a crucial protein involved in the regulation of calcium handling in $\beta$-cells, was also increased in P19, returning to basal levels at L3. PRL increased SERCA2 and STAT3 expressions and STAT3 Q1 serine phosphorylation in RINm5F cells. The upregulation of SERCA2 by PRL was abolished after STAT3 knockdown. Moreover, PRL-induced STAT3 serine phosphorylation and SERCA2 expression were inhibited by dexamethasone (DEX). Insulin secretion from islets of P19 rats pre-incubated with thapsigargin and L3 rats showed a dramatic suppression of first phase of insulin release. The present results indicate that PRL regulates SERCA2 expression by a STAT3dependent mechanism. PRL effect is counteracted by DEX and might contribute to the adaptation of maternal endocrine pancreas during the peripartum period.

Journal of Endocrinology (2007) 195, 1-12
\end{abstract}

\section{Introduction}

In pancreatic $\beta$-cells, the most prominent effect attributed to Janus kinase/signal transducer and activator of transcription 5 (JAK/STAT5) signaling pathway is the functional adaptation induced by placental lactogens (PL) and prolactin (PRL) during pregnancy (Brelje et al. 1993, Nielsen et al. 1999). The biological effects exerted by PRL in the endocrine pancreas are characterized by a marked increase in pancreatic $\beta$-cell proliferation and sensitivity to glucose, together with a decrease in apoptosis (Parsons et al. 1992, Scaglia et al. 1997, Bonner-Weir 2001).

The elevated concentration of glucocorticoids (GCs) found during the late stage of pregnancy is believed to counteract the PRL-induced adaptation of endocrine pancreas, reestablishing the non-pregnant phenotype in pancreatic $\beta$-cells. It has been demonstrated that dexamethasone (DEX), a synthetic glucocorticoid, reverses PRL-induced upregulation of islet Q1 function by inhibiting glucose metabolism (Shao et al. 2004), PDX-1 expression (Nasir et al. 2005), insulin secretion, and cell proliferation, and by increasing apoptosis (Weinhaus et al. 2000). Curiously, GCs have been reported to strongly synergize with PRL-induced STAT5 activation through distinct mechanisms involving the glucocorticoid receptor (Stocklin et al. 1996, Lechner et al. 1997, Wyszomierski et al. 1999). Therefore, a distinct mechanism activated by PRL, other than the activation of the JAK2/STAT5 pathway, is likely to be negatively modulated by GCs in pancreatic $\beta$-cells.

It is well known that the exocytosis of insulin-containing granules is tightly regulated by changes in cytosolic $\mathrm{Ca}^{2+}$ concentration. A disturbance in the $\mathrm{Ca}^{2+}$ sequestration by 
the endoplasmic reticulum (ER), as a result of a defect in sarcoER $\mathrm{Ca}^{2+}$-ATPase (SERCA) activity and expression, has been suggested as the cause of impaired insulin secretion in several animal models of glucose intolerance (Marie et al. 2001, Kulkarni et al. 2004), including the $d b / d b$ mice (Roe et al. 1994). $d b / d b$ Mice display obesity and type 2 diabetes, due to the absence of functional leptin receptors, the main activator of STAT3 in pancreatic $\beta$-cells (Shafrir 1992, Morton et al. 1999). We have demonstrated that adult pancreatic islets, cultured with PRL, show an upregulation in STAT3 gene expression (Bordin et al. 2004). It is noteworthy that STAT3 knockout mice develop abnormal islet architecture and an impairment in the early phase of glucoseinduced insulin secretion (Gorogawa et al. 2004) and glucose intolerance (Cui et al. 2004).

In the present study, we aimed to investigate whether the expression and phosphorylation status of STAT3 in pancreatic islets of pregnant and lactating rats correlates with the SERCA isoforms expression and, thus, with the insulin secretion pattern. We found that PRL induces SERCA2 expression in pancreatic $\beta$-cells through a STAT3-mediated mechanism. Additionally, we show that this phenomenon is inhibited by DEX.

\section{Materials and Methods}

\section{Materials}

General chemical reagents were obtained from Synth (Diadema, SP, Brazil). RPMI-1640 medium, trypsin, and fetal bovine serum (FBS) were from Cultilab (Campinas, SP, Brazil). BSA (fraction V), collagenase type V, Tris, dithiothreitol, luminol, p-coumaric acid, and thapsigargin were from Sigma. Rat PRL was purchased from Dr A F Parlow (Harbor University of California Los Angeles Medical Center, USA). DEX disodium phosphate was from Laboratórios Aché (São Paulo, SP, Brazil). The apparatus for SDSPAGE was from Bio-Rad. The nitrocellulose membranes

Q2 were from Bioagency (São Paulo, SP, Brazil). Antibodies against STAT3 (sc483), STAT5 (sc835), pSTAT3-Tyr (sc8059), SERCA2 (sc8095), SERCA3 (sc8097), $\boldsymbol{\alpha}$-tubulin (sc-8035), and HRP-conjugated and anti-goat were from Santa Cruz Technology (Santa Cruz, CA, USA). The antibody against pSTAT3-Ser (9134) was from Cell Signaling (Danvers, MA, USA). [ ${ }^{125}$ I]Insulin, HRP-conjugated antirabbit and anti-mouse antibodies were from Amersham-

Q3 Pharmacia Biotech. X-ray sensitive films and chemicals were from IBF (Rio de Janeiro, RJ, Brazil). GoTaq DNA polymerase and ImProm-II reverse transcriptase were from

Q3 Promega. PCR primers and phosphorothioate scrambled and

Q1 antisense oligonucleotides were from IDT-Integrated DNA

Q3 Technologies (Coralville, IA, USA). Opti-MEM, random primers, dNTP set, agarose, Trizol reagent, antibiotics, antimicotic, and Lipofectamine 2000 were from Invitrogen.
All plastics for cell culture were from TPP (Trasadingen, Switzerland).

\section{Animals and islet isolation}

Two female rats and one male rat were housed together for 5 days. The presence of spermatozoa in the vaginal wash indicated day 0 of gestation. Immediately after delivery, the number of pups was adjusted to eight for each lactating mother. Pregnant and lactating rats were killed at 19 days post-coitus (P19) and 3 and 8 days post partum (L3 and L8 respectively). Virgin age-matched rats were used as the control group (CTL). Islets were isolated by collagenase digestion, as previously described (Bordin et al. 1995). All of the experiments involving animals were in accordance with the guidelines of the Brazilian College for Animal Experimentation.

\section{Insulin secretion}

Cumulative insulin secretion was performed in pancreatic islets from female virgin rats after a 36-h culture. Previously to the culture, groups of 300 islets were transfected with ASO

Q1 against STAT3 (ASO) or treated only with Lipofectamine 2000. After culture, groups of five islets were first incubated for $30 \mathrm{~min}$ at $37^{\circ} \mathrm{C}$ in Krebs-bicarbonate buffer containing $5.6 \mathrm{mM}$ glucose and equilibrated with $95 \% \mathrm{O}_{2} / 5 \% \mathrm{CO}_{2}(\mathrm{pH}$ $7 \cdot 4)$. The solution was then replaced by fresh Krebsbicarbonate buffer and the islets were incubated for a further $60-$ min period with medium containing 2.8 or $16.7 \mathrm{mM}$ glucose. After the incubation period, the supernatant was kept for insulin determination.

Insulin secretion in dynamic conditions was performed, as previously described (Bosqueiro et al. 2000). Briefly, groups of 20 islets were isolated from CTL, P19, and L3 rats, transferred to chambers, and perfused for $30 \mathrm{~min}$ with Krebsbicarbonate containing $2.8 \mathrm{mM}$ glucose. A group of islets isolated from P19 rats was also pre-incubated with $5 \mu \mathrm{M}$ thapsigargin for $20 \mathrm{~min}$ before the beginning of perfusion. The medium was then changed to Krebs-bicarbonate containing $16.7 \mathrm{mM}$ glucose and the islets were perfused for an additional $30 \mathrm{~min}$. The effluent was collected every $1 \mathrm{~min}$ from the min 20 until the end of the perfusion period. Since islets from P19 rats are usually larger than CTL and L3 islets, dynamic insulin secretion are expressed relative to insulin content. For this, the islets were sonicated in lysis buffer $(70 \%$ ethanol and $0 \cdot 2 \mathrm{M} \mathrm{HCl})$ and incubated overnight at $4{ }^{\circ} \mathrm{C}$. The insulin content of each sample was measured by RIA using rat insulin as a standard.

\section{RINm $5 F$ cells and isolated islets culture, treatment, and transfection}

Islets and RINm5F cells were cultured in RPMI-1640 medium containing $11 \mathrm{mM}$ glucose, $10 \% \mathrm{FBS}$, and penicillin and streptomycin in a humidified atmosphere with 5\% CO2 at 
$37^{\circ} \mathrm{C}$. PRL and DEX were added to final concentrations of

Q3 $500 \mathrm{ng} / \mathrm{ml}$ and $100 \mathrm{nM}$ respectively. PRL was added to the medium $6 \mathrm{~h}$ prior to DEX. RINm5F cell treatment was carried out in serum-free medium containing 1\% BSA, and islets in medium containing 10\% FBS; $24 \mathrm{~h}$ after treatment,

Q3 cells were used to western blot and islets to RNA extraction. For transfection, Opti-MEM containing $10 \mathrm{mM}$ glucose plus a chimeric DNA-RNA 2'-O-methyl phosphorothioate oligonucleotide, previously mixed with Lipofectamine 2000, was added to RINm5F cells and isolated islets. CTL cells and islets were treated only with Lipofectamine. The oligonucleotides used for transfection were a scrambled oligonucleotide (S) with no effect on STAT3 expression, and an antisense oligonucleotide targeted to STAT3 (ASO). After $4 \mathrm{~h}$, the medium was supplemented with RPMI containing 1\% BSA with or

Q3 without PRL. After $24 \mathrm{~h}$, total protein was extracted and processed for western blotting. The sequences of the $\mathrm{S}$ and ASO oligonucleotides were $5^{\prime}$-GmCmUmGCTGGAGCTGGmUmUmCmC-3', and $5^{\prime}-\mathrm{mGmCmAmC}-$ GATCGATCCCmCmAmUmG-3' respectively where ' $\mathrm{m}$ ' denotes RNA $2^{\prime}$-O-methyl nucleotides.

\section{RT-PCR analysis}

Total RNA was extracted from 24-h cultured islets using Trizol reagent. RT-PCR was performed as previously described (Bordin et al. 2004). The primer sets used in RT-PCR analysis, with their respective melting temperatures and product lengths, were:

Q1 GLUT2: 5'-CATTGCTGGAAGAAGCGTATCAG-3' and 5'-GAGACCTTCTGCTCAGTCGACG- $3^{\prime}, 55^{\circ} \mathrm{C}, 408 \mathrm{bp}$; SUR1: $5^{\prime}$-TTCCACATCCTGGTCACACCG- $3^{\prime}$ and $5^{\prime}$-AGAAGGAGCGAGGACTTGCCAC- $3^{\prime}, 60^{\circ} \mathrm{C}, 425 \mathrm{bp}$; SERCA2: $5^{\prime}$-CTCTGGGTCAATCTGGTGACGG-3' $3^{\prime}$ and $5^{\prime}$-TGCCATTGTCATCGGATACGG- $3^{\prime}, 58^{\circ} \mathrm{C}, 324 \mathrm{bp}$; and RPL37a: $5^{\prime}$-CAAGAAGGTCGGGATCGTCG- $3^{\prime}$ and $5^{\prime}$-ACCAGGCAAGTCTCAGGAGGTG-3', $57^{\circ} \mathrm{C}, 290 \mathrm{bp}$. The RNAs used for RT-PCR analysis were obtained from three or four independent experiments.

\section{Western blot analysis}

Freshly isolated pancreatic islets and RINm5F cells were homogenized in $100 \mu \mathrm{l}$ of solubilization buffer and processed for protein extraction and western blot, as previously described (Anhêet al. 2006). Before incubation with the primary antibody, the membranes were blocked with blocking buffer (5\% nonfat dried milk, $10 \mathrm{mM}$ Tris, $150 \mathrm{mM} \mathrm{NaCl}$, and $0 \cdot 02 \%$ Tween 20) for $2 \mathrm{~h}$ at $22^{\circ} \mathrm{C}$. The membranes were incubated for $4 \mathrm{~h}$ at $22{ }^{\circ} \mathrm{C}$ with the primary antibody diluted in blocking buffer with $3 \%$ nonfat dried milk. After being washed for $30 \mathrm{~min}$ in blocking buffer without milk, the membranes were incubated with peroxidase-conjugated secondary antibody for $1 \mathrm{~h}$, and processed for chemiluminescence to visualize the immunoreactive bands. Quantitative analysis of the blots was performed by Scion Image software. When the primary antibody was a goat polyclonal, nonfat dried milk was replaced by $1 \%$ gelatin in all incubations.

\section{Statistical analysis}

The results were expressed as the mean \pm s.E.M. The results were compared using ANOVA followed by the TukeyKramer test or Student's unpaired $t$-test. $P$ values $<0.05$ indicated a significant difference.

\section{Results}

STAT3 expression and phosphorylation in pancreatic islets during pregnancy and lactation

Our results show that the protein content of STAT3 is increased in pancreatic islets at end of the gestational period (1.5-fold for P19 compared with CTL; $P<0 \cdot 05)$. This increase persisted until day 3 of lactation $(1 \cdot 4$-fold for L3 compared with CTL; $P<0 \cdot 05)$ returning to control values on day 8 (L8; Fig. 1A). Tyrosine phosphorylation of STAT3 was not altered throughout the referred periods (Fig. 1B). STAT3 serine phosphorylation was increased in pancreatic islets from late pregnant rats $(2 \cdot 1$-fold for P19 compared with CTL; $P<0 \cdot 05)$. The higher levels of STAT3 serine phosphorylation were temporally limited to pregnancy and returned to CTL values in L3 rats (Fig. 1C).

\section{Dynamic insulin secretion by pancreatic islets from pregnant and lactating rats}

In islets from pregnant and virgin rats, the introduction of $16.7 \mathrm{mM}$ glucose in the perfusion medium induced a biphasic insulin secretory response characterized by a prominent and transient release (first phase) followed by a secondary rise (Fig. 2). As expected, overall secretion from pregnant rat islets during the stimulatory period was higher than that of the control. After parturition, total insulin secretion, measured Q4 over the stimulatory period (31-60 min), returned to values found in non-pregnant rat islets. However, the first-phase release in islets from lactating rats at L3 was abolished $(P<0 \cdot 05$ compared with CTL and P19).

SERCA2 and SERCA3 expressions in pancreatic islets during pregnancy and lactation and participation of SERCA in the insulin secretion during pregnancy

The protein content of SERCA3 was similar in pancreatic islets from P19, L3, and CTL (Fig. 3A). However, SERCA2 was significantly increased in pancreatic islets from P19 rats, returning to CTL values in L3 rats $(2 \cdot 7$-fold for P19 compared with CTL; $P<0 \cdot 05$; Fig. 3B). In order to clarify the role of this ERCA2 in the dynamic feature of insulin secretion during pregnancy, we treated pancreatic islets from P19 rats with thapsigargin, an irreversible SERCA inhibitor. 
A

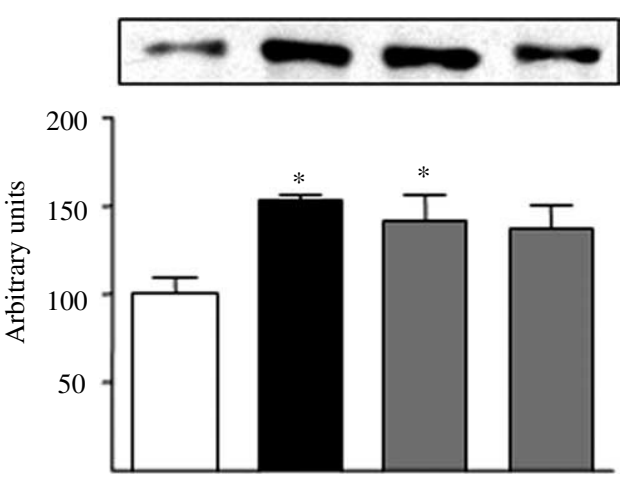

B

IB: pSTAT3-(Tyr)

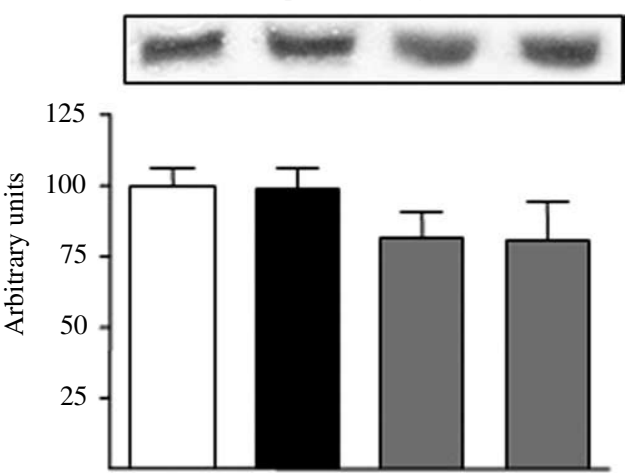

C

IB: pSTAT3-(Ser)

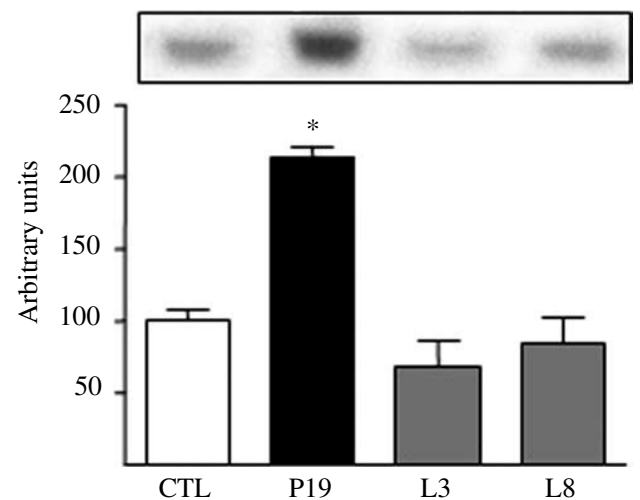

Figure 1 STAT3 expression, serine, and tyrosine phosphorylation in pancreatic islets from pregnant and lactating rats. Pancreatic islets were isolated from pregnant (P19) and lactating (L3 and L8) rats. Protein extracts were processed for western blotting for STAT3 (A; $n=5)$, pSTAT3-Tyr $(B ; n=5)$ and pSTAT3-Ser $(C ; n=8)$. The bars represent the means \pm S.E.M. of the values determined by optical densitometry. ${ }^{*} P<0 \cdot 05$ versus CTL.

Figure 3C shows that pharmacological blockade of SERCA in pancreatic islets from $\mathrm{P} 19$ rats resulted in a significant

Q3 reduction of the first phase of insulin secretion $(P<0 \cdot 05)$. In contrast, the secondary rise in insulin secretion from P19 islets treated with thapsigargin showed a tendency to be higher than P19 islets that were pre-incubated only with glucose.

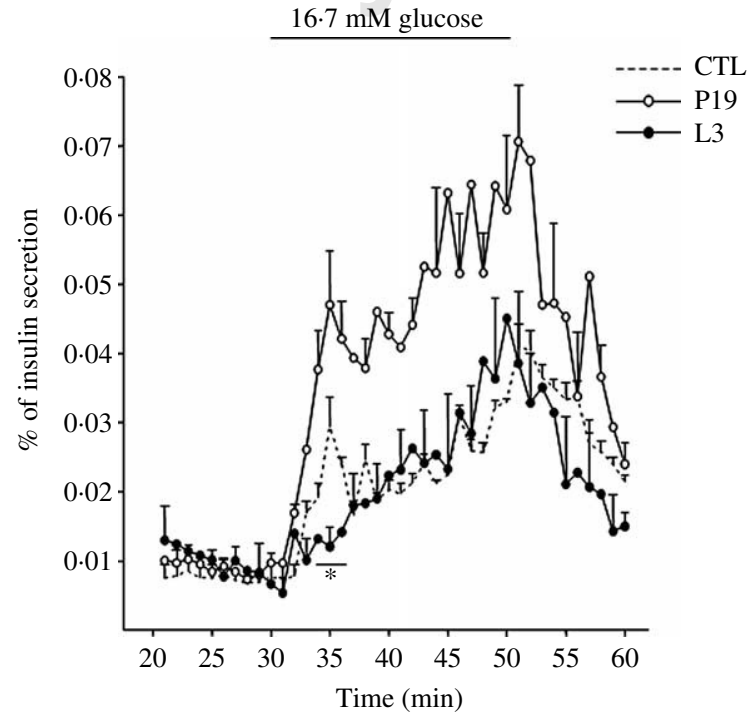

Figure 2 Dynamic insulin secretion by pancreatic islets from pregnant and lactating rats. Groups of 20 islets were isolated from CTL, P19, and L3 rats, transferred to chambers, and perfused with Krebs-bicarbonate containing $2 \cdot 8 \mathrm{mM}$ glucose for the initial $30 \mathrm{~min}$. The medium was replaced by a solution containing $16 \cdot 7 \mathrm{mM}$ glucose for an additional $30 \mathrm{~min}$ of perfusion. The dotted line represents insulin secretion from CTL rat islets. Continuous lines with open and black circles represent insulin secretion from P19 and L3 rat islets respectively. Mean values ( \pm s.E.M.) refer to four individual experiments. ${ }^{*} P<0 \cdot 05$ versus CTL.

Specificity and efficiency of the phosphorothioate antisense Q3 oligonucleotide targeted to STAT3

Q3 Western blot analysis in RINm5F cells transfected with antisense phosphorothioate oligonucleotide targeted to STAT3 (ASO) revealed that this oligo efficiently reduces STAT3 protein content without any interference in STAT5 and $\boldsymbol{\alpha}$-tubulin expressions. Additionally, the effect of ASO is not due to a non-specific effect, since the transfection with the scrambled control oligo (S) did not cause any disruption in

Q3 STAT3 expression (Fig. 4A). As observed in pancreatic islets from STAT3-knockout mice (Gorogawa et al. 2004), GLUT2 (0.63-fold for ASO compared with CTL; $P<0 \cdot 05)$ and SUR1 (0.60-fold for ASO compared with CTL; $P<0 \cdot 05)$ mRNA expressions were decreased in RINm5F cells transfected with ASO (Fig. 4B and C respectively).

RINm5F cells treated with PRL for $24 \mathrm{~h}$ displayed an increase in STAT3 protein content (1.9-fold compared with CTL; $P<0 \cdot 05)$. Transfection with ASO reduced STAT3 content $(0 \cdot 38$-fold compared with CTL; $P<0 \cdot 05)$ and abolished the PRL-induced increase in STAT3 (Fig. 4D).

Modulation of SERCA2, but not SERCA3, by PRL in RINm5F cells and the participation of STAT3

Figure 5A shows that PRL induced an increase in the SERCA2 content of RINm5F cells (1.59-fold compared with CTL; $P<0 \cdot 05)$, while transfection with ASO reduced the SERCA2 
A
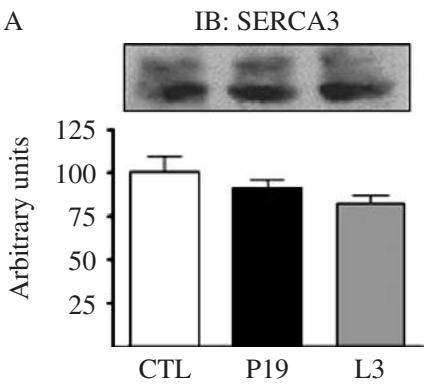

B
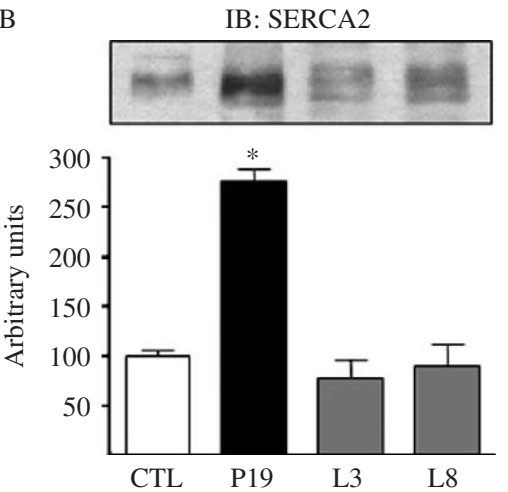

C

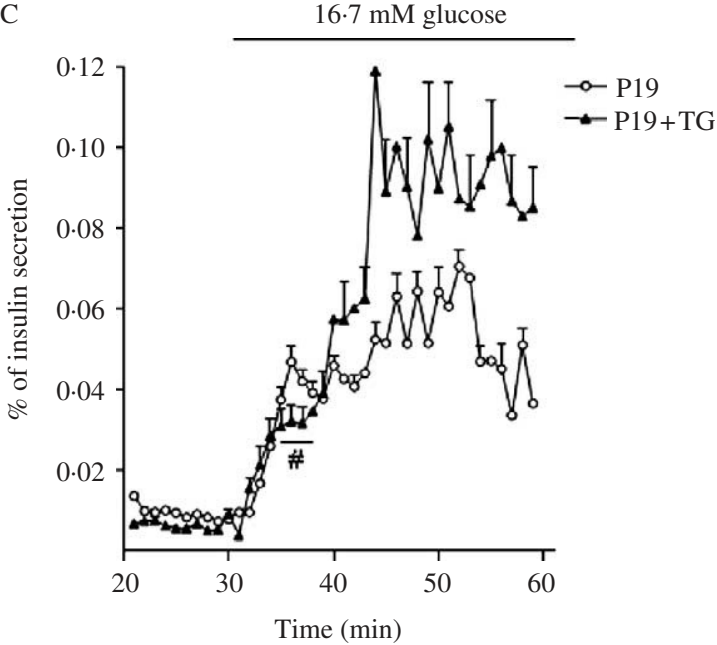

Figure 3 Participation of SERCA in insulin secretion during pregnancy and its expression in pancreatic islets from pregnant and lactating rats. Pancreatic islets were isolated from pregnant (P19) and lactating (L3 and L8) rats. Protein extracts were processed for western blot detection of SERCA3 $(\mathrm{A} ; n=3)$ and SERCA2 (B; $n=4)$. Groups of 20 islets were isolated from P19 rats and pre-incubated with (P19+TG) or without (P19) $5 \mu M$ thapsigargin for $20 \mathrm{~min}$ before the beginning of perfusion. After this period, the islets were transferred to chambers and perfused with Krebs-bicarbonate containing $2.8 \mathrm{mM}$ glucose for the initial $30 \mathrm{~min}$. The medium was replaced by a solution containing $16 \cdot 7 \mathrm{mM}$ glucose for an additional 30 min of perfusion. Open circles represent P19 islets and black triangles represent P19 islets pre-incubated with TG $(C ; n=4)$. The bars and the lines represent the means \pm s.E.M. of the values. ${ }^{*} P<0 \cdot 05$ versus $C T L ;{ }^{*} P<0.05$ versus $\mathrm{P} 19$ in the absence of TG.

content $(0 \cdot 46$-fold compared with CTL; $P<0 \cdot 05)$. The upregulation of SERCA2 was not observed in RINm5F cells treated with PRL and previously transfected with ASO targeted to STAT3. The effect of PRL on RINm5F cells was specific for SERCA2 since no differences were found in SERCA3 expression (Fig. 5B). Figure 5C shows that the knockdown of STAT3 expression prompts to an increase in the 1 -h cumulative insulin secretion induced by glucose $(P<0 \cdot 05$ versus CTL islets with $16.7 \mathrm{mM}$ glucose), without any effect on the basal $(2 \cdot 8 \mathrm{mM}$ glucose) insulin secretion.

Combined effect of DEX and PRL on STAT3 expression and phosphorylation in RINm $5 \mathrm{~F}$ cells

Figure 6A shows that PRL alone or in combination with DEX promoted a similar increase in the STAT3 content in RINm5F cells (1.95-fold for PRL and 2.00-fold for DEX + PRL when compared with CTL; $P<0 \cdot 05)$. DEX alone did not alter STAT3 expression in RINm5F cells. Tyrosine phosphorylation of STAT3 was not altered by PRL, DEX, or the combination of both agents (Fig. 6B).
STAT3 serine phosphorylation was increased in RINm5F cells treated with PRL (1.30-fold compared with CTL; $P<0 \cdot 05)$. DEX alone, or in combination with PRL, reduced the levels of STAT3 serine phosphorylation $(0 \cdot 60$-fold for DEX and DEX + PRL compared with CTL; $P<0 \cdot 05$; Q3 Fig. 6C).

Combined effect of DEX and PRL on SERCA2 protein and $m R N A$ expression in RINm $5 F$ cells and cultured rat pancreatic islets

Figure 7A shows that PRL-induced SERCA2 expression in RINm5F cells was abolished by the presence of DEX. Additionally, DEX alone promoted a reduction in SERCA2 content in RINm5F cells $(0 \cdot 75$-fold compared with CTL; $P<0 \cdot 05)$. Figure $7 \mathrm{~B}$ shows that $\mathrm{PRL}$ also induced an increase in SERCA2 mRNA in cultured rat pancreatic islets $(1 \cdot 20-$ fold compared with CTL; $P<0 \cdot 05)$. This effect was also counteracted by the addition of DEX to the culture medium and, in this case, DEX alone did not reduce SERCA2 expression (Fig. 7B).

Journal of Endocrinology (2007) 195, 1-12 
A

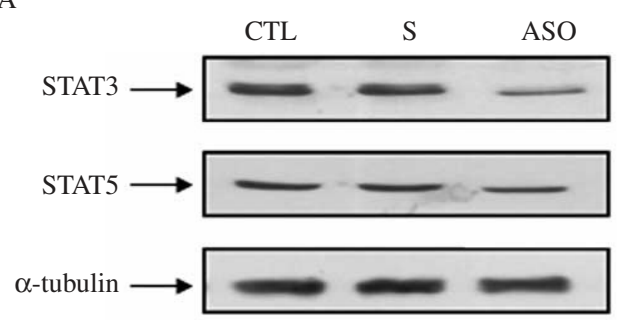

B

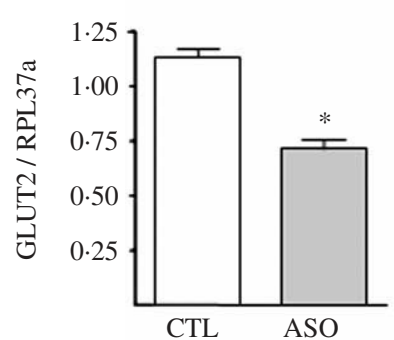

C

$\mathrm{D}$

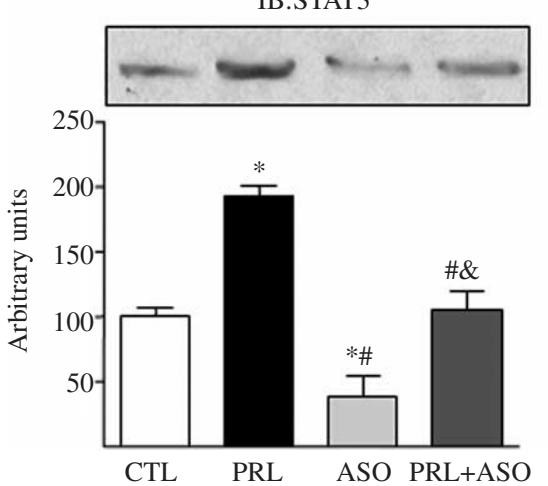

Figure 4 STAT3 knockdown in RINm5F cells treated with prolactin. Q3 RINm5F cells were transfected with a phosphorothioate oligonucleotide targeted to STAT3 (ASO) and with a scrambled oligonucleotide with no effect on STAT3 expression (S). CTL cells were

Q3 treated only with the Lipofectamine. After $24 \mathrm{~h}$ from the transfection, the cells were processed for western blot detection of STAT3, STAT5, and $\alpha$-tubulin (A) and for RT-PCR of GLUT2 (B; $n=7$ ) and SUR1 (C; $n=5)$ genes. After the transfection, a distinct group of cells (ASO and CTL), were transferred to a $1 \%$ BSA medium in the

Q3 presence or in the absence of PRL. After $24 \mathrm{~h}$, the cells were processed for western blot detection of STAT3 (D; $n=7)$. The bars represent the means \pm S.E.M. of the values determined by optical densitometry. ${ }^{*} P<0 \cdot 05$ versus $\mathrm{CTL} ;{ }^{*} P<0 \cdot 05$ versus $\mathrm{PRL}$ and ${ }^{\&} P<0 \cdot 05$ versus ASO.

\section{Discussion}

We have previously demonstrated that in vitro treatment of pancreatic islets with PRL increases STAT3 expression (Bordin et al. 2004). Attempting to investigate the participation of STAT3 in a physiological situation in which the high levels of PRL are determinant for the adaptation of the endocrine pancreas, we first examined STAT3 expression and phosphorylation status in islets from pregnant and lactating rats. STAT3 expression was increased in pancreatic islets from P19 and L3 rats. Since PRL serum levels remain high during the transition from late pregnancy to early lactation (Kawai \& Kishi 1999), it is reasonable to assume that modulation of STAT3 expression during the peripartum may be due to PRL action. We also found that serine, but not tyrosine basal phosphorylation of STAT3, is increased in the pancreatic islets of late pregnant rats. Thus, the current study aimed to clarify the putative participation of STAT3 and its serine phosphorylation in the physiology of pancreatic islets during pregnancy.

The increase in STAT3 serine phosphorylation was also detected in RINm5F cells treated with PRL. Taken together, the in vivo and in vitro data of the present study strongly indicate that PRL may modulate not only STAT3 expression, but also its serine phosphorylation. In accordance to our results, Neilson and collaborators have recently shown that PRL induces direct activation of STAT3 after a 24-h treatment (Neilson et al. 2007). Interestingly, insulin has also been reported to stimulate STAT3 serine phosphorylation

Q3 (Ceresa \& Pessin 1996). PRL increases insulin secretion from isolated pancreatic islets (Sorenson et al. 1993, Crepaldi et al. 1997), and high serum insulin levels present in late pregnancy return to normal levels on day 1 after delivery (Kawai \& Kishi 1999). Thus, the hypothesis that PRL increases STAT3 serine phosphorylation indirectly through the modulation of insulin secretion must also be considered to explain the results showed herein.

Although it is classically recognized that tyrosine phosphorylation of STAT3 is a prerequisite for the activation of gene transcription (Aaronson \& Horvath 2002), the role of serine phosphorylation in the regulation of STAT3 activity remains controversial. Recent evidence suggests that STAT3

Q1 serine phosphorylation, which occurs within a MAPK consensus site (Ser727), has a positive role in STAT3 transcriptional activation (Shen et al. 2004, Kojima et al. 2005, Sun et al. 2006). Indeed, extracellular signal-regulated protein kinases (ERKs) activation targets STAT3 serine phosphorylation (Kuroki \& O'Flaherty 1999, O'Rourke \& Shepherd 2002). We have previously demonstrated that PRL activates ERK1/2 in vitro in isolated islets (Amaral et al. 2003) and in vivo in islets from pregnant rats (Amaral et al. 2004). Therefore, we may speculate that PRL may target STAT3 serine phosphorylation in pancreatic islets by activation of ERK1/2. This can occur by a direct action of PRL or as the consequence of the increased insulin circulating levels, since insulin-induced STAT3 serine phosphorylation is ERK1/2 dependent (Ceresa et al. 1997).

The dynamics of insulin secretion by pancreatic islets from pregnant rats showed that, during pregnancy, there is a marked increase in glucose response. This result is in accordance with classical studies that report an increased insulin secretion from late pregnant rats (Green \& Taylor 1972, Lipson \& Sharp 1978). The upregulation of both the first and the second phases is no longer observed in early 
A IB:SERCA2

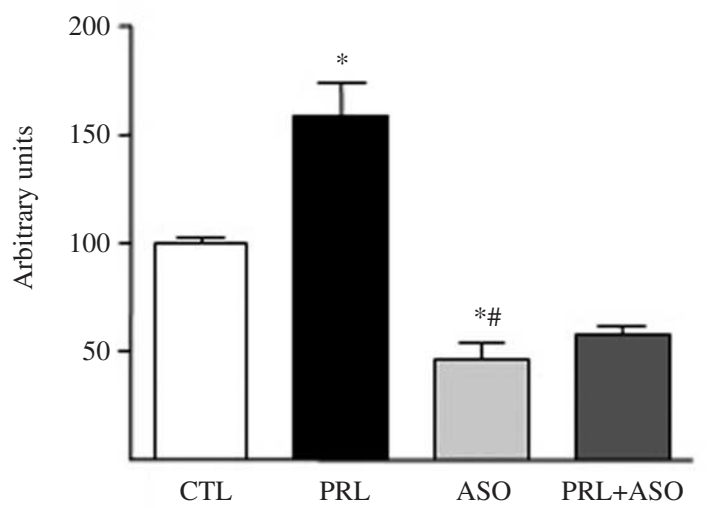

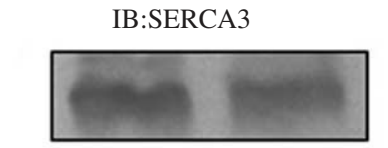

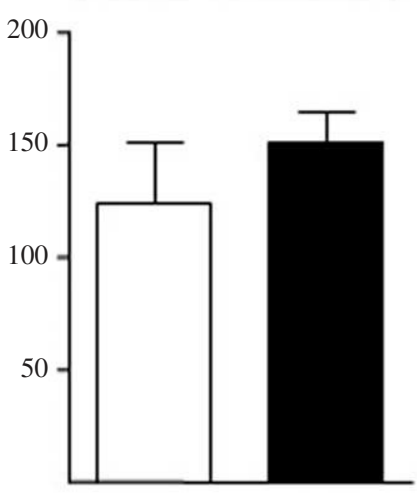

CTL

PRL

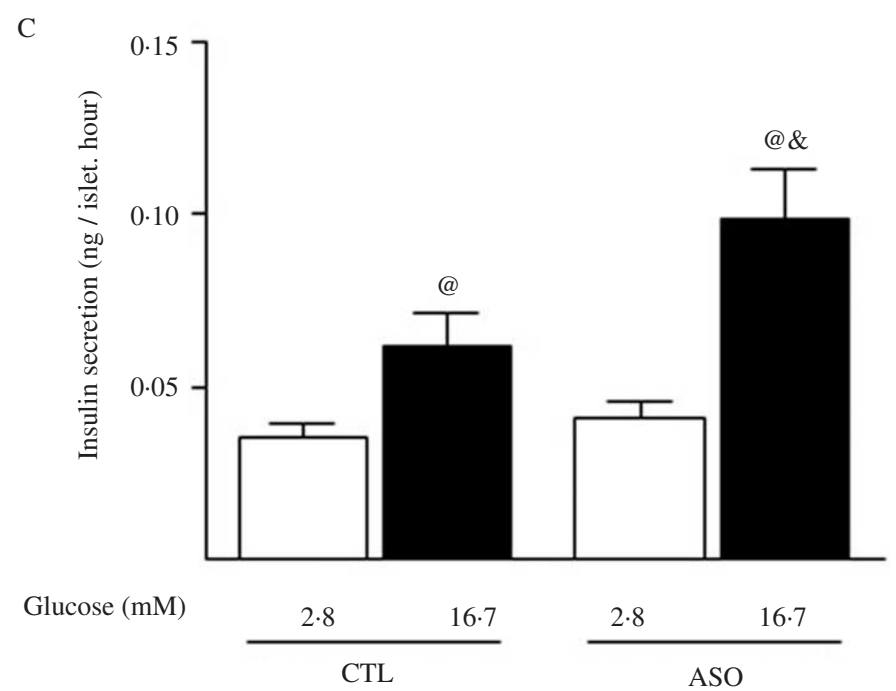

Figure 5 Effect of PRL and STAT3 knockdown on SERCA2 and SERCA3 expressions in RINm5F cells and insulin secretion in isolated pancreatic islets. CTL RINm5F cells and ASO transfected cells were transferred to

Q3 a 1\% BSA medium in the presence or absence of PRL. After $24 \mathrm{~h}$, the cells were processed for western blot detection of SERCA2 $(\mathrm{A} ; n=5)$. Cells treated with PRL were also processed for western blot detection of SERCA3 (B; $n=3$ ). Groups of 300 pancreatic islets from virgin female rats were cultured overnight and transiently transfected with antisense oligonucleotide against STAT3 (ASO). CTL islets were treated only with Lipofectamine 2000. After 36 h of culture, islets were used for insulin secretion assay $(C ; n=12)$. The results represent the relative expressions of SERCA2 and SERCA3 as determined by optical densitometry, and the 1-h cumulative insulin secretion by RIE. Data are presented as mean \pm s.E.M. ${ }^{*} P<0 \cdot 05$ versus CTL; ${ }^{\#} P<0 \cdot 05$ versus PRL; ${ }^{\circledR} P<0.05$ versus glucose $2.8 \mathrm{mM}$ within the same condition; ${ }^{\&} P<0.05$ versus $C T L$ in the presence of glucose $16.7 \mathrm{mM}$.

lactating rats. Indeed, the first phase was almost abolished after parturition. Whilst it has been previously reported that the insulin secretory response to glucose returns to control values during early lactation (Hubinont et al. 1986, Kawai \& Kishi 1999), the dynamic insulin secretion pattern has not been demonstrated. The return of the secretory response to a non-pregnant state is believed to occur due to a decrease in the rapid exchangeable islet calcium pool (Hubinont et al. 1986, Hubinont \& Malaisse 1987). The increase in SERCA2, but not SERCA3, in islets from pregnant rats and its immediate reduction on day 3 of lactation might be a mechanism by which the reduction in intracellular calcium 
A

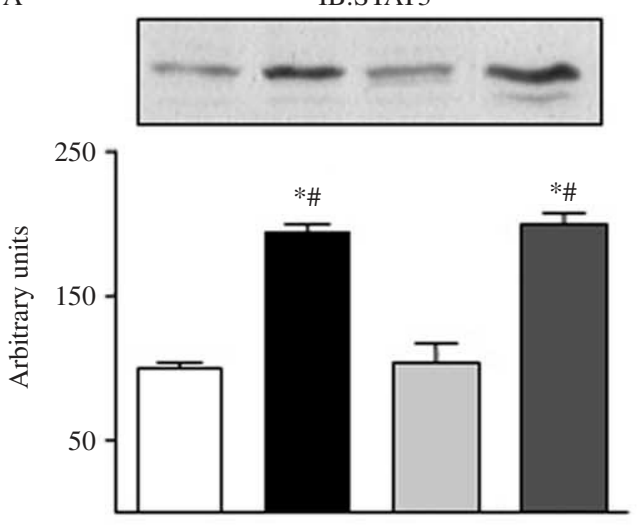

B
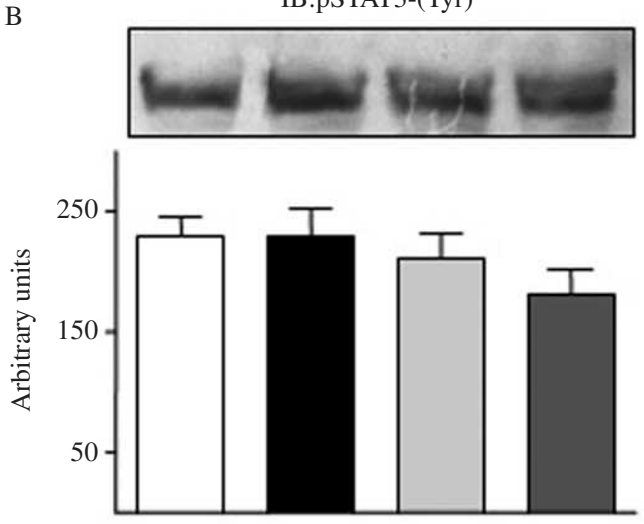

C
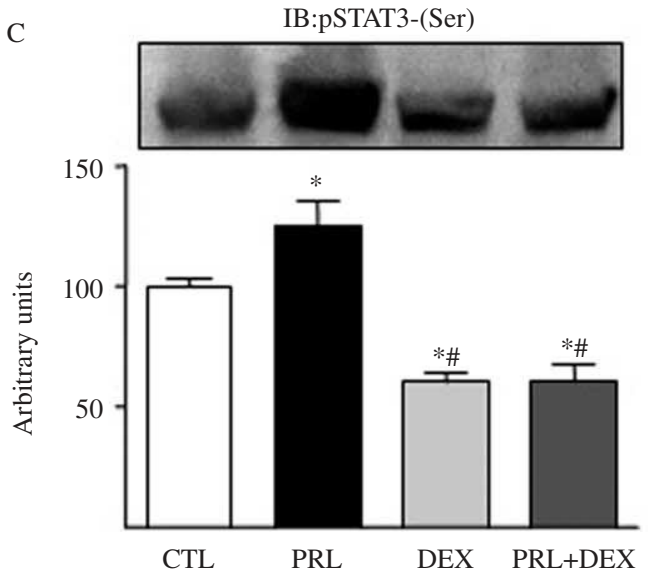

Figure 6 Effect of DEX and PRL on STAT3 expression, and serine and tyrosine phosphorylation in RINm5F cells. RINm5F cells were treated with PRL and DEX alone or combined (PRL + DEX) for $24 \mathrm{~h}$. After the treatment, cells were processed for protein extraction and western blot detection of STAT3 (A), pSTAT3-Tyr (B), and pSTAT3Ser (C). The bars represent the means \pm S.E.M. of the values determined by optical densitometry. ${ }^{*} P<0 \cdot 05$ versus CTL; ${ }^{\sharp} P<0 \cdot 05$ versus PRL; $n=7$. occurs in islets from lactating rats. This hypothesis is reinforced here by the significant decrease in the first phase of insulin secretion in pancreatic islets of P19 rats after the pharmacological inhibition of SERCA. Therefore, our results corroborate the former postulation of Hubinont \& Malaisse (1987) that a depletion of endogenous calcium stores accounts, at least in part, for the decreased insulin secretory responsiveness to glucose in lactation. Additionally, our results suggest that calcium stores in pancreatic islets from pregnant rats, which might result from increased SERCA2 content, also play a role in the upregulation of first phase of insulin secretion during late pregnancy.

Gorogawa et al. (2004) have shown that the disruption of the STAT3 gene in $\beta$-cells (STAT3-insKO mice) resulted in an impairment of the first phase of glucose-stimulated insulin secretion. It is well known that $\mathrm{Ca}^{2+}$ handling in pancreatic $\beta$-cells plays an important role in the regulation of insulin secretion. Diminished SERCA expression and activity has been described as a common dysfunction related to the poor insulin secretion observed in animal models of diabetes (Roe et al. 1994, Varadi et al. 1996, Levy et al. 1998, Marie et al.
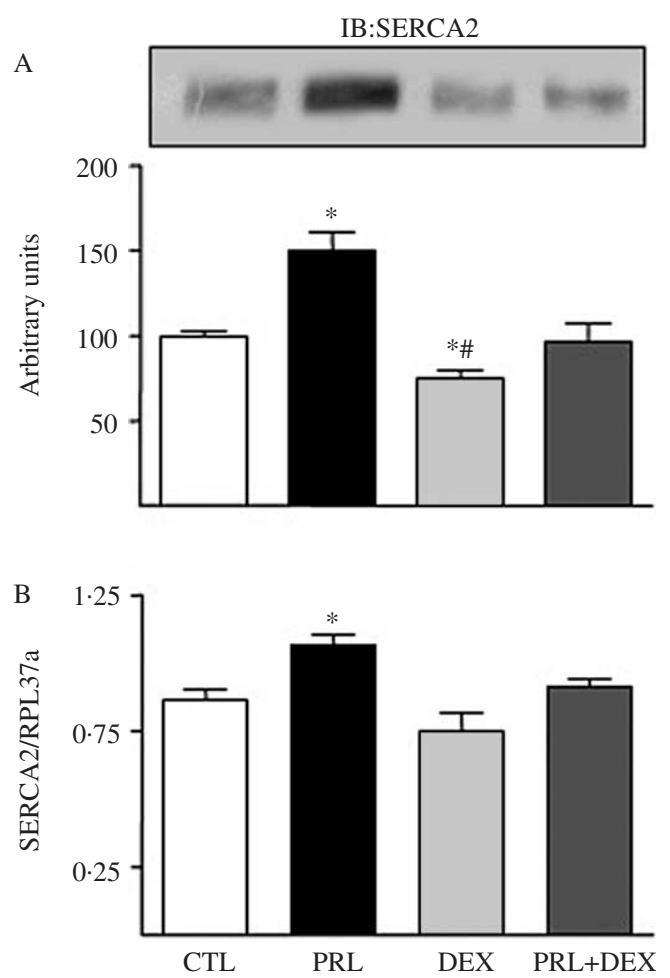

Figure 7 Effect of DEX and PRL on SERCA2 expression in RINm5F cells and pancreatic islets. RINm5F cells and islets were treated with PRL and DEX alone or combined (PRL + DEX) for $24 \mathrm{~h}$. After the treatment, RINm5F cells were processed for protein extraction and western blot detection of SERCA2 (A), and pancreatic islets were processed for total RNA extraction and RT-PCR analysis of SERCA2 mRNA using RPL37a as housekeeping gene (B). The bars represent the means \pm s.E.M. of the values determined by optical densitometry. ${ }^{*} P<0 \cdot 05$ versus CTL; ${ }^{\sharp} P<0 \cdot 05$ versus PRL; $n=4$. 
2001, Kulkarni et al. 2004). Although both SERCA2 and SERCA3 isoforms are co-expressed in human and rat islets and in the RINm5F $\beta$-cell line (Varadi et al. 1996), several studies have suggested a central role for SERCA3 in $\beta$-cell function. The absence of SERCA3, however, is insufficient to alter glucose homeostasis or impair insulin secretion (Arredouani et al. 2002a). Moreover, SERCA2 instead of SERCA 3 is involved in resting $\left[\mathrm{Ca}^{2+}\right]$ i regulation in $\beta$-cells, which implicates SERCA2 as the primary ERCA2 in physiological conditions (Varadi \& Rutter 2002). Corrobor-

Q5 ating our data, Crepin et al. (2007) have recently demonstrated that the expression of SERCA2 is upregulated by PRL in immortalized epithelial prostatic cells.

In order to investigate whether this marked and reciprocal temporal pattern of STAT3 serine phosphorylation and SERCA2 expression observed in vivo was directly correlated to PRL effects on $\beta$-cell, we examined SERCA2 expression in the $\beta$-cell lineage, RINm5F, treated with PRL after the knockdown of STAT3 gene expression. Similarly to the study of Crepin et al. (2007), PRL also stimulated SERCA2 expression in RINm5F cells. STAT3 knockdown diminished SERCA2 expression in RINm5F cell and abolished PRLinduced SERCA2 expression, indicating that SERCA2 is regulated by STAT3. Additionally, PRL had no effect on SERCA3 expression. Our results also show that the knockdown of STAT3 expression induces, rather than inhibits, a significant increase in cumulative insulin secretion from pancreatic islets. This effect is in accordance with the dynamic insulin secretion of P19 islets treated with thapsigargin. The pharmacological blockage of SERCA induces a significant decrease in first phase of insulin secretion but promoted a tendency to increase the second phase, which might result in an overall increase in the cumulative insulin secretion.

Although apparently contradictory, these results agree with several reports showing that SERCA pump inhibition results in an increase in the amplitude of the glucose-triggered $\mathrm{Ca}^{2+}$ transients, membrane depolarization, and insulin exocytosis (Arrredouani et al. 2002a,b, Cruz-Cruz et al. 2005, Beauvois et al. 2006, Hughes et al. 2006). Moreover, in islets isolated from mice deficient in SERCA3 (the isoform predominantly expressed in mouse pancreatic $\beta$-cells), the glucose-stimulated insulin secretion is greater than those from the wild type (Arredouani et al. 2002a). Thus, we suggest that knockdown of STAT3, and by extension SERCA2, would decrease the first phase of insulin secretion (which corresponds for $\sim 2 \%$ of total amount of insulin secreted granules) and increase the second phase

Q3 (corresponding to $98 \%$ of the total granules secreted). The overall response of this effect can be detected as an increase in cumulative insulin secretion during a 1-h assay.

In this way, we suggest that the STAT3-mediated SERCA2 expression, showed in the present study, is a mechanism by which PRL may contribute to the increased glucose-induced first phase of insulin secretion during pregnancy. Additionally, these data corroborate previous findings that have correlated the loss of the secretory response in $\mathrm{db} / \mathrm{db}$ mice with decreased
SERCA activity (Roe et al. 1994). Importantly, the recovery of Q1 the secretory response in ZDF rats by overexpression of functional leptin receptors occurs simultaneously to a striking increase in the STAT3 phosphorylation status (Wang et al. 1998).

The understanding of the mechanisms that regulate early phase of glucose-induced insulin secretion is particularly relevant because subjects with type 2 diabetes show a defective dynamic of insulin release due to a preferential reduction on first-phase insulin secretion (reviewed by Ahrén 2005). The impairment of the first phase of insulin release frequently found in diabetic patients extends the duration of postprandial hyperglycemia and, as a consequence, stimulates a compensatory late-phase hyperinsulinemia (Caumo \& Luzi 2004). Anatomically, the liver is the main target for first-phase insulin secretion. As the secreted insulin reaches circulation through the portal system, a greater hepatic than peripheral insulinization is rapidly achieved (the so-called portosystemic gradient). Thus, according this hypothesis, the first phase of insulin secretion is an immediate event that prompts a significant suppression of hepatic glucose production (Luzi \& DeFronzo 1989).

Whilst PRL promotes a gain-of-function in islets during pregnancy, at the end of the gestational period islets undergo a return to the normal non-pregnant function. The increased maternal GCs, a characteristic of the late stage of gestation, have been suggested to contribute to reduced glucosestimulated insulin secretion, probably by counteracting the effect of PRL (Weinhaus et al. 2000, Shao et al. 2004). The striking correlation between STAT3 serine phosphorylation and SERCA-2 expression during the peripartum and the fact that these alterations are likely to be the result of PRL action in pancreatic $\beta$-cell prompted us to investigate whether GCs could counteract this effect. The present results show that DEX abolished PRL-induced upregulation of STAT3 serine phosphorylation without affecting STAT3 expression. This effect was companied by the abolishment of the upregulation of SERCA2 expression by PRL, in both RINm5F cells and cultured pancreatic islets. Therefore, the negative modulation of the PRL-induced augment in STAT3 serine phosphorylation and SERCA2 expression might participate in the ability of GCs to counteract the biological effects of PRL in pancreatic islets. In agreement with this proposition, it was recently described that the pre-treatment with DEX reduces the first and the second phases of insulin secretion by rat islets perfused with glucose $15 \mathrm{mM}$ (Zawalich et al. 2006). Therefore, we speculate that the downregulation of STAT3-mediated SERCA2 expression by GC might account for its ability to suppress the first phase of insulin release. The effect of GC in reducing the second phase of insulin secretion, as observed in islets from L3 rats, is probably due to a distinct mechanism.

In summary, the present study shows that STAT3 expression and serine phosphorylation are increased in pancreatic islets from pregnant rat. These events are probably due to the action of PRL and may therefore upregulate 
SERCA2 expression, contributing to the increased pancreatic $\beta$-cell response to glucose, particularly modulating the first phase of insulin secretion. Moreover, PRL-induced STAT3 serine phosphorylation and SERCA2 expression are counteracted by GCs, suggesting an intracellular mechanism by which insulin secretion returns to normal after delivery.

\section{Acknowledgements}

The authors thank Luciene M Ribeiro and Julieta S Falcão for technical assistance and Dr Nicola Conran for editing the English. We are indebted to the Drs Carla R O Carvalho and Lício A Velloso for providing part of the antibodies used in the present work.

\section{Funding}

This work was supported by the Brazilian foundations FAPESP, CAPES, and CNPQ/PRONEX. The authors declare no conflict of interest that would prejudice the impartiality of the present study.

\section{References}

Aaronson DS \& Horvath CM 2002 A road map for those who don't know JAK-STAT. Science 296 1653-1655.

Ahrén B 2005 Type 2 diabetes, insulin secretion and beta-cell mass. Current Molecular Medicine 5 275-286.

Amaral ME, Ueno M, Carvalheira JB, Carneiro EM, Velloso LA, Saad MJ \& Boschero AC 2003 Prolactin signal transduction in neonatal rat pancreatic islets and interaction with insulin signaling pathway. Hormone and Metabolic Research 35 282-289.

Amaral ME, Cunha DA, Anhê GF, Ueno M, Carneiro EM, Velloso LA, Bordin S \& Boschero AC 2004 Participation of prolactin receptors and phosphatidylinositol 3-kinase and MAP kinase pathways in the increase in pancreatic islet mass and sensitivity to glucose during pregnancy. Journal of Endocrinology 183 469-476.

Anhê GF, Torrao AS, Nogueira TC, Caperuto LC, Amaral ME, Medina MC, Azevedo-Martins AK, Carpinelli AR, Carvalho CR, Curi R et al. 2006 ERK3 associates with MAP2 and is involved in glucose-induced insulin secretion. Molecular and Cellular Endocrinology 251 33-41.

Arredouani A, Guiot Y, Jonas JC, Liu LH, Nenquin M, Pertusa JA, Rahier J, Rolland JF, Shull GE, Stevens M et al. 2002a SERCA3 ablation does not impair insulin secretion but suggests distinct roles of different sarcoendoplasmic reticulum $\mathrm{Ca}(2+)$ pumps for $\mathrm{Ca}(2+)$ homeostasis in pancreatic beta-cells. Diabetes 51 3245-3253.

Arredouani A, Henquin JC \& Gilon P $2002 b$ Contribution of the endoplasmic reticulum to the glucose-induced $[\mathrm{Ca}(2+)](\mathrm{c})$ response in mouse pancreatic islets. American Journal of Physiology. Endocrinology and Metabolism 282 E982-E991.

Beauvois MC, Merezak C, Jonas JC, Ravier MA, Henquin JC \& Gilon P 2006 Glucose-induced mixed $[\mathrm{Ca} 2+] \mathrm{c}$ oscillations in mouse beta-cells are controlled by the membrane potential and the SERCA3 Ca2 +-ATPase of the endoplasmic reticulum. American Journal of Physiology. Cell Physiology 290 C1503-C1511.

Bonner-Weir S $2001 \beta$-Cell turnover, its assessment and implications. Diabetes 50 (Suppl 1) S20-S24.

Bordin S, Boschero AC, Carneiro EM \& Atwater I 1995 Ionic mechanisms involved in the regulation of insulin secretion by muscarinic agonists. Journal of Membrane Biology 148 177-184.
Bordin S, Amaral MEC, Anhê GF, Delghingaro-Augusto V, Cunha DA, Nicoletti-Carvalho JE \& Boschero AC 2004 Prolactin-modulated gene expression profiles in pancreatic islets from adult female rats. Molecular and Cellular Endocrinology 200 41-50.

Bosqueiro JR, Carneiro EM, Bordin S \& Boschero AC 2000 Tetracaine stimulates insulin secretion through the mobilization of $\mathrm{Ca}^{2+}$ from thapsigargin- and IP3-insensitive $\mathrm{Ca}^{2+}$ reservoir in pancreatic beta-cells. Canadian Journal of Physiology and Pharmacology 78 462-468.

Brelje TC, Scharp DW, Lacy PE, Ogren L, Talamantes F, Robertson M, Friesen HG \& Sorenson RL 1993 Effect of homologous placental lactogens, prolactins, and growth hormones on islet B-cell division and insulin secretion in rat, mouse, and human islets: implication for placental lactogen regulation of islet function during pregnancy. Endocrinology 132 879-887.

Caumo A \& Luzi L 2004 First-phase insulin secretion: does it exist in real life? Considerations on shape and function American Journal of Physiology. Endocrinology and Metabolism 287 E371-E385.

Ceresa BP \& Pessin JE 1996 Insulin stimulates the serine phosphorylation of the signal transducer and activator of transcription (STAT3) isoform. Journal of Biological Chemistry 271 12121-12124.

Ceresa BP, Horvath CM \& Pessin JE 1997 Signal transducer and activator of transcription- 3 serine phosphorylation by insulin is mediated by a Ras/Raf/MEK-dependent pathway. Endocrinology 138 4131-4137.

Crepaldi SC, Carneiro EM \& Boschero AC 1997 Long-term effect of prolactin treatment on glucose-induced insulin secretion in cultured neonatal rat islets. Hormone and Metabolic Research 29 220-224.

Crepin A, Bidaux G, Vanden-Abeele F, Dewailly E, Goffin V, Prevarskaya N \& Slomianny C 2007 Prolactin stimulates prostate cell proliferation by increasing endoplasmic reticulum content due to SERCA $2 \mathrm{~b}$ overexpression. Biochemical Journal 401 49-55.

Cruz-Cruz R, Salgado A, Sánchez-Soto C, Vaca L \& Hiriart M 2005 Thapsigargin-sensitive cationic current leads to membrane depolarization, calcium entry, and insulin secretion in rat pancreatic $\beta$-cells. American Journal of Physiology. Endocrinology and Metabolism 289 E439-E445.

Cui Y, Huang L, Elefteriou F, Yang G, Shelton JM, Giles JE, Oz OK, Pourbahrami T, Lu CY, Richardson JA et al. 2004 Essential role of STAT3 in body weight and glucose homeostasis. Molecular and Cellular Biology 24 258-269.

Gorogawa S, Fujitani Y, Kaneto H, Hazama Y, Watada H, Miyamoto Y, Takeda K, Akira S, Magnuson MA, Yamasaki Y et al. 2004 Insulin secretory defects and impaired islet architecture in pancreatic beta-cell-specific STAT3 knockout mice. Biochemical and Biophysical Research Communications 319 1159-1170.

Green IC \& Taylor KW 1972 Effects of pregnancy in the rat on the size and insulin secretory response of the islets of Langerhans. Journal of Endocrinology 54 317-325.

Hubinont CJ \& Malaisse WJ 1987 Lactation-induced changes in calcium handling by rat pancreatic islets. Journal of Developmental Physiology 9 31-39.

Hubinont CJ, Dufrane SP, Garcia-Morales P, Valverde I, Sener A \& Malaisse WJ 1986 Influence of lactation upon pancreatic islet function. Endocrinology 118 687-694.

Hughes E, Lee AK \& Tse A 2006 Dominant role of sarcoendoplasmic reticulum $\mathrm{Ca}^{2+}$-ATPase pump in $\mathrm{Ca}^{2+}$ homeostasis and exocytosis in rat pancreatic beta-cells. Endocrinology 147 1396-1407.

Kawai M \& Kishi K 1999 Adaptation of pancreatic islet B-cells during the last third of pregnancy: regulation of B-cell function and proliferation by lactogenic hormones in rats. European Journal of Endocrinology 141 419-425.

Kojima H, Sasaki T, Ishitani T, Iemura S, Zhao H, Kaneko S, Kunimoto H, Natsume T, Matsumoto K \& Nakajima K 2005 STAT3 regulates Nemolike kinase by mediating its interaction with IL-6-stimulated TGFbetaactivated kinase 1 for STAT3 Ser-727 phosphorylation. PNAS 102 4524-4529.

Kulkarni RN, Roper MG, Dahlgren G, Shih DQ, Kauri LM, Peters JL, Stoffel M \& Kennedy RT 2004 Islet secretory defect in insulin receptor substrate 1 null mice is linked with reduced calcium signaling and expression of sarco(endo)plasmic reticulum $\mathrm{Ca}^{2+}$-ATPase (SERCA)-2b and -3. Diabetes 53 1517-1525. 
Kuroki M \& O’Flaherty JT 1999 Extracellular signal-regulated protein kinase (ERK)-dependent and ERK-independent pathways target STAT3 on serine-727 in human neutrophils stimulated by chemotactic factors and cytokines. Biochemical Journal 341 691-696.

Lechner J, Welte T, Tomasi JK, Bruno P, Cairns C, Gustafsson J \& Doppler W 1997 Promoter-dependent synergy between glucocorticoid receptor and Stat 5 in the activation of beta-casein gene transcription. Journal of Biological Chemistry 272 20954-20960.

Levy J, Zhu Z \& Dunbar JC 1998 The effect of glucose and calcium on $\mathrm{Ca}^{2+}$ adenosine triphosphatase in pancreatic islets isolated from a normal and a non-insulin-dependent diabetes mellitus rat model. Metabolism 47 185-189.

Lipson LG \& Sharp GW 1978 Insulin release in pregnancy: studies on adenylate cyclase, phosphodiesterase, protein kinase, and phosphoprotein phosphatase in isolated rat islets of Langerhans. Endocrinology 103 1272-1280.

Luzi L \& DeFronzo RA 1989 Effect of loss of first-phase insulin secretion on hepatic glucose production and tissue glucose disposal in humans. American Journal of Physiology. Endocrinology and Metabolism 257 E241-E246.

Marie JC, Bailbe D, Gylfe E \& Portha B 2001 Defective glucose-dependen cytosolic $\mathrm{Ca}^{2+}$ handling in islets of GK and $\mathrm{nSTZ}$ rat models of type 2 diabetes. Journal of Endocrinology 169 169-176.

Morton NM, Emilsson V, de Groot P, Pallett AL \& Cawthorne MA 1999 Leptin signalling in pancreatic islets and clonal insulin-secreting cells. Journal of Molecular Endocrinology 22 173-184.

Nasir I, Kedees MH, Ehrlich ME \& Teitelman G 2005 The role of pregnancy hormones in the regulation of $\mathrm{Pdx}-1$ expression. Molecular and Cellular Endocrinology 233 1-13.

Neilson LM, Zhu J, Xie J, Malabarba MG, Sakamoto K, Wagner KU, Kirken RA \& Rui H 2007 Coactivation of Jak1 positively modulates prolactin-Jak2 signaling in breast cancer: recruitment of ERK and Stat 3 and enhancement of Akt and Stat5a/b pathways. Molecular Endocrinology (doi: 10.1210/me.2007-0173).

Nielsen JH, Svensson C, Galsgaard ED, Moldrup A \& Billestrup N 1999 Beta cell proliferation and growth factors. Journal of Molecular Medicine 77 62-66.

O'Rourke L \& Shepherd PR 2002 Biphasic regulation of extracellular-signalregulated protein kinase by leptin in macrophages: role in regulating STAT3 Ser727 phosphorylation and DNA binding. Biochemical Journal 364 875-879.

Parsons JA, Brelje TC \& Sorenson RL 1992 Adaptation of islets of Langerhans to pregnancy: increased islet cell proliferation and insulin secretion correlates with the onset of placental lactogen secretion. Endocrinology 130 1459-1466.

Roe MW, Philipson LH, Frangakis CJ, Kuznetsov A, Mertz RJ, Lancaster ME, Spencer B, Worley JF III \& Dukes ID 1994 Defective glucose-dependent endoplasmic reticulum $\mathrm{Ca}^{2+}$ sequestration in diabetic mouse islets of Langerhans. Journal of Biological Chemistry 269 18279-18282.

Scaglia L, Cahill CJ, Finegood DT \& Bonner-Weir S 1997 Apoptosis participates in the remodeling of the endocrine pancreas in the neonatal rat. Endocrinology 138 1736-1741.

Shafrir E 1992 Animal models of non-insulin-dependent diabetes. Diabetes/Metabolism Reviews 8 179-208.
Shao J, Qiao L \& Friedman JE 2004 Prolactin, progesterone, and dexamethasone coordinately and adversely regulate glucokinase and cAMP/PDE cascades in MIN6 beta-cells. American Journal of Physiology. Endocrinology and Metabolism 286 E304-E310.

Shen Y, Schlessinger K, Zhu X, Meffre E, Quimby F, Levy DE \& Darnell JE Jr 2004 Essential role of STAT3 in postnatal survival and growth revealed by mice lacking STAT3 serine 727 phosphorylation. Molecular and Cellular Biology 24 407-419.

Sorenson RL, Brelje TC \& Roth C 1993 Effects of steroid and lactogenic hormones on islets of Langerhans: a new hypothesis for the role of pregnancy steroids in the adaptation of islets to pregnancy. Endocrinolog $\gamma \mathbf{1 3 3}$ $2227-2234$.

Stocklin E, Wissler M, Gouilleux F \& Groner B 1996 Functional interactions between Stat5 and the glucocorticoid receptor. Nature $\mathbf{3 8 3}$ 726-728.

Sun W, Snyder M, Levy DE \& Zhang JJ 2006 Regulation of Stat3 transcriptional activity by the conserved LPMSP motif for OSM and IL-6 signaling. FEBS Letters $\mathbf{5 8 0}$ 5880-5884.

Varadi A \& Rutter GA 2002 Dynamic imaging of endoplasmic reticulum $\mathrm{Ca}^{2+}$ concentration in insulin-secreting MIN6 Cells using recombinant targeted cameleons: roles of sarco(endo)plasmic reticulum $\mathrm{Ca}^{2+}$-ATPase (SERCA)-2 and ryanodine receptors. Diabetes 51 190-201.

Varadi A, Molnar E, Ostenson CG \& Ashcroft SJ 1996 Isoforms of endoplasmic reticulum $\mathrm{Ca}(2+)$-ATPase are differentially expressed in normal and diabetic islets of Langerhans. Biochemical Journal 319 521-527.

Wang MY, Koyama K, Shimabukuro M, Mangelsdorf D, Newgard CB \& Unger RH 1998 Overexpression of leptin receptors in pancreatic islets of Zucker diabetic fatty rats restores GLUT-2, glucokinase, and glucosestimulated insulin secretion. PNAS 95 11921-11926.

Weinhaus AJ, Bhagroo NV, Brelje TC \& Sorenson RL 2000 Dexamethasone counteracts the effect of prolactin on islet function: implications for islet regulation in late pregnancy. Endocrinology 141 1384-1393.

Wyszomierski SL, Yeh J \& Rosen JM 1999 Glucocorticoid receptor/signal transducer and activator of transcription 5 (STAT5) interactions enhance STAT5 activation by prolonging STAT5 DNA binding and tyrosine phosphorylation. Molecular Endocrinology 13 330-343.

Zawalich WS, Tesz GJ, Yamazaki H, Zawalich KC \& Philbrick W 2006 Dexamethasone suppresses phospholipase $\mathrm{C}$ activation and insulin secretion from isolated rat islets. Metabolism 55 35-42.

Received in final form 7 July 2007

Accepted 19 July 2007

Made available online as an Accepted Preprint

19 July 2007 
JOE 070010—4/8/2007-19:35-KARTHIA-280823—XML StyleC - pp. 1-12

\section{Author Queries}

JOB NUMBER: 070010

JOURNAL: JOE

Q1 Please provide expansions of the acronyms 'RINm5F, PDX, IDT, MEM, ASO, GLUT, SUR, MAPK and ZDF'.

Q2 Please check the sense of the sentence.

Q3 We have made a change to this sentence. Please review our edit.

Q4 We have changed the units ' $\mathrm{min} 31$ to $\min 60$ ' to 31-60 min. Please approve or provide an alternative.

Q5 Please note that the reference citation 'Crepin et al. (2006)' has been changed to 'Crepin et al. (2007)' with respect to the reference list provided.

Q6 Please provide the volume and page range details for the reference 'Neilson et al. (2007)'. 